


\section{EFFECTS OF URBANIZATION ON STREAMFLOW, SEDIMENT LOADS, AND CHANNEL MORPHOLOGY IN PHEASANT BRANCH BASIN NEAR MIDDLETON, WISCONSIN}

By

Willian R. Krug and Gerald L. Goddard

U.S. GEOLOGICAL SURVEY

Water-Resources Investigations

Report 85-4068

Prepared in cooperation with the UNIVERSITY OF WISCONSIN-EXTENSION

GEOLOGICAL AND NATURAL HISTORY SURVEY and

THE CITY OF MIDDLETON

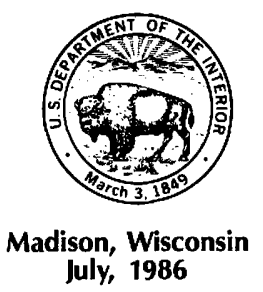




\section{UNITED STATES DEPARTMENT OF THE INTERIOR DONALD PAUL HODEL, Secretary GEOLOGICAL SURVEY \\ Dallas L. Peck, Director}

For additional information write to:

District Chief

U.S. Geological Survey, WRD

6417 Normandy Lane

Madison, Wisconsin 53719
Copies of this report can be purchased from:

Open-File Services Section

Western Distribution Branch

U.S. Geological Survey

Box 25425, Federal Center

Lakewood, Colorado 80225

(Telephone: (303) 234-5888) 


\section{CONTENTS}

Page

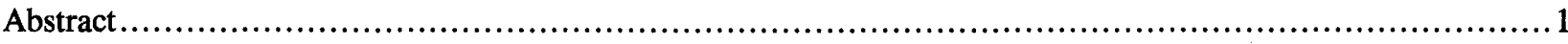

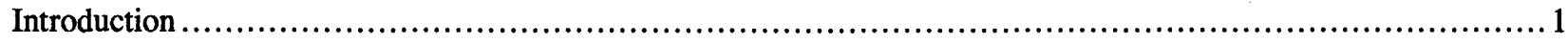

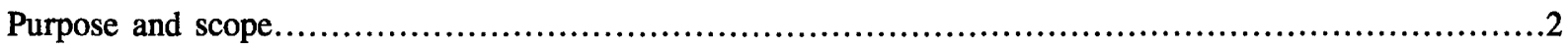

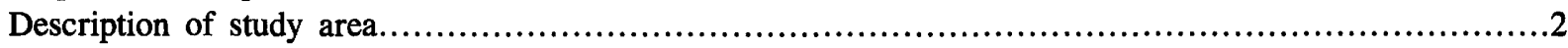

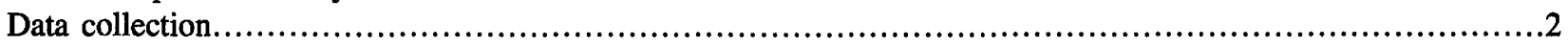

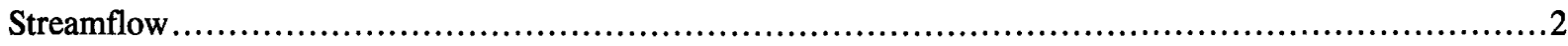

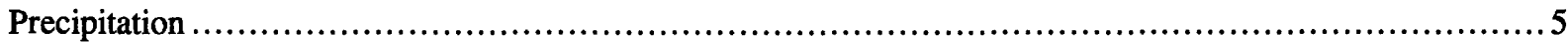

Sediment................................................................................................

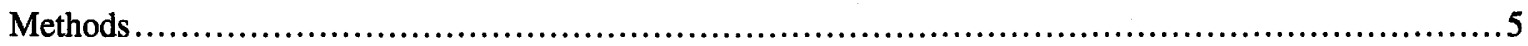

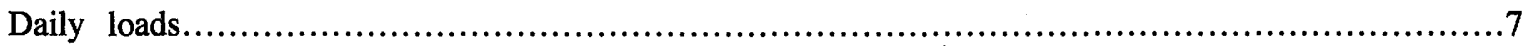

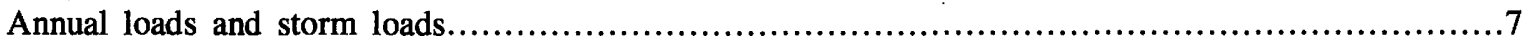

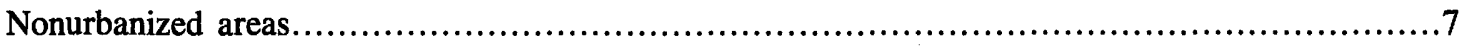

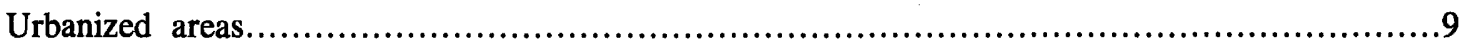

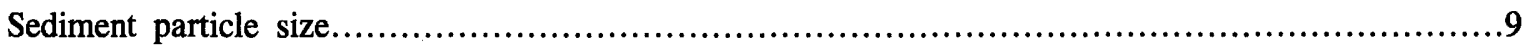

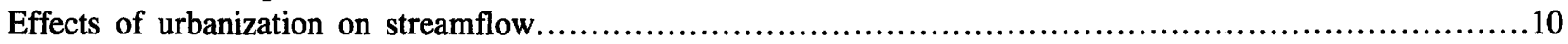

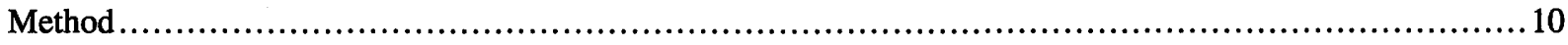

Model calibration................................................................................... 10

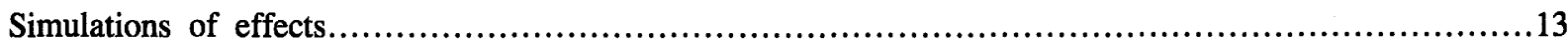

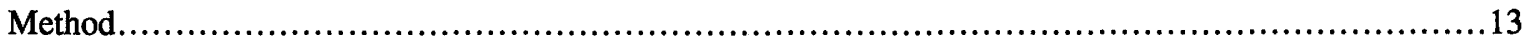

Current conditions...........................................................................

Partial urbanization.......................................................................15

Complete urbanization.......................................................................19

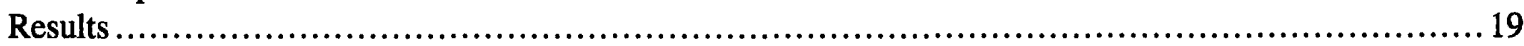

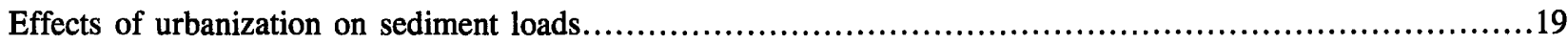

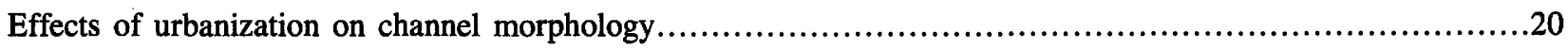

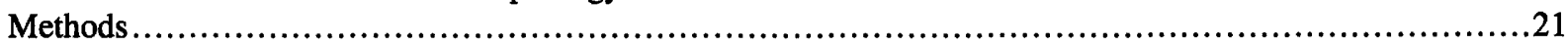

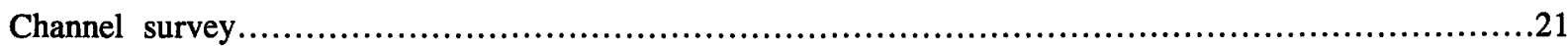

Relationship of channel morphology to sediment loads................................................21

Results.............................................................................................24

Application of model for evaluation of development alternatives...........................................25

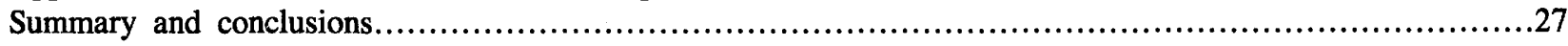

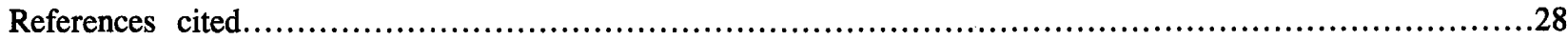

\section{ILLUSTRATIONS}

Figure 1. Map showing location of study area, gaging stations, rain gages, and channel-survey sites...........................................................................

2. Map showing location of drop structures between Century Avenue and

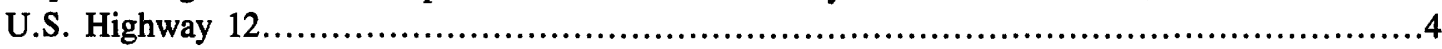

3. Graph showing comparison of daily mean discharge and daily sediment load

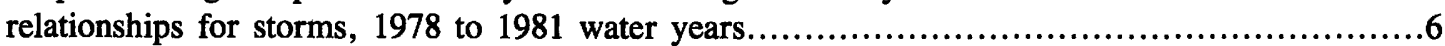

4. Graph showing cumulative monthly sediment loads, 1978 to 1981 water years...................10

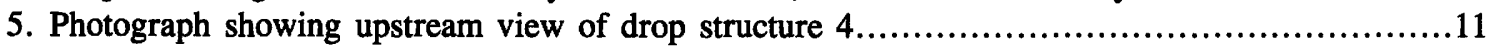

6. Photograph showing view downstream at Park Street erosion-control structure....................12

7. Box plots of percent of clay $(<0.004 \mathrm{~mm})$, silt $(0.004-0.0625 \mathrm{~mm})$, and sand

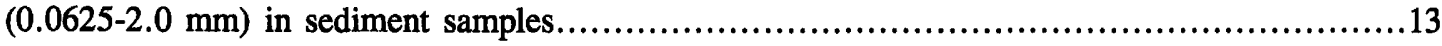

8. Map showing basin and subareas used in the rainfall-runoff model...............................14 
9-15. Graphs comparing:

9. Observed and simulated hydrographs for storm of June 25, 1978, for Pheasant Branch at Middleton, Wis. (05427948).

10. Observed and simulated hydrographs for storm of June 25, 1978, for South Fork Pheasant Branch at U.S. Highway 14 near Middleton, Wis. (05427945).

11. Observed and simulated hydrographs for storm of June 25, 1978, for North Fork Pheasant Branch at Airport Road near Middleton, Wis. (05427943).

12. Observed and simulated hydrographs for storm of September 17, 1978, for Pheasant Branch at Middleton, Wis. (05427948).

13. Observed and simulated hydrographs for storm of September 17, 1978, for South Fork Pheasant Branch at U.S. Highway 14 near Middleton, Wis. (05427945).

14. Observed and simulated hydrographs for storm of September 17, 1978, for North Fork Pheasant Branch at Airport Road near Middleton, Wis. (05427943).

15. Observed and simulated peak discharges for Pheasant Branch at Middleton,

Wis. (05427948) for nine storms used to calibrate the model........................... 18

16. Graph showing streambed profile and change in streambed elevation..........................23

17. Cross-section plot of Pheasant Branch showing erosion downstream from Century Avenue........24

18. Cross-section plot of Pheasant Branch showing channel degradation downstream

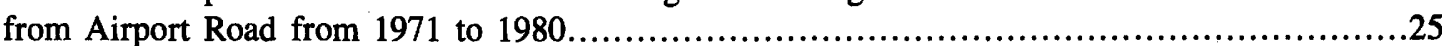

19. Cross-section plot of Pheasant Branch showing sediment deposition upstream from Park Street.

20. Cross-section plot showing sediment deposition in Pheasant Branch marsh from 1977 to 1981

21-38. Graphs showing comparison of approximate 2-, 5-, 10-, and 25-year hydrographs for subbasins in the Pheasant Branch drainage basin.

\section{TABLES}

Table 1. Gaging stations in the Pheasant Branch basin and their drainage areas, and minimum, mean, and maximum discharges

Comparison of total precipitation for April-October at U.S. Highway 12 with

Truax Field at Madison and departure from normal.

. Comparisons of sediment load, 1978-81.

4. Comparison of winter sediment loads between Pheasant Branch at Century Avenue and Pheasant Branch at mouth.

5. Magnitude of flood peaks at selected recurrence intervals for three simulated conditions at three sites.

6. Change in mean stream-channel properties between 1971 and 1981.

7. Percent increase of 2-year flood, bankfull width and bankfull depth from present conditions to urbanized conditions. 


\section{CONVERSION TABLE}

For readers who prefer metric (International Systems) units, inch-pound units in this report may be converted by the following factors:

Multiply inch-pound unit

inch (in.)

foot (ft)

mile (mi)

square foot $\left(\mathrm{ft}^{2}\right)$

acre

square mile $\left(\mathrm{mi}^{2}\right)$

cubic foot $\left(\mathrm{ft}^{3}\right)$

cubic yard $\left(\mathrm{yd}^{3}\right)$

acre-feet

foot per second ( $\mathrm{ft} / \mathrm{s})$

cubic foot per second $\left(\mathrm{ft}^{3} / \mathrm{s}\right)$

pound (lb)

ton, short

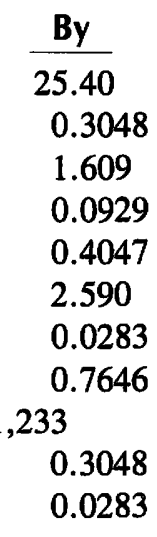

453.5

0.9072
To obtain metric unit

millimeter (mm)

meter (m)

kilometer (km)

square meter $\left(\mathrm{m}^{2}\right)$

hectare (ha)

square kilometer $\left(\mathrm{km}^{2}\right)$

cubic meter $\left(\mathrm{m}^{3}\right)$

cubic meter $\left(\mathrm{m}^{3}\right)$

cubic meter $\left(\mathrm{m}^{3}\right)$

meter per second $(\mathrm{m} / \mathrm{s})$

cubic meter per second

$\left(\mathrm{m}^{3 / \mathrm{s}}\right)$

gram $(\mathrm{g})$

megagram $(\mathrm{Mg})$ 


\title{
EFFECTS OF URBANIZATION ON STREAMFLOW, SEDIMENT LOADS, AND CHANNEL MORPHOLOGY IN PHEASANT BRANCH BASIN NEAR MIDDLETON, WISCONSIN
}

\author{
By William R. Krug and Gerald L. Goddard
}

\section{ABSTRACT}

A 5-year, data-collection and modeling study was conducted on Pheasant Branch basin in and near Middleton, Wisconsin. The objectives of the study were to: (1) describe the streamflow characteristics, sediment transport, and stream-channel morphology in the Pheasant Branch basin; and (2) relate the above factors to changes caused by urbanization and project the effect of urbanization on the hydrology and channel morphology of the study area.

Streamflow data were collected at five sites for 4 years in the basin to define present streamflow conditions. Suspended-sediment data also were collected at these sites. In addition, periodic surveys of monumented channel cross sections were made and compared with a survey from an earlier study to document changes in the channel over a period of 10 years.

The suspended-sediment data show a decrease in suspended-sediment load through the fully urbanized reach of the stream in 3 of the 4 years studied. This corresponds with the slight net decrease in cross-section area in this reach for the same period. Possible explanations for the decrease in suspended-sediment loads through this reach include (1) sediment being trapped at the five drop structures and the Park Street erosion-control structure and (2) sediment being deposited in overbank areas throughout the reach. Farther downstream, the suspended-sediment load decreased through the Pheasant Branch marsh during a year of high flow but increased through the marsh in 2 of the 3 years for which complete data are available. The marsh is not acting as a net sediment trap in some years.

A rainfall-runoff model was calibrated and verified for the basin upstream from U.S. Highway 12. This model was used to simulate 68 years of summer flood hydrographs for three conditions: Current land use, projected urban development, and complete urban development of all lands in the basin. Analysis of simulated flood flows indicates that projected urban development would double the mean annual flood peaks at U.S. Highway 12. Complete development of the basin would increase the mean annual flood peak by a factor of 2.4 .

From 1971 to 1977 , the mean streambed elevation lowered by almost 2 feet, and the mean channel width increased by more than 35 percent in the reach downstream from the fully urbanized part of the basin. In other reaches, the mean streambed elevation lowered by more than a foot. Changes in channel cross sections after 1977 were smaller.

Increases in flood flow would tend to enlarge the channel. An increase in the mean annual flood by a factor of 2.0 to 2.4 will cause a 40 to 50 percent increase in channel width and a 30 to 40 percent increase in channel depth.

\section{INTRODUCTION}

Pheasant Branch (fig. 1) is a tributary to Lake Mendota, located in Dane County in south-central Wisconsin. The stream drains an area of $24.5 \mathrm{mi}^{2}$ that consists of rolling hills in the upland, heavily cultivated fields in the flood plains, significant areas of residential, commercial, and light industrial development, and a marsh area at the mouth. Urbanization of the basin is increasing rapidly and is expected to continue. The population of Middleton has increased from 8,246 in 1970 to 11,851 in 1980 -a 44 percent increase. Projections for the year 2000 indicate a potential urban population of 18,000 (City of Middleton, 1982).

Problems of stream-channel erosion and suspended sediment have developed in Pheasant Branch because of land-use changes in the drainage basin. 
During the 1976-77 monitoring period for preparation of the Dane County Water Quality Plan, Pheasant Branch at U.S. Highway 12 had the highest suspendedsediment load per unit area of all rural streams monitored in Dane County (Lathrop \& Johnson, Dane County Regional Planning Commission, 1979). This high suspended-sediment load from nonpoint sources was a factor in the selection of the Pheasant Branch basin as a priority watershed to receive State funding for pollution abatement measures. Significant amounts of sediment are carried into Lake Mendota, where dredging is required to maintain recreational boating near the mouth.

The city of Middleton has expended considerable effort in reducing the erosion of the streambed and banks. Since 1980 they have spent more than $\$ 95,000$ on engineering studies and erosion-control structures. Increased runoff from urban development in the basin probably would make erosion problems worse. A preliminary report (Grant and Goddard, 1980) evaluated the channel erosion and sediment data collected during the first year of this study and documented historical erosion problems.

\section{PURPOSE AND SCOPE}

Specifically the report describes (1) the streamflow characteristics, sediment transport, and stream-channel morphology in the Pheasant Branch basin; (2) the use and results of a rainfall-runoff model that projected the effect of urbanization on the hydrology of the study area; (3) the estimated effects that changes in hydrology projected by the model will have on channel morphology; and (4) the use of the rainfall-runoff model to simulate storm hydrographs by subbasin for use by city engineers or planners.

Streamflow, sediment, channel geometry, and precipitation data were collected during 1977-81 to evaluate channel erosion and sedimentation in the basin. Locations of the sampling sites are shown in figure 1. Continuous streamflow records were obtained at five gaging stations; suspended-sediment samples were collected by automatic samplers at four of the gaging stations; surveys of channel cross sections were made for another study in 1971 (Lawrence and Holmstrom, 1972) and repeated for this study in 1977, 1979, 1980, and 1981. Precipitation was recorded at three sites.

This study was conducted in cooperation with the city of Middleton and the University of WisconsinExtension Geological and Natural History Survey. Data used in this study came from four streamflow and sediment gaging stations funded by the U.S. Army Corps of Engineers, and from streamflow and sediment gaging stations and rain gages funded by the Dane County Regional Planning Commission as parts of other projects. This report describes the results of the study.

\section{DESCRIPTION OF THE STUDY AREA}

Pheasant Branch (fig. 1) has two principal branches-the North Fork and the South Fork. The South Fork drains an area of steep hills. The agricultural areas in this part of the basin are being replaced by urban development. The North Fork basin has steep hills in the headwaters and extensive flat areas farther downstream. In the flatter areas, the stream channels have been straightened and dredged for agricultural drainage.

Downstream from the confluence of the two forks, Pheasant Branch flows through the city of Middleton. This part of the stream is steeper than the reach upstream. The stream is actively eroding the streambanks in this urban reach. Five drop structures (fig. 2) have been installed in this reach to reduce the effective slope.

Downstream from the urban reach, the stream flows through Pheasant Branch Marsh. Sometime in the 1950 's the stream took a new channel, by-passing the marsh, flowing directly to Lake Mendota. The channel was rerouted back through the marsh in 1971. The stream now follows this re-created channel into the marsh and then follows a natural channel out of the marsh into Lake Mendota.

The soils in the Pheasant Branch basin are mostly silt loams or mucks. They are moderately deep to deep soils, ranging from well drained to poorly drained. Most of the soils are highly erodible, especially in the steep, urban reach.

\section{DATA COLLECTION STREAMFLOW}

Five gaging stations were installed in the Pheasant Branch basin during the summer and fall of 1977 to provide continuous streamflow records. Locations of these gaging stations are shown in figure 1 . Table 1 summarizes their drainage areas and discharges. The Airport Road (05427943), South Fork (05427945), and U.S. Highway 12 (05427948) gages monitor rural runoff; the Century Avenue (05427950) and stream mouth (05427952) gages monitor urban runoff and the effect of Pheasant Branch marsh on reduction of peak flow and trapping of suspended sediment. Daily mean streamflow data for the five gaging stations have been published separately (U.S. Geological Survey 1978, $1979,1980,1981)$. Discharge at the mouth of Pheasant Branch is affected by variable backwater from Lake Mendota. Therefore, an unsteady flow model (Lai and Onions, 1976) was used to compute the discharge from stages recorded at two sites $900 \mathrm{ft}$ apart along the channel. Stable stage-discharge relations existed at all of the other gaging-station sites. 


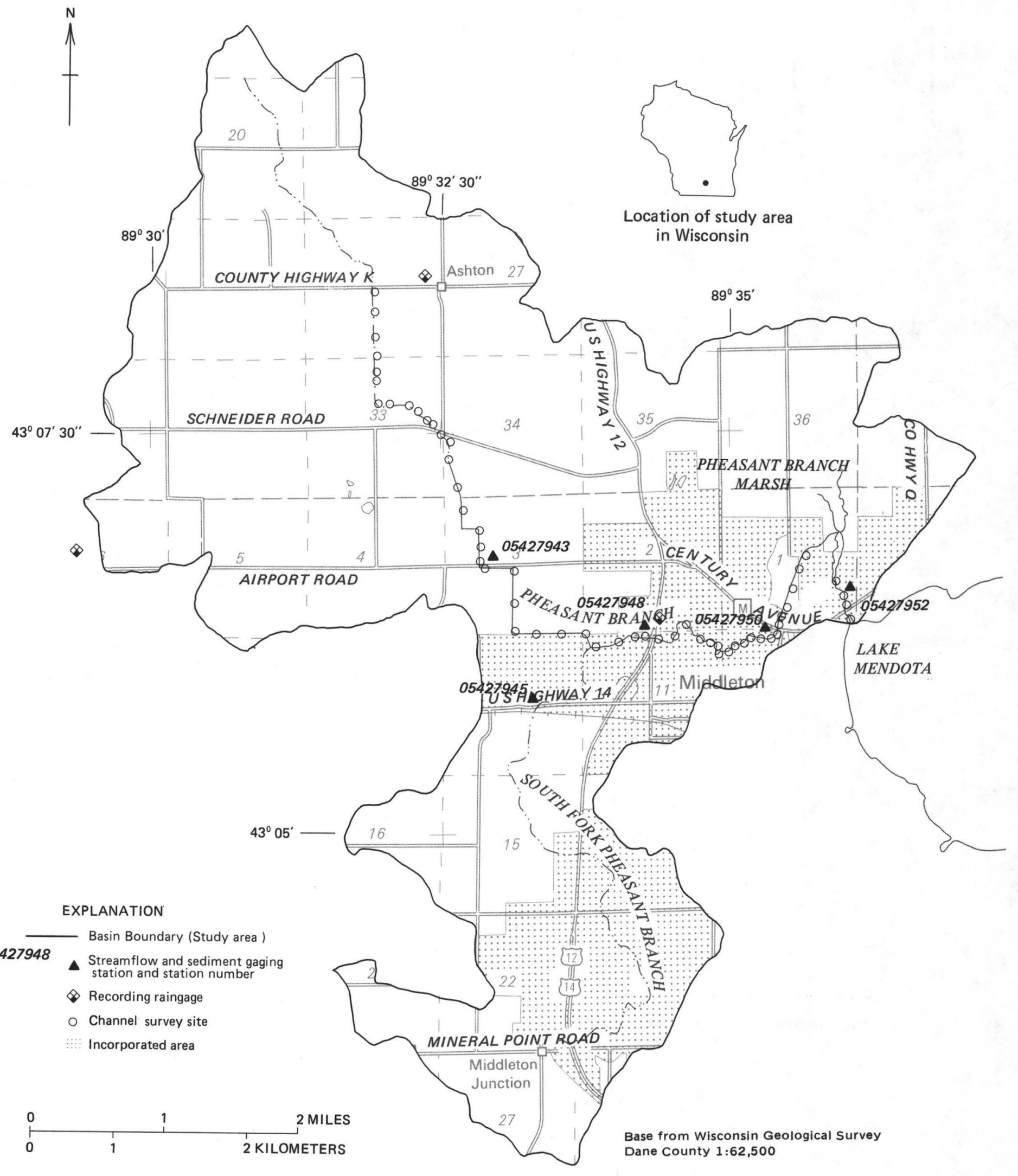

Figure 1. Location of study area, gaging stations, rain gages, and channel-survey sites. 


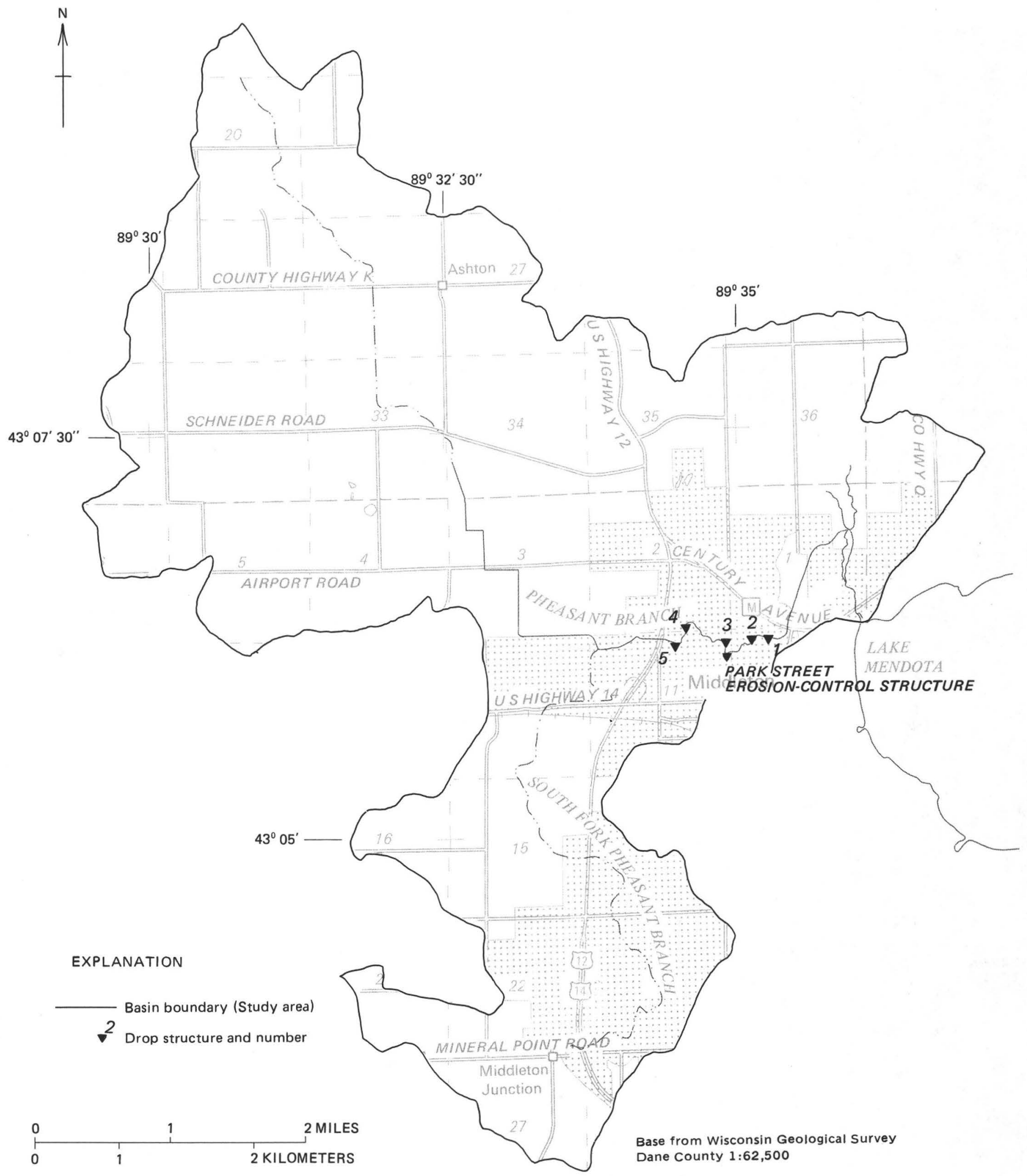

Figure 2. Location of drop structures between Century Avenue and U.S. Highway 12. 


\section{PRECIPITATION}

Precipitation amounts were recorded at three sites, as shown in figure 1. The rain gages near Ashton and along Airport Road were Belfort recording weighingbucket rain gages serviced by local observers. The rain gage at the U.S. Highway 12 gaging station recorded precipitation at 15-minute intervals. Table 2 compares precipitation recorded during nonwinter periods and departure from normal for the Madison National Weather Service station at Truax Field (Environmental Data and Information Service 1978, 1979, 1980, 1981) with precipitation recorded at the U.S. Highway 12 gaging station. Precipitation was recorded at the U.S. Highway 12 gaging station for April to October for each year.

\section{SEDIMENT}

Suspended sediment was monitored at five gaging stations in the basin (fig. 1). Suspended sediment is sediment maintained in suspension by the turbulence of the water. Bedload, material moving on or near the stream bottom, was not measured. The sediment moving in Pheasant Branch is nearly all fine enough to be moved in suspension, so bedload is a very small part of total load. Suspended sediment will be called sediment in the rest of this report because the suspended sediment measured at the gaging stations is very nearly total sediment.

\section{Methods}

Stage-activated automatic point samplers were used at four of the stations to collect samples of storm runoff. ISCO model 1680 samplers $^{1}$ were used at the South Fork, U.S. Highway 12, and mouth sites, and a U.S. PS-69 sampler was used at Century Avenue. To ensure that the automatic samplers collected representative samples of the stream cross section, simultaneous equal-width increment (EWI) samples (Guy and Norman, 1970) were also collected over a range of stream discharge. A consistent relationship between the sampler-point concentration and the average crosssection concentration existed at each site. These relationships remained fairly constant during the study. There was no automatic sampler at Airport Road. EWI samples were collected when possible during runoff and during base flow.

Sediment loads for the 1978 to 1981 water years were computed using the sediment concentrations of the collected samples. Many more sediment samples of storm runoff were collected because sediment concentration varies with changing discharge. All sediment loads were computed by the integration method described by Porterfield (1972). All sediment data have been published in the U.S. Geological Survey's 1978 to 1981 annual data reports.

${ }^{1}$ The use of brand names in this report is for identification purposes only and does not imply endorsement by the U.S. Geological Survey.

Table 1. Gaging stations in the Pheasant Branch basin and their drainage areas, and minimum, mean, and maximum discharge

\begin{tabular}{|c|c|c|c|c|c|}
\hline \multirow[b]{2}{*}{$\begin{array}{l}\text { Station } \\
\text { number } \\
\end{array}$} & \multirow[b]{2}{*}{ Station name ${ }^{1}$} & \multirow[b]{2}{*}{$\begin{array}{c}\text { Drainage area } \\
\left(\mathbf{m i}^{\mathbf{2}}\right)\end{array}$} & \multicolumn{3}{|c|}{ Recorded discharge, water years $1978-81\left(\mathrm{ft}^{3} / \mathrm{s}\right)$} \\
\hline & & & $\begin{array}{c}\text { Minimum } \\
\text { instantaneous }\end{array}$ & Mean & $\begin{array}{c}\text { Maximum } \\
\text { instantaneous }\end{array}$ \\
\hline 05427943 & $\begin{array}{l}\text { Pheasant Branch at } \\
\text { Airport Road near } \\
\text { Middleton, Wis. }\end{array}$ & 9.62 & 0.22 & 1.83 & 414 \\
\hline 05427945 & $\begin{array}{l}\text { South Fork Pheasant } \\
\text { Branch at Highway } 14 \\
\text { near Middleton, Wis. }\end{array}$ & 25.74 & 0 & .47 & 200 \\
\hline 05427948 & $\begin{array}{l}\text { Pheasant Branch at } \\
\text { Middleton, Wis. (U.S. } \\
\text { Highway 12) }\end{array}$ & ${ }^{2} 18.3$ & .29 & 3.88 & 479 \\
\hline 05427950 & $\begin{array}{l}\text { Pheasant Branch at } \\
\text { Century Avenue at } \\
\text { Middleton, Wis. }\end{array}$ & 220.8 & .36 & 4.11 & 483 \\
\hline 05427952 & $\begin{array}{l}\text { Pheasant Branch at } \\
\text { mouth at Middleton, } \\
\text { Wis. }\end{array}$ & 224.5 & 2.4 & 11.1 & 437 \\
\hline
\end{tabular}

${ }^{1}$ Italicized part of the name is used in text of report unless the complete name is required for clarity.

$21.22 \mathrm{mi}^{2}$ of the drainage area does not contribute to surface runoff. 
Table 2. Comparison of total precipitation for April-October at U.S. Highway 12 with Truax Field at Madison and departure from normal

Total precipitation (in.)

\begin{tabular}{ccccc} 
Water year $^{\mathbf{1}}$ & U. S. Highway 12 & Truax Field & Departure from normal & $\begin{array}{c}\text { Number of storms } \\
\text { exceeding } \mathbf{1} \text { inch }\end{array}$ \\
\hline 1978 & 31.90 & 30.43 & +7.65 & 9 \\
1979 & 18.27 & 16.67 & -6.11 & 5 \\
1980 & 29.21 & 30.97 & +8.19 & 7 \\
1981 & 24.75 & 25.15 & +2.37 & 4 \\
\hline
\end{tabular}

${ }^{1}$ For both stations, the precipitation totals for each year are for the months of October of the previous calendar year and April to September.

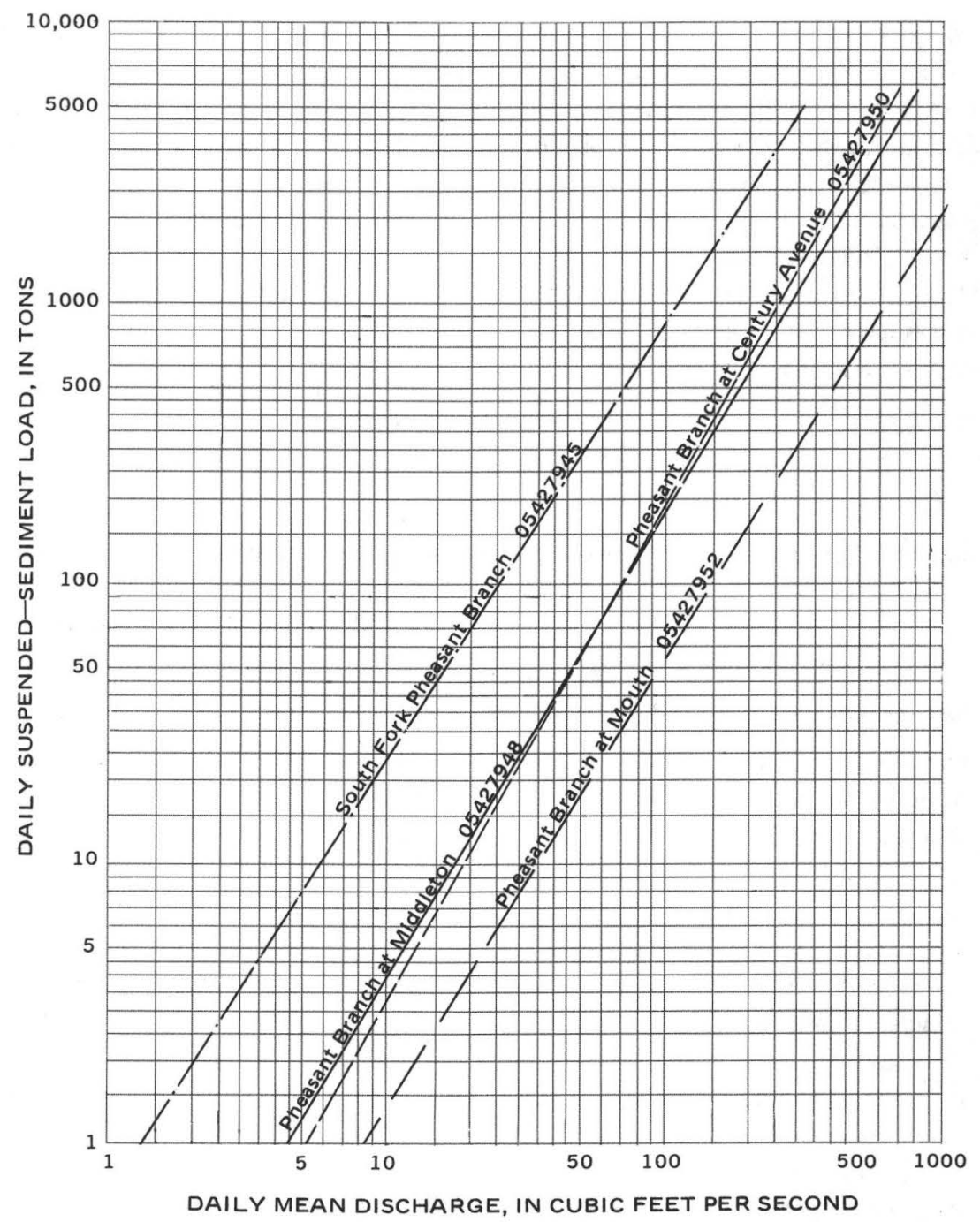

Figure 3. Comparison of daily mean discharge and daily sediment load relationships for storms, 1978 to 1981 water years. 


\section{Daily Loads}

The sediment carrying characteristics of the stream can be seen in figure 3, which compares relationships between daily discharge and daily sediment loads, at the various gaging stations. For example, at a daily discharge of $100 \mathrm{ft}^{3} / \mathrm{s}$, the daily sediment load would be expected to be about 850 tons at the South Fork station, about 180 tons at the U.S. Highway 12 station, about 200 tons at the Century Avenue station, and about 55 tons at the mouth station. The South Fork station has the highest sediment loads at all flows. The U.S. Highway 12 and Century Avenue station have similar sediment loads, with the U.S. Highway 12 station having slightly higher sediment loads at high flows and slightly lower sediment loads at low flows. The mouth station has the lowest sediment loads at all flows.

\section{Annual Loads and Storm Loads}

Storm and annual sediment loads are summarized in table 3 for the period of data collection at each station. As shown, the annual sediment loads are highly variable from year to year and are greatly influenced by the number, magnitude, coverage, and intensity of rainstorms during the year. To illustrate this variability, annual sediment loads for the Century Avenue station are summarized below, along with departures from normal precipitation.

\begin{tabular}{lcc} 
Water year & 1978 & 1979 \\
\hline Sediment load (tons) & 6,363 & 519 \\
$\begin{array}{l}\text { Departures from normal } \\
\text { precipitation (in.) }\end{array}$ & +6.29 & -3.76 \\
for water year & & \\
& 1980 & 1981 \\
\hline $\begin{array}{l}\text { Sediment load (tons) } \\
\text { Departures from normal }\end{array}$ & 1,080 & 2,241 \\
$\quad$ precipitation (in.) & +7.05 & +1.55 \\
for water year & & \\
\end{tabular}

Storm intensity is more important than annual precipitation in determining sediment load. For example, precipitation during water year 1980 was the greatest of the 4 years, but sediment load was third greatest because the 1980 precipitation came in many small-to medium-sized storms. Precipitation during water year 1978 was slightly less than in 1980 , but the sediment load was about 6 times greater than 1980. The sediment load associated with three intense storms acounted for about 80 percent of the annual load in 1978. Storm runoff accounted for 82 to 99 percent of the annual suspended-sediment load at the Century Avenue station during the study period.

\section{Nonurbanized areas}

Sediment loads at the South Fork station are relatively high compared to the other sites. The annual sediment loads were $2,988,360,558$, and 348 tons in the $1978,1979,1980$, and 1981 water years, respectively, compared to $6,413,608,1,103$, and 1,776 tons at the U.S. Highway 12 station for the same years. The South Fork sediment yields were 521, 62.7, 97.2, and 60.7 tons $/ \mathrm{mi}^{2}$ and the sediment yields at U.S. Highway 12 were $350,33.2,60.3$, and 97.0 tons $/ \mathrm{mi}^{2}$ for the same respective years. The large storm of August 31-September 3, 1981, accounted for the higher yield at the U.S. Highway 12 site for the 1981 water year. Precipitation from this storm was confined mainly to the northern part of the basin with only light precipitation in the South Fork basin.

The headwaters area of the South Fork basin has steeper overland slopes than the rest of the Pheasant Branch basin. When row crops are planted on these steeper slopes erosion can take place much easier, resulting in higher sediment yields. This basin is in the rapidly urbanizing area of southwest Madison and western Middleton. Construction site runoff may account for the higher yields in the basin. The highest sediment concentrations were observed at this station. The maximum sediment concentration observed was 18,400 $\mathrm{mg} / \mathrm{L}$ compared to a maximum observed sediment concentration of $8,980 \mathrm{mg} / \mathrm{L}$ at the Century Avenue station.

At the Airport Road station, which did not have an automatic sampler, instantaneous EWI sediment samples were collected from June 1977 to September 1981. These samples were taken over a range in discharge from 0.13 to $268 \mathrm{ft}^{3} / \mathrm{s}$. Observed sediment concentrations ranged from 4 to $2,520 \mathrm{mg} / \mathrm{L}$, and instantaneous sediment discharges ranged from 0.01 to 868 ton/d. An instantaneous discharge versus instantaneous concentration relationship was developed based on these samples and used to estimate storm sediment loads for this station. Estimated annual sediment loads from this basin were the lowest compared to the other basins. Estimated annual loads were 774, 123, 248, and 535 tons for the 1978, 1979, 1980, and 1981 water years, respectively, with corresponding estimated annual sediment yields of $80.5,12.8,25.8$, and 55.6 tons $/ \mathrm{mi}^{2}$. The land use in this basin is primarily agricultural, but small residential areas are beginning to develop.

The intervening subarea of $2.94 \mathrm{mi}^{2}$ upstream from the U.S. Highway 12 and downstream from the South Fork and Airport Road stations is also a source of relatively high sediment loads. Land use is primarily agricultural, but an industrial park is also located in this subarea. Overland slopes are very flat. Estimated storm sediment loads were $2,600,110,260$, and 870 tons and estimated sediment yields were $900,42,100$, and 300 
Table 3. Comparisons of sediment loads, 1978-81

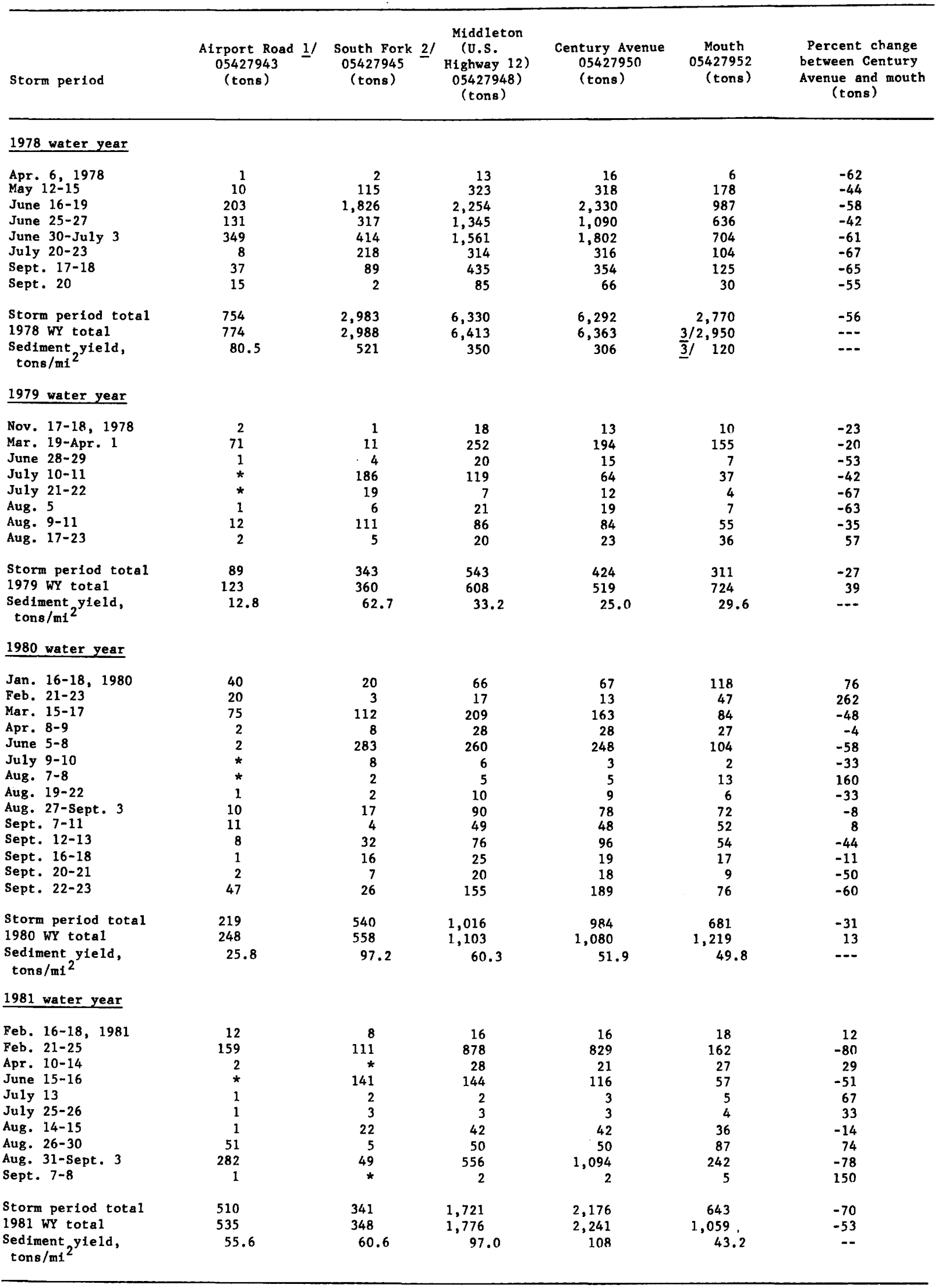

$1 /$ Sediment loads estimated using instantaneous discharge versus instantaneous concentration relationship. $\overline{2} / 1978$ water year sediment loads estimated using daily mean discharge versus dafly load relationship.

$\overline{3} /$ For period April to September 1978 on 1y.

* Sediment load is less than 1 ton. 
tons $/ \mathrm{mi}^{2}$ for the $1978,1979,1980$, and 1981 water years, respectively. These loads are the difference between the storm sediment load at the U.S. Highway 12 station and the sum of the storm sediment loads at the South Fork and Airport Road stations. During the 1978 to 1981 water years, this subarea contributed about 20 to 50 percent of the total storm sediment load at the U.S. Highway 12 station.

\section{Urbanized areas}

Comparison of the cumulative sediment loads between the U.S. Highway 12 and Century Avenue stations shows that sediment loads were slightly higher at the U.S. Highway 12 station until the last month of the study, when one large storm accounted for a large increase in sediment load at the Century Avenue station. However, for some individual storms, there was a reduction in sediment loads between the U.S. Highway 12 and Century Avenue stations while for others there was an increase. Figure 4 illustrates these points. The cumulative monthly sediment load for each station during the study period is plotted. The difference between the lines shows the amount of sediment trapped or removed from a reach. Comparing the lines for the U.S. Highway 12 and Century Avenue stations shows the amount of sediment deposited or trapped within this reach. This reach of Pheasant Branch passes through the urban part of the drainage basin and shows signs of active streambank erosion. Despite the appearance of erosion, there is no significant difference in sediment loads between these two stations except for the one large storm in 1981. The reasons for this are unclear. Possible explanations include (1) sediment being trapped at five drop structures (figs. 2 and 5) in this reach and the erosion-control structure at Park Street (fig. 6), and (2) sediment being deposited in overbank areas throughout the reach.

A comparison of sediment loads between Century Avenue and the mouth for storm events indicates significant deposition in the marsh. For the 1978, 1979, 1980, and 1981 water years there were decreases of 56, 26, 31 , and 70 percent, respectively. For some large storms, the sediment load was reduced by as much as 80 percent. Figure 4 shows that about 4,000 tons of sediment were deposited in the Pheasant Branch marsh from 1978 to 1981. Most of the sediment was trapped during storm events as is shown in table 3. To get an idea of the magnitude of sediment deposition in the marsh, the 4,000 tons of trapped sediment might be visualized as a cube about $48 \mathrm{ft}$ on each side assuming 1 ton of sediment equals $1 \mathrm{yd}^{3}$.

A comparison of the annual sediment loads between Century Avenue and the mouth for the 1979 to 1981 water years shows an increase in loads through the marsh for 2 of the 3 years. The annual sediment load increased 39 and 13 percent in the 1979 and 1980 water years, respectively, and decreased 53 percent in the 1981 water year. This suggests that the marsh merely detains some of the sediment and releases it later to Lake Mendota. This is illustrated by the comparison of fall and winter low-flow sediment loads between Century Avenue and the mouth for the 1979 to 1981 water years as shown in table 4 . The sediment load increased through this reach by 189,298 , and 306 tons during the fall and winter months for the 1979,1980 , and 1981 water years, respectively.

Water leaving the marsh was noticeably turbid during the fall; this was probably caused by the drawdown of Lake Mendota to its winter level. The reach of Pheasant Branch at its mouth and much of Pheasant Branch marsh is affected by backwater from the lake from about April to October. As the lake is lowered during November, the water-surface slope increases through the marsh and this reach of Pheasant Branch. The stream velocity also increases as the slope increases. The increased stream velocity along with the reduction in vegetation resuspends much of the sediment and moves it into the lake. Some of the sediment trapped in the marsh from prior large storms was merely temporarily detained.

The effect of the marsh on sediment varies with the time of year and the intensity of storms. Sediment is trapped in the marsh during storms. Some of this sediment is apparently resuspended and removed from the marsh during fall and winter. It appears likely that sediment from smaller storms settles in the channels in the marsh during high-water periods and it is later removed as velocities increase as the water level falls. Sediment from large storms appears to be deposited in areas of the marsh outside of the stream channels, where it is less likely to be removed.

\section{Sediment Particle Size}

Suspended-sediment particle-size data collected during the study are summarized in figure 7. These EWI samples were collected during various storms over a wide range in discharge to identify the size of sediment being transported from each basin. Most of the material collected in these samples was in the clay-silt range (0.00024 to $0.062 \mathrm{~mm}$ ). Sand particles $(0.062$ to 2.0 $\mathrm{mm}$ ) accounted for a relatively small amount of material for most of the samples.

Nearly all the sediment being transported from the nonurbanized Airport Road and South Fork basins was in the silt/clay range. Small amounts of sediment in the sand range showed up farther downstream at the U.S. Highway 12 site. Slightly higher amounts of sand were present at the Century Avenue site at the downstream end of the urbanized part of the basin. At the mouth, 


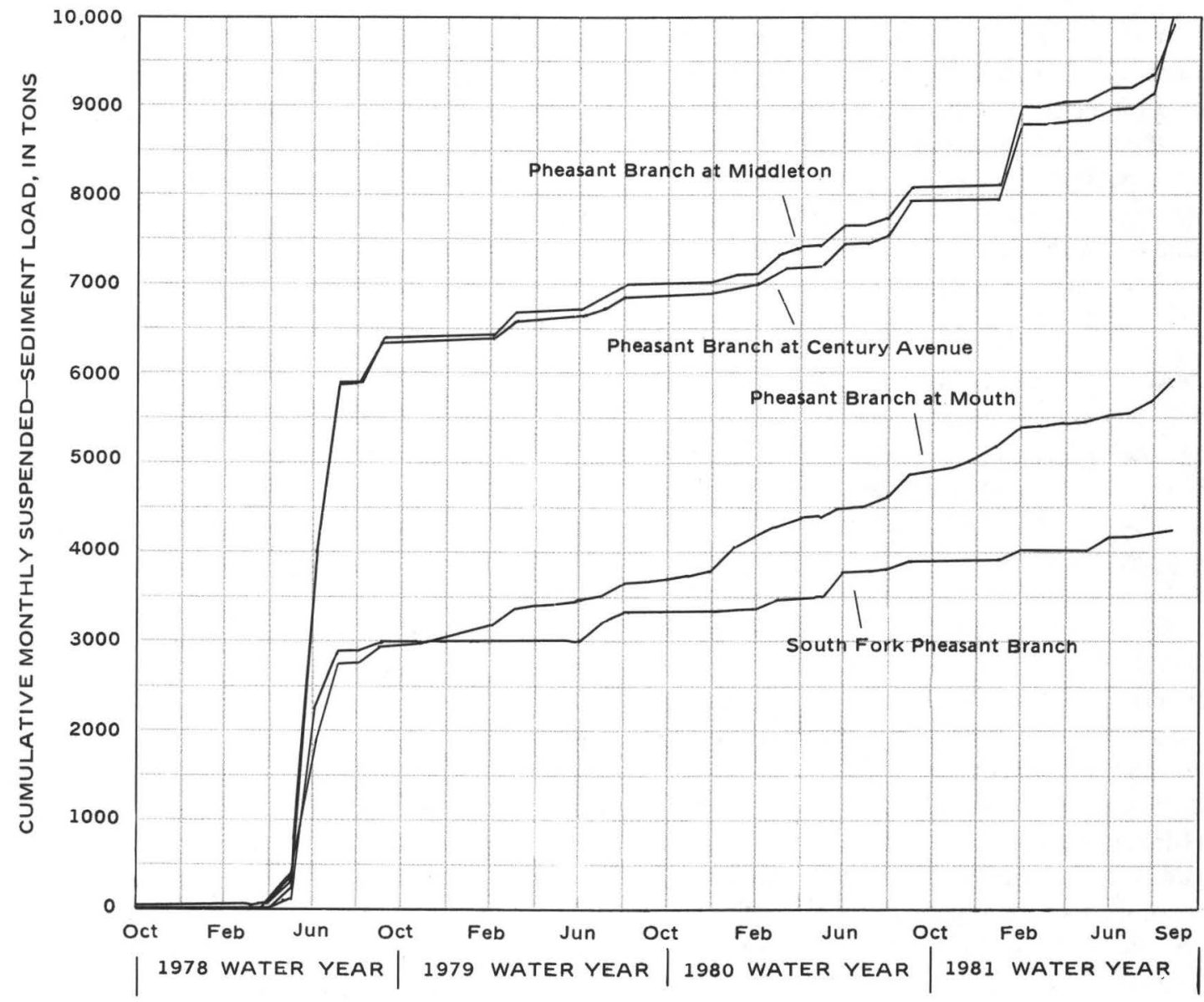

Figure 4. Cumulative monthly sediment loads, 1978 to 1981 water years.

small amounts of sand were also sampled, but most of the sediment was in the silt/clay range as it was at the other sites.

\section{EFFECTS OF URBANIZATION ON STREAMFLOW}

A precipitation-runoff model was used to determine the increase in flood peaks that would result from partial and complete urbanization of the basin and to provide a means to predict the hydrologic effects of detailed development plans for part or all of the drainage basin. The U.S. Geological Survey Distributed Routing Rainfall-Runoff Model (DR3M) (Alley and Smith, 1982) was selected for this study because it has the capabilities required to meet these goals. The important capabilities include the ability to subdivide the basin into smaller units and treat infiltration and runoff differently in different areas; the ability to route overland and channel flow; and the ability to simulate water storage in detention ponds, overbank areas, or upstream from culverts.

\section{METHOD}

The model was used to simulate storm runoff from the basin upstream from the gaging station at U.S. Highway 12 (fig. 1). This station and drainage basin were selected because the basin includes most of the area that is subject to development. Most of the area downstream from U.S. Highway 12 is already developed and is not expected to change significantly in the foreseeable future. Selection of this basin limited the number of subdivisions of the basin to a manageable number.

The basin was initially subdivided into 59 small, hydrologically homogenous subdivisions, called subareas, and their connecting channels. For each subarea the area, length, slope, percentage of impervious area, and soil type were determined. The area, length, and slope were measured on U.S. Geological Survey quadrangles. The impervious area for areas with significant development was determined from topographic maps at a scale of $1^{\prime \prime}=100^{\prime}$. Soil types and hydraulic characteristics were taken from a report by Clocker and Patzer (1978).

\section{MODEL CALIBRATION}

The data used for calibration of the model were collected at the Airport Road, South Fork, and U.S. Highway 12 gaging stations and at the three rain gages shown in figure 1 . Nine storms were selected to use in 
calibration. These storms represented an adequate range in amounts of precipitation and there was sufficient corresponding streamflow and precipitation data available for all of the storms.

The model includes several parameters that represent physical characteristics or processes in the basin. These are estimated initially from measurable physical characteristics or from published estimates. They are later refined during calibration. Six of these parameters influence soil moisture accounting and infiltration, including a pan evaporation coefficient and several values related to the hydraulic conductivity of the soil and the changes in hydraulic conductivity with moisture content. Two other parameters describe the relationship between depth of water and flow. More detail on these parameters is provided in the model user's manual (Alley and Smith, 1982).

Calibration consisted of running the model repeatedly, each time with some parameters changed, until the simulated runoff compared favorably with actual runoff for the same storm. Some of this calibration was accomplished using the optimization features of the model to automatically adjust certain parameters and determine the set of parameters that resulted in the best simulation. The rest of the calibration was accomplished by adjusting the basin characteristics in the model to improve the simulation.

The optimization component of the model adjusts a set of parameters relating to soil-moisture and rainfallexcess computations. These parameters control the total volume of runoff for any storm. Therefore, the automatic optimization is done without any routing through the channel network or computation of a runoff hydrograph. This stage of calibration is used only for the volume of runoff, without reference to its timing.

The next stage of calibration involved adjustment of the subdivision of the basin. First, small, similar, adjacent subareas were combined into larger subareas to save computer time and expense. This process continued as long as the recombination of areas did not significantly affect the results. A few larger areas were divided into smaller areas to better represent the basin, especially to separate areas expected to be developed differently. The final result was the 32 subareas connected by 16 channels shown in figure 8 .

A third stage in calibration involved adjustment of the parameters affecting flow routing. These were adjusted to match the shape and timing of the simulated hydrograph to the observed hydrograph, and to match the simulated peakflow to the observed peakflow. These adjustments included splitting many subareas into pervious and impervious components, with separate overland flow routing. This allowed better simulation of the rapid runoff from impervious surfaces located near stream channels.
The final stage in calibration was adjusting the storage-outflow relations for "reservoirs" in the model. These model reservoirs were needed to simulate the flood-water storage that occurs upstream from some of the culverts in the basin. There are also some extensive flat areas near the streams that are overflowed during storms which temporarily store water. Because the storage areas are not well defined, it was not possible to determine storage-outflow relations with any accuracy. The initial storage-outflow relations were adjusted to cause the simulated outflow to match the observed outflow.

The first stage of calibration was entirely independent of the other stages. The last three stages were conducted concurrently because all affected the timing, shape, and peakflow of the hydrograph.

The model was calibrated using rainfall and runoff data collected in the basin during four large storms (June 16-18, 1978; June 25, 26, 1978; June 30-July 2, 1978; and September 17-19, 1978) and five smaller storms (April 23-25, 1978; July 20-22, 1978; September 12-13, 1978; July 10-11, 1979; and August 5-6, 1979).

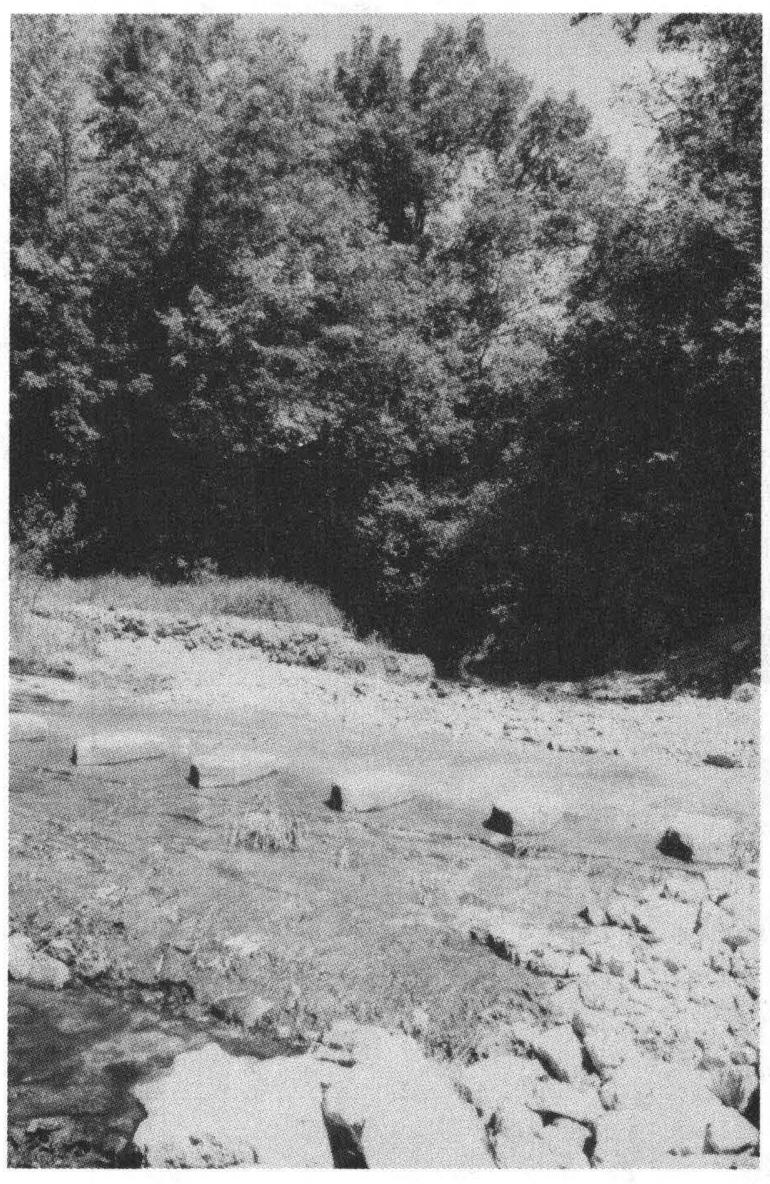

Figure 5. Upstream view of drop structure 4. 
The smaller storms were most useful in refining the model to simulate the effects of hydrologically active areas, especially impervious areas close to the channels. The larger storms were useful in refining the model to simulate the effects of the entire basin, especially the effects of the "reservoirs".

Sample hydrographs for two of the large storms used to calibrate the model are shown in figures 9-14. These figures show both observed and simulated runoff at three sites: The South Fork at U.S. Highway 14, the North Fork at Airport Road, and the main stem downstream from the confluence of the two forks at U.S. Highway 12. All of the figures are drawn to the same scale to facilitate comparisons.

These examples illustrate the fact that simulations of the main stem were often better than the simulations of the tributaries. This can be attributed to the limited rainfall information available. The few rain gages in the basin normally recorded rainfall amounts that were representative of the average rainfall over the whole basin, but were not always representative of the smaller subbasins. For example, during the storm of September 17,1978 , the recorded rainfall from the rain gages was fairly representative of the rainfall on the U.S. Highway 12 basin, but apparently was greater than the rainfall on the Airport Road basin, and less than the rainfall on the South Fork basin. During the storm of June 25, 1978, the rainfall from the rain gages was fairly representative for the Airport Road and U.S. Highway 12 basins, but apparently was greater than the rainfall on the South Fork basin.

Observation of rainfall on the basin confirmed the difficulty of obtaining representative samples of rainfall. The basin is elongated north to south, being about $7 \mathrm{mi}$ long and 2 to $4 \mathrm{mi}$ wide. Thunderstorms normally move in a general west to east direction. Individual storm cells would produce heavy rainfall along a narrow track across part of the basin. Usually a number of storm cells cross different parts of the basin over a period of several hours. Sometimes the total rainfall was fairly uniform

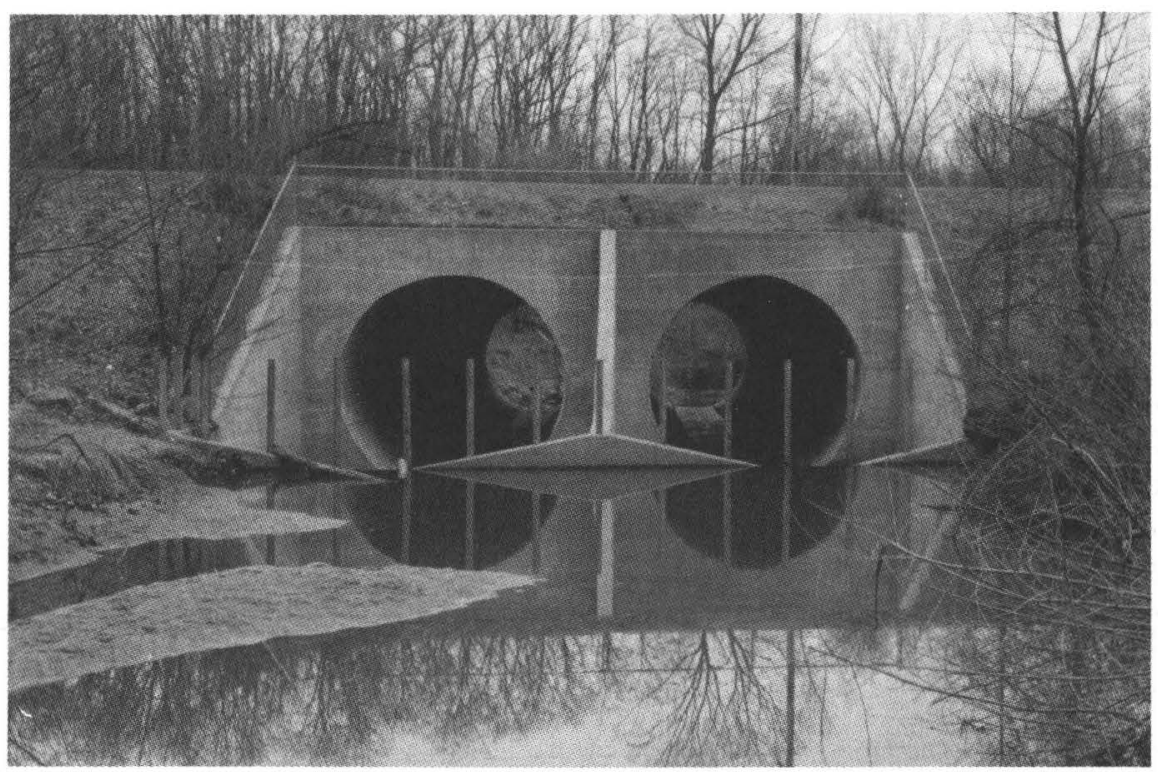

Figure 6. View downstream at Park Street erosion-control structure.

Table 4. Comparison of winter sediment loads between Pheasant Branch at Century Avenue and Pheasant Branch at mouth

\begin{tabular}{lccc}
\hline & & Sediment load, tons ${ }^{\mathbf{1}}$ \\
\cline { 2 - 4 } Period & Century Avenue & Mouth & Difference \\
\hline November-February, 1979 water year & 14 & 203 & 189 \\
November-February, 1980 water year & 28 & 326 & 298 \\
November-February, 1981 water year & 12 & 318 & 306 \\
\hline
\end{tabular}

${ }^{1}$ Suspended-sediment storm loads are not included. 
over the basin, but may have occurred at slightly different times. During other storms, the rainfall was not very uniform.

Despite the problems with nonuniform rainfall, the model produces usable results, especially at U.S. Highway 12. Figure 15 shows a comparison of observed and simulated flood peaks for the nine storms used in calibration. Over a wide range of discharges, the points are clustered about the line of equality. Use of this model with a long period of observed rainfall should give an annual series of simulated flood peaks that is very similar to the annual series of flood peaks which would be observed at the site over a like period if no changes were made in the basin.

\section{SIMULATIONS OF EFFECTS}

\section{Method}

The calibrated model was used to simulate storm runoff for all three sites for 68 years, for three separate conditions of the basin. The first simulation was for conditions prevailing at the time the rainfall and runoff data were collected and for which the model was calibrated. The second simulation was for partial urbanization of the basin, described by the land-use plans of the various units of local government involved in the basin. The third simulation was for complete urbanization of the basin, with all of the basin except designated flood plains included in the urban area. These simulations are explained in more detail in following sections.

The rainfall data used for all of the streamflow simulations were collected by the National Weather Service at Truax Field in Madison, Wis., about 10 mi east of the basin, over the period 1904-71. Rainfall at that site is expected to be representative of rainfall on the Pheasant Branch basin. For each year, one to five storms were selected to be sure that the storm producing the most runoff would be included. These storms were then used in the model to simulate runoff. The annual peak discharge simulated for each year was used to compute flood frequency at each site.

The same 68 years of rainfall data was used in all the simulations (current conditions, partial urbanization, and complete urbanization). As a result, the differences in simulated storm runoff were caused by changes in the model that were intended to simulate land-use changes in the basin.

The model was used only to analyze the changes in runoff attributable to changes in the infiltration capacity of the basin from increased urbanization. It was assumed that the channel system will not be changed substantially. It was also assumed that urban development will not change the drainage area by diverting storm-water runoff either into or out of the basin. There are extensive areas with no surface drainage within and adjacent to the basin. If development occurs in these areas and a storm-water drainage system is constructed to connect these areas with the Pheasant Branch basin, the increase in storm flow will be substantial. This was not considered in the model. The model was not used to simulate possible construction of detention basins with the urban development. Such basins would have the potential of reducing flood peaks.

\section{Current conditions}

The calibrated model, without modification, was used to simulate 68 years of peak storm runoff for selected rainfall events. This simulated runoff was used as a basis of comparison for the other simulations. Because the rainfall data were collected at some distance from the basin, the simulated runoff for any particular storm may be significantly different from the actual EXPLANATION
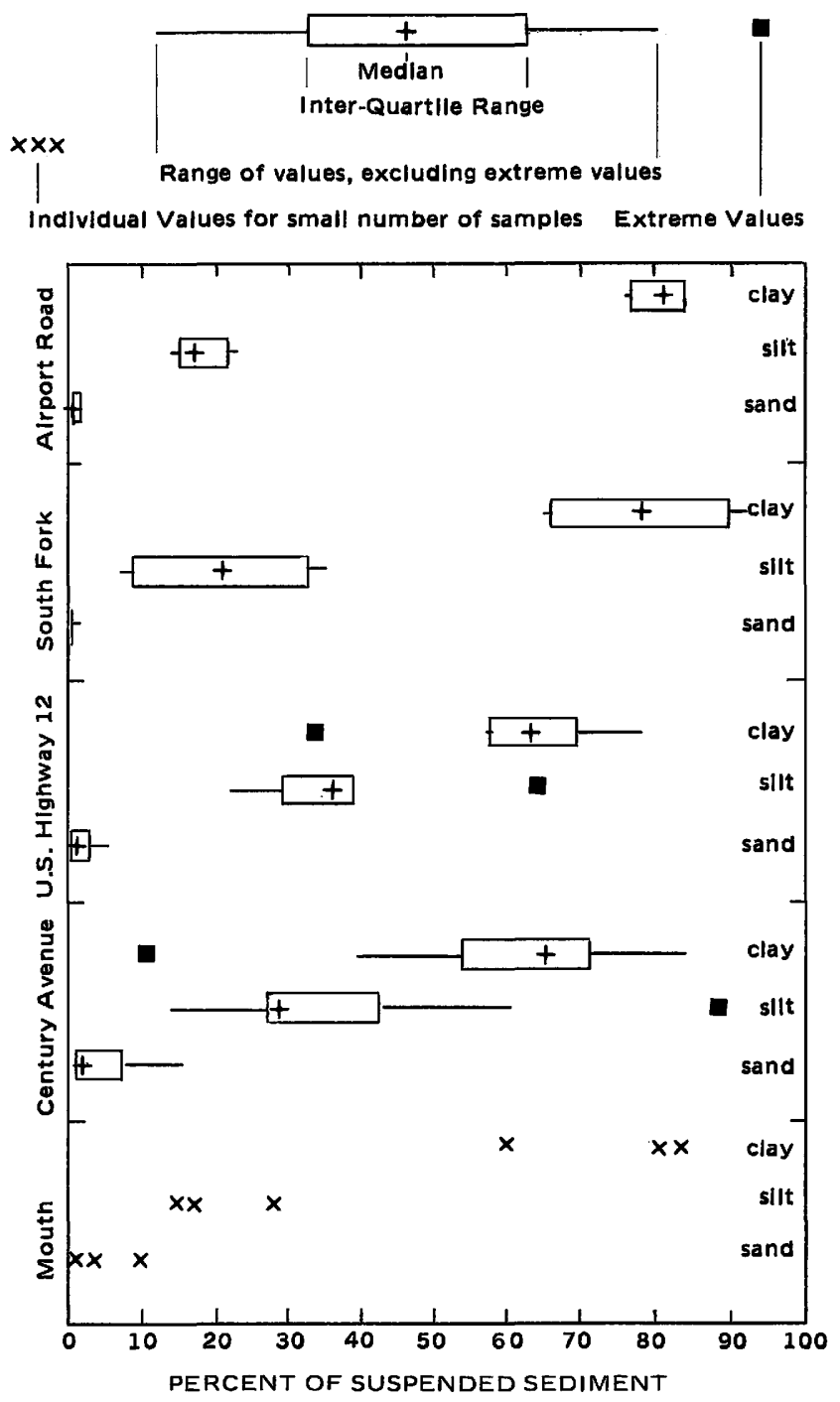

Figure 7. Box plots of percent of clay $(<0.004 \mathrm{~mm})$, silt $(0.004-0.0625 \mathrm{~mm})$, and sand $(0.0625-2.0 \mathrm{~mm})$ in sediment samples. 


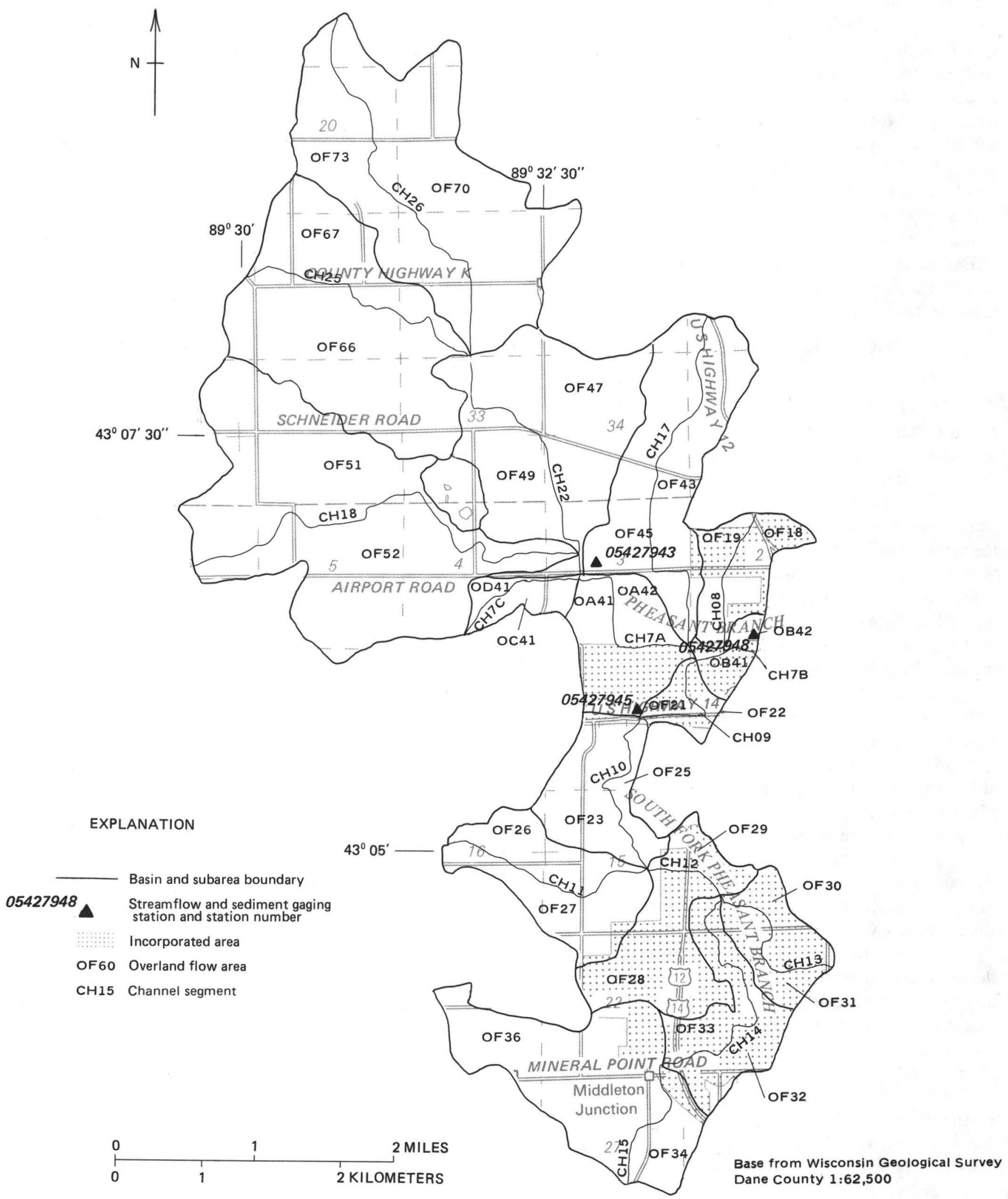

Figure 8. Basin and subareas used in the rainfall-runoff model. 
runoff on the same date. This is especially true for rainfall from thunderstorms, which can be very different over a distance of $10 \mathrm{mi}$. The differences between real and simulated runoff should be averaged out over a period of years so that the 68 simulated annual flood peaks are representative of the flood peaks that would actually occur if the basin remained unchanged for a long time.

\section{Partial urbanization}

The urban development expected to be completed in this basin according to current land-use projections will be referred to as partial urbanization. In order to make a reasonable simulation of runoff under partial urbanization conditions, estimates of the location and nature of future urbanization were required. The drainage basin of Pheasant Branch includes parts of the cities of Middleton and Madison and the unincorporated towns (mostly rural) of Springfield and Middleton. The cities have made projections and plans for future development in the Pheasant Branch area. The towns themselves do not have similar plans, but some planning functions are provided for them by the Dane County Regional Planning Commission.

Projections for future urbanization were obtained from the Master Plan for the city of Middleton (City of Middleton, 1982), for the areas within and adjacent to the city of Middleton. Maps included in this plan show various categories of land use including several densities of residential development, commercial and industrial development, as well as parks, conservancy areas and farmland.

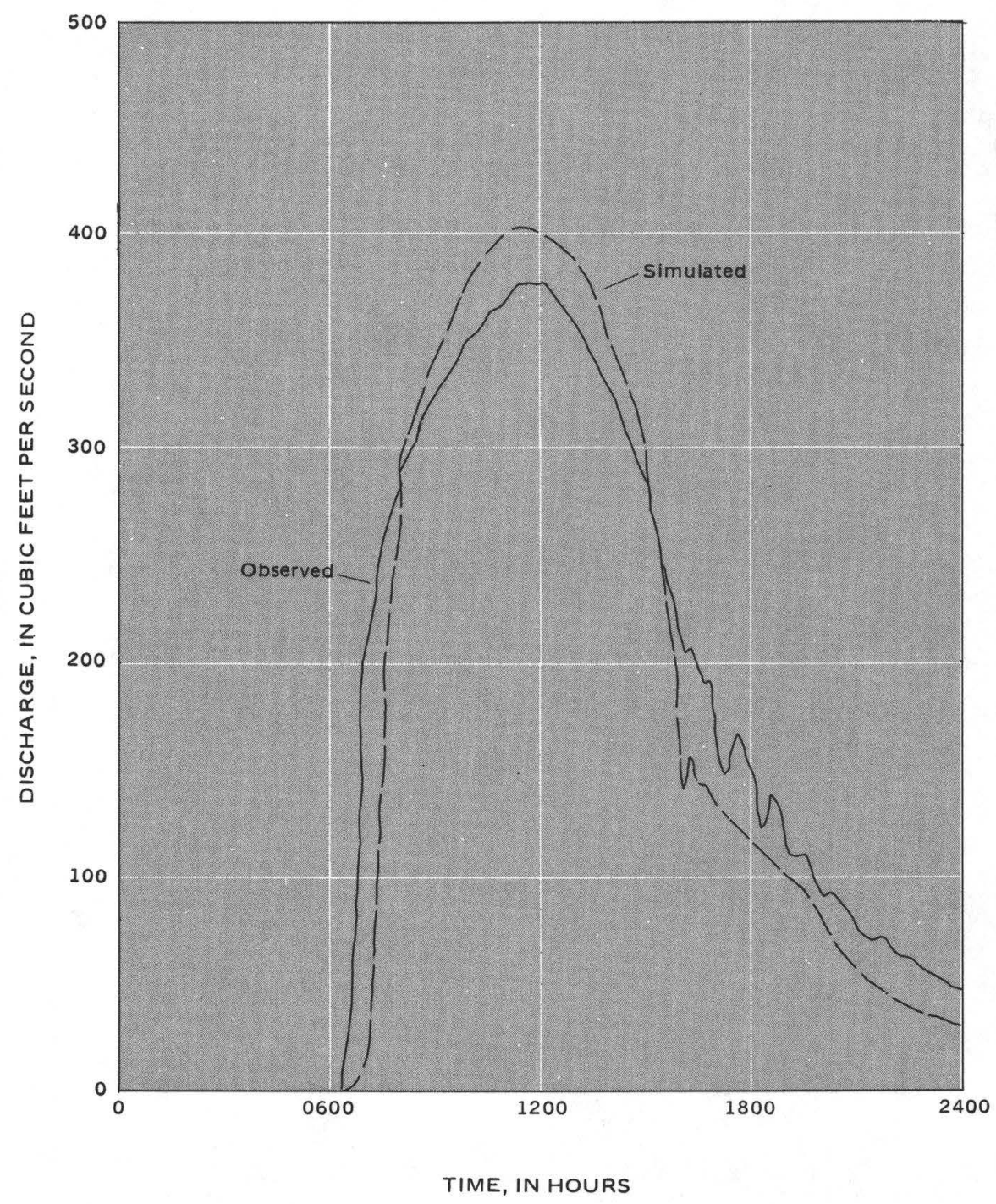

Figure 9. Observed and simulated hydrographs for storm of June 25, 1978, for Pheasant Branch at Middleton, Wis. (05427948). 


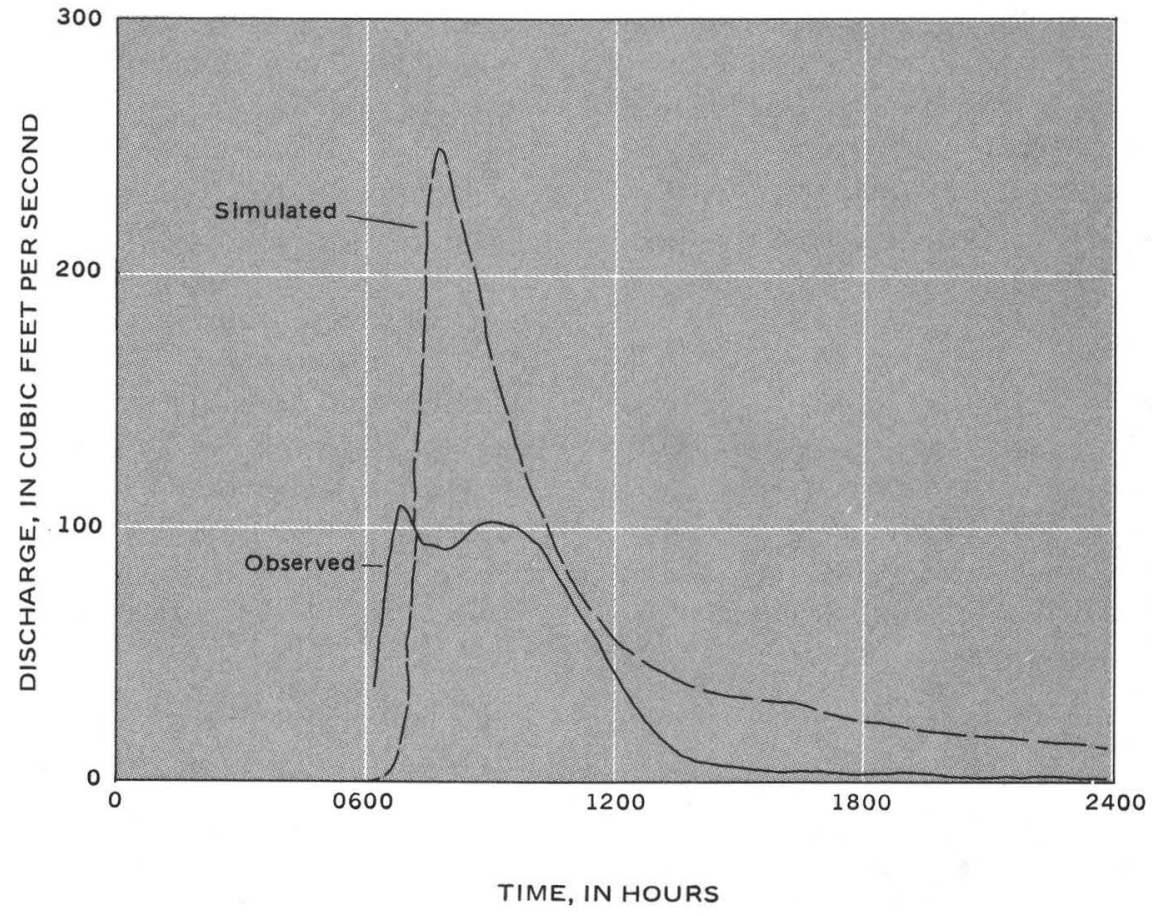

Figure 10. Observed and simulated hydrographs for storm of June 25, 1978, for South Fork Pheasant Branch at U.S. Highway 14 near Middleton, Wis. (05427945).

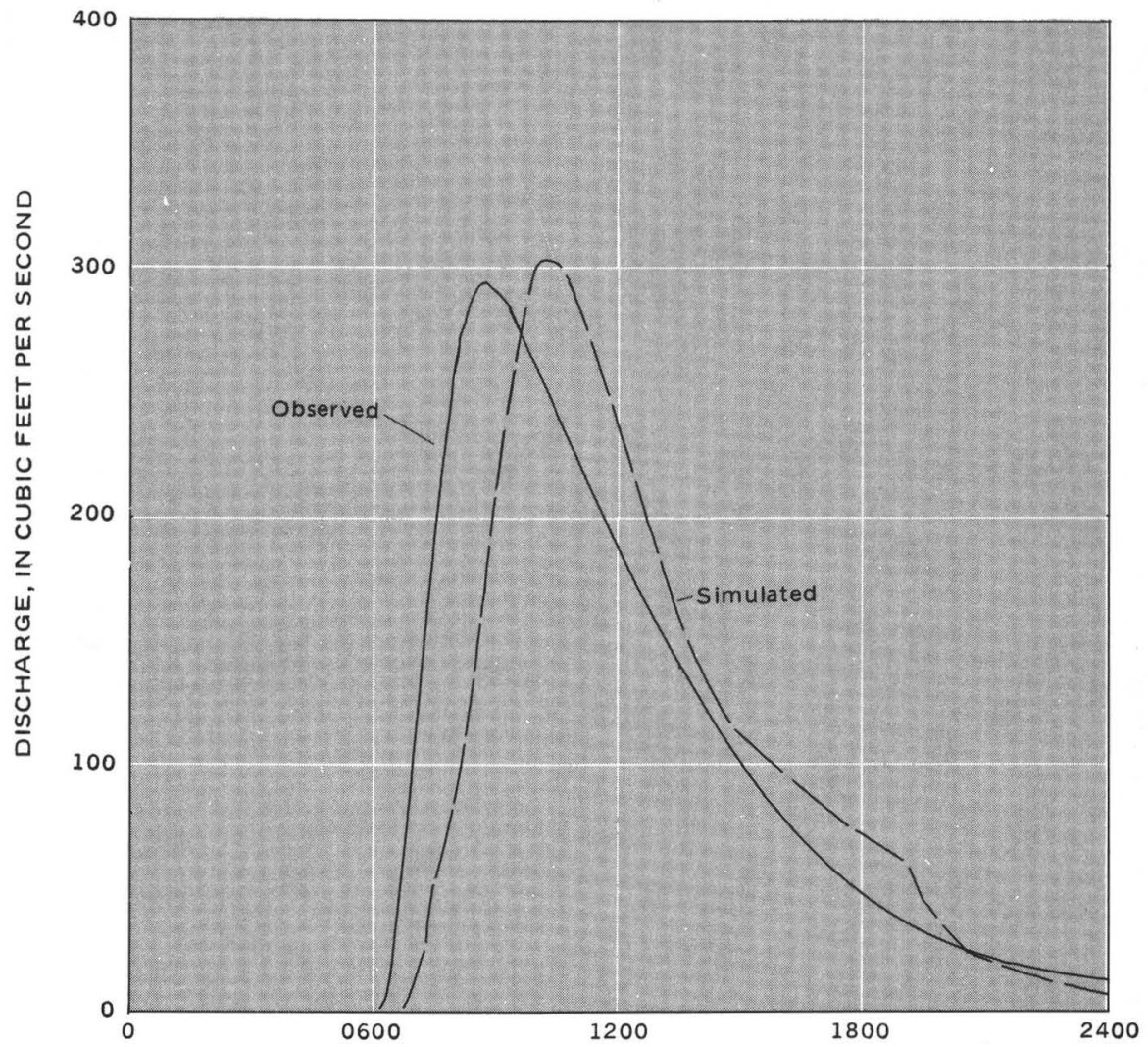

TIME, IN HOURS

Figure 11. Observed and simulated hydrographs for storm of June 25, 1978, for North Fork Pheasant Branch at Airport Road near Middleton, Wis. (05427943). 


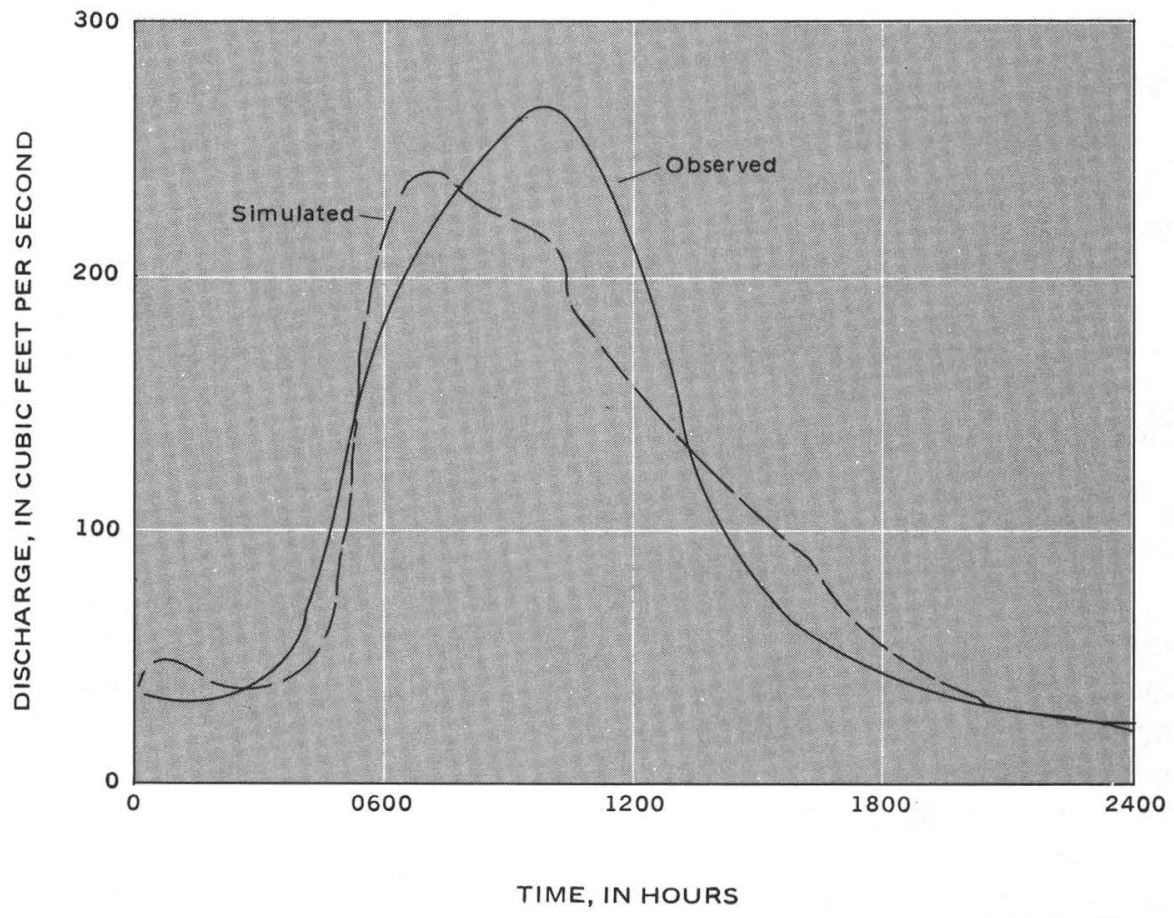

Figure 12. Observed and simulated hydrographs for storm of September 17, 1978, for Phea-

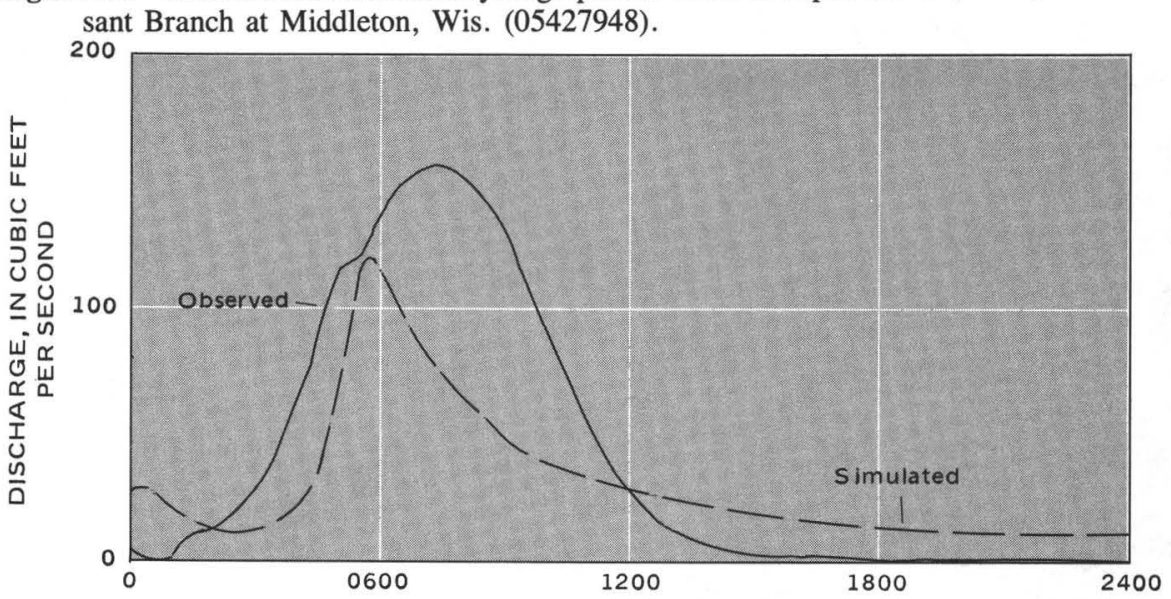

TIME, IN HOURS

Figure 13. Observed and simulated hydrographs for storm of September 17, 1978, for South Fork Pheasant Branch at U.S. Highway 14 near Middleton, Wis. (05427945).

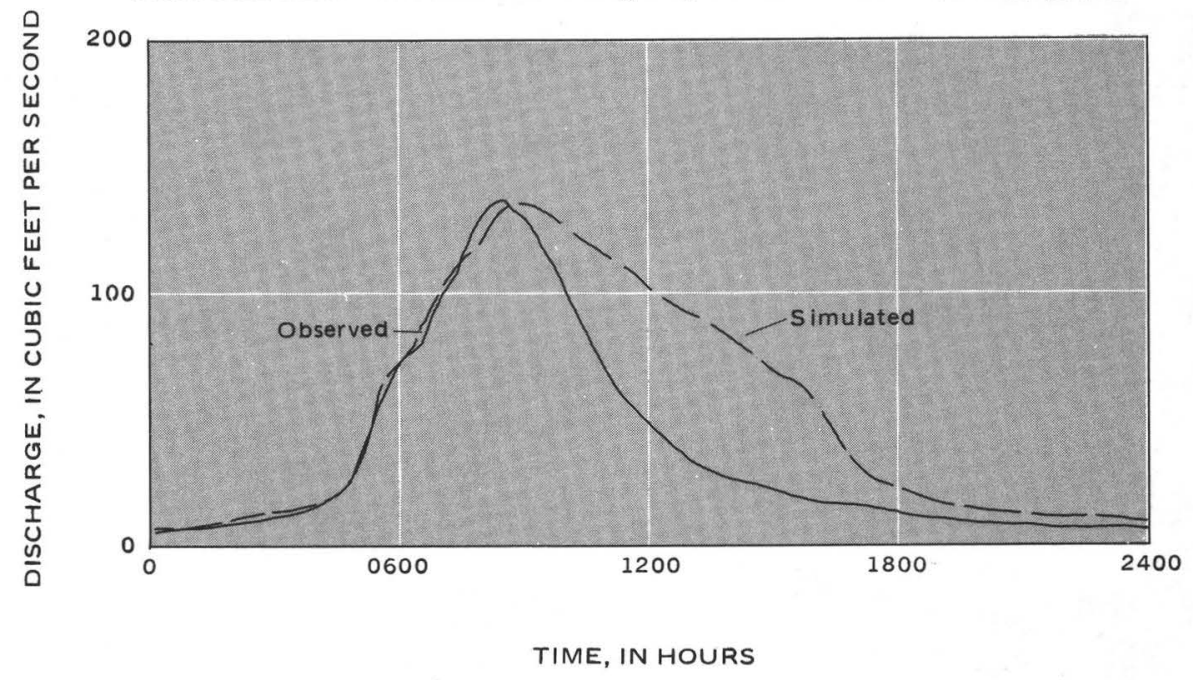

Figure 14. Observed and simulated hydrographs for storm of September 17, 1978, for North Fork Pheasant Branch at Airport Road near Middleton, Wis. (05427943). 
There are no published projections of urbanization in the Pheasant Branch basin for areas within the city of Madison. Work maps were obtained from the city engineer's office showing engineer's information similar to the Middleton Master Plan. Some of the categories used on this map are different than those of the Middleton map, especially in terms of density of residential areas.

There are also no urban-development plans or projections for areas outside the jurisdiction of the cities. However, there is a Farmland Preservation Plan Dane County, Wis. (Dane County Regional Planning Commission, 1981), which was adopted as a part of the master plan for Dane County. Although this plan focuses on the preservation of farmlands, the maps show the areas in which urban development (both sewered and unsewered) is expected to occur.

The maps from three sources are not identical in the areas where they overlap. This is caused by slight differences in policy among the agencies involved and by the different purposes for which the plans were prepared. In reconciling these differences for the purpose of simulation, the choice was generally made to use the category of land use having greater runoff potential.

The projections for future urbanization do not specify any particular year in the future when the development is likely to be completed. The only suggestion of a date is in the Middleton Master Plan which states (p. 9, 10) that the residential densities included in the plan imply a population that exceeds the population projections for the year 2000 . This projection is

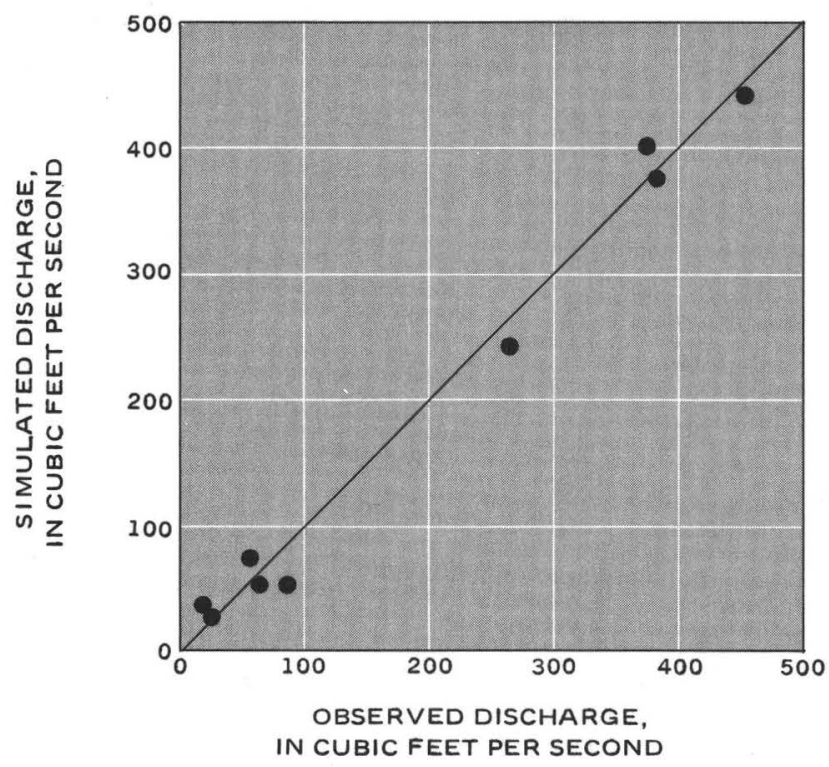

Figure 15. Observed and simulated peak discharges for Pheasant Branch at Middleton, Wis. (05427948) for nine storms used to calibrate the model. vague and subject to revision, but suggests that the projected urbanization is unlikely to be completed for at least 20 years.

The model was adjusted to simulate partial urbanization by increasing the impervious areas of each subarea where development was projected. The maps of projected urbanization were combined with maps of the basin subdivisions. For each subarea, the percentage of the area was determined for each of six land-use categories:

Agricultural (which includes conservancy and parks)

Low-density residential ( 3 to 5 units per acre)

Medium-density residential (5 to 8 units per acre)

High-density residential ( 8 to 14 units per acre)

Commercial

Industrial

Each of these categories was assumed to have a proportion of impervious area that contributes directly to runoff (often called effective impervious areas or directly connected impervious areas). The proportions were determined from average values measured on nearby areas that are already developed. The impervious percentages used are summarized in the following table:

Percent

Effective

Land-Use Category Impervious Area

Agricultural

Low-density residential 2

Medium-density residential 18

High-density residential 22

Commercial 25

35

Industrial

40

The percentage of each land-use category in the major subdivisions of the basin are summarized below:

\begin{tabular}{lcc} 
Land-Use Category & $\begin{array}{c}\text { North Fork } \\
\text { basin }\end{array}$ & $\begin{array}{c}\text { South Fork } \\
\text { basin }\end{array}$ \\
\cline { 2 - 3 } Agricultural & 91 & 39 \\
Low-density residential & 9 & 27 \\
Medium-density residential & 0 & 0 \\
High-density residential & 0 & 17 \\
Commercial & 0 & 5 \\
Industrial & 0 & 3 \\
& Intervening & Entire \\
Land-Use Category & area & basin \\
\cline { 2 - 3 } Agricultural & 67 & 73 \\
Low-density residential & 10 & 14 \\
Medium-density residential & 4 & 3 \\
High-density residential & 0 & 5 \\
Commercial & 6 & 2 \\
Industrial & 13 & 3
\end{tabular}


For each subarea that had more than one land-use category, the weighted average percentage of impervious area was determined based on area.

The adjustment of the model to simulate projected urbanization was limited to increasing the impervious area. The channel network simulated by the model was not changed. The land-use plans indicate that most of the stream channels are to be in conservancy or park areas. This usually means little structural change in the channels.

The model, with simulated impervious area increased to simulate the projected urbanization, was run using the same 68 years of rainfall data that were used to simulate current conditions.

\section{Complete urbanization}

The Pheasant Branch basin is adjacent to a growing urban area. It is probable that at some time in the future the entire basin will be included in urban development. Such extensive development is not included in the plans of any of the local agencies, so no year can be associated with such development.

It was not reasonable to prepare maps showing different categories of land use in different areas because no agency is planning for total development. Instead, rough estimates were made of the percentages of each subarea which would be developed for each of the categories of land use.

Some assumptions were necessary in estimating the land use. One assumption was that most development would be predominantly low density residential because this basin would be an outlying area of an urban center. An allowance of 5 to 10 percent commercial development was assumed for subareas along principal roadways. A similar allowance was assumed for industrial development adjacent to existing industrial areas. It was assumed that designated flood plains would remain in open space use. In addition, each subarea was assumed to contain 15 percent park lands, greenways, or other open space. In all cases, development of a subarea was assumed to be similar to any adjacent areas where development already exists or is planned. The percentages of each land-use category in the major subdivisions of the basin are summarized below.

\begin{tabular}{lcc} 
Land-Use Category & $\begin{array}{c}\text { North Fork } \\
\text { basin }\end{array}$ & $\begin{array}{c}\text { South Fork } \\
\text { basin }\end{array}$ \\
\cline { 2 - 3 } Agricultural & 16 & 14 \\
Low-density residential & 76 & 50 \\
Medium-density residential & 4 & 10 \\
High-density residential & 2 & 17 \\
Commercial & 2 & 6 \\
Industrial & 0 & 3
\end{tabular}

\begin{tabular}{lcc} 
Land-Use Category & $\begin{array}{c}\text { Intervening } \\
\text { area }\end{array}$ & $\begin{array}{c}\text { Entire } \\
\text { basin }\end{array}$ \\
\hline Agricultural & 67 & 18 \\
Low-density residential & 10 & 61 \\
Medium-density residential & 4 & 6 \\
High-density residential & 0 & 7 \\
Commercial & 6 & 4 \\
Industrial & 13 & 4
\end{tabular}

The intervening area has a high percentage of "agricultural" land use, even in this fully developed basin simulation, because a large part of this area is in a designated flood plain. It was assumed that if true agricultural use stops in this area, the new uses will be for parkland, conservancy, or other open space use (and will not include paving any significant parts of this area).

The model was changed to simulate the increased impervious area. The same 68 years of rainfall data were used to simulate storm runoff from the fully urbanized basin.

\section{Results}

Flood frequency was computed for each of the three simulated conditions at each of the three sites. The peak simulated discharge for each of the 68 years was selected. From each set of conditions the flood frequencies were determined as summarized in table 5 . It can be seen from these data that floods of all magnitudes are increased by urbanization and that smaller, more frequent floods are increased more than the larger, infrequent floods.

Partial urbanization increased the simulated 2-year floods by 320 percent on the South Fork and 32 percent on the North Fork. The South Fork had a much greater increase because most of the urbanization is concentrated in that basin. Complete urbanization increased the simulated 2-year flood by 360 percent on the South Fork and 220 percent on the North Fork, compared to current conditions.

From table 5, it is apparent that the largermagnitude flood peaks at U.S. Highway 12 are smaller than those at either of the tributaries. This is caused by a large amount of "reservoir" storage in the model between the two tributary sites and U.S. Highway 12 . This model "reservoir" simulates the natural flood-plain storage of the large area of the flat land adjacent to the stream in this reach.

\section{EFFECTS OF URBANIZATION ON SEDIMENT LOADS}

It is very difficult to predict the change in sediment loads between the current land-use conditions and a partial to fully urbanized condition. The effects of urbanization on sediment loads depends on the type of ur- 
ban development and the way in which it occurs. Construction activities can loosen soil and expose it to erosion. Unless special precautions are taken, this can increase sediment loads significantly. After construction is completed, and cultivated fields are replaced by buildings, pavement, and grass, the sediment loads originating from these areas are reduced considerably. However, sediment loads in the streams may not decrease if peak discharges increase as simulated by the rainfall-runoff model. Streambank erosion could become a source of sediment if peak discharges increase and the streambanks are not protected.

In the headwaters area of the South Fork basin, for example, the construction of homes, apartments, and businesses is rapidly increasing. The increased runoff from this newly created urban area must flow through the unprotected natural channel downstream and will probably cause increased channel and streambank erosion resulting in higher sediment loads. The sediment loads would be expected to increase until the basin is fully urbanized and the channel is completely protected. This same situation would probably occur in the other parts of the basin as they become developed.

Between U.S. Highway 12 and Century Avenue there was a slight decrease in sediment loads. Some of the sediment was trapped behind the Park Street erosioncontrol structure but little additional sediment was contributed from this urbanized area. This again indicates that sediment loads may decrease as the basin nears full development.

As peak discharges and runoff increase, channel and streambank erosion can be expected to continue downstream from Century Avenue. This eroded material plus sediment carried from upstream areas of the basin will continue to be deposited in the Pheasant Branch marsh. Serious damage to this marsh could result with the marsh evenutally losing its effectiveness as a sediment trap.

\section{EFFECTS OF URBANIZATION ON CHANNEL MORPHOLOGY}

Periodic channel surveys were made of 56 cross sections along about $5.6 \mathrm{mi}$ of the main channel of Pheasant Branch from County Highway $M$ and $Q$ at the mouth in Middleton to County Highway K near Ashton (fig. 1). The first survey was made in 1971 by the U.S. Geological Survey as part of a flood investigation (Lawrence and Holmstrom, 1972). In 1977, the same cross sections were relocated as closely as possible, monumented to aid future relocation, and resurveyed.

Table 5. Magnitude of flood peaks at selected recurrence intervals for three simulated conditions at three sites

\begin{tabular}{|c|c|c|c|}
\hline \multirow{2}{*}{$\begin{array}{c}\text { Recurrence interval } \\
\text { (years) }\end{array}$} & \multicolumn{3}{|c|}{ Simulated annual maximum discharge $\left(\mathrm{ft}^{3} / \mathrm{s}\right)$} \\
\hline & Present conditions & Projected urbanization & Complete urbanization \\
\hline \multicolumn{4}{|c|}{ Pheasant Branch at U. S. Highway 12 (05427948) } \\
\hline 2 & 176 & 350 & 426 \\
\hline 5 & 420 & 483 & 572 \\
\hline 10 & 531 & 567 & 666 \\
\hline 25 & 642 & 670 & 785 \\
\hline 50 & 713 & 744 & 872 \\
\hline 100 & 782 & 816 & 958 \\
\hline \multicolumn{4}{|c|}{ South Fork Pheasant Branch at U. S. Highway 14 (05427945) } \\
\hline 2 & 79.8 & 338 & 368 \\
\hline 5 & 233 & 583 & 633 \\
\hline 10 & 414 & 778 & 842 \\
\hline 25 & 692 & 1,060 & 1,140 \\
\hline 50 & 912 & 1,290 & 1,390 \\
\hline 100 & 1,140 & 1,550 & 1,670 \\
\hline \multicolumn{4}{|c|}{ North Fork Pheasant Branch at Airport Road (05427943) } \\
\hline 2 & 87.0 & 115 & 282 \\
\hline 5 & 264 & 303 & 549 \\
\hline 10 & 470 & 517 & 819 \\
\hline 25 & 872 & 929 & 1,300 \\
\hline 50 & 1,300 & 1,360 & 1,790 \\
\hline 100 & 1,860 & 1,930 & 2,420 \\
\hline
\end{tabular}


The third survey was made in 1979 , and the final survey was begun in late summer 1980 and was completed in the early summer of 1981 . Observed changes in the channel from 1971 to 1977 were documented in a preliminary report (Grant and Goddard, 1980).

\section{METHODS}

To evaluate changes in channel size between surveys, cross-section properties were computed at each survey site using a common water-surface elevation. The common water-surface elevation was chosen as the elevation caused by the mean annual flood (occurs on the average of once in every 2.33 years). This flood was assumed to represent the channel-forming discharge.

The elevation of the mean annual flood at each cross section surveyed in 1971 was determined by the step-backwater method. The channel width, crosssection area, and mean depth were computed for the same elevations for each of the four surveys. Changes in these properties between the surveys showed the degree of changes in the channel at each cross section.

\section{CHANNEL SURVEY}

The surveys of 1971 and 1977 showed substantial channel degradation and enlargement. The subsequent surveys revealed less significant changes in the channel. The large channel changes observed between the 1971 and 1977 surveys may have resulted partly from the inability to accurately relocate the cross sections in 1977. However, the general overall trend was channel degradation through the individual reaches. Figure 16 illustrates the changes in streambed elevation for the various surveys. In 1980, the streambed elevation ranged from $3 \mathrm{ft}$ higher at some locations to almost $4 \mathrm{ft}$ lower than in 1971. Two areas of significant degradation were downstream from Century Avenue (fig. 17) and downstream from Airport Road (fig. 18).

The large positive change in the thalweg elevation just upstream from Park Street is the filling of the channel upstream from the erosion-control structure at this site. The large negative changes in thalweg elevation upstream from Airport Road were the result of channel dredging in October 1978. The channel refilled about $2 \mathrm{ft}$ by 1980 .

Changes in mean channel cross-section area, width, and depth and changes in streambed elevation from 1971 to 1981 are shown in table 6. The crosssection area is a good summary of the channel size. For the entire section upstream from the marsh, the crosssection area increased 22 percent between 1971 and 1977. The greatest increase was in reach 1 , from the marsh to Century Avenue, where the cross-section area increased 85.7 percent in 6 years. There was a 2.6 percent increase in the overall cross-section area between 1977 and 1979. The greatest increase (28.1 percent) in reach 6, from Airport Road to Schneider Road, was caused by dredging of this reach in 1978 . There was a 2.1 percent decrease in the overall cross-section area between 1979 and 1980-81. The greatest decrease (14.4 percent) was in reach 7, from Schneider Road to County Trunk Highway $\mathrm{K}$.

Total channel volume of Pheasant Branch from the upstream end of the marsh to County Trunk Highway $\mathrm{K}$ increased 22.1 percent from $2,829,000 \mathrm{ft}^{3}$ in 1971 to $3,455,000 \mathrm{ft}^{3}$ in 1977 and increased by 2.58 percent to $3,544,000 \mathrm{ft}^{3}$ in 1979. However, between 1979 and 1980 a 2.12 percent reduction to $3,469,000 \mathrm{ft}^{3}$ occurred.

\section{RELATIONSHIP OF CHANNEL MORPHOLOGY AND SUSPENDED-SEDIMENT LOADS}

The surveyed cross sections between U.S. Highway 12 and Century Avenue provide a measure of the total erosion or sediment deposition in the channel. The gages at each end of the reach provide measures of the sediment moving into or out of the reach. Comparison of these data provides some insight into the relationship between channel morphology and suspendedsediment loads.

It may be seen from table 6 that there was only a very slight change in the average area of the cross sections over the period 1977-1980 and 1981. Multiplying the change in area ( 0 between Century Avenue and Park Street, $-3 \mathrm{ft}^{2}$ between Park Street and U.S. Highway 12) by the respective length of the reaches shows that about $500 \mathrm{yd}^{3}$ of material accumulated within the reach. This represents about 400-500 tons of sediment accumulation within the channel, depending on the density of the sediments.

During water years $1978-80,8,124$ tons of sediment passed U.S. Highway 12, and 7,962 tons passed Century Avenue. This indicates that about 160 tons accumulated within this reach. The storm sewers and surface runoff along this reach certainly contributed some additional sediment. Thus, both the channel surveys and sediment station data indicate that relatively little sediment accumulated in the reach.

There is evidence that the Park Street erosioncontrol structure traps sediment. The short reach upstream from this structure can account for the reduction in sediment loads between U.S. Highway 12 and Century Avenue. Figure 19 is a plot of a cross section $40 \mathrm{ft}$ upstream from Park Street. In January 1979 about $375 \mathrm{yd}^{3}$ of material (possibly $300-400$ tons of dry sediment) was dredged from the channel. The channel was also dredged in 1974 or 1975 (City of Middleton, oral commun., 1979). Figure 19 shows the sediment deposition at the cross section from 1979 to 1981 . Within 2 $1 / 2$ years, the channel had refilled with sediment. After the channel upstream from the Park Street structure fills 
Table 6. Change in mean stream-channel properties between 1971 and $1981^{1}$

\begin{tabular}{|c|c|c|c|c|c|c|c|c|c|c|c|c|c|c|c|c|c|c|}
\hline \multirow{2}{*}{$\begin{array}{l}\text { Reach } \\
\text { number }\end{array}$} & \multirow{2}{*}{ Length } & \multirow{2}{*}{ Description } & \multicolumn{4}{|c|}{ Cross-section area $\left(\mathrm{ft}^{2}\right)$} & \multicolumn{4}{|c|}{ Cross-section width $(f t)$} & \multicolumn{4}{|c|}{ Cross-section depth ( $f t)$} & \multicolumn{4}{|c|}{$\begin{array}{c}\text { Average change in streambed } \\
\text { elevation }(f t)\end{array}$} \\
\hline & & & 1971 & 1977 & 1979 & $1980 / 81$ & 1971 & 1977 & 1979 & $1980 / 81$ & 1971 & 1977 & 1979 & $1980 / 81$ & $\begin{array}{l}1971- \\
1977\end{array}$ & $\begin{array}{l}1977- \\
1979\end{array}$ & $\begin{array}{c}1979- \\
1980 / 81\end{array}$ & $\begin{array}{l}1971- \\
1980 / 81\end{array}$ \\
\hline $1 \mathrm{~A}$ & 1,130 & $\begin{array}{l}\text { Mouth to upstream } \\
\text { end of marsh }\end{array}$ & 58.9 & 69.2 & 79.1 & 81.0 & 26.5 & 40.0 & 38.7 & 40.1 & 2.22 & 1.73 & 2.04 & 2.02 & -0.86 & -0.57 & +0.07 & -1.37 \\
\hline 1 & 3,150 & $\begin{array}{l}\text { Upstream end of marsh } \\
\text { to Century Avenue }\end{array}$ & 79.7 & 148 & 141 & 128 & 35.3 & 47.8 & 44.7 & 43.2 & 2.26 & 3.10 & 3.15 & 2.96 & -2.07 & -0.15 & +0.48 & -1.92 \\
\hline 2 & 3,600 & $\begin{array}{l}\text { Century Avenue to } \\
\text { Park Street }\end{array}$ & 93.5 & 112 & 112 & 112 & 28.1 & 28.9 & 28.7 & 29.1 & 3.33 & 3.88 & 3.90 & 3.85 & -1.30 & +0.13 & +0.07 & -1.10 \\
\hline 3 & 4,450 & $\begin{array}{l}\text { Park Street to U.S. } \\
\text { H1ghway } 12\end{array}$ & 110 & 121 & 123 & 118 & 30.7 & 30.1 & 29.7 & 29.9 & 3.58 & 4.02 & 4.14 & 3.95 & -0.10 & +0.14 & -0.06 & +0.66 \\
\hline 4 & 2,400 & $\begin{array}{l}\text { U.S. H1ghway } 12 \text { to } \\
\text { South Pork }\end{array}$ & 124 & 155 & 119 & 145 & 31.6 & 35.8 & 35.6 & 36.1 & 3.92 & 4.33 & 3.34 & 4.02 & -0.28 & +0.55 & +0.40 & +0.68 \\
\hline 5 & 7,550 & $\begin{array}{l}\text { South Fork to } \\
\text { Alrport Road }\end{array}$ & 79.0 & 106 & 110 & 117 & 29.6 & 32.2 & 31.8 & 32.4 & 2.67 & 3.29 & 3.46 & 3.61 & -0.86 & -0.51 & -0.03 & -1.46 \\
\hline 6 & 6,020 & $\begin{array}{l}\text { Airport Road to } \\
\text { Schneider Road }\end{array}$ & 79.8 & 91.3 & 117 & 105 & 34.3 & 30.8 & 31.8 & 30.4 & 2.33 & 2.96 & 3.68 & 3.45 & -1.36 & -1.10 & +0.92 & -1.64 \\
\hline 7 & 7,600 & $\begin{array}{l}\text { Schnelder Road to } \\
\text { County Trunk } \\
\text { Highway } \mathrm{K}\end{array}$ & 49.7 & 43.1 & 43.1 & 36.9 & 22.6 & 18.9 & 18.1 & 17.8 & 2.20 & 2.28 & 2.38 & 2.07 & -0.05 & +0.08 & +0.12 & +0.30 \\
\hline Total & 34,770 & $\begin{array}{l}\text { Upstream end of } \\
\text { marsh to county } \\
\text { Trunk Highway } K \\
\text { (Reaches } 1 \text { to } 7 \text { ) }\end{array}$ & 81.4 & 99.4 & 102 & 99.8 & 29.5 & 30.1 & 29.7 & 29.4 & 2.76 & 3.30 & 3.43 & 3.39 & -0.81 & -0.20 & +0.25 & -0.64 \\
\hline
\end{tabular}

${ }^{1}$ All cross-section properties are referenced to the mean annual flood elevation computed using the 1971 cross-section survey. 
with sediment, the structure loses its effectiveness in trapping sediment.

The average channel size between Century Avenue and Park Street remained relatively constant from 1977 o 1981 (table 6), although there are isolated exceptions. The channel bottom throughout this reach is composed mainly of gravel and cobbles and may be somewhat resistant to erosion. Considerable scouring of the channel bed has occurred downstream from the drop stucture along with an increase in cross-sectional area.

Major changes have occurred in the channel downstream for me rbanized subbasin ending at Cen$8,000 \mathrm{yd}^{3}$ between 1971 and 1977, which indices the bout 7,000 to 8,000 ton of moterial wey ered fom his reach. This chent in part from the rerouting of the stream through the marsh in 1971. From 1977 to 1981, the channel volume of the reach between the marsh and Century Avenue
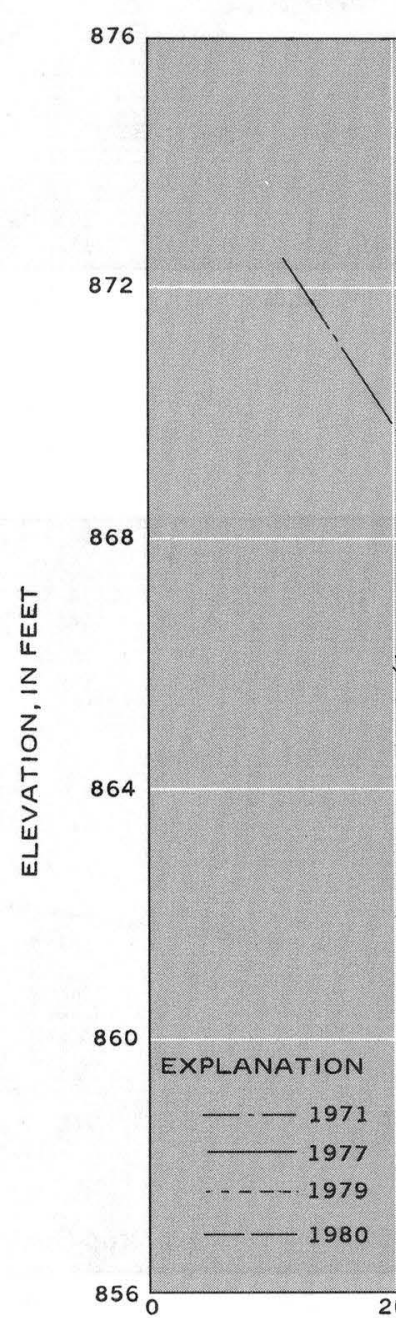

decreased by 13 percent, indicating that some sediment deposition is now occurring upstream from the marsh. Most of the deposition is occurring near the marsh as shown by the cross-section plot in figure 20 . This cros section is at the upstream end of the marsh about 3,200 $\mathrm{ft}$ downstream from Century Avenue. The streambed rose $2.6 \mathrm{ft}$ between 1977 and 198

\section{RESULTS}

It is impossible to say exactly what effect the predicted changes in streamflow will have on the stream channel at any particular localon. Hover, studies Leopold, Wolman (Lepoliler, 1964; Dunne Leopold, 1978) have suggested some general relani ships between flood discharges and chent ize the give some indication of the changes to be expected. It has been shown that in stream channels which are free to adjust their shape to the prevailing discharge, fo

DISTANCE, IN FEE

Figure 17. Cross-section plot of Pheasant Branch showing erosion downstream from Century Avenue. 
discharge at a constant frequency, the width varies as the 0.5 power of discharge and the depth varies as the 0.4 power of discharge (Dunne and Leopold, 1978, p. 639).

Stream channels are normally of such a size to carry the mean annual flood within their banks. If the mean annual flood (that is, the 2-year flood) increases, it is reasonable to expect the channels to erode until they are again large enough to accommodate the larger discharge. Table 7 summarizes the increases in width and depth resulting from the model-simulated increase in the 2-year flood peak using the power relationships cited above.

The predicted increases in width and depth would take place gradually over a period of years as the pattern of erosion and deposition of sediments adjusts the size of the channel to match the new pattern of flow. The details of how these increases are accomplished are not predictable in general. Depth of bankfull flow can be increased by deposition raising the banks, or by erosion lowering the streambed, or by a combination of both. Width can be increased by erosion of one or both; banks or by erosion of one bank exceeding the deposition on the other.

\section{APPLICATION OF MODEL FOR EVALUATION OF DEVELOPMENT ALTERNATIVES}

A municipality seeking to guide development to reduce the adverse impacts of urbanization on streamflow needs more detailed information than the total change in flood peaks at the outlet of the basin. In order to make decisions on proposed developments in certain areas they require some means of estimating how development in certain areas will affect runoff. A larger city with a staff of engineers might be able to utilize a rainfall-runoff model such as DR3M and use it to analyze the effects of individual developments, but most smaller cities and towns do not have the staff to undertake such an effort.

To meet the need for more detailed runoff data at various locations in the basin in an economical fashion, the DR3M model was used to determine the increase in storm runoff due to urbanization in each of the 18 subareas (fig. 8) in the model. The subareas were modeled in pairs with two subareas and the channel between them treated as one subbasin. The runoff from this subbasin was then simulated for both current and

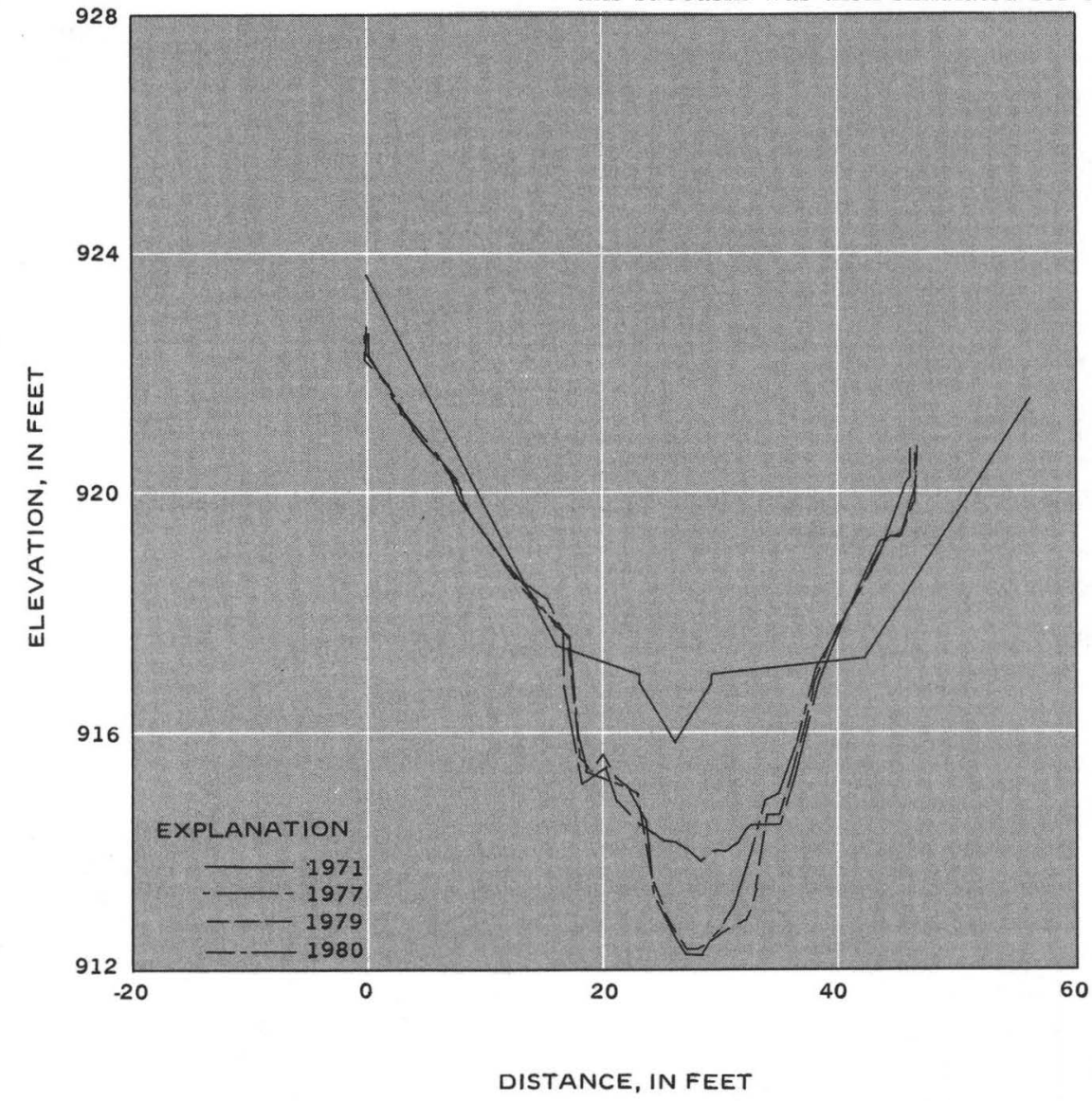

Figure 18. Cross-section plot of Pheasant Branch showing channel degradation downstream from Airport Road from 1971 to 1980. 
fully developed conditions. The staff of the city can use the hydrogaphs for current and fully developed conditions to evaluate the effects of development in smaller areas. For example, by comparing the hydrographs they can determine the size of detention basins needed to prevent an increase in runoff or they can determine the size of channel structures needed to convey the additional runoff, depending on their goals and policies.
Four storms were selected for simulation on each subbasin to approximate the 2-, 5-, 10-, and 25-year floods. The four flood magnitudes were determined by flood-frequency analysis of the 68 years of simulated flood peaks for the subbasin for current conditions. Because individual subbasins have different runoff characteristics, different storms best approximate the four flood magnitudes in different subbasins.

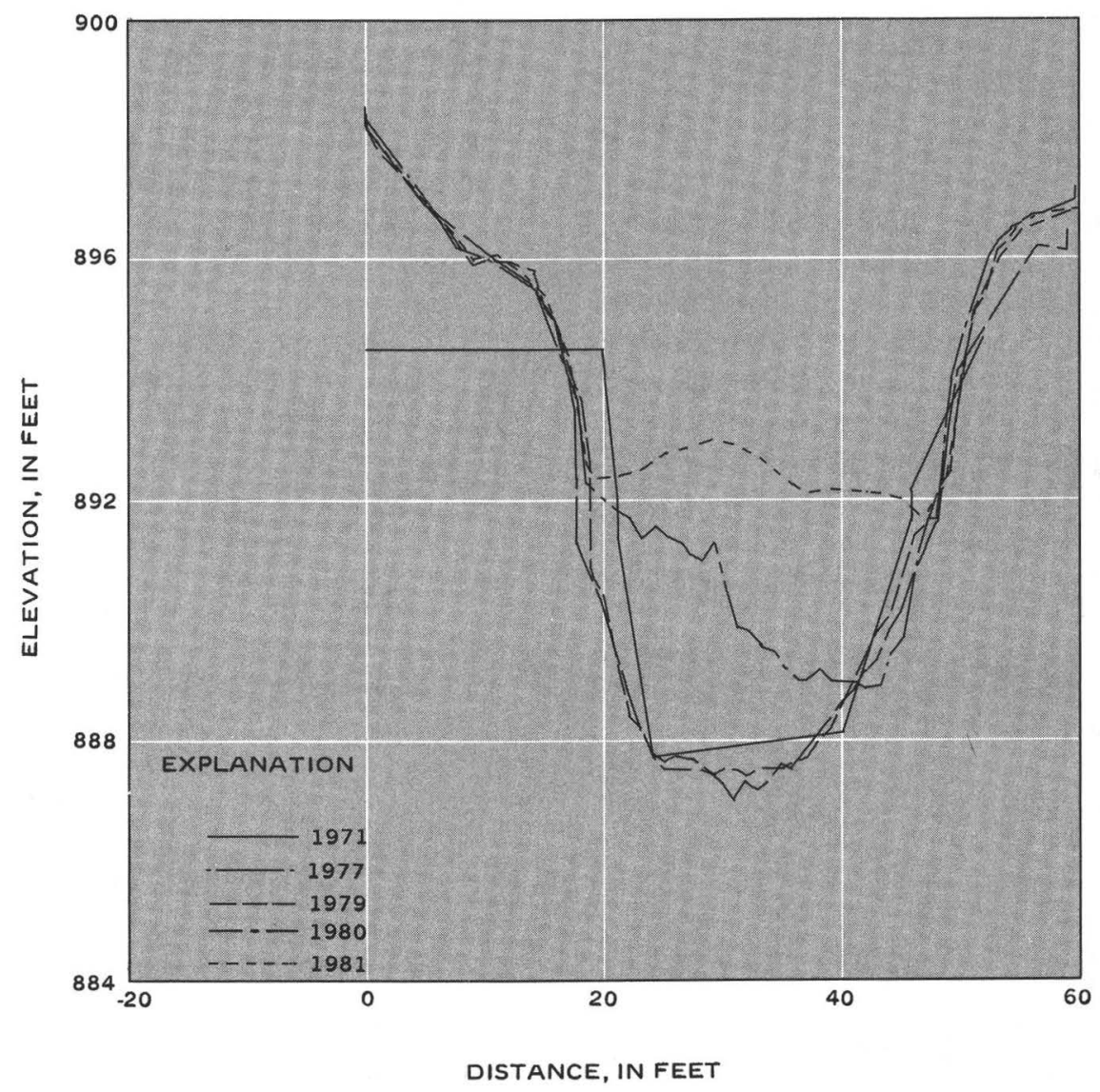

Figure 19. Cross-section plot of Pheasant Branch showing sediment deposition upstream from Park Street.

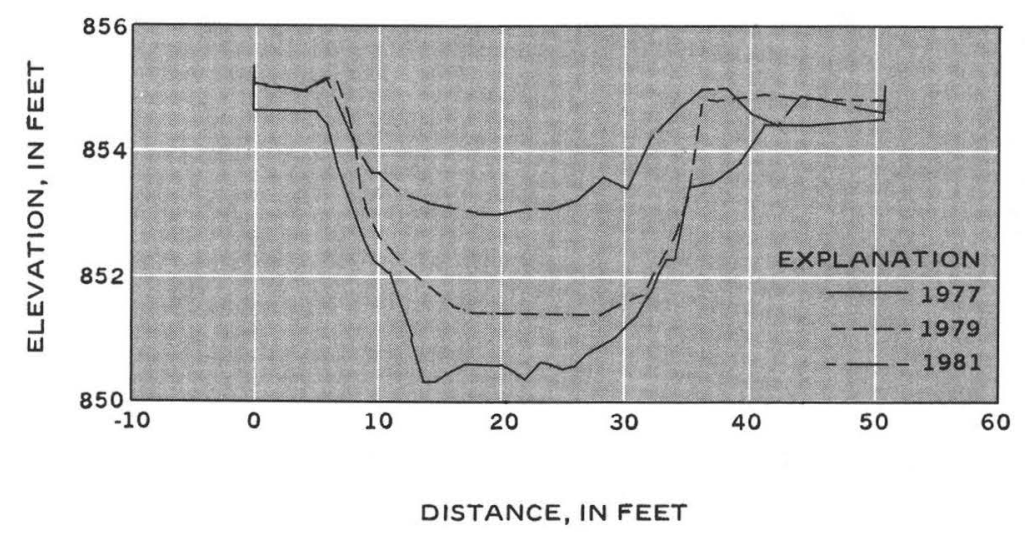

Figure 20. Cross-section plot showing sediment deposition in Pheasant Branch marsh from 1977 to 1981 . 
Hydrographs of the simulated discharge corresponding approximately to the four flood-peak magnitudes for current and for fully urbanized conditions were plotted together for each of the subbasins. These comparative plots are shown in figures 21-38 together with a table of all simulated discharges for each subbasin. In these illustrations the subbasins are named for the channel draining them to correspond with the channels shown in figure 8.

\section{SUMMARY AND CONCLUSIONS}

Four years of streamflow and suspended-sediment data collected in the Pheasant Branch basin provided background data for the present runoff and suspendedsediment conditions in the basin. These data indicated some of the source and sink areas for suspended sediment, and provided calibration information for a rainfallrunoff model.

The U.S. Geological Survey distributed routing rainfall-runoff model was calibrated for the basin upstream from the U.S. Highway 12 gaging station. The calibrated model reasonably simulated storm runoff, despite the fact that the basin size is larger than the basin size normally considered appropriate for use with this model. The most significant problem involved in using the model on a basin of $18.3 \mathrm{mi}^{2}$ was the nonuniform distribution of rainfall. The accuracy of the model in predicting streamflows was better for the whole basin than for the individual subbasins.

Storm runoff from the basin was simulated for 68 years for each of three development conditions:

1. Present conditions-mostly agricultural land use

2. Partial urbanization-including urban development expected to occur over the next 20 or more years

3. Complete urbanization-all of the basin urbanized.

The magnitude of peak discharge at selected recurrence intervals was computed for each of these three conditions at each of the three gaging stations in the area included in the model.
The simulated urbanization increased the flood peaks in all cases. The magnitude of the increase was greater for the smaller, more frequent floods than for the larger, less frequent floods. At U.S. Highway 12 the simulated 2-year flood increases by 99 and 140 percent from present conditions to partial and complete urbanization respectively. The simulated 100 -year flood increases 5 and 23 percent at the same site. For the South Fork at U.S. Highway 14 the simulated increases are 324 and 361 percent for the 2-year flood, and 34 and 44 percent for the 100-year flood. For the North Fork at Airport Road the simulated increases are 32 and 224 percent for the 2-year flood, and 4 and 30 percent for the 100-year flood.

The greatest difference is between present conditions and partial urbanization on the South Fork, because this part of the basin is expected to be developed first. The greatest difference is between partial urbanization and complete urbanization on the North Fork, because little development is projected for this basin for the partial urbanization.

The urban reach of the stream between the U.S. Highway 12 and Century Avenue gaging stations is subject to visible erosion in some spots. However, the suspended-sediment loads observed at the two stations show very little difference. This indicates that sediment removed from areas of obvious erosion is probably redeposited within the same reach.

The reach through Pheasant Branch marsh, between Century Avenue and the mouth, is the site of some visible erosion and visible deposition. The main erosion occurs near Century Avenue; the deposition occurs in the marsh itself. The suspended-sediment loads at the two stations show different time distributions. The suspended-sediment loads normally are reduced significantly during storms, indicating that the marsh is removing suspended sediment from the stream. However, during nonstorm periods, especially during fall and winter, suspended-sediment loads at the mouth are significantly higher than those at Century Avenue. This indicates that some of the suspended sediment stored in the marsh during storms is later released.

Table 7. Percent increase of 2-year flood, bankfull width, and bankfull depth from present conditions to urbanized conditions

\begin{tabular}{|c|c|c|c|c|c|c|}
\hline \multirow[b]{2}{*}{ Site } & \multicolumn{3}{|c|}{ Projected urbanization } & \multicolumn{3}{|c|}{ Complete urbanization } \\
\hline & 2-year flood & (percent increase) & Depth & 2-year flood & (percent increase) & Depth \\
\hline U. S. Highway 12 & 99 & 40 & 30 & 140 & 60 & 40 \\
\hline U. S. Highway 14 & 324 & 110 & 80 & 361 & 110 & 80 \\
\hline Airport Road & 32 & 10 & 10 & 224 & 80 & 60 \\
\hline
\end{tabular}

NOTE: Increase in width or depth are rounded to the nearest 10 percent because there is significant variability among the sites used to determine the average relationships between discharge, width, and depth. 
Periodic resurveys of channel cross sections confirmed the conclusions from the suspended-sediment loads analysis. There was a minor net decrease in the size of the channel between the U.S. Highway 12 and Century Avenue gaging stations. Channel cross sections adjacent to the marsh showed an increase in thalweg elevation from the deposition of sediment. The cross section upstream from the Park Street erosion-control structure showed significant sediment accumulation following dredging of the channel. Sediment trapped at this site can account for most of the reduction in suspendedsediment load between the U.S. Highway 12 and Century Avenue gaging stations.

Significant enlargement of channels having erodible beds and banks would occur as a result of increased storm runoff from urbanization. Nearly all of the channels in the basin are subject to such enlargement. Generalized equations relating channel size to the magnitude of floods at a constant recurrence interval predict that the channels near the gaging stations would be enlarged by 10 to 110 percent in width and 10 to 80 percent in depth at the mean annual flood level by the increased flood peaks. Specifically, near the U.S. Highway 12 gaging station, the channel could be expected to widen by 40 and 60 percent for partial and complete urbanization, respectively. The corresponding increases iì depth would be 30 and 40 percent. Near the Airport Road station the increases in width would be 10 and 80 percent and the increases in depth would be 10 and 60 percent. Near the U.S. Highway 14 gaging station, the increases in width would be 110 percent for both urbanization conditions and the increases in depth would be 80 percent for both conditions.

Flood hydrographs for the approximate 2-, 5-, $10-$, and 25-year floods were simulated for each of 18 subbasins for both current conditions and fully urbanized conditions. These subbasin hydrographs provide the information needed by city planners and engineers when they are evaluating the consequences of development in a small part of the drainage basin. The hydrographs can be used to design storm-water conveyance or detention structures or to evaluate the adequacy of designs proposed by developers.

\section{REFERENCES CITED}

Alley, W. M., and Smith, P. E., 1982, Distributed routing rainfall-runoff model-verision II: U.S. Geological Survey Open-File Report 82-344, 201 p.

City of Middleton, 1982, Master Plan for City of Middleton: Middleton, Wisconsin.
Dane County Regional Planning Commission, 1981, Farmland Preservation Plan, Dane County, Wisconsin: 36 p.

Dunne, Thomas, and Leopold, L. B., 1978, Water in Environmental Planning: W. H. Freeman and Company, San Francisco, Calif., 818 p.

Environmental Data and Information Service, 1978-81, Climatological data-annual summary for Wisconsin: Washington, D.C., U.S. Department of Commerce, v. 83-86.

Glocker, C. L., and Patzer, R. A., 1978, Soil survey of Dane County, Wisconsin: U.S. Department of Agriculture, Soil Conservation Service, 193 p.

Grant, R. S., and Goddard, Gerald, 1980, Channel erosion and sediment transport in Pheasant Branch basin near Middleton, Wisconsin-a preliminary report: U.S. Geological Survey Water-Resources Investigations Open-File Report 80-161, 19 p.

Guy, H. P., and Norman, V. W., 1970, Field methods for measurement of fluvial sediment: U.S. Geological Survey Techniques of Water Resources Investigations, Book 3, Chapter C2, 59 p.

Lai, Chintu, and Onions, C. A., 1976, Computation of unsteady flows in rivers and estuaries by the method of characteristics: U.S. Geological Survey Computer Contribution, $195 \mathrm{p}$.

Lathrop, R. C., and Johnson, C. D., 1979, Dane County Water Quality Plan, Appendix B, Water Quality Conditions: $359 \mathrm{p}$.

Lawrence, C. L., and Holmstrom, B. K., 1972, Floods on Yahara River tributaries, Dane County, Wisconsin: U.S. Geological Survey open-file report, $10 \mathrm{p}$.

Leopold, L. B., and Maddock, Thomas, 1953, The hydraulic geometry of stream channels and some physiographic implications: U.S. Geological Survey Professional Paper $252,55 \mathrm{p}$.

Leopold, L. B., Wolman, M. G., and Miller, J. P., 1964, Fluvial processes in geomorphology: W. H. Freeman and Company, San Francisco, Calif., 522 p.

Porterfield, G., 1972, Computation of fluvial-sediment discharge: U.S. Geological Survey Techniques for Water Resources Investigations, Book 3, Chapter C3, $66 \mathrm{p}$.

U.S. Geological Survey, 1979, Water resources data for Wisconsin, 1978: U.S. Geological Survey WaterResources Data Report WI-78-1, 500 p. -1980 , Water resources data for Wisconsin, 1979: U.S. Geological Survey Water-Data Report WI-79-1, 514 p. 1981, Water resources data for Wisconsin, 1980: U.S. Geological Survey Water-Data Report WI-80-1, $505 \mathrm{p}$.

1982, Water resources data for Wisconsin, 1981: U.S. Geological Survey Water-Data Report WI-81-1, $413 \mathrm{p}$.

U.S. Water Resources Council, 1981, Guidelines for determining flood flow frequency: Water Resources Council Bulletin No. 178, 183 p. 

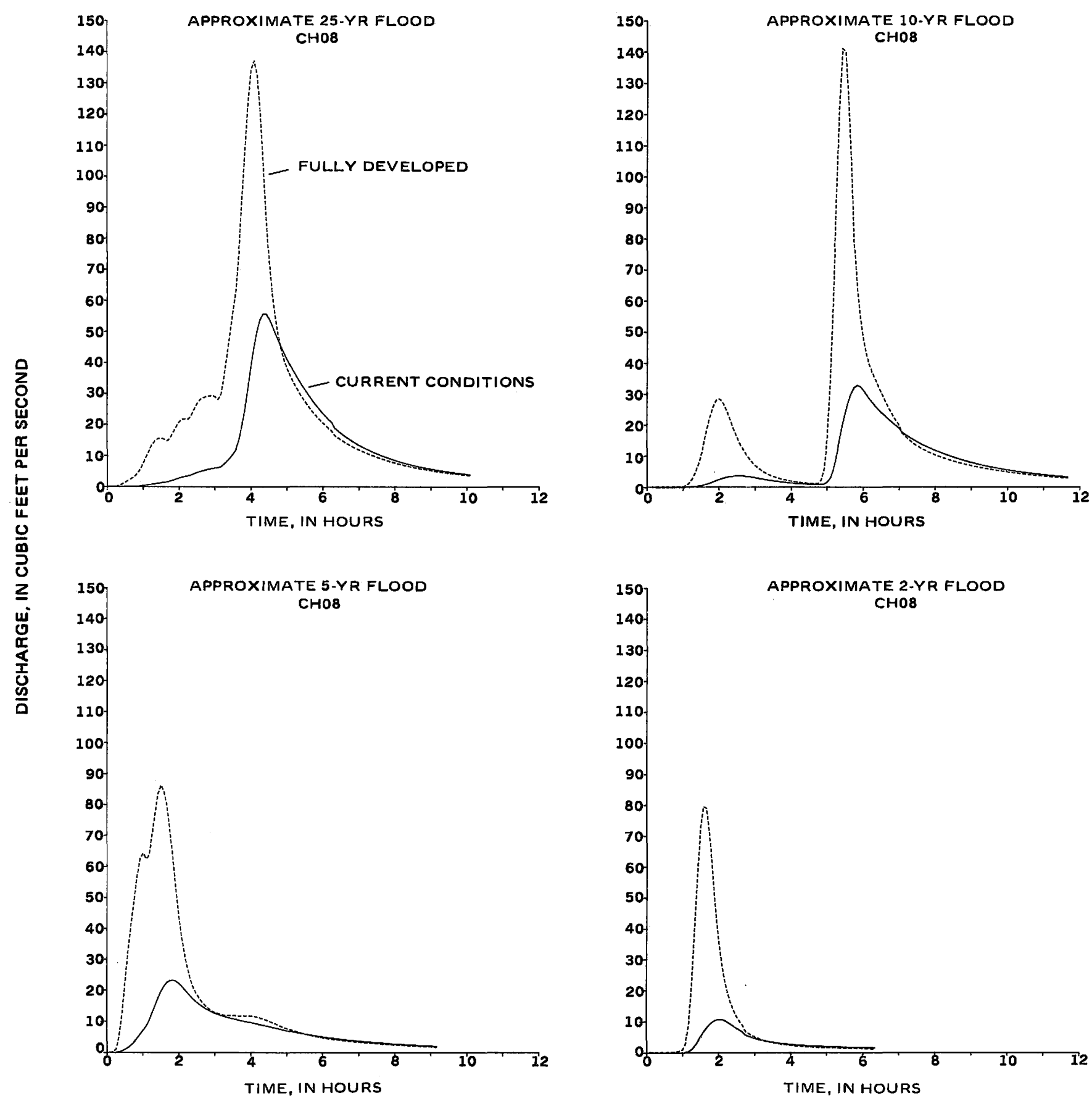

Figure 21. Comparison of approximate 2-, 5-, 10-, and 25-year hydrographs for subbasin CH08 in the Pheasant Branch drainage basin. 
APPROXIMATE 25-YR FLOOD CH08

\begin{tabular}{|c|c|c|c|c|c|c|c|c|c|c|c|}
\hline HR:MN & NOW & URBAN & HR : MN & NOW & URBAN & $H R: M N$ & NOW & URBAN & HR:MN & NOW & URBAN \\
\hline $\begin{array}{l}0: 5 \\
0: 10 \\
0: 15 \\
0: 20 \\
0: 25 \\
0: 30 \\
0: 35 \\
0: 40 \\
0: 45 \\
0: 50 \\
0: 55 \\
1: 0 \\
1: 5 \\
1: 10 \\
1: 15 \\
1: 20 \\
1: 25 \\
1: 30 \\
1: 35 \\
1: 40 \\
1: 45 \\
1: 50 \\
1: 55 \\
2: 0 \\
2: 5 \\
2: 10 \\
2: 15 \\
2: 20 \\
2: 25 \\
2: 30 \\
2: 35\end{array}$ & $\begin{array}{l}0.00 \\
0.00 \\
0.00 \\
0.02 \\
0.03 \\
0.06 \\
0.08 \\
0.11 \\
0.14 \\
0.19 \\
0.27 \\
0.39 \\
0.53 \\
0.69 \\
0.86 \\
1.04 \\
1.20 \\
1.36 \\
1.51 \\
1.65 \\
1.90 \\
2.24 \\
2.58 \\
2.89 \\
3.17 \\
3.39 \\
3.58 \\
3.87 \\
4.26 \\
4.63 \\
4.96\end{array}$ & $\begin{array}{l}0.00 \\
0.02 \\
0.13 \\
0.44 \\
0.92 \\
1.48 \\
2.07 \\
2.64 \\
3.32 \\
4.24 \\
5.67 \\
7.67 \\
9.74 \\
11.75 \\
13.59 \\
14.83 \\
15.49 \\
15.62 \\
15.28 \\
14.75 \\
15.58 \\
17.45 \\
19.19 \\
20.83 \\
21.74 \\
21.86 \\
21.75 \\
22.78 \\
24.83 \\
26.71 \\
28.06\end{array}$ & $\begin{array}{l}2: 40 \\
2: 45 \\
2: 50 \\
2: 55 \\
3: 0 \\
3: 5 \\
3: 10 \\
3: 15 \\
3: 20 \\
3: 25 \\
3: 30 \\
3: 35 \\
3: 40 \\
3: 45 \\
3: 50 \\
3: 55 \\
4: 0 \\
4: 5 \\
4: 10 \\
4: 15 \\
4: 20 \\
4: 25 \\
4: 30 \\
4: 35 \\
4: 40 \\
4: 45 \\
4: 50 \\
4: 55 \\
5: 0 \\
5: 5 \\
5: 10\end{array}$ & $\begin{array}{r}5.24 \\
5.51 \\
5.75 \\
5.97 \\
6.14 \\
6.25 \\
6.61 \\
7.40 \\
8.35 \\
9.41 \\
10.63 \\
12.14 \\
15.00 \\
19.48 \\
24.85 \\
31.51 \\
38.71 \\
45.04 \\
50.23 \\
53.91 \\
55.71 \\
55.70 \\
54.29 \\
52.12 \\
49.76 \\
47.46 \\
45.24 \\
43.15 \\
41.18 \\
39.34 \\
37.58\end{array}$ & $\begin{array}{r}28.72 \\
29.08 \\
29.31 \\
29.43 \\
29.02 \\
28.14 \\
29.65 \\
35.16 \\
42.11 \\
49.58 \\
56.75 \\
63.59 \\
76.02 \\
92.75 \\
108.99 \\
123.86 \\
134.52 \\
137.17 \\
132.74 \\
121.40 \\
105.11 \\
88.06 \\
73.54 \\
63.01 \\
55.04 \\
49.17 \\
44.64 \\
41.11 \\
38.29 \\
35.95 \\
33.94\end{array}$ & $\begin{array}{l}5: 15 \\
5: 20 \\
5: 25 \\
5: 30 \\
5: 35 \\
5: 40 \\
5: 45 \\
5: 50 \\
5: 55 \\
6: 0 \\
6: 5 \\
6: 10 \\
6: 15 \\
6: 20 \\
6: 25 \\
6: 30 \\
6: 35 \\
6: 40 \\
6: 45 \\
6: 50 \\
6: 55 \\
7: 0 \\
7: 5 \\
7: 10 \\
7: 15 \\
7: 20 \\
7: 25 \\
7: 30 \\
7: 35 \\
7: 40 \\
7: 45\end{array}$ & $\begin{array}{l}35.91 \\
34.29 \\
32.74 \\
31.25 \\
29.83 \\
28.47 \\
27.17 \\
25.94 \\
24.76 \\
23.65 \\
22.59 \\
21.58 \\
20.63 \\
18.86 \\
18.05 \\
17.28 \\
16.55 \\
15.85 \\
15.19 \\
14.57 \\
13.98 \\
13.42 \\
12.89 \\
12.38 \\
11.90 \\
11.44 \\
11.01 \\
10.59 \\
10.20 \\
9.83 \\
9.47\end{array}$ & $\begin{array}{l}32.13 \\
30.47 \\
28.92 \\
27.47 \\
26.11 \\
24.84 \\
23.66 \\
22.55 \\
21.51 \\
20.53 \\
19.62 \\
18.75 \\
17.94 \\
16.45 \\
15.77 \\
15.12 \\
14.51 \\
13.92 \\
13.37 \\
12.85 \\
12.35 \\
11.88 \\
11.43 \\
11.01 \\
10.60 \\
10.22 \\
9.85 \\
9.50 \\
9.16 \\
8.84 \\
8.54\end{array}$ & $\begin{array}{r}7: 50 \\
7: 55 \\
8: 0 \\
8: 5 \\
8: 10 \\
8: 15 \\
8: 20 \\
8: 25 \\
8: 30 \\
8: 35 \\
8: 40 \\
8: 45 \\
8: 50 \\
8: 55 \\
9: 0 \\
9: 5 \\
9: 10 \\
9: 15 \\
9: 20 \\
9: 25 \\
9: 30 \\
9: 35 \\
9: 40 \\
9: 45 \\
9: 50 \\
9: 55 \\
10: 0 \\
10: 5\end{array}$ & $\begin{array}{l}9.13 \\
8.81 \\
8.50 \\
8.21 \\
7.93 \\
7.66 \\
7.40 \\
7.16 \\
6.93 \\
6.70 \\
6.49 \\
6.28 \\
6.09 \\
5.90 \\
5.72 \\
5.55 \\
5.38 \\
5.22 \\
5.07 \\
4.92 \\
4.78 \\
4.65 \\
4.52 \\
4.39 \\
4.27 \\
4.15 \\
4.04 \\
3.93\end{array}$ & $\begin{array}{l}8.25 \\
7.97 \\
7.70 \\
7.45 \\
7.21 \\
6.97 \\
6.75 \\
6.54 \\
6.33 \\
6.14 \\
5.95 \\
5.77 \\
5.60 \\
5.43 \\
5.27 \\
5.12 \\
4.97 \\
4.83 \\
4.69 \\
4.56 \\
4.44 \\
4.32 \\
4.20 \\
4.09 \\
3.98 \\
3.87 \\
3.77 \\
3.68\end{array}$ \\
\hline
\end{tabular}

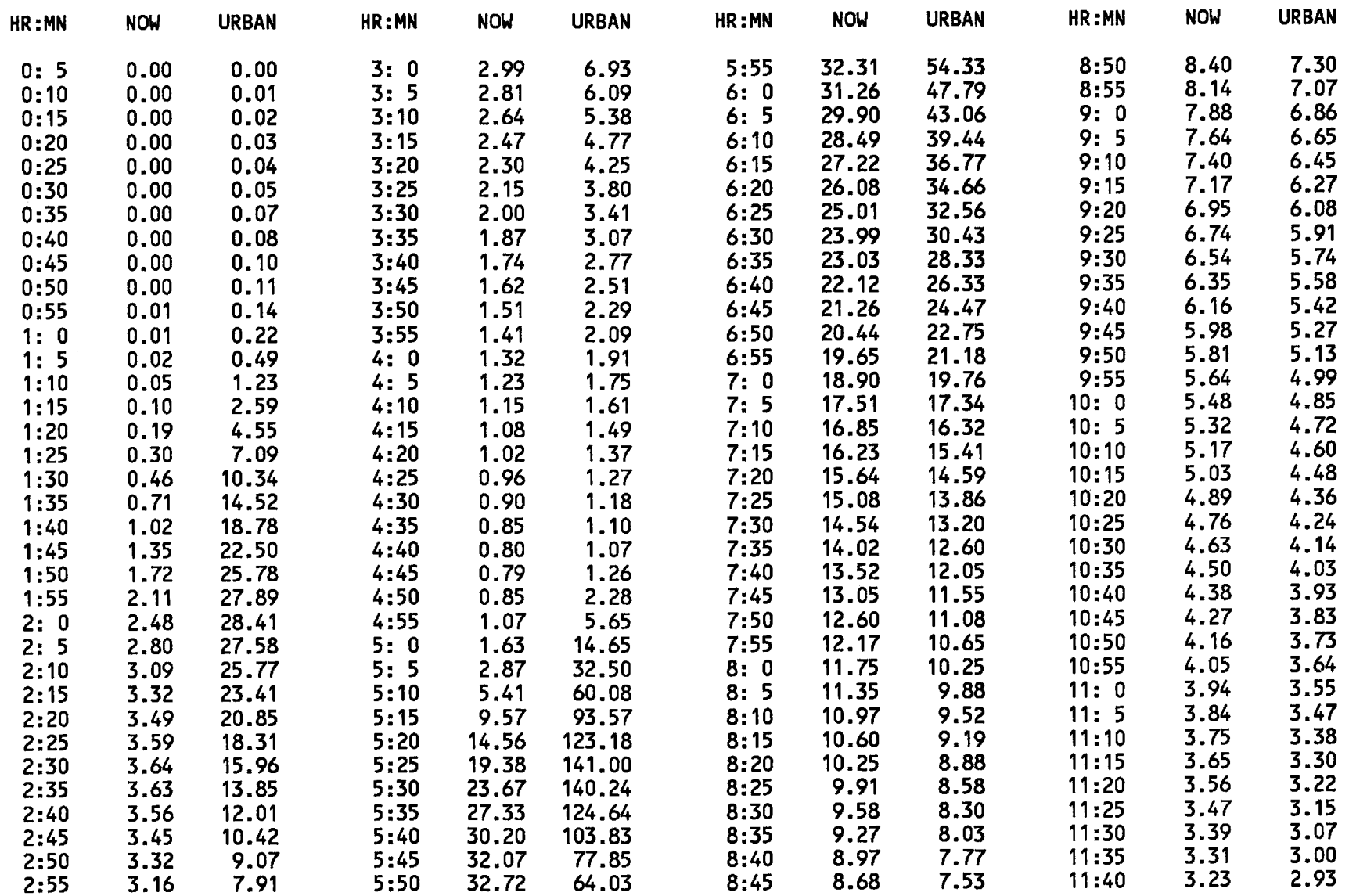


APPROXIMATE 5-YR FLOOD CHO8

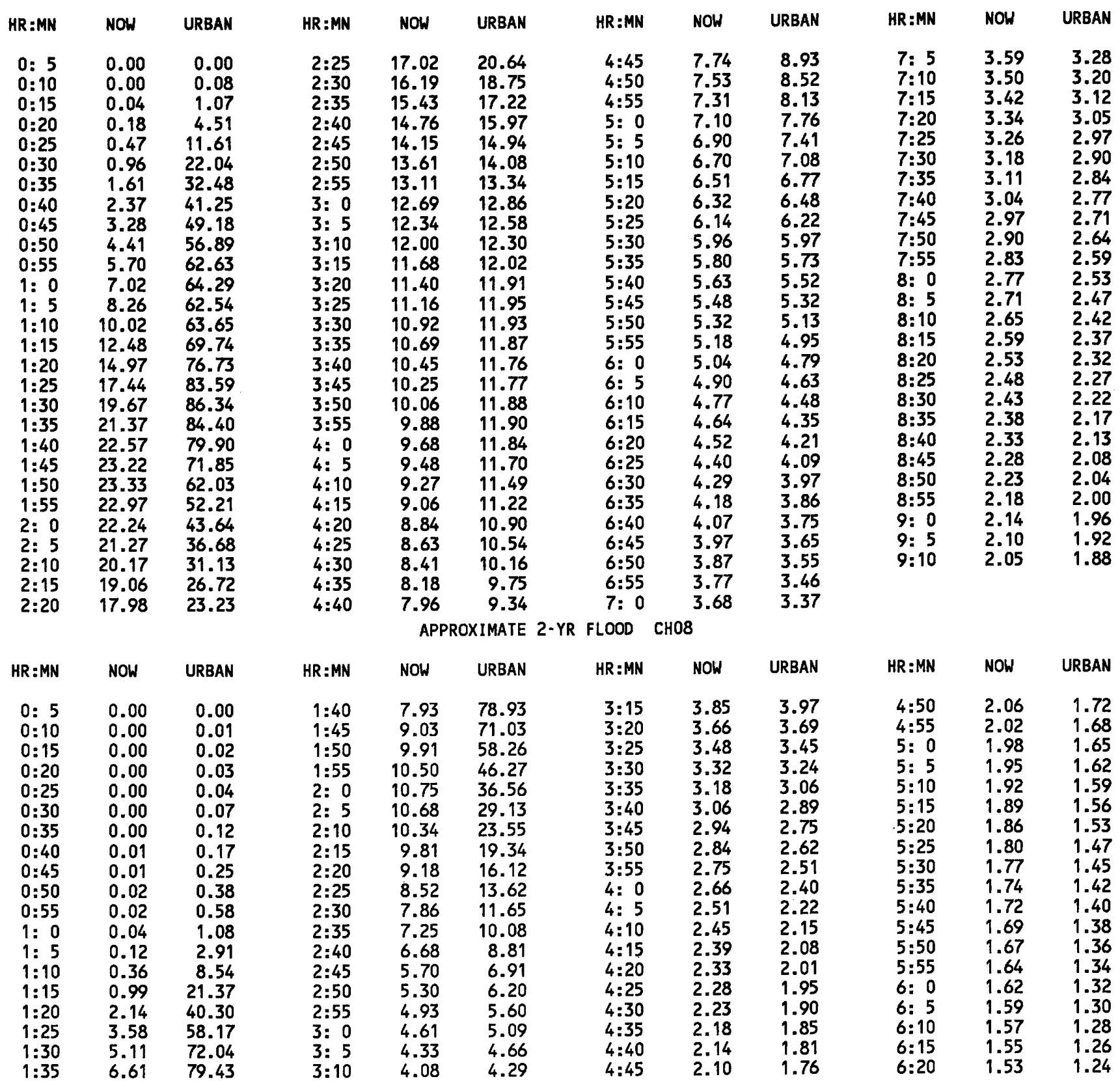



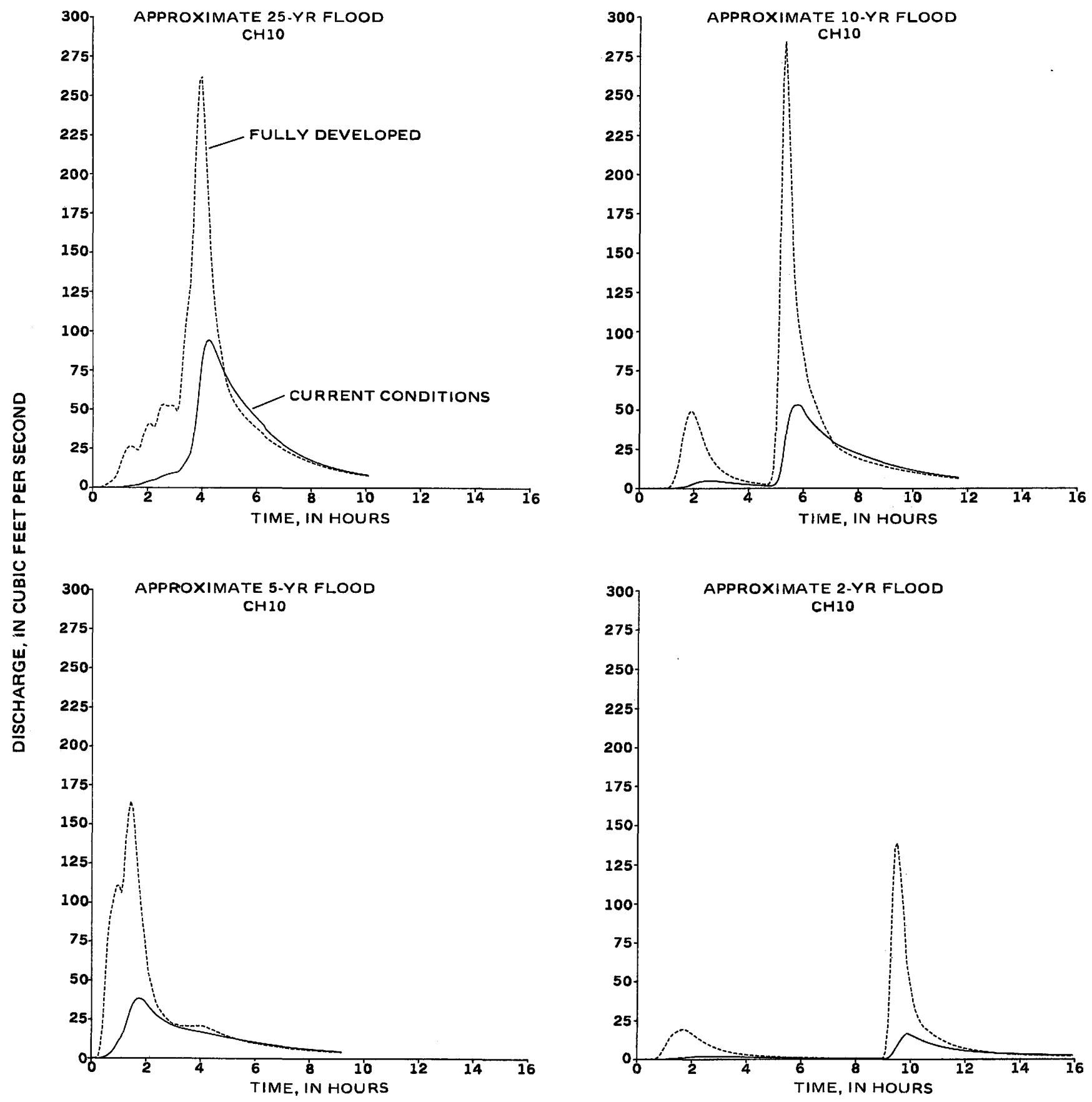

Figure 22. Comparison of approximate 2-, 5-, 10-, and 25-year hydrographs for subbasin CH10 in the Pheasant Branch drainage basin. 
APPROXIMATE 25-YR FLOOD CH10

\begin{tabular}{|c|c|c|c|c|c|c|c|c|c|c|c|}
\hline HR :MN & NOH & URBAN & HR:MN & NOW & URBAN & HR:MN & NOW & URBAN & HR:MN & NOW & URBAN \\
\hline $\begin{array}{l}0: 5 \\
0: 10 \\
0: 15 \\
0: 20 \\
0: 25 \\
0: 30 \\
0: 35 \\
0: 40 \\
0: 45 \\
0: 50 \\
0: 55 \\
1: 0 \\
1: 5 \\
1: 10 \\
1: 15 \\
1: 20 \\
1: 25 \\
1: 30 \\
1: 35 \\
1: 40 \\
1: 45 \\
1: 50 \\
1: 55 \\
2: 0 \\
2: 5 \\
2: 10 \\
2: 15 \\
2: 20\end{array}$ & $\begin{array}{l}0.00 \\
0.00 \\
0.00 \\
0.01 \\
0.02 \\
0.03 \\
0.04 \\
0.06 \\
0.08 \\
0.12 \\
0.19 \\
0.30 \\
0.44 \\
0.61 \\
0.82 \\
1.03 \\
1.25 \\
1.46 \\
1.66 \\
1.87 \\
2.27 \\
2.82 \\
3.38 \\
3.91 \\
4.35 \\
4.70 \\
5.01 \\
5.52\end{array}$ & $\begin{array}{l}0.00 \\
0.01 \\
0.10 \\
0.46 \\
1.14 \\
2.00 \\
2.92 \\
3.82 \\
4.95 \\
6.71 \\
9.76 \\
14.22 \\
18.43 \\
22.06 \\
24.93 \\
26.24 \\
26.43 \\
25.83 \\
24.70 \\
23.82 \\
26.80 \\
32.33 \\
36.77 \\
40.26 \\
41.02 \\
39.69 \\
38.67 \\
42.28\end{array}$ & $\begin{array}{l}2: 40 \\
2: 45 \\
2: 50 \\
2: 55 \\
3: 0 \\
3: 5 \\
3: 10 \\
3: 15 \\
3: 20 \\
3: 25 \\
3: 30 \\
3: 35 \\
3: 40 \\
3: 45 \\
3: 50 \\
3: 55 \\
4: 0 \\
4: 5 \\
4: 10 \\
4: 15 \\
4: 20 \\
4: 25 \\
4: 30 \\
4: 35 \\
4: 40 \\
4: 45 \\
4: 50 \\
4: 55\end{array}$ & $\begin{array}{r}8.10 \\
8.59 \\
9.03 \\
9.43 \\
9.73 \\
9.92 \\
10.72 \\
12.52 \\
14.59 \\
16.76 \\
19.16 \\
22.12 \\
28.83 \\
39.85 \\
52.28 \\
66.87 \\
80.63 \\
89.00 \\
93.14 \\
94.28 \\
93.02 \\
90.31 \\
86.87 \\
83.28 \\
79.66 \\
76.11 \\
72.89 \\
69.94\end{array}$ & $\begin{array}{r}52.51 \\
52.15 \\
52.39 \\
52.69 \\
51.40 \\
48.84 \\
53.95 \\
71.44 \\
90.33 \\
105.60 \\
117.92 \\
129.07 \\
159.89 \\
203.71 \\
234.80 \\
258.87 \\
261.94 \\
236.13 \\
205.33 \\
175.39 \\
147.83 \\
126.90 \\
110.81 \\
98.48 \\
90.08 \\
81.12 \\
71.63 \\
65.32\end{array}$ & $\begin{array}{l}5: 15 \\
5: 20 \\
5: 25 \\
5: 30 \\
5: 35 \\
5: 40 \\
5: 45 \\
5: 50 \\
5: 55 \\
6: 0 \\
6: 5 \\
6: 10 \\
6: 15 \\
6: 20 \\
6: 25 \\
6: 30 \\
6: 35 \\
6: 40 \\
6: 45 \\
6: 50 \\
6: 55 \\
7: 0 \\
7: 5 \\
7: 10 \\
7: 15 \\
7: 20 \\
7: 25 \\
7: 30\end{array}$ & $\begin{array}{l}60.29 \\
58.27 \\
56.35 \\
54.52 \\
52.75 \\
51.04 \\
49.37 \\
47.73 \\
46.13 \\
44.55 \\
43.01 \\
41.50 \\
40.03 \\
37.18 \\
35.82 \\
34.50 \\
33.22 \\
31.98 \\
30.79 \\
29.64 \\
28.53 \\
27.47 \\
26.44 \\
25.46 \\
24.53 \\
23.63 \\
22.76 \\
21.94\end{array}$ & $\begin{array}{l}52.38 \\
50.24 \\
48.29 \\
46.51 \\
44.86 \\
43.31 \\
41.86 \\
40.47 \\
39.15 \\
37.88 \\
36.65 \\
35.46 \\
34.31 \\
32.11 \\
31.06 \\
30.03 \\
29.03 \\
28.07 \\
27.13 \\
26.22 \\
25.34 \\
24.49 \\
23.67 \\
22.87 \\
22.10 \\
21.36 \\
20.65 \\
19.96\end{array}$ & $\begin{array}{l}7: 50 \\
7: 55 \\
8: 0 \\
8: 5 \\
8: 10 \\
8: 15 \\
8: 20 \\
8: 25 \\
8: 30 \\
8: 35 \\
8: 40 \\
8: 45 \\
8: 50 \\
8: 55 \\
9: 0 \\
9: 5 \\
9: 10 \\
9: 15 \\
9: 20 \\
9: 25 \\
9: 30 \\
9: 35 \\
9: 40 \\
9: 45 \\
9: 50 \\
9: 55 \\
10: 0 \\
10: 5\end{array}$ & $\begin{array}{l}18.98 \\
18.32 \\
17.68 \\
17.08 \\
16.50 \\
15.94 \\
15.41 \\
14.91 \\
14.42 \\
13.95 \\
13.51 \\
13.08 \\
12.67 \\
12.28 \\
11.90 \\
11.54 \\
11.19 \\
10.86 \\
10.54 \\
10.23 \\
9.93 \\
9.65 \\
9.38 \\
9.11 \\
8.86 \\
8.62 \\
8.38 \\
8.16\end{array}$ & $\begin{array}{l}17.46 \\
16.89 \\
16.35 \\
15.82 \\
15.32 \\
14.84 \\
14.37 \\
13.92 \\
13.49 \\
13.08 \\
12.68 \\
12.30 \\
11.93 \\
11.58 \\
11.24 \\
10.91 \\
10.60 \\
10.29 \\
10.00 \\
9.72 \\
9.45 \\
9.19 \\
8.94 \\
8.70 \\
8.46 \\
8.24 \\
8.02 \\
7.81\end{array}$ \\
\hline
\end{tabular}

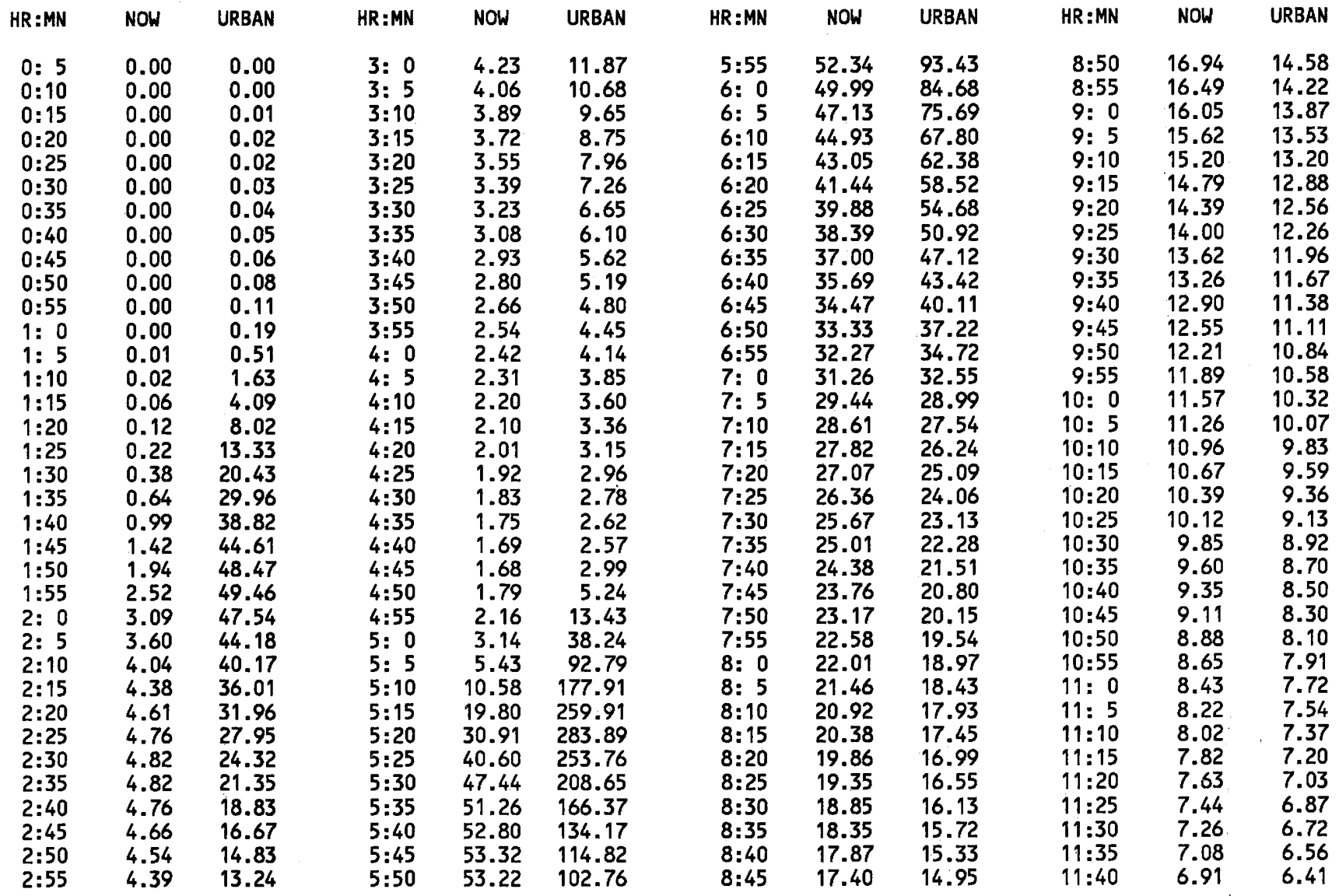


APPROXIMATE 5-YR FLOOD CH10

\begin{tabular}{|c|c|c|c|c|c|c|c|c|c|c|c|}
\hline HR:MN & NOW & URBAN & $H R: M N$ & NOW & URBAN & HR :MN & NOW & URBAN & HR:MN & NOW & URBAN \\
\hline $\begin{array}{l}0: 5 \\
0: 10 \\
0: 15 \\
0: 20 \\
0: 25 \\
0: 30 \\
0: 35 \\
0: 40 \\
0: 45 \\
0: 50 \\
0: 55 \\
1: 0 \\
1: 5 \\
1: 10 \\
1: 15 \\
1: 20 \\
1: 25 \\
1: 30 \\
1: 35 \\
1: 40 \\
1: 45 \\
1: 50 \\
1: 55 \\
2: 0 \\
2: 5 \\
2: 10 \\
2: 15 \\
2: 20\end{array}$ & $\begin{array}{r}0.00 \\
0.00 \\
0.02 \\
0.11 \\
0.39 \\
0.95 \\
1.77 \\
2.83 \\
4.27 \\
6.28 \\
8.79 \\
11.33 \\
13.48 \\
16.79 \\
21.71 \\
26.44 \\
30.92 \\
34.64 \\
36.99 \\
38.26 \\
38.48 \\
37.96 \\
36.94 \\
35.25 \\
33.28 \\
31.54 \\
29.91 \\
28.42\end{array}$ & $\begin{array}{r}0.00 \\
0.05 \\
1.41 \\
8.37 \\
25.73 \\
52.54 \\
76.46 \\
90.23 \\
97.78 \\
104.96 \\
110.67 \\
110.91 \\
106.07 \\
115.66 \\
139.95 \\
156.15 \\
164.52 \\
159.48 \\
143.80 \\
126.63 \\
108.21 \\
92.39 \\
80.38 \\
66.32 \\
54.39 \\
48.51 \\
42.61 \\
36.92\end{array}$ & $\begin{array}{l}2: 25 \\
2: 30 \\
2: 35 \\
2: 40 \\
2: 45 \\
2: 50 \\
2: 55 \\
3: 0 \\
3: 5 \\
3: 10 \\
3: 15 \\
3: 20 \\
3: 25 \\
3: 30 \\
3: 35 \\
3: 40 \\
3: 45 \\
3: 50 \\
3: 55 \\
4: 0 \\
4: 5 \\
4: 10 \\
4: 15 \\
4: 20 \\
4: 25 \\
4: 30 \\
4: 35 \\
4: 40\end{array}$ & $\begin{array}{l}27.17 \\
26.12 \\
25.13 \\
24.20 \\
23.33 \\
22.53 \\
21.78 \\
21.18 \\
20.69 \\
20.21 \\
19.74 \\
19.36 \\
19.06 \\
18.74 \\
18.40 \\
18.07 \\
17.80 \\
17.60 \\
17.36 \\
17.10 \\
16.83 \\
16.55 \\
16.26 \\
15.96 \\
15.66 \\
15.36 \\
15.05 \\
14.75\end{array}$ & $\begin{array}{l}33.27 \\
30.90 \\
28.86 \\
27.07 \\
25.48 \\
24.05 \\
22.78 \\
22.07 \\
21.79 \\
21.39 \\
20.91 \\
20.85 \\
21.12 \\
21.14 \\
20.98 \\
20.67 \\
20.75 \\
21.11 \\
21.19 \\
21.04 \\
20.73 \\
20.29 \\
19.76 \\
19.17 \\
18.54 \\
17.91 \\
17.27 \\
16.64\end{array}$ & $\begin{array}{l}4: 45 \\
4: 50 \\
4: 55 \\
5: 0 \\
5: 5 \\
5: 10 \\
5: 15 \\
5: 20 \\
5: 25 \\
5: 30 \\
5: 35 \\
5: 40 \\
5: 45 \\
5: 50 \\
5: 55 \\
6: 0 \\
6: 5 \\
6: 10 \\
6: 15 \\
6: 20 \\
6: 25 \\
6: 30 \\
6: 35 \\
6: 40 \\
6: 45 \\
6: 50 \\
6: 55 \\
7: 0\end{array}$ & $\begin{array}{l}14.45 \\
14.15 \\
13.85 \\
13.55 \\
13.26 \\
12.97 \\
12.69 \\
12.41 \\
12.13 \\
11.85 \\
11.59 \\
11.32 \\
11.07 \\
10.81 \\
10.56 \\
10.32 \\
10.08 \\
9.85 \\
9.62 \\
9.40 \\
9.18 \\
8.97 \\
8.77 \\
8.57 \\
8.37 \\
8.18 \\
7.99 \\
7.81\end{array}$ & $\begin{array}{l}16.03 \\
15.45 \\
14.89 \\
14.36 \\
13.85 \\
13.37 \\
12.92 \\
12.49 \\
12.08 \\
11.70 \\
11.33 \\
10.99 \\
10.66 \\
10.35 \\
10.06 \\
9.78 \\
9.51 \\
9.25 \\
9.01 \\
8.78 \\
8.55 \\
8.34 \\
8.13 \\
7.93 \\
7.74 \\
7.56 \\
7.38 \\
7.21\end{array}$ & $\begin{array}{l}7: 5 \\
7: 10 \\
7: 15 \\
7: 20 \\
7: 25 \\
7: 30 \\
7: 35 \\
7: 40 \\
7: 45 \\
7: 50 \\
7: 55 \\
8: 0 \\
8: 5 \\
8: 10 \\
8: 15 \\
8: 20 \\
8: 25 \\
8: 30 \\
8: 35 \\
8: 40 \\
8: 45 \\
8: 50 \\
8: 55 \\
9: 0 \\
9: 5 \\
9: 10\end{array}$ & $\begin{array}{l}7.63 \\
7.46 \\
7.29 \\
7.13 \\
6.97 \\
6.81 \\
6.66 \\
6.52 \\
6.37 \\
6.23 \\
6.10 \\
5.97 \\
5.84 \\
5.71 \\
5.59 \\
5.47 \\
5.36 \\
5.25 \\
5.14 \\
5.03 \\
4.93 \\
4.83 \\
4.73 \\
4.63 \\
4.54 \\
4.45\end{array}$ & $\begin{array}{l}7.04 \\
6.88 \\
6.72 \\
6.57 \\
6.43 \\
6.28 \\
6.15 \\
6.01 \\
5.89 \\
5.76 \\
5.64 \\
5.52 \\
5.40 \\
5.29 \\
5.18 \\
5.08 \\
4.97 \\
4.87 \\
4.77 \\
4.68 \\
4.59 \\
4.50 \\
4.41 \\
4.32 \\
4.24 \\
4.16\end{array}$ \\
\hline
\end{tabular}

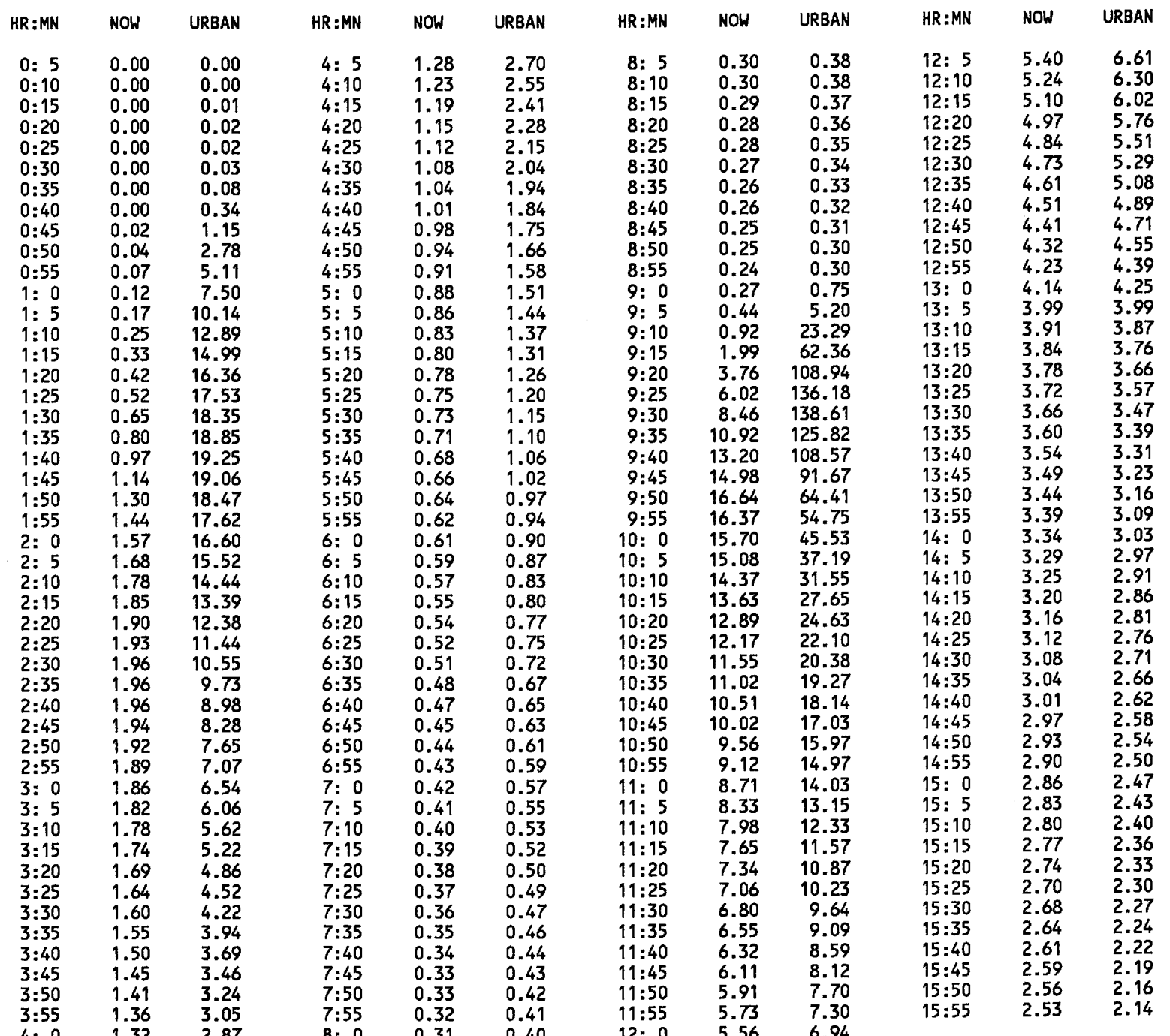



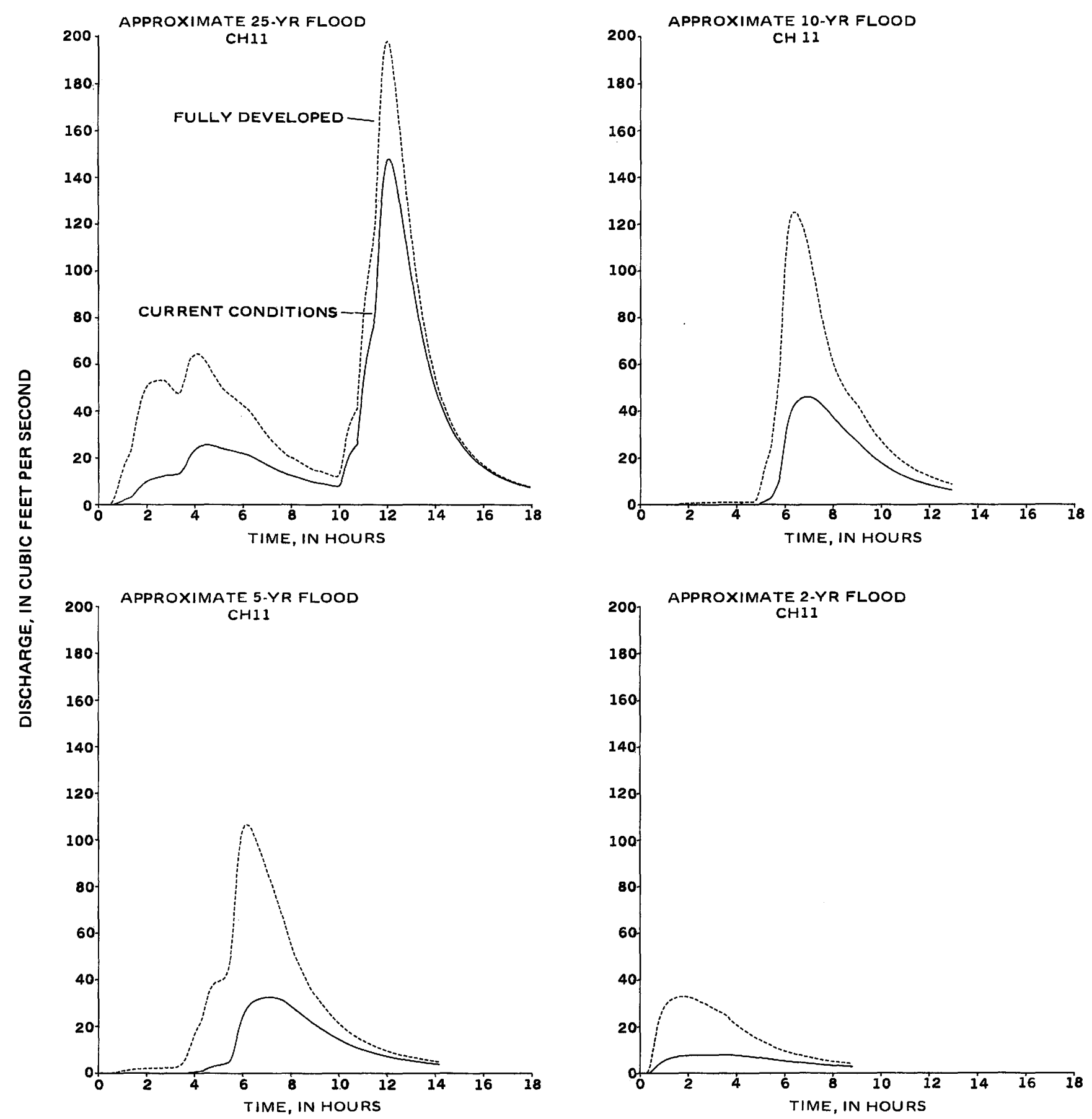

Figure 23. Comparison of approximate 2-, 5-, 10-, and 25-year hydrographs for subbasin CH11 in the Pheasant Branch drainage basin. 


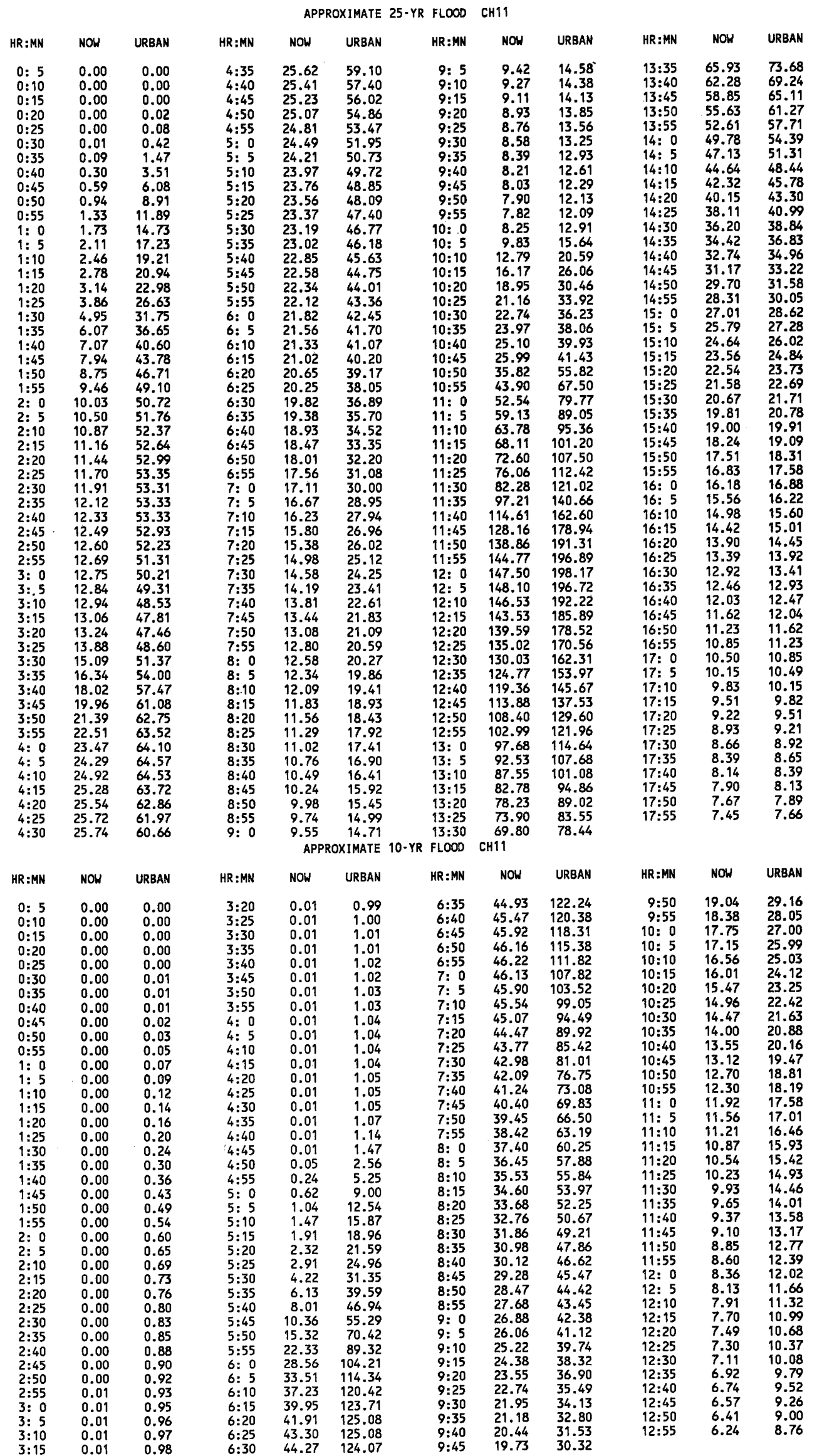


APPROXIMATE 5-YR FLOOD CH11

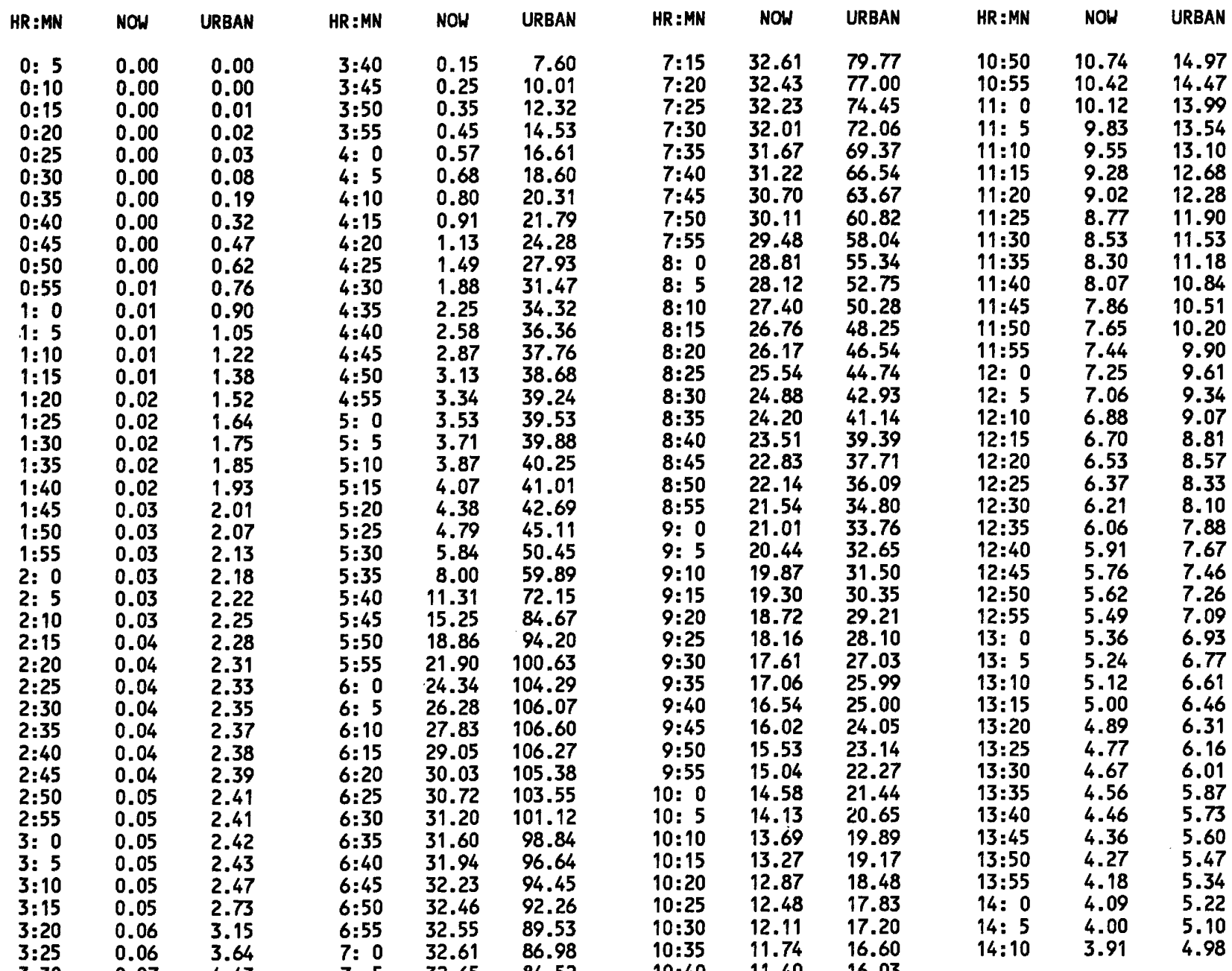

$\begin{array}{lllllllll}3: 30 & 0.07 & 4.43 & 7: 5 & 32.65 & 84.52 & 10: 40 & 11.40 & 16.03 \\ 3: 35 & 0.10 & 5.66 & 7: 10 & 32.65 & 82.12 & 10.45 & 11.06 & 15.49\end{array}$

APPROXIMATE 2-YR FLOOD CH11

\begin{tabular}{|c|c|c|c|c|c|c|c|c|c|c|c|}
\hline HR:MN & NOW & URBAN & HR:MN & NOW & URBAN & HR:MN & NOW & URBAN & $H R: M N$ & NOW & URBAN \\
\hline $\begin{array}{l}0: 5 \\
0: 10 \\
0: 15 \\
0: 20 \\
0: 25 \\
0: 30 \\
0: 35 \\
0: 40 \\
0: 45 \\
0: 50 \\
0: 55 \\
1: 0 \\
1: 5 \\
1: 10 \\
1: 15 \\
1: 20 \\
1: 25 \\
1: 30 \\
1: 35 \\
1: 40 \\
1: 45 \\
1: 50 \\
1: 55 \\
2: 0 \\
2: 5 \\
2: 10 \\
2: 15\end{array}$ & $\begin{array}{l}0.00 \\
0.00 \\
0.00 \\
0.03 \\
0.30 \\
0.99 \\
1.85 \\
2.72 \\
3.52 \\
4.23 \\
4.86 \\
5.39 \\
5.85 \\
6.22 \\
6.53 \\
6.79 \\
7.00 \\
7.18 \\
7.32 \\
7.43 \\
7.52 \\
7.60 \\
7.66 \\
7.71 \\
7.74 \\
7.77 \\
7.80\end{array}$ & $\begin{array}{r}0.00 \\
0.00 \\
0.08 \\
0.60 \\
2.84 \\
7.34 \\
12.53 \\
17.28 \\
21.20 \\
24.29 \\
26.67 \\
28.46 \\
29.79 \\
30.78 \\
31.50 \\
32.02 \\
32.39 \\
32.66 \\
32.83 \\
32.94 \\
32.97 \\
32.95 \\
32.87 \\
32.73 \\
32.53 \\
32.27 \\
31.94\end{array}$ & $\begin{array}{l}2: 20 \\
2: 25 \\
2: 30 \\
2: 35 \\
2: 40 \\
2: 45 \\
2: 50 \\
2: 55 \\
3: 00 \\
3: 5 \\
3: 10 \\
3: 15 \\
3: 20 \\
3: 25 \\
3: 30 \\
3: 35 \\
3: 40 \\
3: 45 \\
3: 50 \\
3: 55 \\
4: 0 \\
4: 5 \\
4: 10 \\
4: 15 \\
4: 20 \\
4: 25 \\
4: 30\end{array}$ & $\begin{array}{l}7.81 \\
7.83 \\
7.83 \\
7.85 \\
7.88 \\
7.90 \\
7.90 \\
7.90 \\
7.91 \\
7.93 \\
7.93 \\
7.93 \\
7.93 \\
7.93 \\
7.92 \\
7.90 \\
7.87 \\
7.78 \\
7.73 \\
7.67 \\
7.60 \\
7.53 \\
7.45 \\
7.37 \\
7.29 \\
7.20 \\
7.11\end{array}$ & $\begin{array}{l}31.56 \\
31.11 \\
30.62 \\
30.27 \\
30.02 \\
29.63 \\
29.13 \\
28.55 \\
28.10 \\
27.74 \\
27.26 \\
26.68 \\
26.22 \\
25.85 \\
25.36 \\
24.79 \\
24.17 \\
22.85 \\
22.17 \\
21.49 \\
20.83 \\
20.17 \\
19.53 \\
18.90 \\
18.30 \\
17.71 \\
17.14\end{array}$ & $\begin{array}{l}4: 35 \\
4: 40 \\
4: 45 \\
4: 50 \\
4: 55 \\
5: 0 \\
5: 5 \\
5: 10 \\
5: 15 \\
5: 20 \\
5: 25 \\
5: 30 \\
5: 35 \\
5: 40 \\
5: 45 \\
5: 50 \\
5: 55 \\
6: 0 \\
6: 5 \\
6: 10 \\
6: 15 \\
6: 20 \\
6: 25 \\
6: 30 \\
6: 35 \\
6: 40 \\
6: 45\end{array}$ & $\begin{array}{l}7.02 \\
6.93 \\
6.83 \\
6.73 \\
6.63 \\
6.53 \\
6.43 \\
6.33 \\
6.23 \\
6.13 \\
6.03 \\
5.93 \\
5.73 \\
5.63 \\
5.53 \\
5.43 \\
5.34 \\
5.24 \\
5.15 \\
5.05 \\
4.96 \\
4.87 \\
4.78 \\
4.69 \\
4.61 \\
4.52 \\
4.44\end{array}$ & $\begin{array}{c}16.59 \\
16.06 \\
15.55 \\
15.06 \\
14.59 \\
14.13 \\
13.69 \\
13.27 \\
12.86 \\
12.47 \\
12.09 \\
11.73 \\
11.05 \\
10.72 \\
10.41 \\
10.11 \\
9.83 \\
9.55 \\
9.28 \\
9.02 \\
8.77 \\
8.53 \\
8.30 \\
8.08 \\
7.86 \\
7.65 \\
7.45\end{array}$ & $\begin{array}{l}6: 50 \\
6: 55 \\
7: 0 \\
7: 5 \\
7: 10 \\
7: 15 \\
7: 20 \\
7: 25 \\
7: 30 \\
7: 35 \\
7: 40 \\
7: 45 \\
7: 50 \\
7: 55 \\
8: 0 \\
8: 5 \\
8: 10 \\
8: 15 \\
8: 20 \\
8: 25 \\
8: 30 \\
8: 35 \\
8: 40 \\
8: 45 \\
8: 50\end{array}$ & $\begin{array}{l}4.35 \\
4.27 \\
4.20 \\
4.12 \\
4.04 \\
3.97 \\
3.89 \\
3.75 \\
3.68 \\
3.61 \\
3.55 \\
3.48 \\
3.42 \\
3.36 \\
3.30 \\
3.24 \\
3.18 \\
3.12 \\
3.07 \\
3.01 \\
2.96 \\
2.91 \\
2.85 \\
2.80 \\
2.76\end{array}$ & $\begin{array}{l}7.26 \\
7.07 \\
6.89 \\
6.72 \\
6.55 \\
6.39 \\
6.23 \\
5.93 \\
5.78 \\
5.65 \\
5.51 \\
5.38 \\
5.26 \\
5.13 \\
5.02 \\
4.90 \\
4.79 \\
4.68 \\
4.58 \\
4.48 \\
4.38 \\
4.28 \\
4.19 \\
4.10 \\
4.02\end{array}$ \\
\hline
\end{tabular}



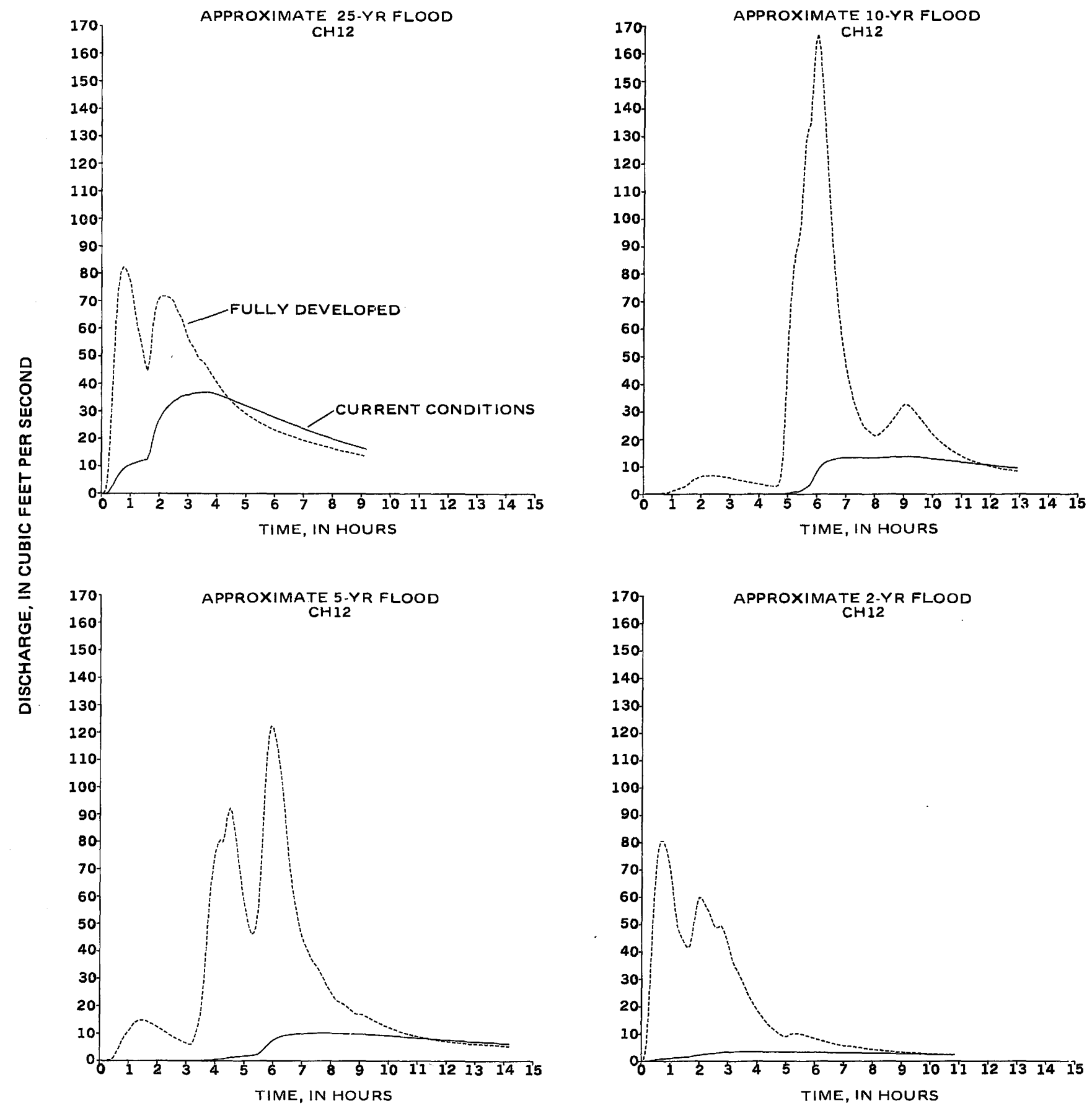

Figure 24. Comparison of approximate 2-, 5-, 10-, and 25-year hydrographs for subbasin $\mathrm{CH} 12$ in the Pheasant Branch drainage basin. 
APPROXIMATE 25-YR FLOOD CH12

\begin{tabular}{|c|c|c|c|c|c|c|c|c|c|c|c|}
\hline HR:MN & NOW & URBAN & $H R: M N$ & NOW & URBAN & $H R: M N$ & NOW & URBAN & HR:MN & NOW & URBAN \\
\hline $\begin{array}{l}0: 5 \\
0: 10 \\
0: 15 \\
0: 20 \\
0: 25 \\
0: 30 \\
0: 35 \\
0: 40 \\
0: 45 \\
0: 50 \\
0: 55 \\
1: 0 \\
1: 5 \\
1: 10 \\
1: 15 \\
1: 20 \\
1: 25 \\
1: 30 \\
1: 35 \\
1: 40 \\
1: 45 \\
1: 50 \\
1: 55 \\
2: 0 \\
2: 5 \\
2: 10 \\
2: 15 \\
2: 20\end{array}$ & $\begin{array}{r}0.00 \\
0.02 \\
0.49 \\
1.79 \\
3.40 \\
5.09 \\
6.59 \\
7.81 \\
8.77 \\
9.51 \\
10.07 \\
10.49 \\
10.87 \\
11.23 \\
11.56 \\
11.89 \\
12.13 \\
12.30 \\
12.52 \\
14.57 \\
18.58 \\
22.19 \\
24.96 \\
27.08 \\
28.75 \\
30.08 \\
31.20 \\
32.16\end{array}$ & $\begin{array}{r}0.02 \\
1.38 \\
9.91 \\
26.71 \\
45.41 \\
62.60 \\
74.48 \\
80.43 \\
82.25 \\
81.54 \\
79.56 \\
76.62 \\
71.56 \\
65.21 \\
60.39 \\
56.53 \\
52.23 \\
47.93 \\
44.78 \\
48.62 \\
58.64 \\
65.80 \\
69.49 \\
71.18 \\
71.79 \\
71.86 \\
71.67 \\
71.37\end{array}$ & $\begin{array}{l}2: 25 \\
2: 30 \\
2: 35 \\
2: 40 \\
2: 45 \\
2: 50 \\
2: 55 \\
3: 0 \\
3: 5 \\
3: 10 \\
3: 15 \\
3: 20 \\
3: 25 \\
3: 30 \\
3: 35 \\
3: 40 \\
3: 45 \\
3: 50 \\
3: 55 \\
4: 0 \\
4: 5 \\
4: 10 \\
4: 15 \\
4: 20 \\
4: 25 \\
4: 30 \\
4: 35 \\
4: 40\end{array}$ & $\begin{array}{l}33.03 \\
33.82 \\
34.31 \\
34.86 \\
35.42 \\
35.75 \\
35.93 \\
35.99 \\
36.21 \\
36.52 \\
36.65 \\
36.67 \\
36.82 \\
37.05 \\
37.10 \\
37.04 \\
36.89 \\
36.69 \\
36.45 \\
36.18 \\
35.88 \\
35.57 \\
35.25 \\
34.92 \\
34.58 \\
34.24 \\
33.89 \\
33.53\end{array}$ & $\begin{array}{l}70.85 \\
69.73 \\
67.16 \\
65.38 \\
63.98 \\
61.70 \\
59.03 \\
56.25 \\
54.50 \\
53.40 \\
51.75 \\
49.87 \\
48.83 \\
48.31 \\
47.24 \\
45.91 \\
44.47 \\
43.03 \\
41.62 \\
40.27 \\
39.00 \\
37.80 \\
36.68 \\
35.63 \\
34.64 \\
33.71 \\
32.84 \\
32.02\end{array}$ & $\begin{array}{l}4: 45 \\
4: 50 \\
4: 55 \\
5: 0 \\
5: 5 \\
5: 10 \\
5: 15 \\
5: 20 \\
5: 25 \\
5: 30 \\
5: 35 \\
5: 40 \\
5: 45 \\
5: 50 \\
5: 55 \\
6: 0 \\
6: 5 \\
6: 10 \\
6: 15 \\
6: 20 \\
6: 25 \\
6: 30 \\
6: 35 \\
6: 40 \\
6: 45 \\
6: 50 \\
6: 55 \\
7: 0\end{array}$ & $\begin{array}{l}33.18 \\
32.82 \\
32.46 \\
32.10 \\
31.74 \\
31.38 \\
31.02 \\
30.66 \\
30.30 \\
29.95 \\
29.59 \\
29.24 \\
28.88 \\
28.53 \\
28.18 \\
27.83 \\
27.48 \\
27.13 \\
26.79 \\
26.45 \\
26.10 \\
25.76 \\
25.43 \\
25.09 \\
24.76 \\
24.43 \\
24.10 \\
23.77\end{array}$ & $\begin{array}{l}31.24 \\
30.51 \\
29.82 \\
29.16 \\
28.54 \\
27.95 \\
27.38 \\
26.85 \\
26.33 \\
25.84 \\
25.37 \\
24.92 \\
24.49 \\
24.07 \\
23.67 \\
23.28 \\
22.90 \\
22.54 \\
22.19 \\
21.85 \\
21.52 \\
21.20 \\
20.89 \\
20.59 \\
20.29 \\
20.00 \\
19.72 \\
19.44\end{array}$ & $\begin{array}{l}7: 5 \\
7: 10 \\
7: 15 \\
7: 20 \\
7: 25 \\
7: 30 \\
7: 35 \\
7: 40 \\
7: 45 \\
7: 50 \\
7: 55 \\
8: 0 \\
8: 5 \\
8: 10 \\
8: 15 \\
8: 20 \\
8: 25 \\
8: 30 \\
8: 35 \\
8: 40 \\
8: 45 \\
8: 50 \\
8: 55 \\
9: 0 \\
9: 5 \\
9: 10\end{array}$ & $\begin{array}{l}23.44 \\
23.12 \\
22.80 \\
22.48 \\
22.17 \\
21.86 \\
21.55 \\
21.24 \\
20.94 \\
20.63 \\
20.34 \\
20.04 \\
19.75 \\
19.46 \\
19.18 \\
18.90 \\
18.62 \\
18.35 \\
18.08 \\
17.81 \\
17.54 \\
17.28 \\
17.03 \\
16.77 \\
16.52 \\
16.28\end{array}$ & $\begin{array}{l}19.17 \\
18.91 \\
18.65 \\
18.40 \\
18.15 \\
17.90 \\
17.66 \\
17.42 \\
17.19 \\
16.96 \\
16.73 \\
16.51 \\
16.29 \\
16.07 \\
15.86 \\
15.65 \\
15.44 \\
15.24 \\
15.04 \\
14.84 \\
14.64 \\
14.45 \\
14.26 \\
14.07 \\
13.88 \\
13.70\end{array}$ \\
\hline
\end{tabular}

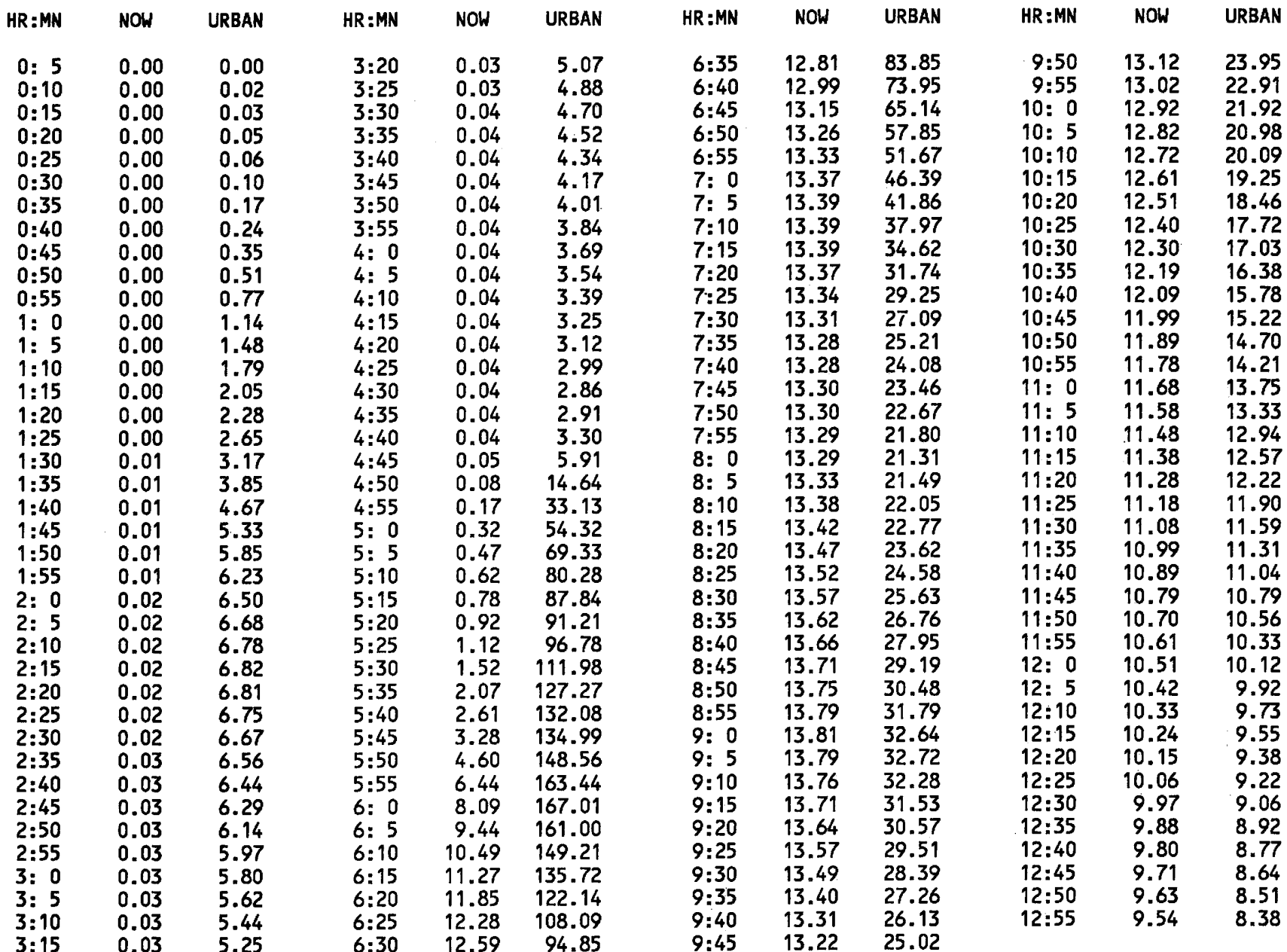


APPROXIMATE 5-YR FLOOD CH12

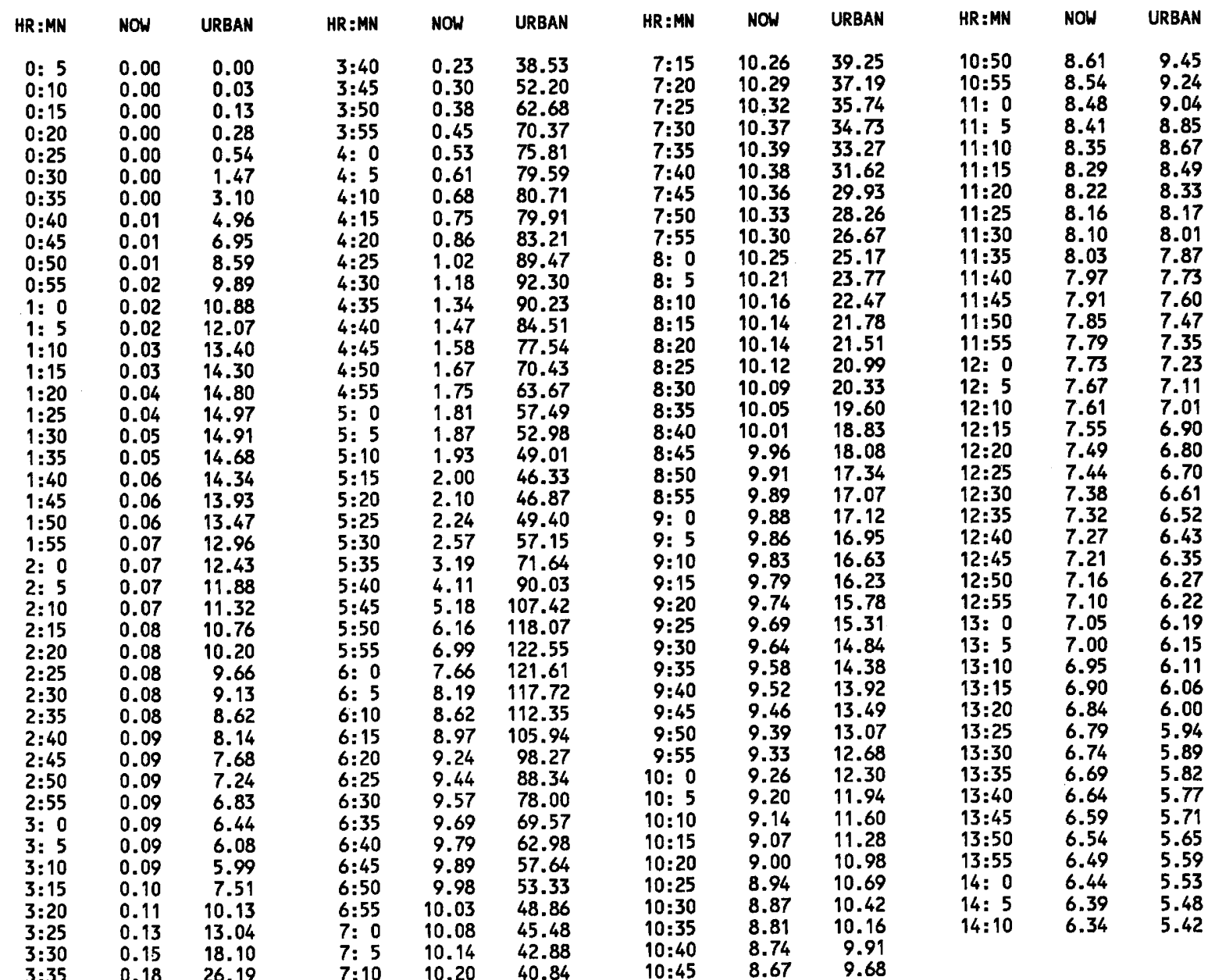

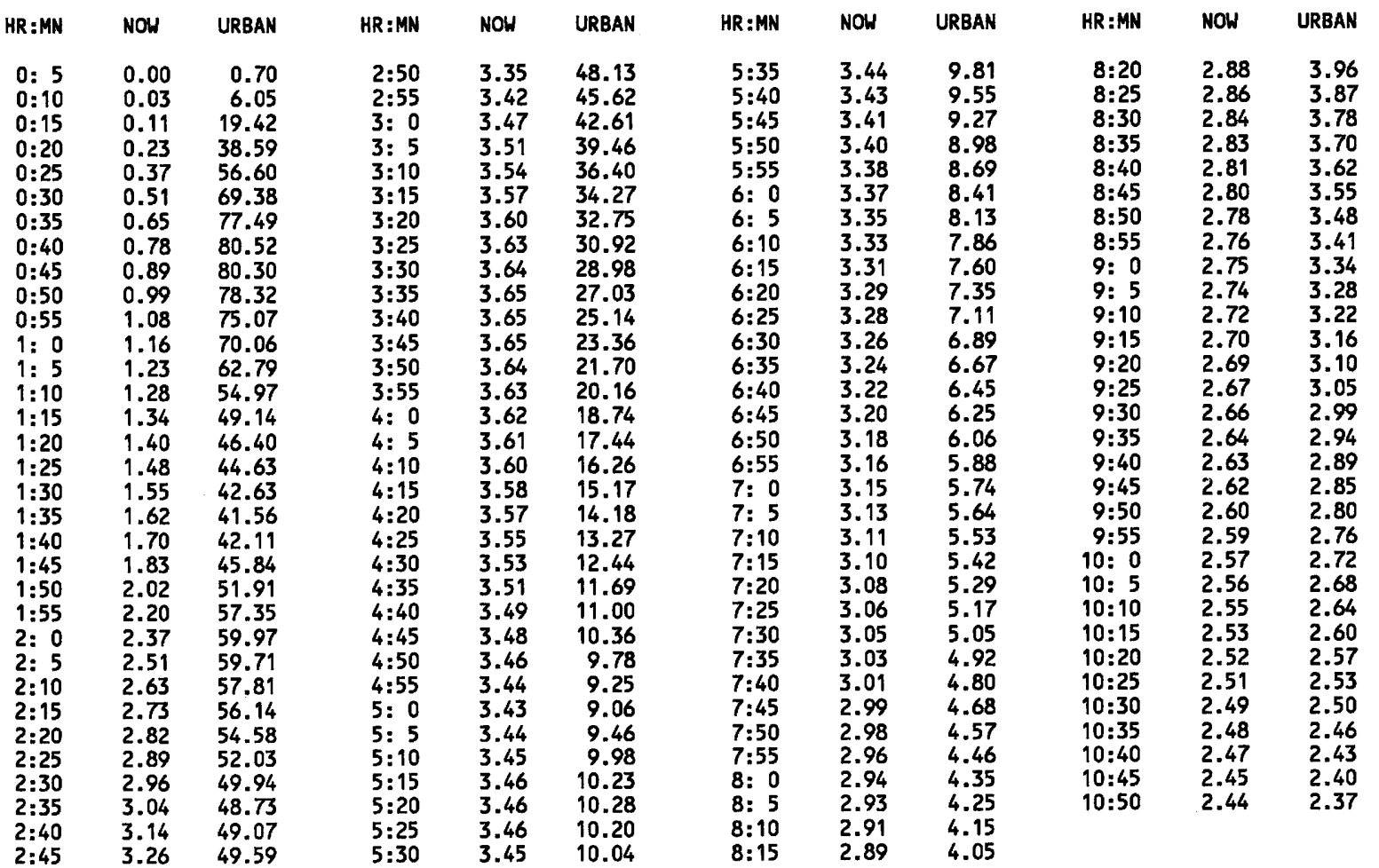



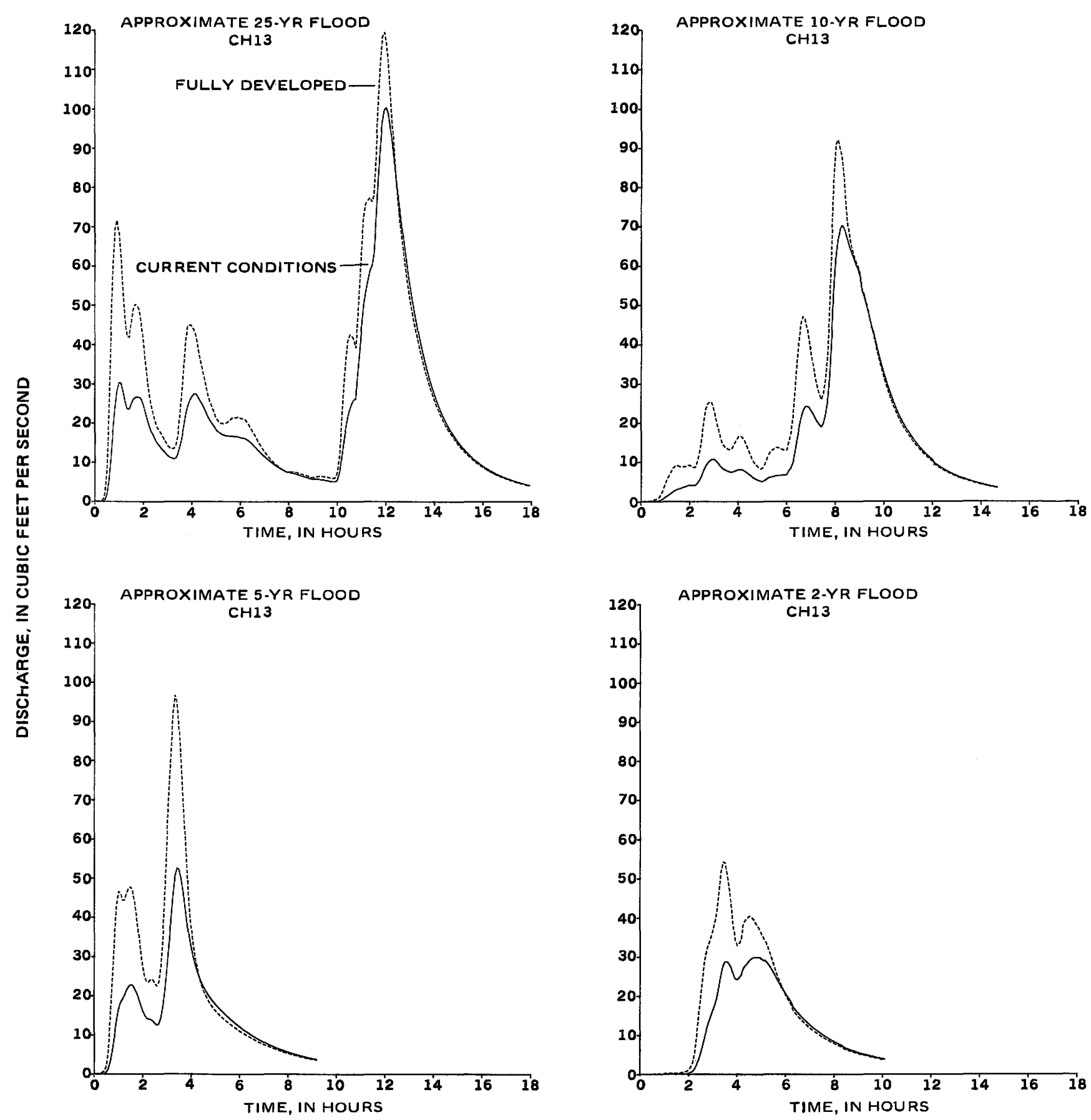

Figure 25. Comparison of approximate 2-, 5-, 10-, and 25-year hydrographs for subbasin CH13 in the Pheasant Branch drainage basin. 


\begin{tabular}{|c|c|c|c|c|}
\hline & & & & APP \\
\hline HR:MN & NOW & URBAN & HR:MN & NOW \\
\hline $0: 5$ & 0.00 & 0.00 & $4: 35$ & 22.77 \\
\hline $\begin{array}{l}0: 10 \\
0: 15\end{array}$ & $\begin{array}{l}0.01 \\
0.03\end{array}$ & $\begin{array}{l}0.04 \\
0.13\end{array}$ & $\begin{array}{l}4: 40 \\
4: 45\end{array}$ & $\begin{array}{l}21.62 \\
20.71\end{array}$ \\
\hline $0: 20$ & 0.08 & 0.38 & $4: 50$ & 19.99 \\
\hline $0: 25$ & 0.42 & 1.91 & $4: 55$ & 19.22 \\
\hline $0: 30$ & 1.74 & 7.88 & $5: 0$ & 18.42 \\
\hline $\begin{array}{l}0: 35 \\
0: 40\end{array}$ & & 22.25 & 5:5 & $\begin{array}{l}17.83 \\
17.39\end{array}$ \\
\hline $\begin{array}{l}0: 40 \\
0: 45\end{array}$ & $\begin{array}{l}11.10 \\
17.81\end{array}$ & $\begin{array}{l}42.94 \\
60.05\end{array}$ & $5: 15$ & $\begin{array}{l}17.39 \\
17.08\end{array}$ \\
\hline $0: 50$ & 23.85 & 69.25 & $5: 20$ & 16.87 \\
\hline $\begin{array}{l}0: 55 \\
1: 0\end{array}$ & $\begin{array}{l}28.29 \\
30.38\end{array}$ & $\begin{array}{l}71.66 \\
68.53\end{array}$ & $\begin{array}{l}5: 25 \\
5: 30\end{array}$ & $\begin{array}{l}16.74 \\
16.68\end{array}$ \\
\hline $1: 5$ & 30.11 & 61.92 & $5: 35$ & 16.67 \\
\hline $1: 10$ & 28.03 & 53.75 & $5: 40$ & 16.71 \\
\hline $\begin{array}{l}1: 15 \\
1: 20\end{array}$ & $\begin{array}{l}25.54 \\
23.73\end{array}$ & $\begin{array}{l}46.64 \\
42.04\end{array}$ & $\begin{array}{l}5: 45 \\
5: 50\end{array}$ & $\begin{array}{l}16.57 \\
16.50\end{array}$ \\
\hline $\begin{array}{l}1: 20 \\
1: 25\end{array}$ & 23.62 & $\begin{array}{l}42.04 \\
41.88\end{array}$ & $5: 55$ & 16.48 \\
\hline $\begin{array}{l}1: 30 \\
1: 35\end{array}$ & 24.86 & $\begin{array}{l}45.36 \\
48.89\end{array}$ & $\begin{array}{l}6: 0 \\
6: 5\end{array}$ & $\begin{array}{l}16.28 \\
16.16\end{array}$ \\
\hline $\begin{array}{l}1: 53 \\
1: 40\end{array}$ & $\begin{array}{l}20.07 \\
26.58\end{array}$ & $\begin{array}{l}48.89 \\
50.28\end{array}$ & $\begin{array}{l}0: 3 \\
6: 10\end{array}$ & $\begin{array}{l}10.10 \\
16.09\end{array}$ \\
\hline $1: 45$ & 26.62 & 49.90 & $6: 15$ & 15.85 \\
\hline $\begin{array}{l}1: 50 \\
1: 55\end{array}$ & 26.60 & $\begin{array}{l}48.78 \\
45.49\end{array}$ & $\begin{array}{l}6: 20 \\
6: 25\end{array}$ & 15.48 \\
\hline $\begin{array}{l}1: 55 \\
2: 0\end{array}$ & 24.68 & 40.31 & $6: 30$ & $\begin{array}{l}13.04 \\
14.54\end{array}$ \\
\hline 2: 5 & 22.83 & 35.27 & $6: 35$ & 14.01 \\
\hline $2: 10$ & 20.98 & 30.86 & $6: 40$ & 13.48 \\
\hline $\begin{array}{l}2: 15 \\
2: 20\end{array}$ & 19.22 & $\begin{array}{l}27.00 \\
2.0\end{array}$ & $\begin{array}{l}6: 45 \\
6: 50\end{array}$ & 12.94 \\
\hline $\begin{array}{l}2: 20 \\
2: 25\end{array}$ & $\begin{array}{l}17.80 \\
16.67\end{array}$ & $\begin{array}{l}24.19 \\
22.14\end{array}$ & $6: 55$ & $\begin{array}{l}12.42 \\
11.91\end{array}$ \\
\hline $2: 30$ & 15.59 & 20.21 & $7: 0$ & 11.42 \\
\hline $2: 35$ & 14.75 & 18.86 & $7: 5$ & 10.96 \\
\hline $2: 40$ & 14.12 & 17.96 & $7: 10$ & 10.51 \\
\hline $2: 45$ & $\begin{array}{l}13.48 \\
12.85\end{array}$ & 16.99 & $\begin{array}{l}7: 15 \\
7: 20\end{array}$ & $\begin{array}{r}10.09 \\
9.70\end{array}$ \\
\hline $\begin{array}{l}2: 50 \\
2: 55\end{array}$ & $\begin{array}{l}12.85 \\
12.26\end{array}$ & $\begin{array}{l}16.02 \\
15.08\end{array}$ & $\begin{array}{l}7: 20 \\
7: 25\end{array}$ & $\begin{array}{l}9.70 \\
9.32\end{array}$ \\
\hline $3: 0$ & 11.69 & 14.18 & $7: 30$ & 8.97 \\
\hline $3: 5$ & 11.31 & 13.68 & $7: 35$ & 8.63 \\
\hline $3: 10$ & 11.07 & 13.47 & $7: 40$ & 8.32 \\
\hline $3: 15$ & 10.95 & 13.51 & $7: 45$ & 8.02 \\
\hline $3: 20$ & 11.08 & 14.16 & $7: 50$ & 7.74 \\
\hline $3: 25$ & 11.99 & 16.59 & $7: 55$ & 7.57 \\
\hline $3: 30$ & 13.87 & 21.47 & $8: 0$ & 7.48 \\
\hline $3: 35$ & 16.06 & 27.18 & $8: 5$ & 7.37 \\
\hline $3: 40$ & 18.99 & 34.53 & $8: 10$ & 7.24 \\
\hline $3: 45$ & 22.21 & 41.66 & $8: 15$ & 7.10 \\
\hline $3: 50$ & 24.37 & 44.66 & $8: 20$ & 6.94 \\
\hline $3: 55$ & 25.81 & 45.12 & $8: 25$ & 6.78 \\
\hline $4: 0$ & 26.83 & 44.73 & $8: 30$ & 6.62 \\
\hline $4: 5$ & 27.42 & 43.87 & $8: 35$ & 6.45 \\
\hline $4: 10$ & 27.36 & 41.99 & $8: 40$ & 6.29 \\
\hline $4: 15$ & 26.63 & 38.94 & $8: 45$ & 6.13 \\
\hline $4: 20$ & 25.77 & 36.27 & $8: 50$ & 5.96 \\
\hline $4: 25$ & 24.94 & 34.11 & $8: 55$ & 5.81 \\
\hline $4: 30$ & 23.90 & 31.76 & $9: 0$ & 5.74 \\
\hline & & & & APP \\
\hline HR:MN & NOW & URBAN & HR:MN & NOW \\
\hline $0: 5$ & 0.00 & 0.0 & 3: & 7.54 \\
\hline $0: 10$ & & 0.02 & $3: 50$ & 7.76 \\
\hline $0: 15$ & 0.01 & 0.07 & $3: 55$ & 7.96 \\
\hline $0: 20$ & 0.03 & 0.15 & $4: 0$ & 8.15 \\
\hline $0: 25$ & 0.05 & 0.25 & 4:5 5 & 8.17 \\
\hline $0: 30$ & 0.08 & 0.34 & $4: 10$ & 8.03 \\
\hline $0: 35$ & 0.11 & 0.50 & $4: 15$ & 7.78 \\
\hline $0: 40$ & 0.16 & 0.73 & $4: 20$ & 7.45 \\
\hline $0: 45$ & 0.25 & 1.10 & $4: 25$ & 7.06 \\
\hline $0: 50$ & 0.42 & 1.84 & $4: 30$ & 6.63 \\
\hline $0: 55$ & 0.71 & 3.07 & $4: 35$ & 6.19 \\
\hline $1: 0$ & 1.07 & 4.51 & $4: 40$ & 5.86 \\
\hline $1: 5$ & 1.42 & 5.74 & $4: 45$ & 5.62 \\
\hline $1: 10$ & 1.74 & 6.68 & $4: 50$ & 5.35 \\
\hline $1: 15$ & 2.11 & 7.68 & $4: 55$ & 5.17 \\
\hline $1: 20$ & 2.52 & 8.64 & $5: 0$ & 5.18 \\
\hline $1: 25$ & 2.86 & 9.11 & $5: 5$ & 5.36 \\
\hline $1: 30$ & 3.10 & 9.16 & $5: 10$ & 5.71 \\
\hline $1: 35$ & 3.26 & 8.91 & $5: 15$ & 6.06 \\
\hline $1: 40$ & 3.44 & 8.82 & $5: 20$ & 6.26 \\
\hline $1: 45$ & 3.63 & 8.84 & $5: 25$ & 6.35 \\
\hline $1: 50$ & 3.84 & 8.99 & $5: 30$ & 6.48 \\
\hline $1: 55$ & 4.05 & 9.23 & $5: 35$ & 6.63 \\
\hline $2: 0$ & 4.15 & 9.20 & $5: 40$ & 6.65 \\
\hline $2: 5$ & 4.16 & 8.98 & $5: 45$ & 6.70 \\
\hline $2: 10$ & 4.12 & 8.64 & $5: 50$ & 6.76 \\
\hline $2: 15$ & 4.24 & 8.90 & $5: 55$ & 6.82 \\
\hline $2: 20$ & 4.77 & 10.52 & $6: 0$ & 6.90 \\
\hline $2: 25$ & 5.57 & 13.00 & $6: 5$ & 7.77 \\
\hline $2: 30$ & 6.65 & 16.34 & $6: 10$ & 8.48 \\
\hline $2: 35$ & 8.00 & 20.45 & $6: 15$ & 9.83 \\
\hline $2: 40$ & 9.15 & 23.65 & $6: 20$ & 12.50 \\
\hline $2: 45$ & 9.91 & 25.05 & $6: 25$ & 15.76 \\
\hline $2: 50$ & 10.48 & 25.50 & $6: 30$ & 18.67 \\
\hline $2: 55$ & 10.82 & 25.08 & $6: 35$ & 21.12 \\
\hline $3: 0$ & 10.75 & 23.42 & $6: 40$ & 23.07 \\
\hline $3: 5$ & 10.35 & 21.13 & $6: 45$ & 24.11 \\
\hline $3: 10$ & 9.77 & 18.72 & $6: 50$ & 24.30 \\
\hline $3: 15$ & 9.08 & 16.49 & $6: 55$ & 23.89 \\
\hline $3: 20$ & 8.50 & 14.85 & $7: 0$ & 23.15 \\
\hline $3: 25$ & 8.17 & 14.08 & $7: 5$ & 22.34 \\
\hline $3: 30$ & 7.89 & 13.56 & $7: 10$ & 21.27 \\
\hline $3: 35$ & 7.67 & 13.27 & $7: 15$ & 20.36 \\
\hline $3: 40$ & 7.49 & 13.16 & $7: 20$ & 19.61 \\
\hline
\end{tabular}


APPROXIMATE 5-YR FLOOD CH13

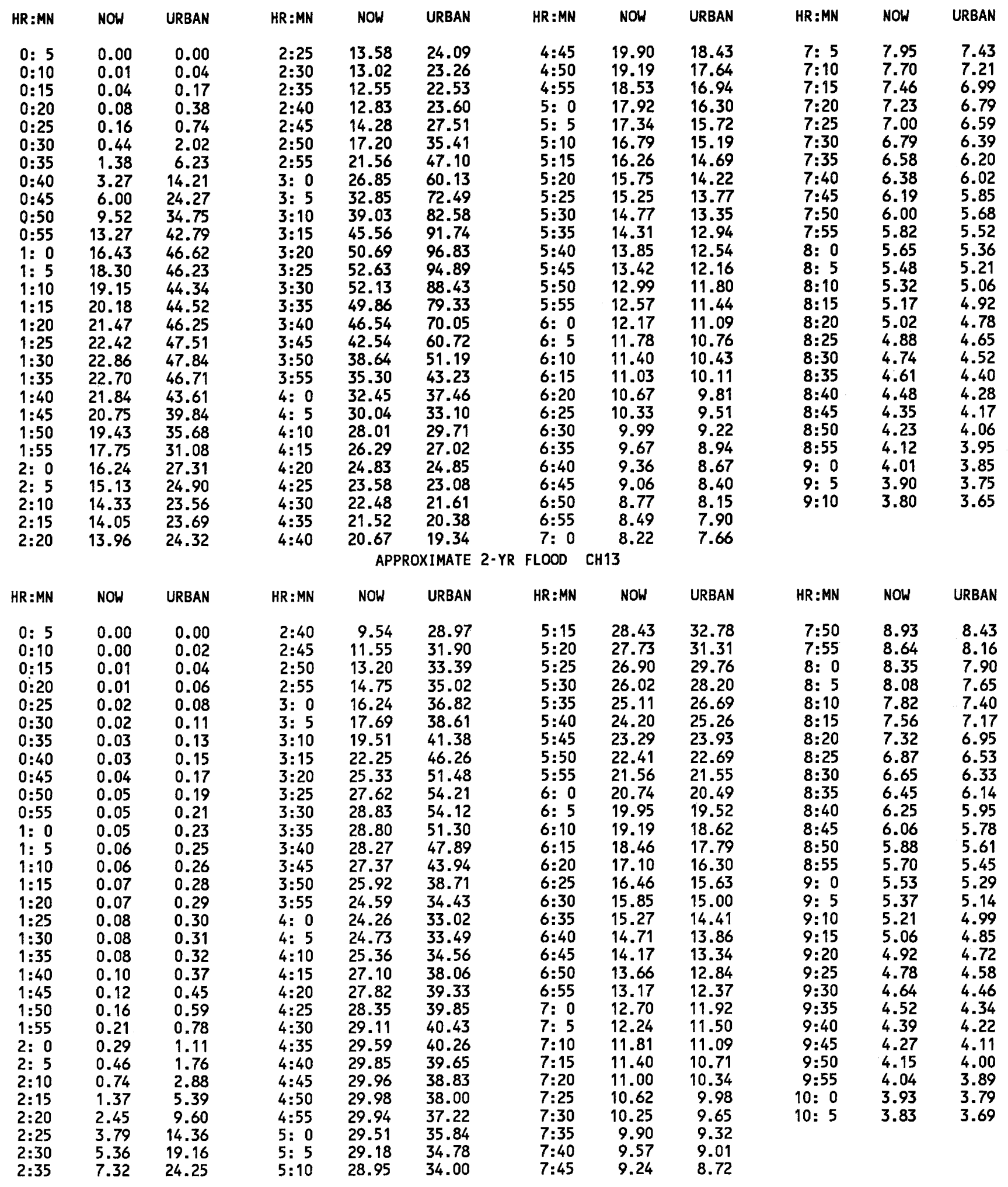



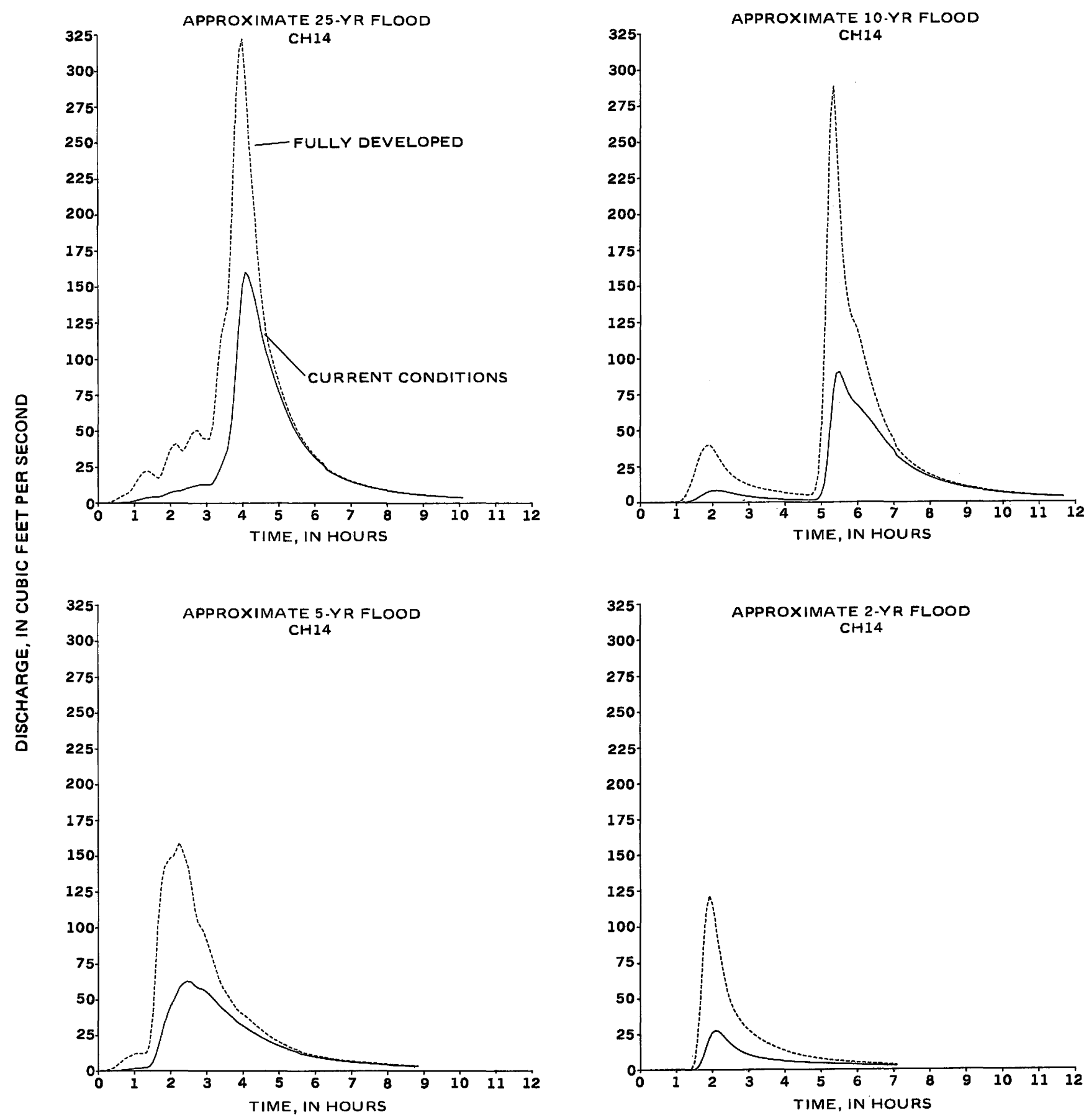

Figure 26. Comparison of approximate 2-, 5-, 10-, and 25-year hydrographs for subbasin CH14 in the Pheasant Branch drainage basin. 
APPROXIMATE 25-YR FLOOD CH14

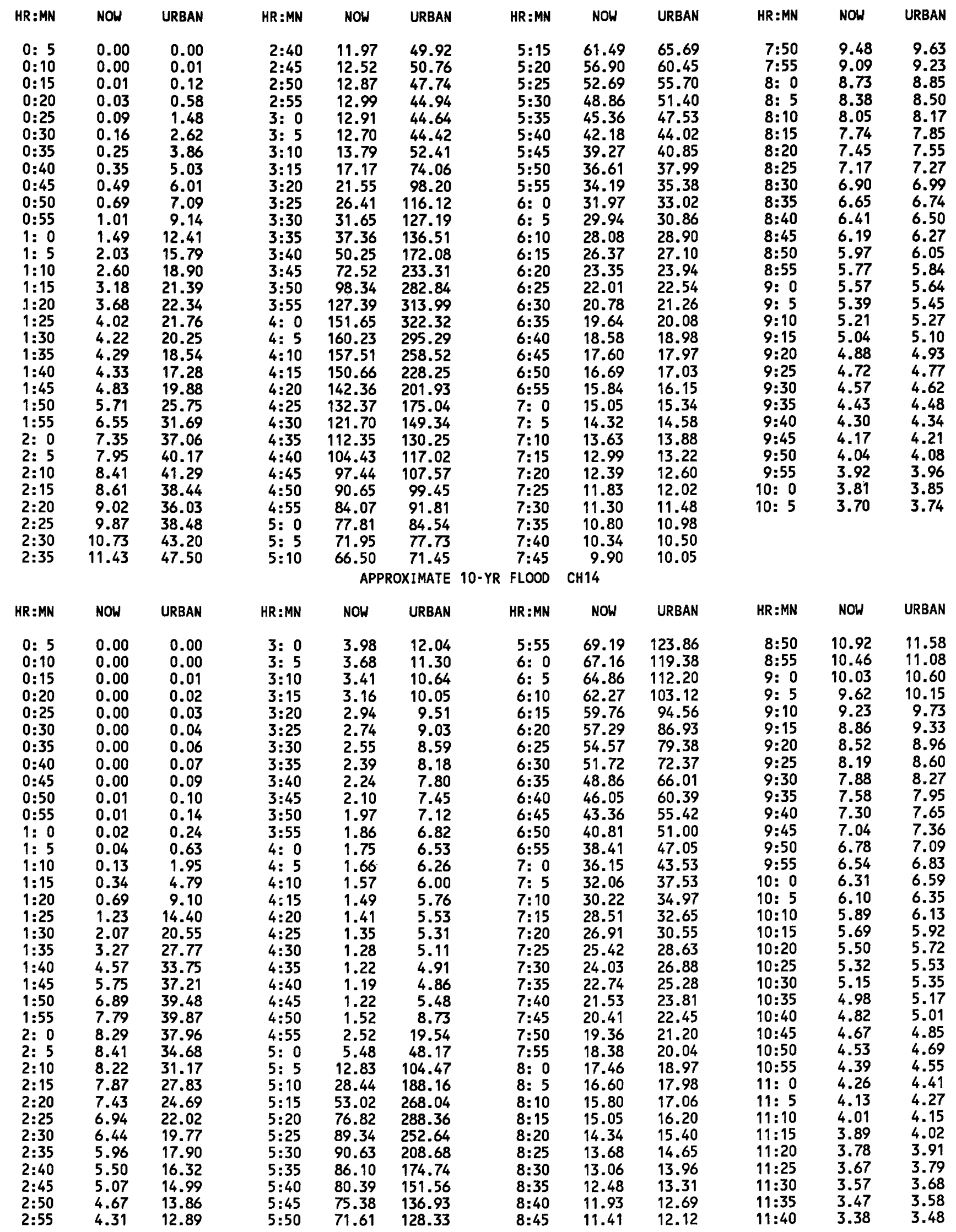


APPROXIMATE 5-YR FLOOD CH14

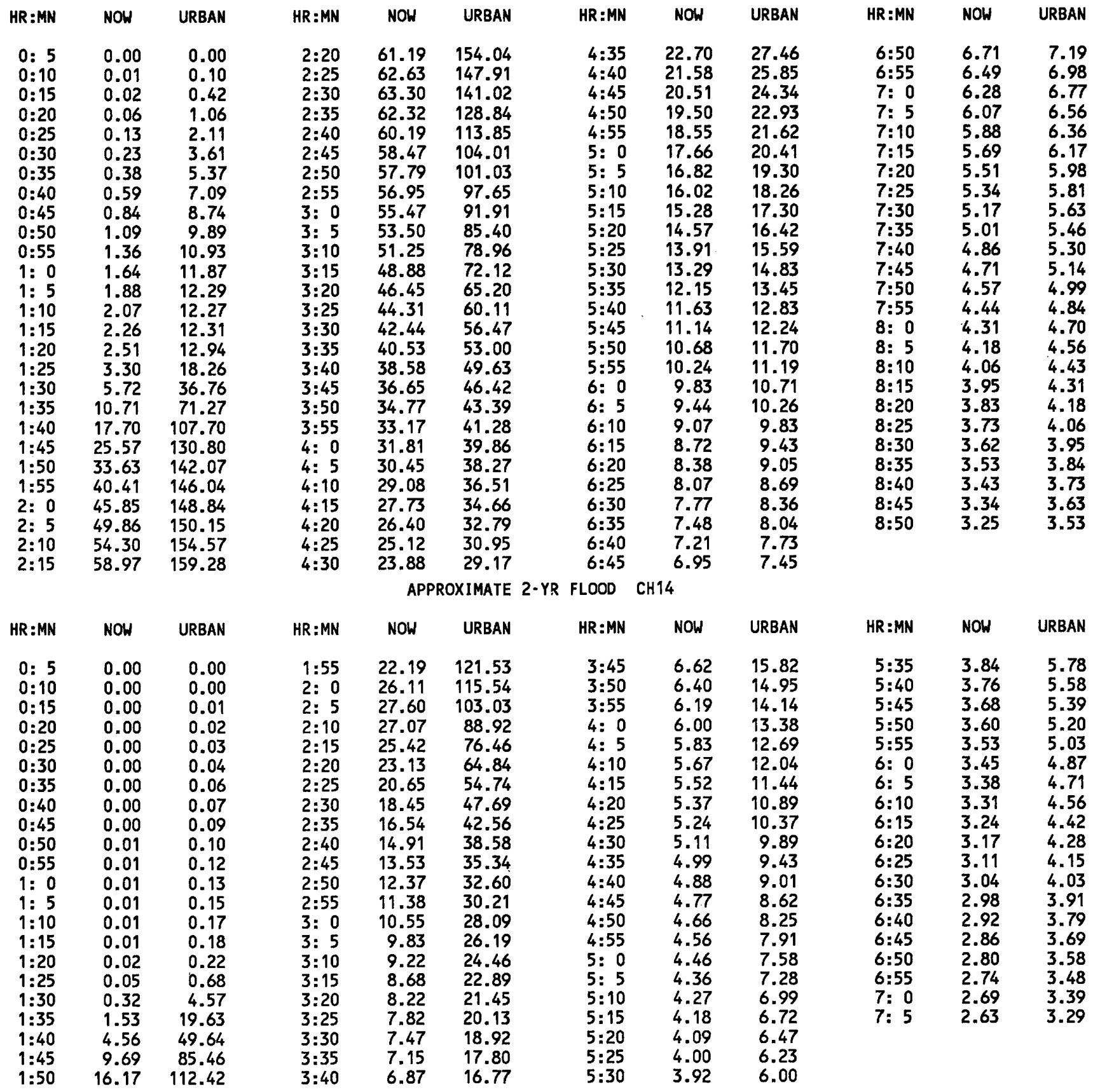



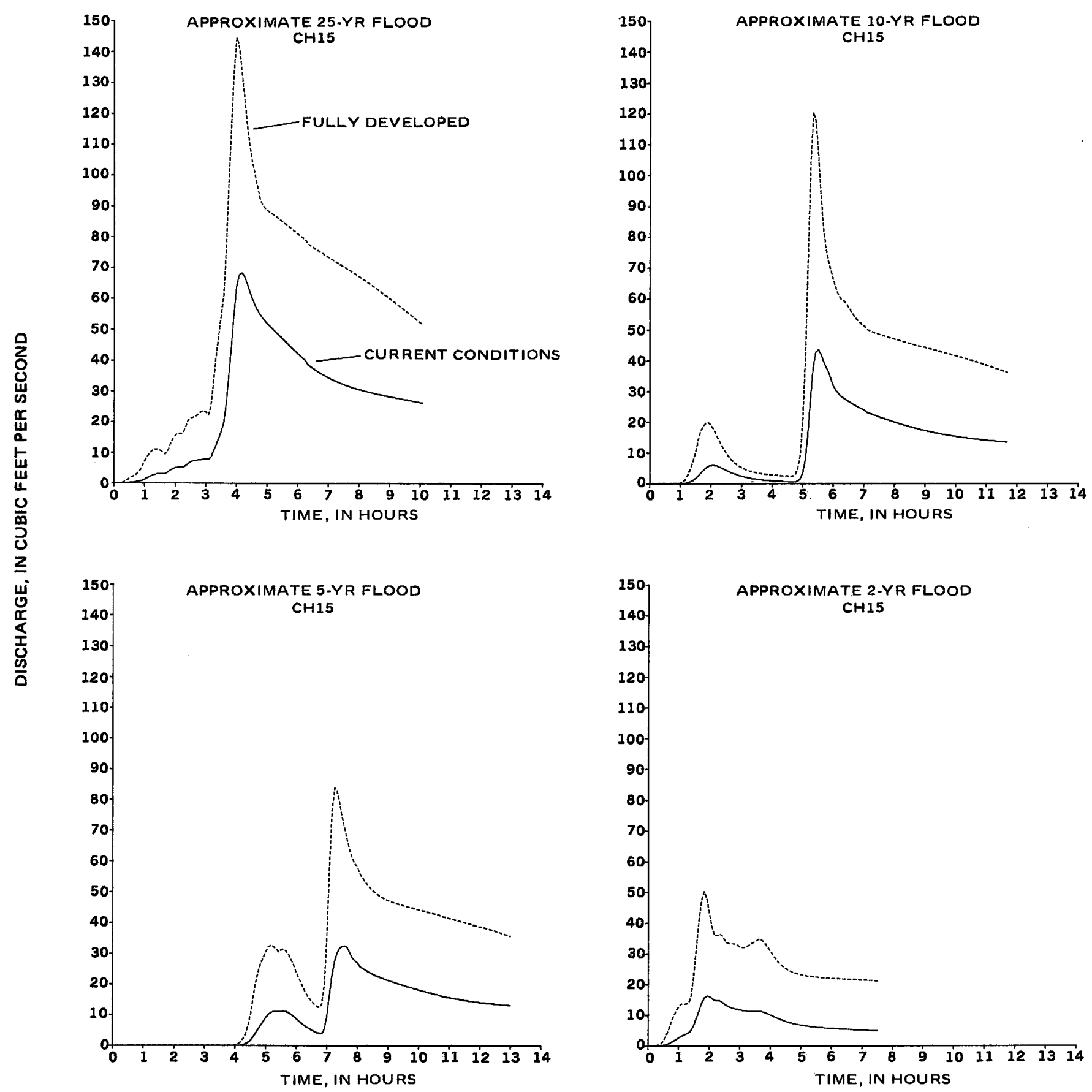

Figure 27. Comparison of approximate 2-, 5-, 10-, and 25-year hydrographs for subbasin $\mathrm{CH} 15$ in the Pheasant Branch drainage basin. 
APPROXIMATE 25-YR FLOOD CH15

\begin{tabular}{|c|c|c|c|c|c|c|c|c|c|c|c|}
\hline HR:MN & NOW & URBAN & HR:MN & NOW & URBAN & HR:MN & NOW & URBAN & HR:MN & NOW & URBAN \\
\hline $\begin{array}{l}0: 5 \\
0: 10 \\
0: 15 \\
0: 20 \\
0: 25 \\
0: 30 \\
0: 35 \\
0: 40 \\
0: 45 \\
0: 50 \\
0: 55 \\
1: 0 \\
1: 5 \\
1: 10 \\
1: 15 \\
1: 20 \\
1: 25 \\
1: 30 \\
1: 35 \\
1: 40 \\
1: 45 \\
1: 50 \\
1: 55 \\
2: 0 \\
2: 5 \\
2: 10 \\
2: 15 \\
2: 20 \\
2: 25 \\
2: 30 \\
2: 35\end{array}$ & $\begin{array}{l}0.00 \\
0.00 \\
0.02 \\
0.08 \\
0.16 \\
0.24 \\
0.32 \\
0.40 \\
0.51 \\
0.67 \\
0.94 \\
1.34 \\
1.77 \\
2.20 \\
2.60 \\
2.89 \\
3.08 \\
3.17 \\
3.19 \\
3.21 \\
3.61 \\
4.26 \\
4.75 \\
5.11 \\
5.28 \\
5.29 \\
5.28 \\
5.67 \\
6.36 \\
6.94 \\
7.28\end{array}$ & $\begin{array}{r}0.00 \\
0.02 \\
0.16 \\
0.54 \\
1.08 \\
1.62 \\
2.13 \\
2.57 \\
3.15 \\
4.06 \\
5.51 \\
7.34 \\
8.78 \\
9.91 \\
10.79 \\
11.14 \\
11.09 \\
10.73 \\
10.17 \\
9.49 \\
10.50 \\
12.73 \\
14.41 \\
15.64 \\
16.15 \\
16.18 \\
16.29 \\
18.10 \\
20.41 \\
21.30 \\
21.54\end{array}$ & $\begin{array}{l}2: 40 \\
2: 45 \\
2: 50 \\
2: 55 \\
3: 0 \\
3: 5 \\
3: 10 \\
3: 15 \\
3: 20 \\
3: 25 \\
3: 30 \\
3: 35 \\
3: 40 \\
3: 45 \\
3: 50 \\
3: 55 \\
4: 0 \\
4: 5 \\
4: 10 \\
4: 15 \\
4: 20 \\
4: 25 \\
4: 30 \\
4: 35 \\
4: 40 \\
4: 45 \\
4: 50 \\
4: 55 \\
5: 0 \\
5: 5 \\
5: 10\end{array}$ & $\begin{array}{r}7.44 \\
7.57 \\
7.70 \\
7.85 \\
7.88 \\
7.80 \\
8.49 \\
10.41 \\
12.51 \\
14.57 \\
16.79 \\
19.47 \\
25.90 \\
35.61 \\
44.99 \\
55.20 \\
63.88 \\
67.65 \\
68.32 \\
67.28 \\
65.13 \\
62.66 \\
60.31 \\
58.18 \\
56.40 \\
55.00 \\
53.82 \\
52.79 \\
51.88 \\
51.03 \\
50.23\end{array}$ & $\begin{array}{r}21.84 \\
22.52 \\
23.24 \\
23.67 \\
23.20 \\
22.23 \\
24.97 \\
33.00 \\
41.16 \\
48.07 \\
54.47 \\
61.06 \\
76.60 \\
98.36 \\
116.44 \\
133.97 \\
144.50 \\
141.81 \\
134.05 \\
125.71 \\
117.48 \\
110.51 \\
105.03 \\
101.07 \\
96.91 \\
92.91 \\
90.68 \\
89.44 \\
88.66 \\
88.05 \\
87.45\end{array}$ & $\begin{array}{l}5: 15 \\
5: 20 \\
5: 25 \\
5: 30 \\
5: 35 \\
5: 40 \\
5: 45 \\
5: 50 \\
5: 55 \\
6: 0 \\
6: 5 \\
6: 10 \\
6: 15 \\
6: 20 \\
6: 25 \\
6: 30 \\
6: 35 \\
6: 40 \\
6: 45 \\
6: 50 \\
6: 55 \\
7: 0 \\
7: 5 \\
7: 10 \\
7: 15 \\
7: 20 \\
7: 25 \\
7: 30 \\
7: 35 \\
7: 40 \\
7: 45\end{array}$ & $\begin{array}{l}49.43 \\
48.64 \\
47.84 \\
47.04 \\
46.22 \\
45.40 \\
44.58 \\
43.77 \\
42.97 \\
42.19 \\
41.42 \\
40.68 \\
39.97 \\
38.62 \\
37.99 \\
37.39 \\
36.82 \\
36.28 \\
35.76 \\
35.27 \\
34.81 \\
34.37 \\
33.95 \\
33.56 \\
33.18 \\
32.83 \\
32.49 \\
32.17 \\
31.86 \\
31.57 \\
31.30\end{array}$ & $\begin{array}{l}86.85 \\
86.24 \\
85.60 \\
84.96 \\
84.30 \\
83.64 \\
82.97 \\
82.29 \\
81.62 \\
80.96 \\
80.30 \\
79.66 \\
79.02 \\
77.80 \\
77.20 \\
76.63 \\
76.06 \\
75.51 \\
74.96 \\
74.43 \\
73.90 \\
73.38 \\
72.86 \\
72.35 \\
71.83 \\
71.32 \\
70.81 \\
70.29 \\
69.78 \\
69.26 \\
68.73\end{array}$ & $\begin{array}{r}7: 50 \\
7: 55 \\
8: 0 \\
8: 5 \\
8: 10 \\
8: 15 \\
8: 20 \\
8: 25 \\
8: 30 \\
8: 35 \\
8: 40 \\
8: 45 \\
8: 50 \\
8: 55 \\
9: 0 \\
9: 55 \\
9: 10 \\
9: 15 \\
9: 20 \\
9: 25 \\
9: 30 \\
9: 35 \\
9: 40 \\
9: 45 \\
9: 50 \\
9: 55 \\
10: 0 \\
10: 5\end{array}$ & $\begin{array}{l}31.03 \\
30.78 \\
30.54 \\
30.31 \\
30.09 \\
29.87 \\
29.67 \\
29.47 \\
29.27 \\
29.09 \\
28.90 \\
28.73 \\
28.55 \\
28.38 \\
28.22 \\
28.06 \\
27.90 \\
27.74 \\
27.58 \\
27.42 \\
27.27 \\
27.12 \\
26.96 \\
26.81 \\
26.66 \\
26.51 \\
26.36 \\
26.20\end{array}$ & $\begin{array}{l}68.20 \\
67.66 \\
67.11 \\
66.56 \\
66.00 \\
65.43 \\
64.86 \\
64.27 \\
63.68 \\
63.09 \\
62.48 \\
61.87 \\
61.26 \\
60.63 \\
60.01 \\
59.37 \\
58.74 \\
58.10 \\
57.45 \\
56.81 \\
56.16 \\
55.50 \\
54.85 \\
54.20 \\
53.55 \\
52.90 \\
52.25 \\
51.60\end{array}$ \\
\hline
\end{tabular}

\begin{tabular}{|c|c|c|c|c|c|c|c|c|c|c|c|}
\hline HR:MN & NOW & URBAN & HR:MN & NOW & URBAN & $H R: M N$ & NOW & URBAN & HR:MN & NOW & URBAN \\
\hline $\begin{array}{l}0: 5 \\
0: 10 \\
0: 15 \\
0: 20 \\
0: 25 \\
0: 30 \\
0: 35 \\
0: 40 \\
0: 45 \\
0: 50 \\
0: 55 \\
1: 0 \\
1: 5 \\
1: 10 \\
1: 15 \\
1: 20 \\
1: 25 \\
1: 30 \\
1: 35 \\
1: 40 \\
1: 45 \\
1: 50 \\
1: 55 \\
2: 0 \\
2: 5 \\
2: 10 \\
2: 15 \\
2: 20 \\
2: 25 \\
2: 30 \\
2: 35 \\
2: 40 \\
2: 45 \\
2: 50 \\
2: 55\end{array}$ & $\begin{array}{l}0.00 \\
0.00 \\
0.00 \\
0.00 \\
0.01 \\
0.01 \\
0.01 \\
0.01 \\
0.02 \\
0.02 \\
0.02 \\
0.03 \\
0.08 \\
0.21 \\
0.43 \\
0.75 \\
1.16 \\
1.74 \\
2.57 \\
3.48 \\
4.32 \\
5.13 \\
5.72 \\
6.01 \\
6.03 \\
5.86 \\
5.54 \\
5.16 \\
4.76 \\
4.35 \\
3.96 \\
3.59 \\
3.26 \\
2.95 \\
2.68\end{array}$ & $\begin{array}{l}0.00 \\
0.01 \\
0.02 \\
0.04 \\
0.05 \\
0.06 \\
0.07 \\
0.08 \\
0.10 \\
0.11 \\
0.14 \\
0.23 \\
0.54 \\
1.41 \\
2.93 \\
4.92 \\
7.29 \\
10.28 \\
14.05 \\
17.09 \\
18.71 \\
19.70 \\
19.83 \\
19.01 \\
17.67 \\
16.07 \\
14.38 \\
12.76 \\
11.24 \\
9.87 \\
8.73 \\
7.77 \\
6.96 \\
6.28 \\
5.71\end{array}$ & $\begin{array}{l}3: 0 \\
3: 5 \\
3: 10 \\
3: 15 \\
3: 20 \\
3: 25 \\
3: 30 \\
3: 35 \\
3: 40 \\
3: 45 \\
3: 50 \\
3: 55 \\
4: 0 \\
4: 5 \\
4: 10 \\
4: 15 \\
4: 20 \\
4: 25 \\
4: 30 \\
4: 35 \\
4: 40 \\
4: 45 \\
4: 50 \\
4: 55 \\
5: 0 \\
5: 5 \\
5: 10 \\
5: 15 \\
5: 20 \\
5: 25 \\
5: 30 \\
5: 35 \\
5: 40 \\
5: 45 \\
5: 50\end{array}$ & $\begin{array}{l}2.43 \\
2.21 \\
2.01 \\
1.84 \\
1.68 \\
1.54 \\
1.42 \\
1.30 \\
1.20 \\
1.11 \\
1.03 \\
0.96 \\
0.89 \\
0.83 \\
0.78 \\
0.73 \\
0.68 \\
0.64 \\
0.61 \\
0.57 \\
0.56 \\
0.61 \\
0.86 \\
1.59 \\
3.51 \\
7.77 \\
16.03 \\
27.71 \\
37.67 \\
42.68 \\
43.64 \\
42.23 \\
39.98 \\
38.07 \\
36.44\end{array}$ & $\begin{array}{r}5.23 \\
4.82 \\
4.47 \\
4.18 \\
3.92 \\
3.70 \\
3.51 \\
3.35 \\
3.21 \\
3.08 \\
2.97 \\
2.88 \\
2.80 \\
2.72 \\
2.66 \\
2.60 \\
2.55 \\
2.50 \\
2.46 \\
2.42 \\
2.48 \\
2.89 \\
4.53 \\
9.25 \\
20.81 \\
42.41 \\
73.80 \\
105.37 \\
120.37 \\
117.12 \\
105.70 \\
92.98 \\
82.44 \\
75.90 \\
71.97\end{array}$ & $\begin{array}{l}5: 55 \\
6: 0 \\
6: 5 \\
6: 10 \\
6: 15 \\
6: 20 \\
6: 25 \\
6: 30 \\
6: 35 \\
6: 40 \\
6: 45 \\
6: 50 \\
6: 55 \\
7: 0 \\
7: 55 \\
7: 10 \\
7: 15 \\
7: 20 \\
7: 25 \\
7: 30 \\
7: 35 \\
7: 40 \\
7: 45 \\
7: 50 \\
7: 55 \\
8: 0 \\
8: 55 \\
8: 10 \\
8: 15 \\
8: 20 \\
8: 25 \\
8: 30 \\
8: 35 \\
8: 40 \\
8: 45\end{array}$ & $\begin{array}{l}33.94 \\
31.61 \\
30.31 \\
29.19 \\
28.37 \\
27.80 \\
27.23 \\
26.68 \\
26.15 \\
25.66 \\
25.19 \\
24.75 \\
24.34 \\
23.95 \\
23.25 \\
22.92 \\
22.60 \\
22.29 \\
21.99 \\
21.69 \\
21.40 \\
21.10 \\
20.82 \\
20.54 \\
20.26 \\
19.98 \\
19.71 \\
19.45 \\
19.19 \\
18.94 \\
18.69 \\
18.45 \\
18.22 \\
17.99 \\
17.77\end{array}$ & $\begin{array}{l}68.83 \\
65.85 \\
63.08 \\
60.93 \\
59.79 \\
59.23 \\
58.31 \\
57.04 \\
55.64 \\
54.40 \\
53.35 \\
52.47 \\
51.74 \\
51.13 \\
50.15 \\
49.74 \\
49.38 \\
49.05 \\
48.74 \\
48.45 \\
48.18 \\
47.91 \\
47.65 \\
47.40 \\
47.16 \\
46.92 \\
46.68 \\
46.44 \\
46.21 \\
45.98 \\
45.75 \\
45.53 \\
45.30 \\
45.08 \\
44.86\end{array}$ & $\begin{array}{c}8: 50 \\
8: 55 \\
9: 0 \\
9: 5 \\
9: 10 \\
9: 15 \\
9: 20 \\
9: 25 \\
9: 30 \\
9: 35 \\
9: 40 \\
9: 45 \\
9: 50 \\
9: 55 \\
10: 0 \\
10: 5 \\
10: 10 \\
10: 15 \\
10: 20 \\
10: 25 \\
10: 30 \\
10: 35 \\
10: 40 \\
10: 45 \\
10: 50 \\
10: 55 \\
11: 0 \\
11: 5 \\
11: 10 \\
11: 15 \\
11: 20 \\
11: 25 \\
11: 30 \\
11: 35 \\
11: 40\end{array}$ & $\begin{array}{l}17.56 \\
17.35 \\
17.15 \\
16.96 \\
16.78 \\
16.60 \\
16.43 \\
16.26 \\
16.10 \\
15.95 \\
15.80 \\
15.66 \\
15.52 \\
15.39 \\
15.27 \\
15.14 \\
15.03 \\
14.91 \\
14.81 \\
14.70 \\
14.60 \\
14.50 \\
14.41 \\
14.32 \\
14.23 \\
14.14 \\
14.06 \\
13.98 \\
13.90 \\
13.82 \\
13.75 \\
13.68 \\
13.61 \\
13.54 \\
13.48\end{array}$ & $\begin{array}{l}44.64 \\
44.42 \\
44.20 \\
43.98 \\
43.76 \\
43.54 \\
43.32 \\
43.10 \\
42.88 \\
42.66 \\
42.43 \\
42.20 \\
41.97 \\
41.74 \\
41.51 \\
41.27 \\
41.03 \\
40.79 \\
40.54 \\
40.29 \\
40.04 \\
39.78 \\
39.52 \\
39.25 \\
38.99 \\
38.72 \\
38.44 \\
38.16 \\
37.88 \\
37.60 \\
37.31 \\
37.02 \\
36.73 \\
36.43 \\
36.14\end{array}$ \\
\hline
\end{tabular}


APPROXIMATE 5-YR FLOOD CH15

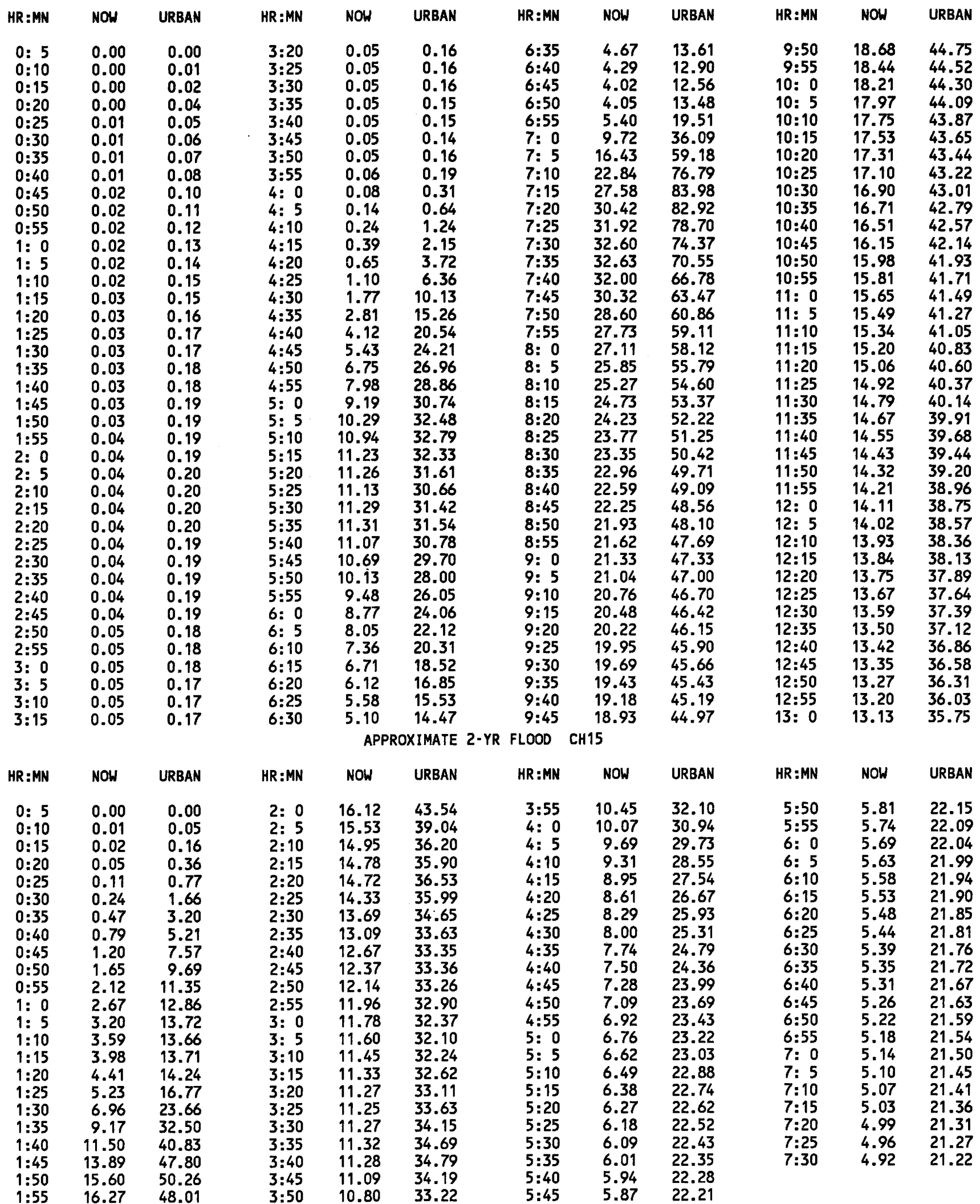



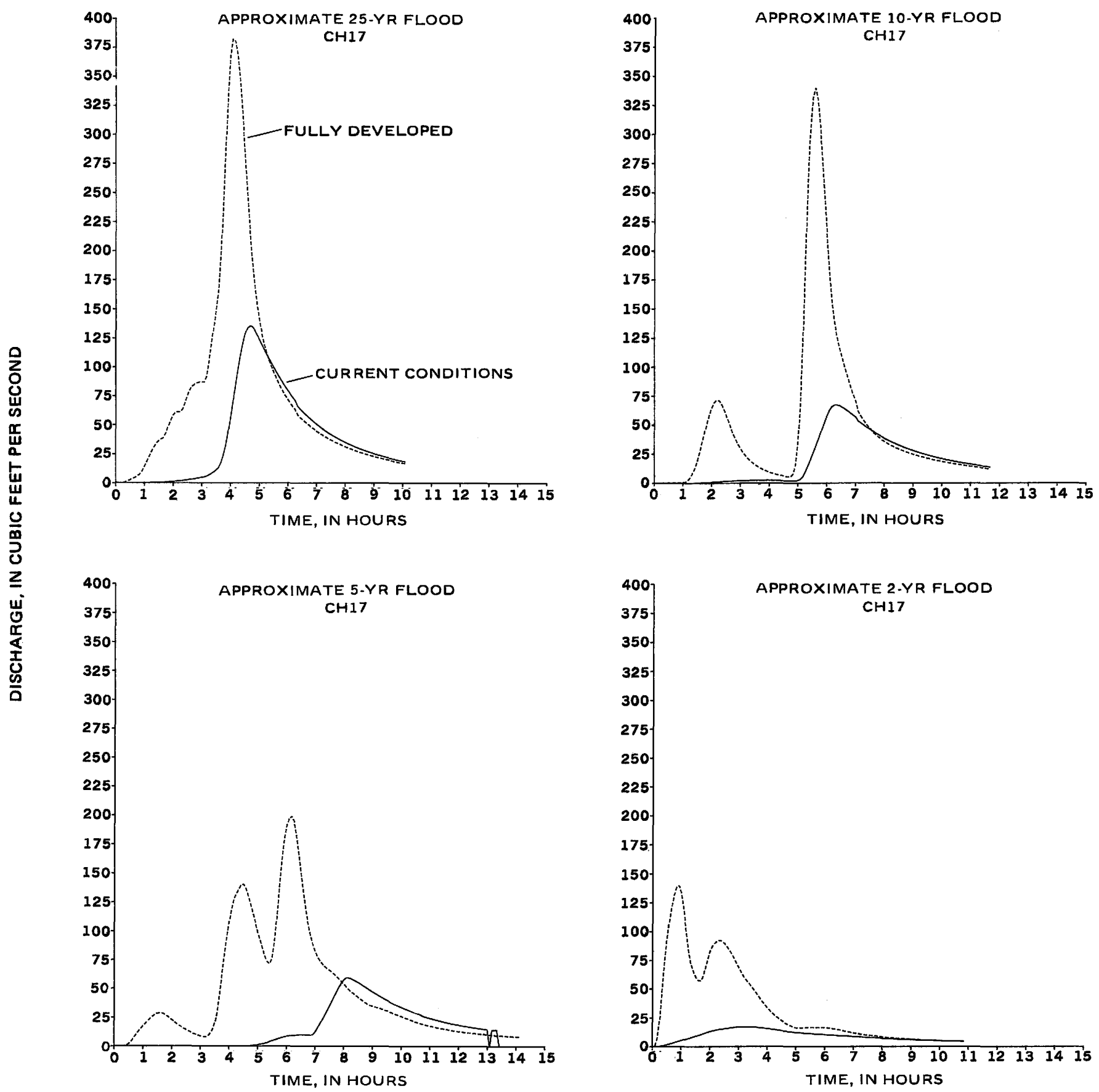

Figure 28. Comparison of approximate 2-, 5-, 10-, and 25-year hydrographs for subbasin CH17 in the Pheasant Branch drainage basin. 
APPROXIMATE 25-YR FLOOD CH17

\begin{tabular}{|c|c|c|c|c|c|c|c|c|c|c|c|}
\hline HR:MN & NOW & URBAN & HR:MN & NOW & URBAN & $H R: M N$ & NOW & URBAN & HR:MN & NOW & URBAN \\
\hline $\begin{array}{l}0: 5 \\
0: 10 \\
0: 15 \\
0: 20 \\
0: 25 \\
0: 30 \\
0: 35 \\
0: 40 \\
0: 45 \\
0: 50 \\
0: 55 \\
1: 0 \\
1: 5 \\
1: 10 \\
1: 15 \\
1: 20 \\
1: 25 \\
1: 30 \\
1: 35 \\
1: 40 \\
1: 45 \\
1: 50 \\
1: 55 \\
2: 0 \\
2: 5 \\
2: 10 \\
2: 15 \\
2: 20 \\
2: 25 \\
2: 30 \\
2: 35\end{array}$ & $\begin{array}{l}0.00 \\
0.00 \\
0.00 \\
0.00 \\
0.01 \\
0.02 \\
0.02 \\
0.03 \\
0.04 \\
0.06 \\
0.08 \\
0.12 \\
0.16 \\
0.21 \\
0.27 \\
0.33 \\
0.39 \\
0.45 \\
0.51 \\
0.58 \\
0.70 \\
0.86 \\
1.03 \\
1.22 \\
1.40 \\
1.59 \\
1.78 \\
2.03 \\
2.36 \\
2.72 \\
3.08\end{array}$ & $\begin{array}{l}0.00 \\
0.04 \\
0.23 \\
0.81 \\
1.70 \\
2.69 \\
3.70 \\
4.68 \\
5.85 \\
7.53 \\
10.22 \\
14.13 \\
18.37 \\
22.79 \\
27.25 \\
31.05 \\
34.13 \\
36.41 \\
37.87 \\
39.00 \\
42.97 \\
49.07 \\
54.48 \\
58.73 \\
60.79 \\
61.21 \\
61.14 \\
63.92 \\
69.63 \\
75.79 \\
80.74\end{array}$ & $\begin{array}{l}2: 40 \\
2: 45 \\
2: 50 \\
2: 55 \\
3: 0 \\
3: 5 \\
3: 10 \\
3: 15 \\
3: 20 \\
3: 25 \\
3: 30 \\
3: 35 \\
3: 40 \\
3: 45 \\
3: 50 \\
3: 55 \\
4: 0 \\
4: 5 \\
4: 10 \\
4: 15 \\
4: 20 \\
4: 25 \\
4: 30 \\
4: 35 \\
4: 40 \\
4: 45 \\
4: 50 \\
4: 55 \\
5: 0 \\
5: 5 \\
5: 10\end{array}$ & $\begin{array}{r}3.44 \\
3.82 \\
4.22 \\
4.62 \\
5.02 \\
5.40 \\
6.02 \\
7.05 \\
8.28 \\
9.67 \\
11.28 \\
13.28 \\
17.30 \\
23.90 \\
32.32 \\
43.43 \\
56.58 \\
70.03 \\
83.40 \\
96.45 \\
108.71 \\
119.48 \\
128.03 \\
133.45 \\
135.43 \\
134.68 \\
131.92 \\
128.19 \\
124.07 \\
119.76 \\
115.57\end{array}$ & $\begin{array}{r}83.75 \\
85.49 \\
86.36 \\
87.06 \\
87.17 \\
86.89 \\
91.82 \\
104.77 \\
120.33 \\
135.27 \\
149.67 \\
165.96 \\
196.42 \\
241.23 \\
289.65 \\
335.34 \\
368.81 \\
382.41 \\
380.59 \\
368.39 \\
346.37 \\
316.80 \\
283.31 \\
249.88 \\
219.83 \\
194.07 \\
172.26 \\
154.52 \\
140.60 \\
129.46 \\
120.58\end{array}$ & $\begin{array}{l}5: 15 \\
5: 20 \\
5: 25 \\
5: 30 \\
5: 35 \\
5: 40 \\
5: 45 \\
5: 50 \\
5: 55 \\
6: 0 \\
6: 5 \\
6: 10 \\
6: 15 \\
6: 20 \\
6: 25 \\
6: 30 \\
6: 35 \\
6: 40 \\
6: 45 \\
6: 50 \\
6: 55 \\
7: 0 \\
7: 5 \\
7: 10 \\
7: 15 \\
7: 20 \\
7: 25 \\
7: 30 \\
7: 35 \\
7: 40 \\
7: 45\end{array}$ & $\begin{array}{r}111.45 \\
107.42 \\
103.43 \\
99.66 \\
95.99 \\
92.43 \\
88.92 \\
85.65 \\
82.43 \\
79.44 \\
76.58 \\
73.77 \\
71.17 \\
66.29 \\
64.02 \\
61.84 \\
59.75 \\
57.76 \\
55.85 \\
54.03 \\
52.28 \\
50.60 \\
49.00 \\
47.46 \\
45.98 \\
44.57 \\
43.21 \\
41.90 \\
40.65 \\
39.45 \\
38.29\end{array}$ & $\begin{array}{r}112.89 \\
106.48 \\
100.83 \\
95.54 \\
90.77 \\
86.21 \\
82.02 \\
78.29 \\
74.75 \\
71.59 \\
68.65 \\
65.92 \\
63.37 \\
58.74 \\
56.63 \\
54.64 \\
52.75 \\
50.96 \\
49.26 \\
47.65 \\
46.11 \\
44.65 \\
43.25 \\
41.92 \\
40.64 \\
39.42 \\
38.24 \\
37.12 \\
36.04 \\
35.01 \\
34.02\end{array}$ & $\begin{array}{r}7: 50 \\
7: 55 \\
8: 0 \\
8: 5 \\
8: 10 \\
8: 15 \\
8: 20 \\
8: 25 \\
8: 30 \\
8: 35 \\
8: 40 \\
8: 45 \\
8: 50 \\
8: 55 \\
9: 0 \\
9: 5 \\
9: 10 \\
9: 15 \\
9: 20 \\
9: 25 \\
9: 30 \\
9: 35 \\
9: 40 \\
9: 45 \\
9: 50 \\
9: 55 \\
10: 0 \\
10: 5\end{array}$ & $\begin{array}{l}37.18 \\
36.11 \\
35.08 \\
34.10 \\
33.14 \\
32.22 \\
31.34 \\
30.49 \\
29.67 \\
28.88 \\
28.12 \\
27.38 \\
26.67 \\
25.99 \\
25.32 \\
24.68 \\
24.07 \\
23.47 \\
22.89 \\
22.33 \\
21.79 \\
21.27 \\
20.77 \\
20.28 \\
19.80 \\
19.35 \\
18.90 \\
18.47\end{array}$ & $\begin{array}{l}33.06 \\
32.15 \\
31.26 \\
30.42 \\
29.60 \\
28.81 \\
28.05 \\
27.32 \\
26.61 \\
25.93 \\
25.27 \\
24.64 \\
24.02 \\
23.43 \\
22.86 \\
22.30 \\
21.77 \\
21.25 \\
20.75 \\
20.26 \\
19.79 \\
19.33 \\
18.89 \\
18.47 \\
18.05 \\
17.65 \\
17.26 \\
16.88\end{array}$ \\
\hline
\end{tabular}

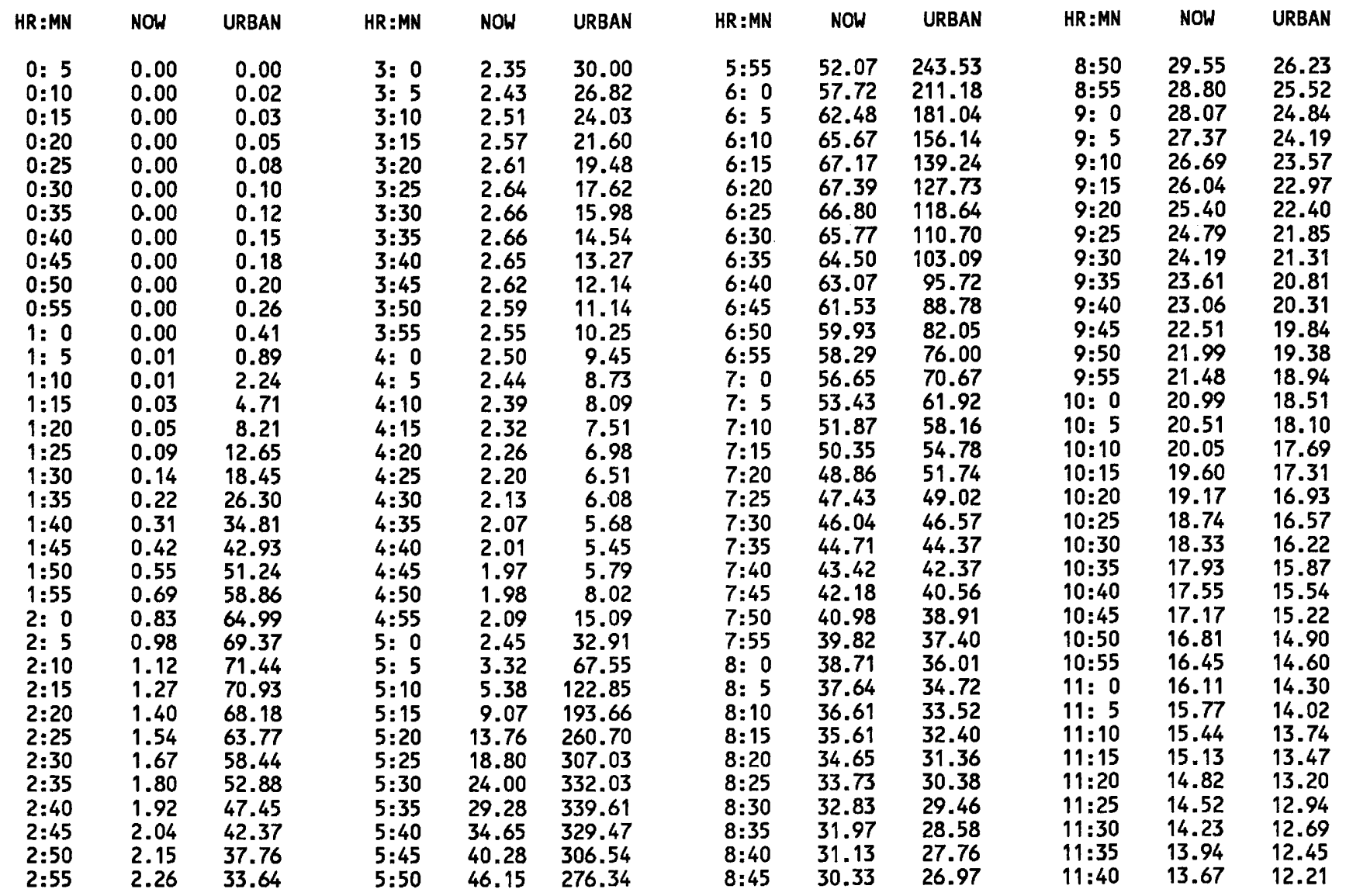


APPROXIMATE 5-YR FLOOD CH17

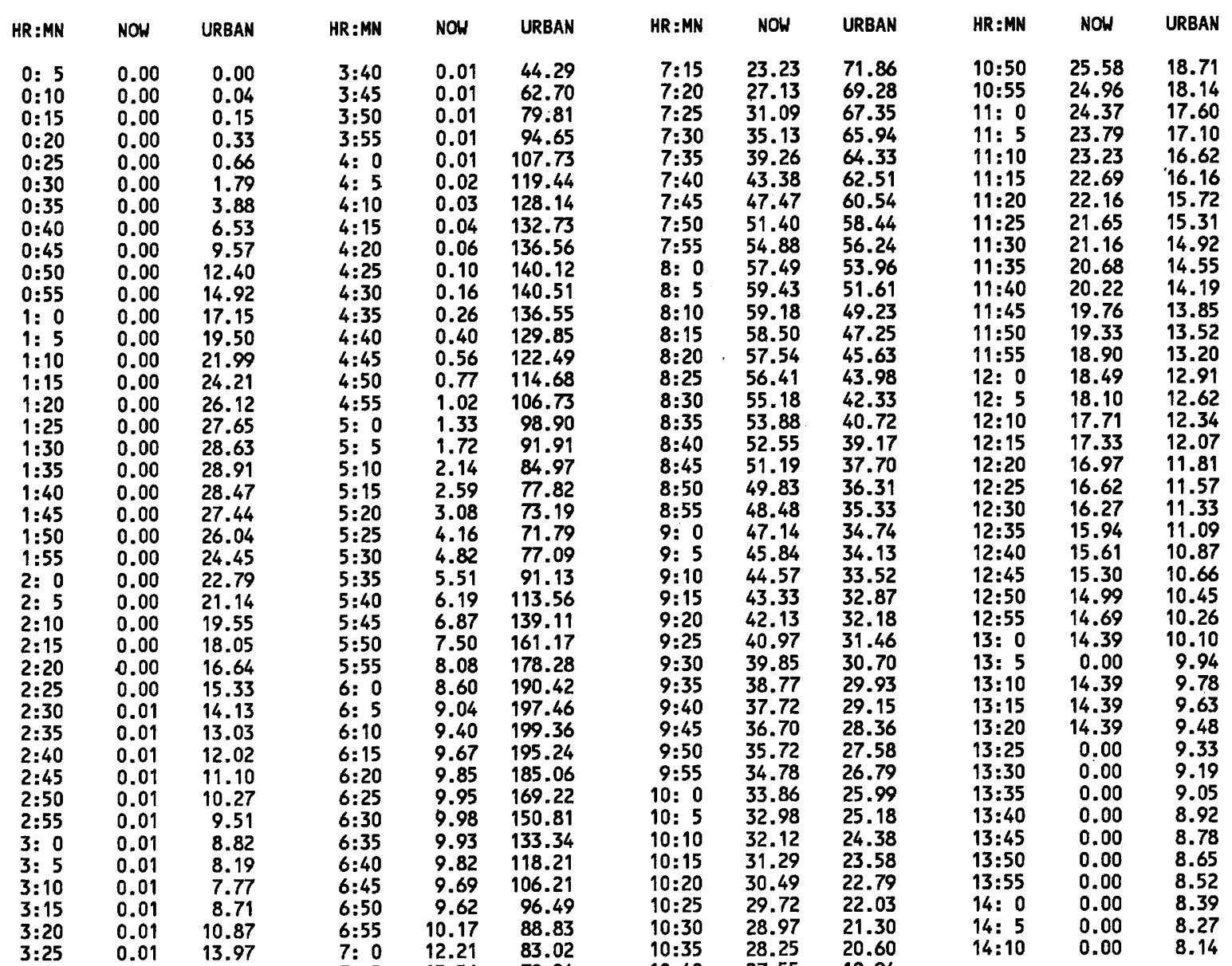

$\begin{array}{lllllllll}3: 30 & 0.01 & 19.72 & 7: 5 & 15.56 & 78.24 & 10: 40 & 27.55 & 19.94 \\ 3: 35 & 0.01 & 29.27 & 7: 10 & 19.34 & 74.55 & 10.45 & 26.21 & 19.31\end{array}$

APPROXIMATE 2-YR FLOOD CH17

\begin{tabular}{|c|c|c|c|c|c|c|c|c|c|c|c|}
\hline$H R: M N$ & NOW & URBAN & $H R: M N$ & NOW & URBAN & HR:MN & NOW & URBAN & HR:MN & NOW & URBAN \\
\hline $\begin{array}{l}0: 5 \\
0: 10 \\
0: 15 \\
0: 20 \\
0: 25 \\
0: 30 \\
0: 35 \\
0: 40 \\
0: 45 \\
0: 50 \\
0: 55 \\
1: 0 \\
1: 5 \\
1: 10 \\
1: 15 \\
1: 20 \\
1: 25 \\
1: 30 \\
1: 35 \\
1: 40 \\
1: 45 \\
1: 50 \\
1: 55 \\
2: 0 \\
2: 5 \\
2: 10 \\
2: 15 \\
2: 20 \\
2: 25 \\
2: 30 \\
2: 35 \\
2: 40\end{array}$ & $\begin{array}{r}0.01 \\
0.09 \\
0.29 \\
0.64 \\
1.11 \\
1.63 \\
2.21 \\
2.81 \\
3.42 \\
4.03 \\
4.65 \\
5.26 \\
5.87 \\
6.47 \\
7.07 \\
7.73 \\
8.41 \\
9.05 \\
9.68 \\
10.29 \\
10.98 \\
11.74 \\
12.49 \\
13.16 \\
13.72 \\
14.19 \\
14.61 \\
14.98 \\
15.30 \\
15.58 \\
15.86 \\
16.21\end{array}$ & $\begin{array}{r}0.78 \\
6.93 \\
23.60 \\
49.38 \\
74.30 \\
93.57 \\
109.63 \\
122.00 \\
131.59 \\
138.23 \\
139.72 \\
133.21 \\
119.11 \\
101.16 \\
83.56 \\
72.26 \\
65.60 \\
60.58 \\
57.57 \\
56.94 \\
60.15 \\
67.11 \\
75.50 \\
82.48 \\
87.21 \\
89.84 \\
91.64 \\
92.48 \\
91.69 \\
89.87 \\
87.35 \\
84.43\end{array}$ & $\begin{array}{l}2: 50 \\
2: 55 \\
3: 0 \\
3: 5 \\
3: 10 \\
3: 15 \\
3: 20 \\
3: 25 \\
3: 30 \\
3: 35 \\
3: 40 \\
3: 45 \\
3: 50 \\
3: 55 \\
4: 0 \\
4: 5 \\
4: 10 \\
4: 15 \\
4: 20 \\
4: 25 \\
4: 30 \\
4: 35 \\
4: 40 \\
4: 45 \\
4: 50 \\
4: 55 \\
5: 0 \\
5: 5 \\
5: 10 \\
5: 15 \\
5: 20 \\
5: 25\end{array}$ & $\begin{array}{l}16.86 \\
17.08 \\
17.22 \\
17.29 \\
17.28 \\
17.25 \\
17.19 \\
17.08 \\
16.93 \\
16.76 \\
16.55 \\
16.32 \\
16.08 \\
15.81 \\
15.53 \\
15.24 \\
14.95 \\
14.65 \\
14.35 \\
14.05 \\
13.75 \\
13.46 \\
13.18 \\
12.90 \\
12.63 \\
12.36 \\
12.12 \\
11.92 \\
11.75 \\
11.58 \\
11.42 \\
11.25\end{array}$ & $\begin{array}{l}77.32 \\
73.07 \\
68.98 \\
65.02 \\
61.23 \\
58.14 \\
55.64 \\
53.10 \\
50.44 \\
47.58 \\
44.59 \\
41.60 \\
38.71 \\
36.01 \\
33.52 \\
31.25 \\
29.18 \\
27.28 \\
25.54 \\
23.94 \\
22.47 \\
21.13 \\
19.90 \\
18.77 \\
17.75 \\
16.82 \\
16.17 \\
16.04 \\
16.20 \\
16.35 \\
16.47 \\
16.57\end{array}$ & $\begin{array}{l}5: 35 \\
5: 40 \\
5: 45 \\
5: 50 \\
5: 55 \\
6: 0 \\
6: 5 \\
6: 10 \\
6: 15 \\
6: 20 \\
6: 25 \\
6: 30 \\
6: 35 \\
6: 40 \\
6: 45 \\
6: 50 \\
6: 55 \\
7: 0 \\
7: 5 \\
7: 10 \\
7: 15 \\
7: 20 \\
7: 25 \\
7: 30 \\
7: 35 \\
7: 40 \\
7: 45 \\
7: 50 \\
7: 55 \\
8: 0 \\
8: 5 \\
8: 10\end{array}$ & $\begin{array}{l}10.94 \\
10.79 \\
10.64 \\
10.49 \\
10.35 \\
10.21 \\
10.07 \\
9.93 \\
9.79 \\
9.65 \\
9.51 \\
9.37 \\
9.23 \\
9.09 \\
8.94 \\
8.81 \\
8.67 \\
8.53 \\
8.40 \\
8.26 \\
8.13 \\
8.01 \\
7.88 \\
7.76 \\
7.64 \\
7.52 \\
7.40 \\
7.29 \\
7.18 \\
7.07 \\
6.96 \\
6.86\end{array}$ & $\begin{array}{r}16.65 \\
16.63 \\
16.59 \\
16.51 \\
16.40 \\
16.26 \\
16.08 \\
15.85 \\
15.56 \\
15.22 \\
14.82 \\
14.39 \\
13.93 \\
13.45 \\
12.98 \\
12.50 \\
12.04 \\
11.62 \\
11.25 \\
10.89 \\
10.55 \\
10.23 \\
9.92 \\
9.64 \\
9.36 \\
9.11 \\
8.86 \\
8.63 \\
8.42 \\
8.21 \\
8.01 \\
7.82\end{array}$ & $\begin{array}{r}8: 20 \\
8: 25 \\
8: 30 \\
8: 35 \\
8: 40 \\
8: 45 \\
8: 50 \\
8: 55 \\
9: 0 \\
9: 55 \\
9: 10 \\
9: 15 \\
9: 20 \\
9: 25 \\
9: 30 \\
9: 35 \\
9: 40 \\
9: 45 \\
9: 50 \\
9: 55 \\
10: 0 \\
10: 55 \\
10: 10 \\
10: 15 \\
10: 20 \\
10: 25 \\
10: 30 \\
10: 35 \\
10: 40 \\
10: 45 \\
10: 50\end{array}$ & $\begin{array}{l}6.66 \\
6.56 \\
6.46 \\
6.37 \\
6.28 \\
6.19 \\
6.10 \\
6.01 \\
5.92 \\
5.84 \\
5.76 \\
5.68 \\
5.60 \\
5.52 \\
5.44 \\
5.37 \\
5.30 \\
5.22 \\
5.15 \\
5.08 \\
5.02 \\
4.95 \\
4.88 \\
4.82 \\
4.76 \\
4.69 \\
4.63 \\
4.57 \\
4.51 \\
4.46 \\
4.40\end{array}$ & $\begin{array}{l}7.47 \\
7.30 \\
7.14 \\
6.98 \\
6.83 \\
6.68 \\
6.54 \\
6.40 \\
6.27 \\
6.14 \\
6.01 \\
5.89 \\
5.78 \\
5.66 \\
5.56 \\
5.45 \\
5.35 \\
5.25 \\
5.16 \\
5.06 \\
4.98 \\
4.89 \\
4.81 \\
4.73 \\
4.65 \\
4.57 \\
4.50 \\
4.43 \\
4.36 \\
4.29 \\
4.23\end{array}$ \\
\hline
\end{tabular}



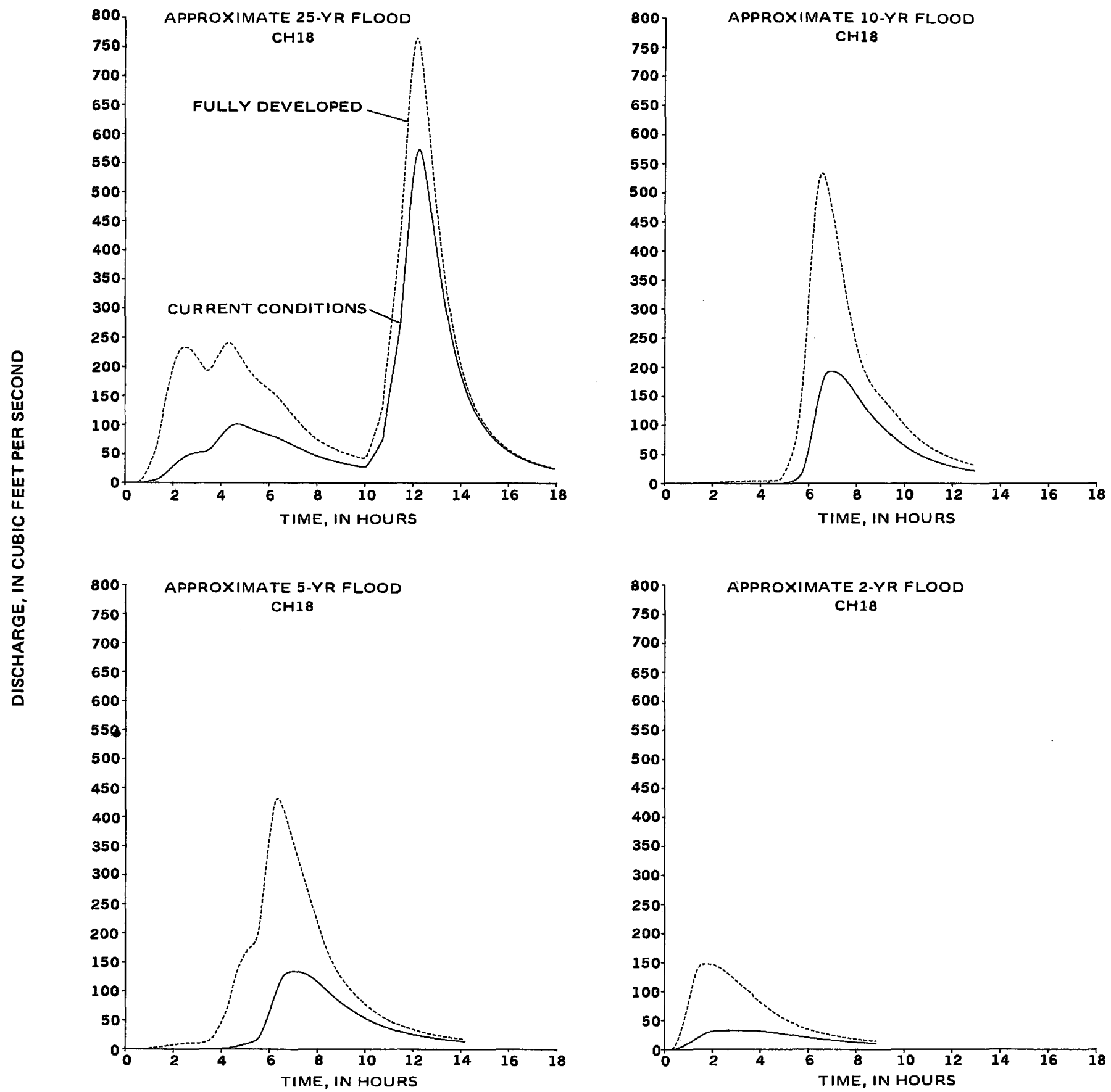

Figure 29. Comparison of approximate 2-, 5-, 10-, and 25-year hydrographs for subbasin CH18 in the Pheasant Branch drainage basin. 


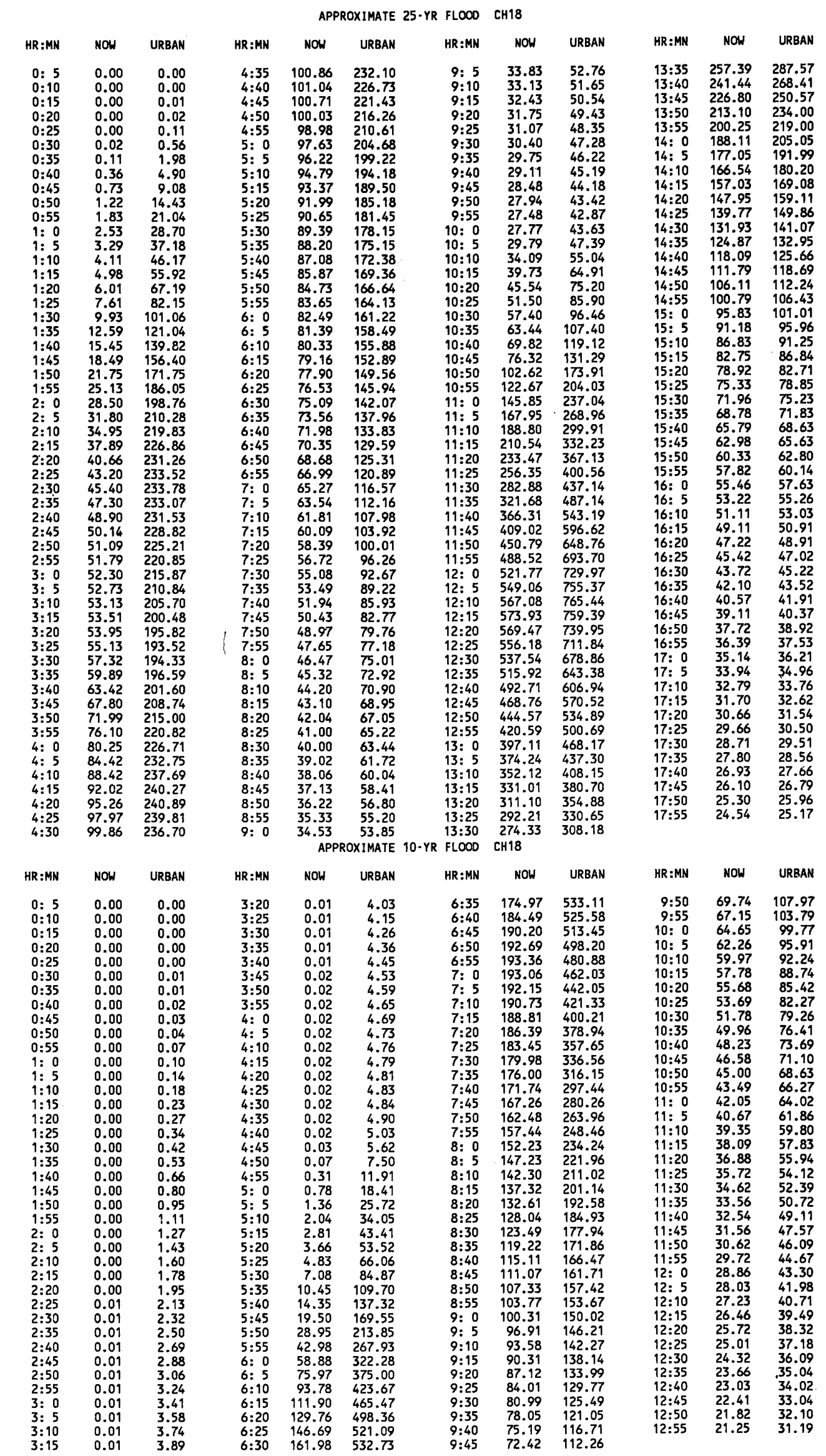


APPROXIMATE 5-YR FLOOD CH18

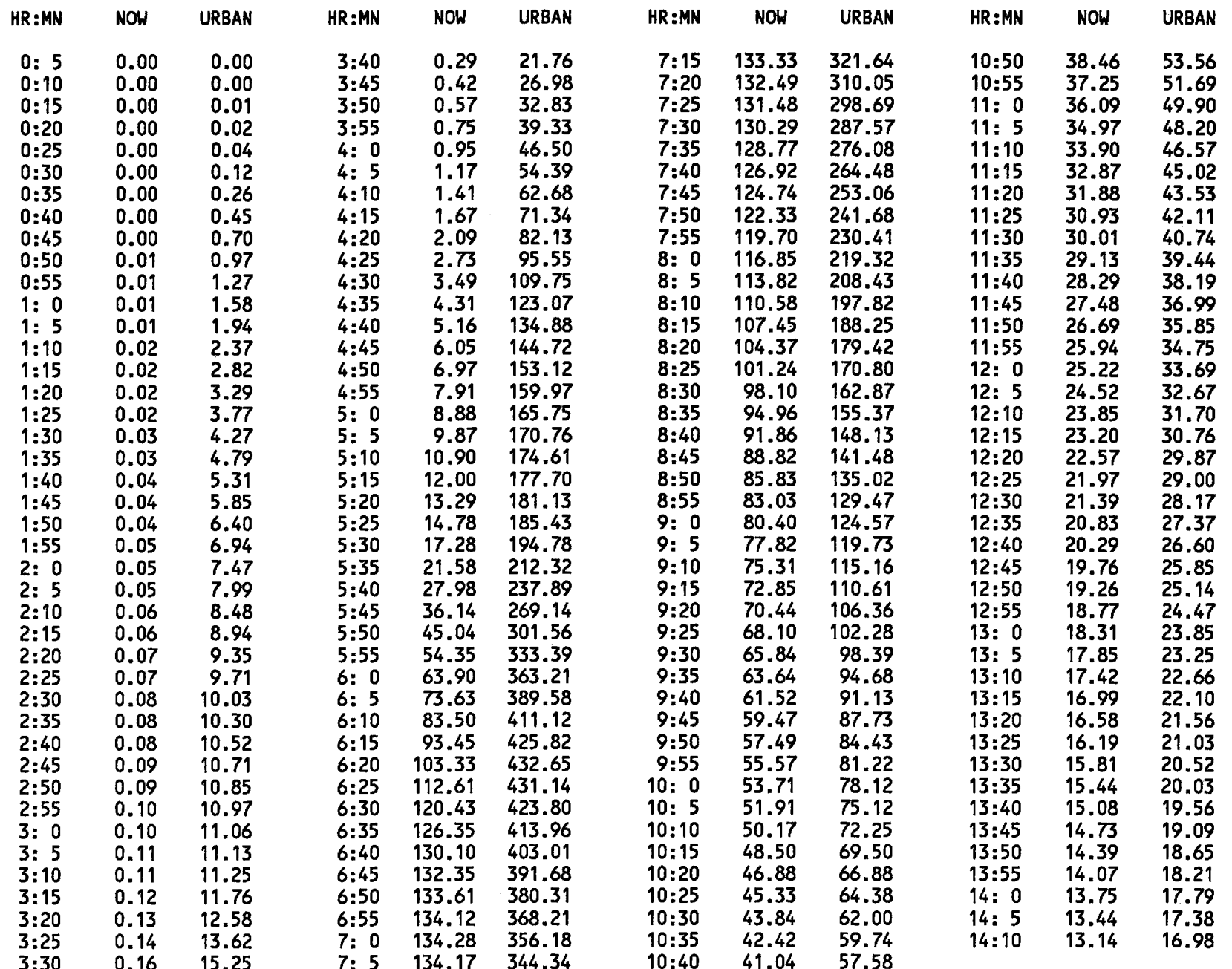

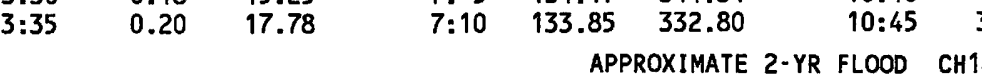

\begin{tabular}{|c|c|c|c|c|c|c|c|c|c|c|c|}
\hline HR:MN & NOW & URBAN & $H R: M N$ & NOW & URBAN & $H R: M N$ & NOW & URBAN & $H R: M N$ & NOW & URBAN \\
\hline $\begin{array}{l}0: 5 \\
0: 10 \\
0: 15 \\
0: 20 \\
0: 25 \\
0: 30 \\
0: 35 \\
0: 40 \\
0: 45 \\
0: 50 \\
0: 55 \\
1: 0 \\
1: 5 \\
1: 10 \\
1: 15 \\
1: 20 \\
1: 25 \\
1: 30 \\
1: 35 \\
1: 40 \\
1: 45 \\
1: 50 \\
1: 55 \\
2: 0 \\
2: 5 \\
2: 10 \\
2: 15\end{array}$ & $\begin{array}{l}0.00 \\
0.00 \\
0.00 \\
0.03 \\
0.35 \\
1.18 \\
2.35 \\
3.70 \\
5.20 \\
6.80 \\
8.51 \\
10.31 \\
12.19 \\
14.14 \\
16.17 \\
18.25 \\
20.38 \\
22.51 \\
24.58 \\
26.49 \\
28.16 \\
29.52 \\
30.58 \\
31.37 \\
31.92 \\
32.30 \\
32.55\end{array}$ & $\begin{array}{r}0.00 \\
0.00 \\
0.10 \\
0.79 \\
3.75 \\
10.16 \\
18.90 \\
29.08 \\
40.25 \\
52.25 \\
64.98 \\
78.37 \\
92.34 \\
106.82 \\
121.16 \\
133.29 \\
141.28 \\
145.38 \\
147.11 \\
147.77 \\
147.87 \\
147.65 \\
147.17 \\
146.45 \\
145.45 \\
144.16 \\
142.54\end{array}$ & $\begin{array}{l}2: 20 \\
2: 25 \\
2: 30 \\
2: 35 \\
2: 40 \\
2: 45 \\
2: 50 \\
2: 55 \\
3: 0 \\
3: 5 \\
3: 10 \\
3: 15 \\
3: 20 \\
3: 25 \\
3: 30 \\
3: 35 \\
3: 40 \\
3: 45 \\
3: 50 \\
3: 55 \\
4: 0 \\
4: 5 \\
4: 10 \\
4: 15 \\
4: 20 \\
4: 25 \\
4: 30\end{array}$ & $\begin{array}{l}32.71 \\
32.80 \\
32.85 \\
32.89 \\
32.93 \\
32.95 \\
32.95 \\
32.93 \\
32.92 \\
32.92 \\
32.89 \\
32.84 \\
32.79 \\
32.74 \\
32.67 \\
32.56 \\
32.43 \\
32.06 \\
31.84 \\
31.58 \\
31.29 \\
30.98 \\
30.64 \\
30.28 \\
29.89 \\
29.48 \\
29.05\end{array}$ & $\begin{array}{l}140.56 \\
138.27 \\
135.66 \\
133.09 \\
130.55 \\
127.74 \\
124.63 \\
121.41 \\
118.35 \\
115.46 \\
112.38 \\
109.32 \\
106.48 \\
103.86 \\
101.14 \\
98.35 \\
95.52 \\
89.85 \\
87.01 \\
84.19 \\
81.40 \\
78.63 \\
75.91 \\
73.23 \\
70.60 \\
68.04 \\
65.57\end{array}$ & $\begin{array}{l}4: 35 \\
4: 40 \\
4: 45 \\
4: 50 \\
4: 55 \\
5: 0 \\
5: 5 \\
5: 10 \\
5: 15 \\
5: 20 \\
5: 25 \\
5: 30 \\
5: 35 \\
5: 40 \\
5: 45 \\
5: 50 \\
5: 55 \\
6: 0 \\
6: 5 \\
6: 10 \\
6: 15 \\
6: 20 \\
6: 25 \\
6: 30 \\
6: 35 \\
6: 40 \\
6: 45\end{array}$ & $\begin{array}{l}28.61 \\
28.15 \\
27.69 \\
27.21 \\
26.73 \\
26.25 \\
25.76 \\
25.27 \\
24.78 \\
24.30 \\
23.81 \\
23.33 \\
22.39 \\
21.93 \\
21.47 \\
21.02 \\
20.58 \\
20.14 \\
19.71 \\
19.29 \\
18.88 \\
18.48 \\
18.08 \\
17.69 \\
17.31 \\
16.94 \\
16.58\end{array}$ & $\begin{array}{l}63.19 \\
60.90 \\
58.71 \\
56.62 \\
54.61 \\
52.70 \\
50.87 \\
49.13 \\
47.46 \\
45.86 \\
44.33 \\
42.88 \\
40.14 \\
38.86 \\
37.64 \\
36.46 \\
35.33 \\
34.25 \\
33.22 \\
32.22 \\
31.27 \\
30.35 \\
29.47 \\
28.62 \\
27.81 \\
27.02 \\
26.27\end{array}$ & $\begin{array}{l}6: 50 \\
6: 55 \\
7: 0 \\
7: 5 \\
7: 10 \\
7: 15 \\
7: 20 \\
7: 25 \\
7: 30 \\
7: 35 \\
7: 40 \\
7: 45 \\
7: 50 \\
7: 55 \\
8: 0 \\
8: 5 \\
8: 10 \\
8: 15 \\
8: 20 \\
8: 25 \\
8: 30 \\
8: 35 \\
8: 40 \\
8: 45 \\
8: 50\end{array}$ & $\begin{array}{r}16.23 \\
15.88 \\
15.54 \\
15.21 \\
14.89 \\
14.58 \\
14.27 \\
13.68 \\
13.39 \\
13.11 \\
12.84 \\
12.58 \\
12.32 \\
12.07 \\
11.83 \\
11.59 \\
11.35 \\
11.13 \\
10.91 \\
10.69 \\
10.48 \\
10.27 \\
10.07 \\
9.88 \\
9.69\end{array}$ & $\begin{array}{l}25.54 \\
24.84 \\
24.17 \\
23.52 \\
22.89 \\
22.29 \\
21.71 \\
20.60 \\
20.08 \\
19.57 \\
19.08 \\
18.61 \\
18.15 \\
17.71 \\
17.28 \\
16.86 \\
16.46 \\
16.08 \\
15.70 \\
15.33 \\
14.98 \\
14.64 \\
14.31 \\
13.99 \\
13.69\end{array}$ \\
\hline
\end{tabular}



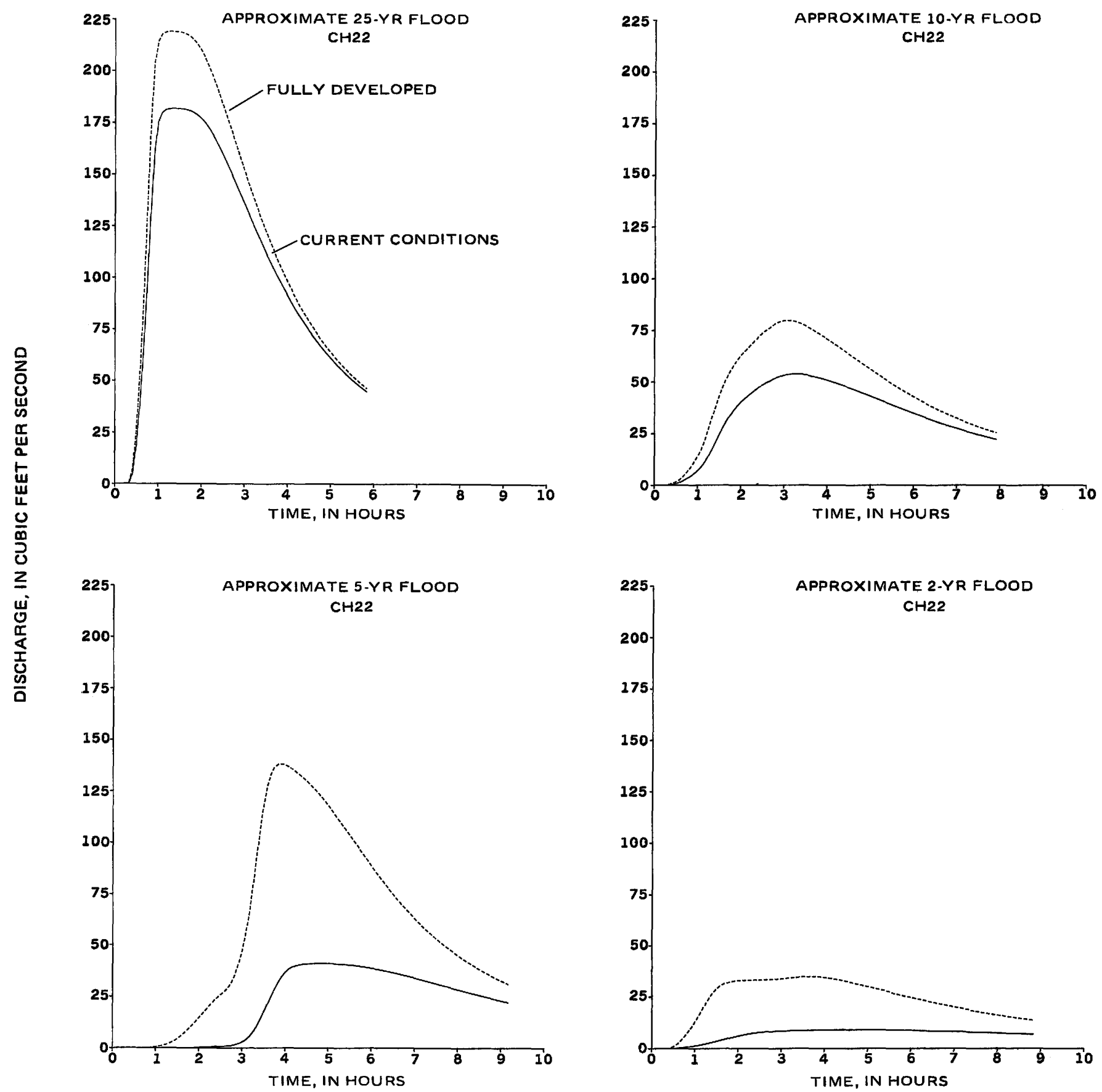

Figure 30. Comparison of approximate 2-, 5-, 10-, and 25-year hydrographs for subbasin $\mathrm{CH} 22$ in the Pheasant Branch drainage basin. 
APPROXIMATE 25-YR FLOOD CH22

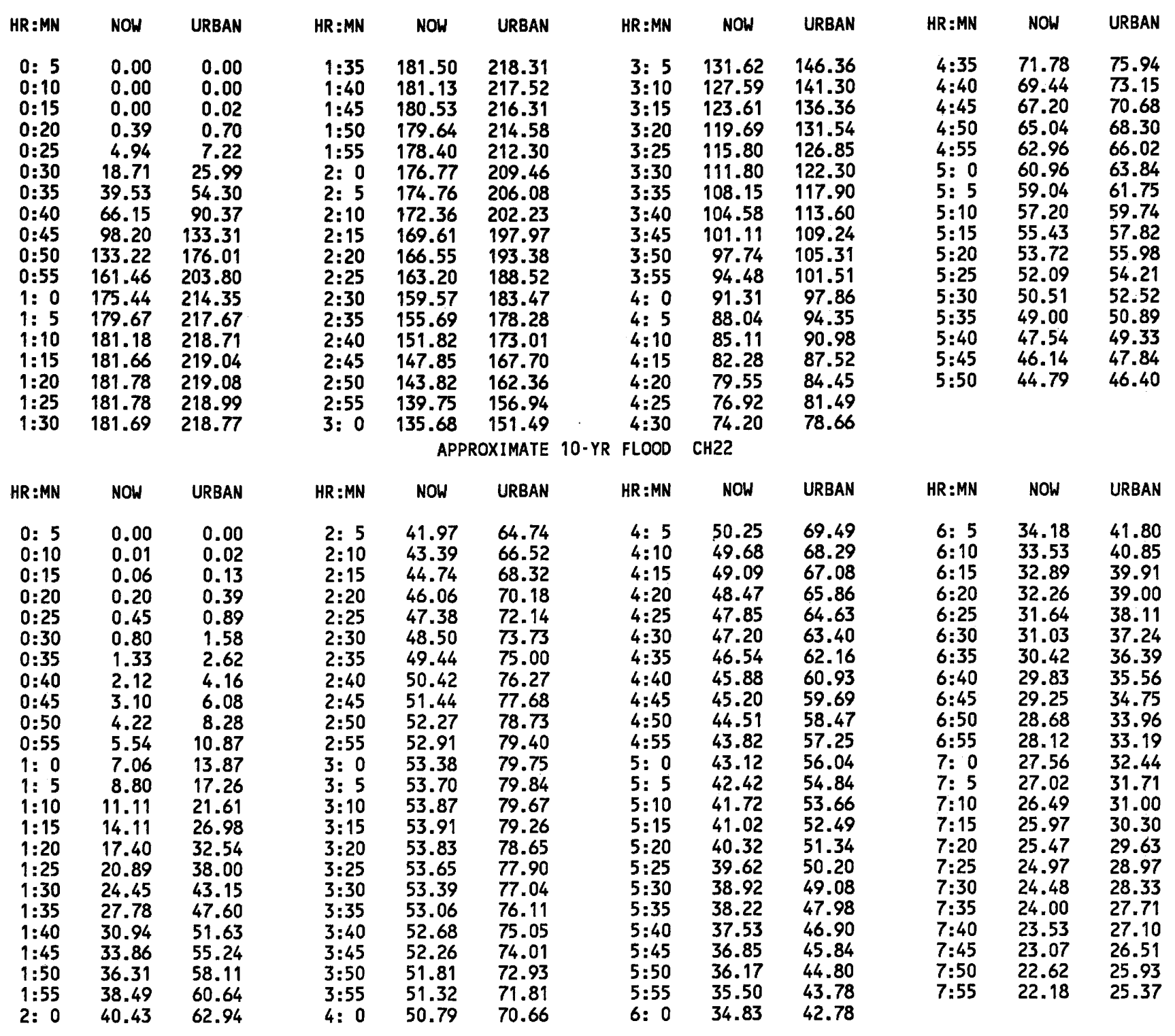


APPROXIMATE 5-YR FLOOD CH22

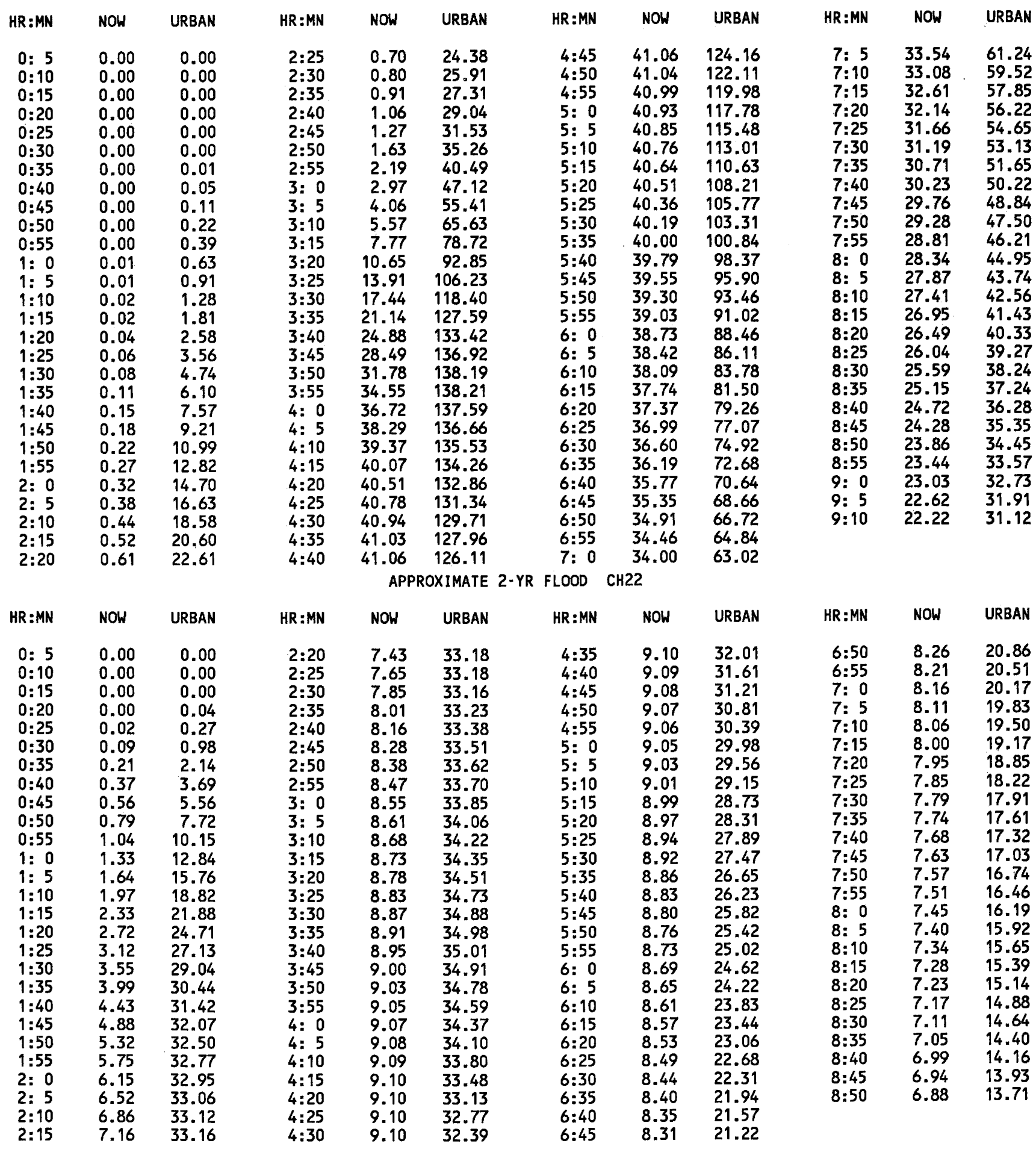



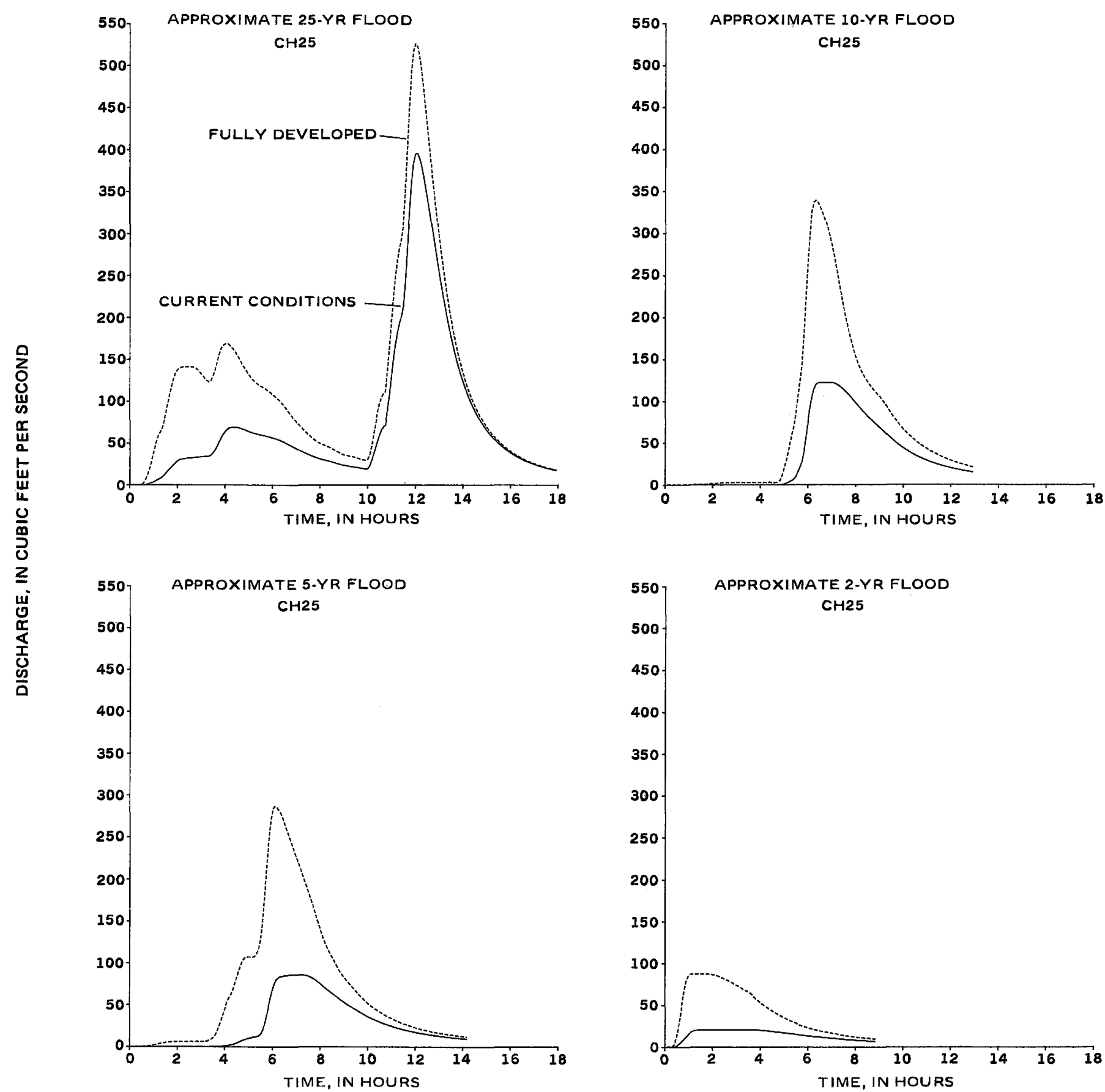

Figure 31. Comparison of approximate 2-, 5-, 10-, and 25-year hydrographs for subbasin $\mathrm{CH} 25$ in the Pheasant Branch drainage basin. 
APPROXIMATE 25-YR FLOOD CH25

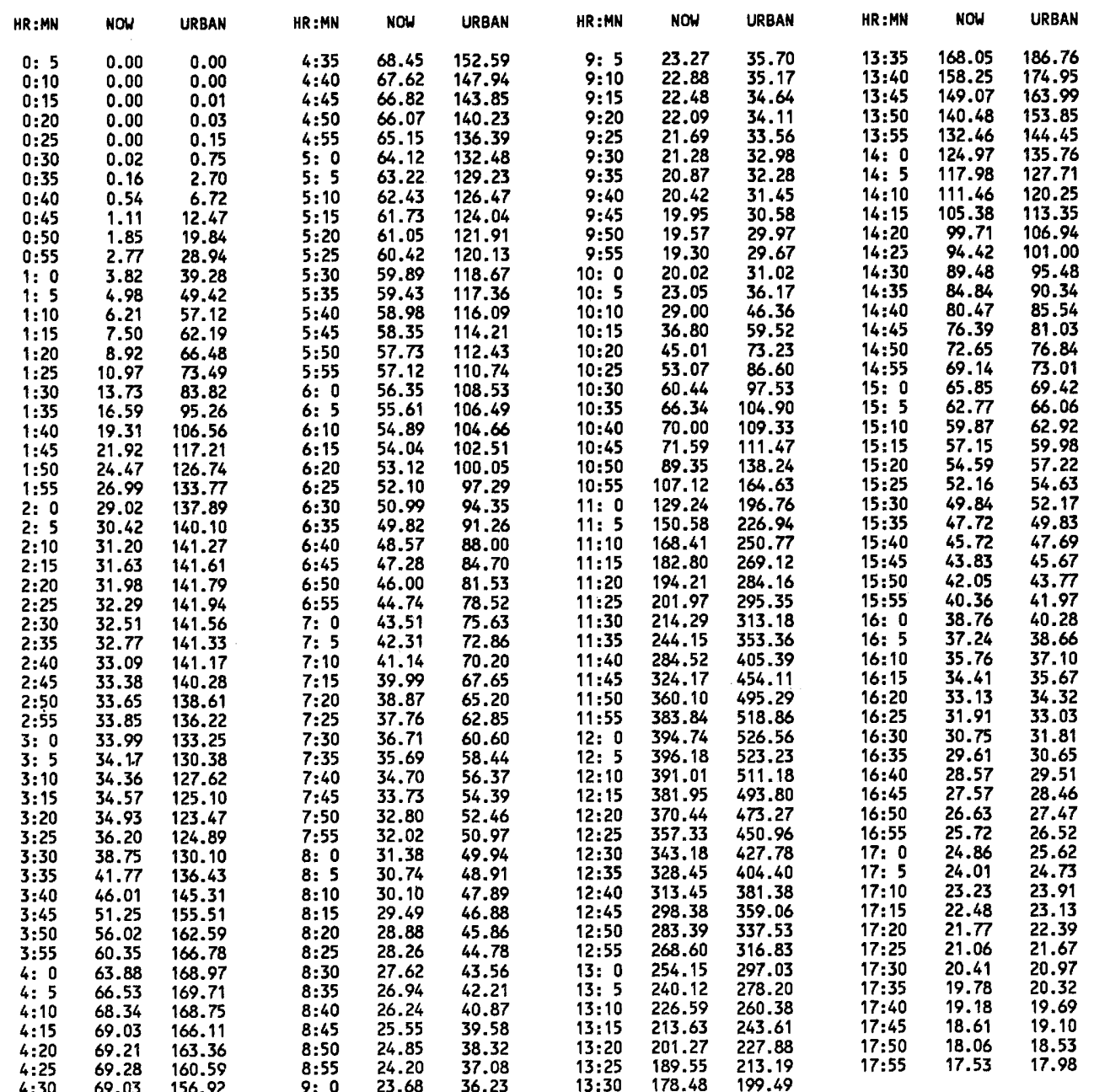

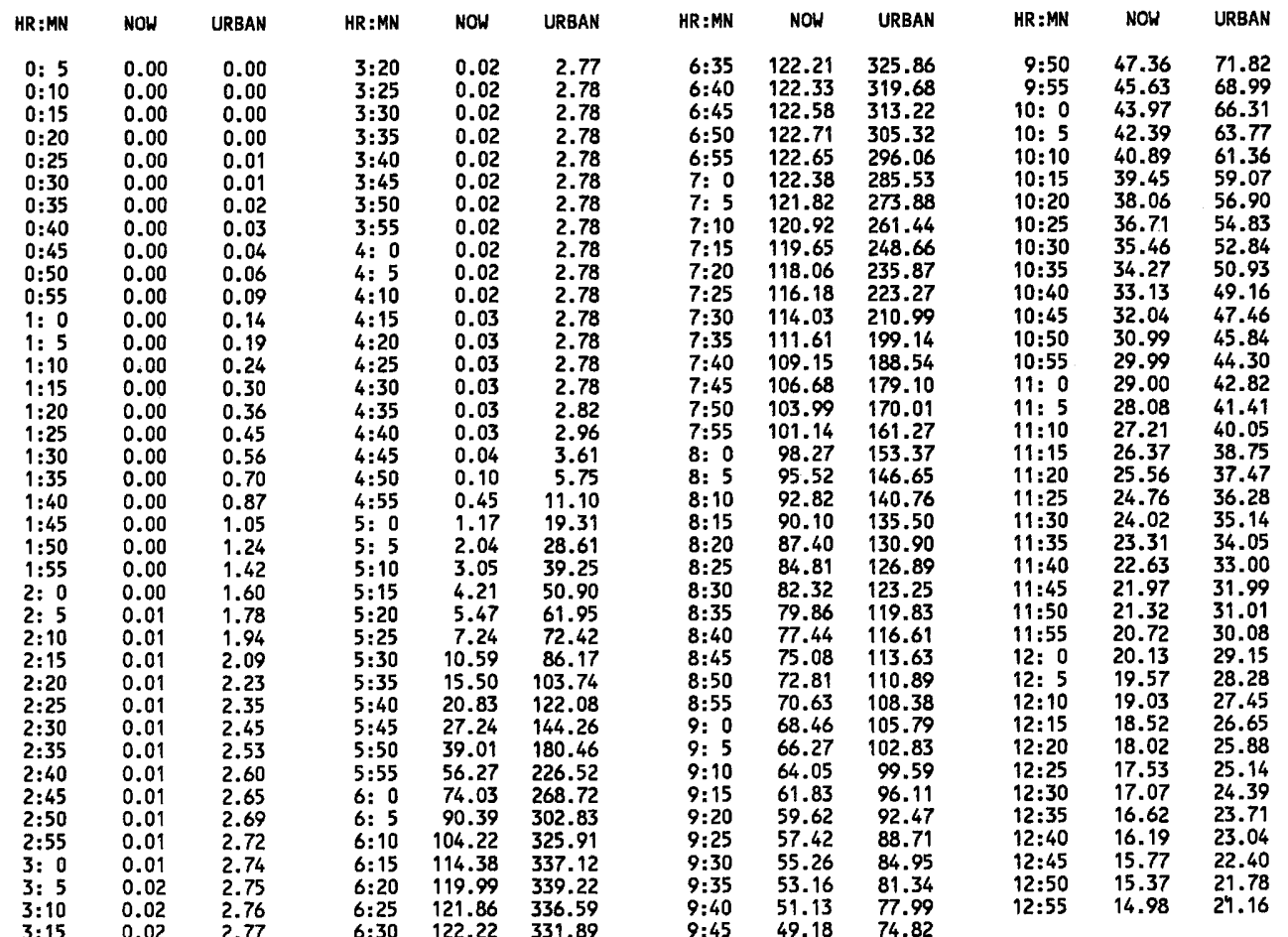


APPROXIMATE 5-YR FLOOD CH25

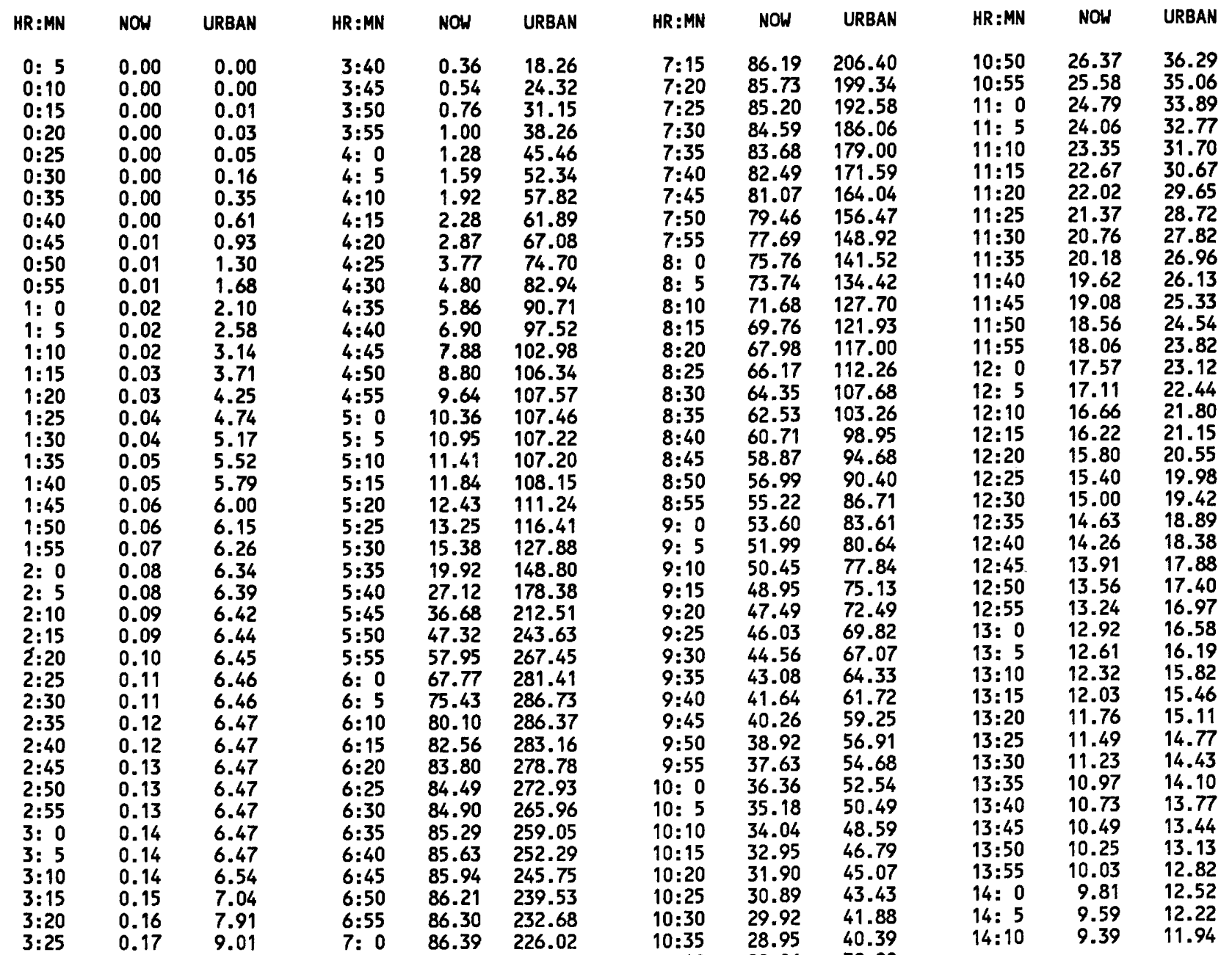

\begin{tabular}{|c|c|c|c|c|c|c|c|c|c|c|c|}
\hline HR:MN & NOW & URBAN & HR:MN & NOW & URBAN & HR:MN & NOW & URBAN & $H R: M N$ & NOW & URBAN \\
\hline $\begin{array}{l}0: 5 \\
0: 10 \\
0: 15 \\
0: 20 \\
0: 25 \\
0: 30 \\
0: 35 \\
0: 40 \\
0: 45 \\
0: 50 \\
0: 55 \\
1: 0 \\
1: 5 \\
1: 10 \\
1: 15 \\
1: 20 \\
1: 25 \\
1: 30 \\
1: 35 \\
1: 40 \\
1: 45 \\
1: 50 \\
1: 55 \\
2: 0 \\
2: 5 \\
2: 10 \\
2: 15\end{array}$ & $\begin{array}{c}0.00 \\
0.00 \\
0.00 \\
0.05 \\
0.52 \\
1.79 \\
3.56 \\
5.61 \\
7.87 \\
10.30 \\
12.88 \\
15.52 \\
17.85 \\
19.40 \\
20.19 \\
20.53 \\
20.66 \\
20.71 \\
20.73 \\
20.74 \\
20.74 \\
20.74 \\
20.74 \\
20.74 \\
20.74 \\
20.74 \\
20.73\end{array}$ & $\begin{array}{r}0.00 \\
0.01 \\
0.13 \\
1.07 \\
5.17 \\
14.07 \\
26.23 \\
40.39 \\
55.67 \\
70.28 \\
80.85 \\
85.87 \\
87.32 \\
87.55 \\
87.57 \\
87.58 \\
87.57 \\
87.56 \\
87.54 \\
87.48 \\
87.39 \\
87.24 \\
86.99 \\
86.65 \\
86.16 \\
85.52 \\
84.72\end{array}$ & $\begin{array}{l}2: 20 \\
2: 25 \\
2: 30 \\
2: 35 \\
2: 40 \\
2: 45 \\
2: 50 \\
2: 55 \\
3: 0 \\
3: 5 \\
3: 10 \\
3: 15 \\
3: 20 \\
3: 25 \\
3: 30 \\
3: 35 \\
3: 40 \\
3: 45 \\
3: 50 \\
3: 55 \\
4: 0 \\
4: 5 \\
4: 10 \\
4: 15 \\
4: 20 \\
4: 25 \\
4: 30\end{array}$ & $\begin{array}{l}20.73 \\
20.72 \\
20.71 \\
20.73 \\
20.77 \\
20.80 \\
20.83 \\
20.84 \\
20.87 \\
20.92 \\
20.94 \\
20.94 \\
20.94 \\
20.95 \\
20.94 \\
20.90 \\
20.82 \\
20.60 \\
20.46 \\
20.29 \\
20.09 \\
19.88 \\
19.66 \\
19.42 \\
19.18 \\
18.93 \\
18.67\end{array}$ & $\begin{array}{l}83.73 \\
82.57 \\
81.24 \\
80.12 \\
79.19 \\
78.06 \\
76.76 \\
75.30 \\
74.03 \\
72.87 \\
71.41 \\
69.75 \\
68.35 \\
67.20 \\
65.86 \\
64.29 \\
62.60 \\
59.08 \\
57.17 \\
55.19 \\
53.23 \\
51.33 \\
49.54 \\
47.81 \\
46.15 \\
44.56 \\
43.02\end{array}$ & $\begin{array}{l}4: 35 \\
4: 40 \\
4: 45 \\
4: 50 \\
4: 55 \\
5: 0 \\
5: 5 \\
5: 10 \\
5: 15 \\
5: 20 \\
5: 25 \\
5: 30 \\
5: 35 \\
5: 40 \\
5: 45 \\
5: 50 \\
5: 55 \\
6: 0 \\
6: 5 \\
6: 10 \\
6: 15 \\
6: 20 \\
6: 25 \\
6: 30 \\
6: 35 \\
6: 40 \\
6: 45\end{array}$ & $\begin{array}{l}18.40 \\
18.13 \\
17.86 \\
17.58 \\
17.30 \\
17.02 \\
16.74 \\
16.45 \\
16.17 \\
15.88 \\
15.60 \\
15.31 \\
14.75 \\
14.48 \\
14.21 \\
13.94 \\
13.67 \\
13.41 \\
13.15 \\
12.89 \\
12.64 \\
12.40 \\
12.15 \\
11.91 \\
11.68 \\
11.45 \\
11.23\end{array}$ & $\begin{array}{l}41.55 \\
40.14 \\
38.78 \\
37.44 \\
36.20 \\
35.01 \\
33.87 \\
32.78 \\
31.73 \\
30.72 \\
29.72 \\
28.79 \\
27.05 \\
26.24 \\
25.45 \\
24.66 \\
23.94 \\
23.24 \\
22.57 \\
21.93 \\
21.28 \\
20.69 \\
20.12 \\
19.56 \\
19.03 \\
18.52 \\
18.02\end{array}$ & $\begin{array}{l}6: 50 \\
6: 55 \\
7: 0 \\
7: 5 \\
7: 10 \\
7: 15 \\
7: 20 \\
7: 25 \\
7: 30 \\
7: 35 \\
7: 40 \\
7: 45 \\
7: 50 \\
7: 55 \\
8: 0 \\
8: 5 \\
8: 10 \\
8: 15 \\
8: 20 \\
8: 25 \\
8: 30 \\
8: 35 \\
8: 40 \\
8: 45 \\
8: 50\end{array}$ & $\begin{array}{r}11.00 \\
10.79 \\
10.58 \\
10.37 \\
10.17 \\
9.97 \\
9.77 \\
9.40 \\
9.21 \\
9.04 \\
8.86 \\
8.69 \\
8.53 \\
8.36 \\
8.20 \\
8.05 \\
7.90 \\
7.75 \\
7.60 \\
7.46 \\
7.32 \\
7.19 \\
7.06 \\
6.93 \\
6.80\end{array}$ & $\begin{array}{r}17.54 \\
17.08 \\
16.64 \\
16.21 \\
15.80 \\
15.40 \\
15.01 \\
14.27 \\
13.92 \\
13.59 \\
13.26 \\
12.94 \\
12.64 \\
12.34 \\
12.05 \\
11.77 \\
11.50 \\
11.24 \\
10.99 \\
10.74 \\
10.50 \\
10.27 \\
10.05 \\
9.83 \\
9.63\end{array}$ \\
\hline
\end{tabular}



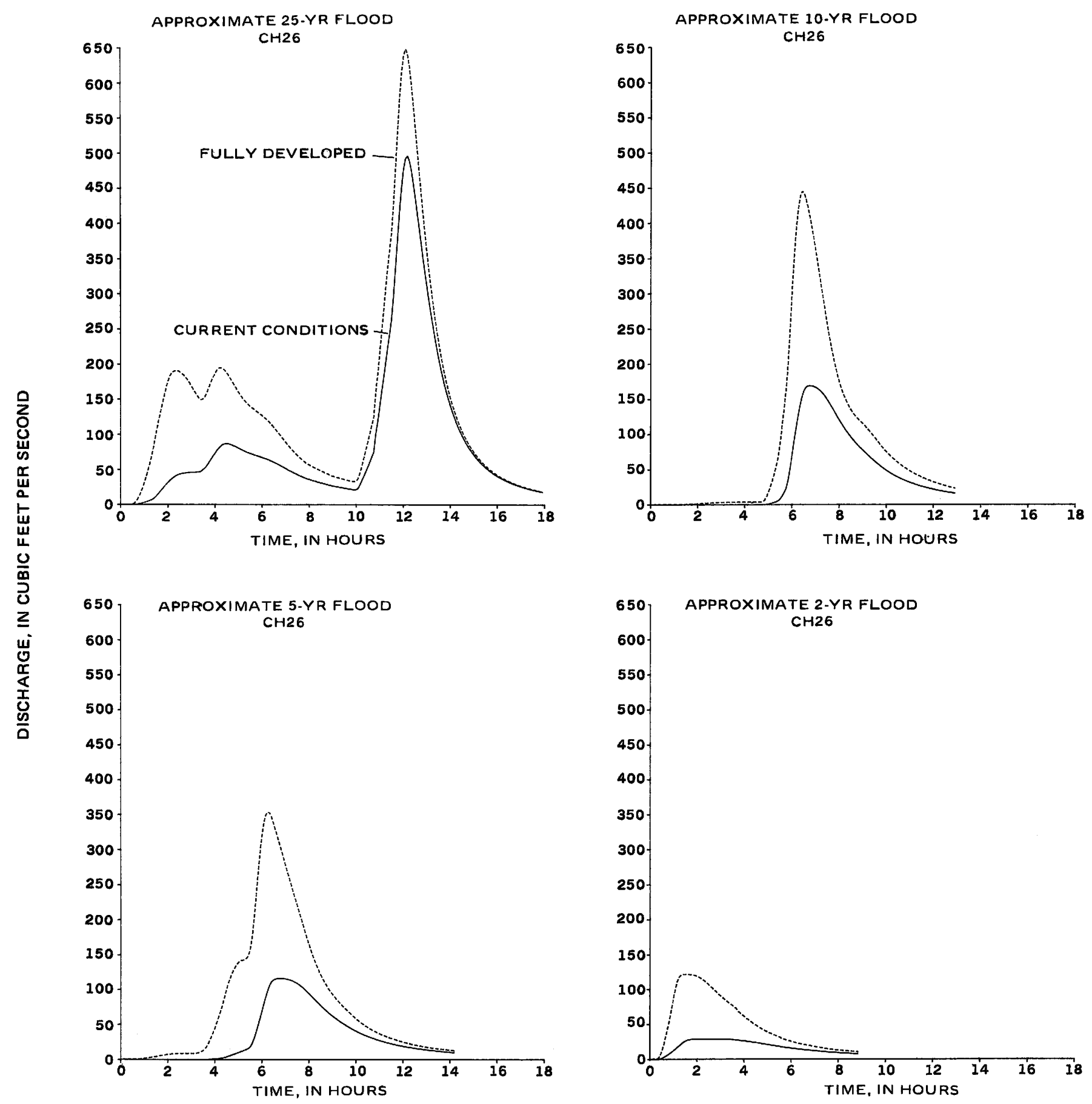

Figure 32. Comparison of approximate 2-, 5-, 10-, and 25-year hydrographs for subbasin CH26 in the Pheasant Branch drainage basin. 


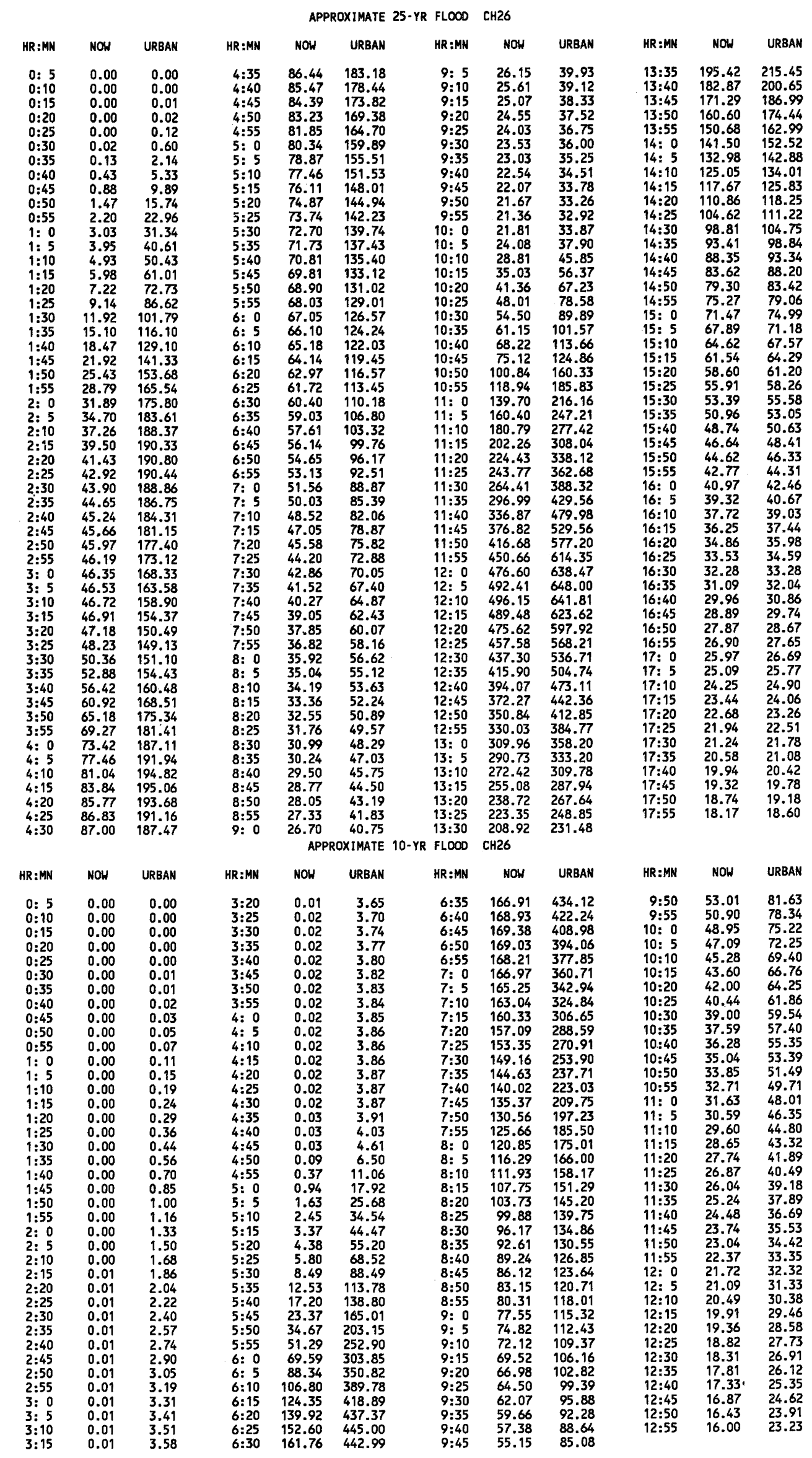


APPROXIMATE 5-YR FLOOD CH26

\begin{tabular}{|c|c|c|c|c|c|c|c|c|c|c|c|}
\hline HR:MN & NOW & URBAN & HR:MN & NOW & URBAN & HR:MN & NOW & URBAN & HR:MN & NOW & URBAN \\
\hline $\begin{array}{l}0: 5 \\
0: 10 \\
0: 15 \\
0: 20 \\
0: 25 \\
0: 30 \\
0: 35 \\
0: 40 \\
0: 45 \\
0: 50 \\
0: 55 \\
1: 0 \\
1: 5 \\
1: 10 \\
1: 15 \\
1: 20 \\
1: 25 \\
1: 30 \\
1: 35 \\
1: 40 \\
1: 45 \\
1: 50 \\
1: 55 \\
2: 0 \\
2: 5 \\
2: 10 \\
2: 15 \\
2: 20 \\
2: 25 \\
2: 30 \\
2: 35 \\
2: 40 \\
2: 45 \\
2: 50 \\
2: 55 \\
3: 0 \\
3: 5 \\
3: 10 \\
3: 15 \\
3: 20 \\
3: 25\end{array}$ & $\begin{array}{l}0.00 \\
0.00 \\
0.00 \\
0.00 \\
0.00 \\
0.00 \\
0.00 \\
0.00 \\
0.00 \\
0.01 \\
0.01 \\
0.01 \\
0.02 \\
0.02 \\
0.02 \\
0.03 \\
0.03 \\
0.03 \\
0.04 \\
0.04 \\
0.05 \\
0.05 \\
0.06 \\
0.06 \\
0.07 \\
0.07 \\
0.08 \\
0.08 \\
0.09 \\
0.09 \\
0.10 \\
0.10 \\
0.11 \\
0.11 \\
0.12 \\
0.12 \\
0.13 \\
0.13 \\
0.14 \\
0.16 \\
0.17\end{array}$ & $\begin{array}{l}0.00 \\
0.00 \\
0.01 \\
0.02 \\
0.04 \\
0.12 \\
0.27 \\
0.48 \\
0.74 \\
1.03 \\
1.34 \\
1.66 \\
2.05 \\
2.50 \\
2.98 \\
3.47 \\
3.98 \\
4.51 \\
5.04 \\
5.58 \\
6.11 \\
6.61 \\
7.08 \\
7.49 \\
7.84 \\
8.13 \\
8.36 \\
8.54 \\
8.67 \\
8.77 \\
8.85 \\
8.90 \\
8.93 \\
8.96 \\
8.98 \\
8.99 \\
8.99 \\
9.06 \\
9.52 \\
10.31 \\
11.30\end{array}$ & $\begin{array}{l}3: 40 \\
3: 45 \\
3: 50 \\
3: 55 \\
4: 0 \\
4: 5 \\
4: 10 \\
4: 15 \\
4: 20 \\
4: 25 \\
4: 30 \\
4: 35 \\
4: 40 \\
4: 45 \\
4: 50 \\
4: 55 \\
5: 0 \\
5: 5 \\
5: 10 \\
5: 15 \\
5: 20 \\
5: 25 \\
5: 30 \\
5: 35 \\
5: 40 \\
5: 45 \\
5: 50 \\
5: 55 \\
6: 0 \\
6: 5 \\
6: 10 \\
6: 15 \\
6: 20 \\
6: 25 \\
6: 30 \\
6: 35 \\
6: 40 \\
6: 45 \\
6: 50 \\
6: 55 \\
7: 0\end{array}$ & $\begin{array}{r}0.34 \\
0.49 \\
0.67 \\
0.88 \\
1.12 \\
1.38 \\
1.66 \\
1.96 \\
2.46 \\
3.22 \\
4.11 \\
5.07 \\
6.07 \\
7.11 \\
8.17 \\
9.24 \\
10.29 \\
11.34 \\
12.37 \\
13.42 \\
14.62 \\
15.97 \\
18.42 \\
22.87 \\
29.68 \\
38.46 \\
47.94 \\
57.89 \\
68.15 \\
78.67 \\
88.97 \\
98.56 \\
106.49 \\
111.78 \\
114.51 \\
115.78 \\
116.33 \\
116.54 \\
116.55 \\
116.22 \\
115.72\end{array}$ & $\begin{array}{r}19.41 \\
24.72 \\
30.68 \\
37.32 \\
44.57 \\
52.49 \\
60.63 \\
68.76 \\
78.28 \\
89.45 \\
100.28 \\
109.75 \\
117.83 \\
124.87 \\
130.90 \\
135.83 \\
139.45 \\
141.84 \\
142.76 \\
143.30 \\
145.13 \\
148.64 \\
157.72 \\
175.31 \\
201.10 \\
232.40 \\
264.19 \\
294.10 \\
319.64 \\
338.79 \\
350.23 \\
354.19 \\
352.33 \\
345.96 \\
337.01 \\
327.47 \\
317.83 \\
308.21 \\
298.64 \\
288.37 \\
278.31\end{array}$ & $\begin{array}{c}7: 15 \\
7: 20 \\
7: 25 \\
7: 30 \\
7: 35 \\
7: 40 \\
7: 45 \\
7: 50 \\
7: 55 \\
8: 0 \\
8: 5 \\
8: 10 \\
8: 15 \\
8: 20 \\
8: 25 \\
8: 30 \\
8: 35 \\
8: 40 \\
8: 45 \\
8: 50 \\
8: 55 \\
9: 0 \\
9: 5 \\
9: 10 \\
9: 15 \\
9: 20 \\
9: 25 \\
9: 30 \\
9: 35 \\
9: 40 \\
9: 45 \\
9: 50 \\
9: 55 \\
10: 0 \\
10: 5 \\
10: 10 \\
10: 15 \\
10: 20 \\
10: 25 \\
10: 30 \\
10: 35\end{array}$ & $\begin{array}{l}113.33 \\
112.09 \\
110.67 \\
109.08 \\
107.20 \\
105.06 \\
102.70 \\
100.13 \\
97.37 \\
94.46 \\
91.46 \\
88.44 \\
85.50 \\
82.68 \\
79.88 \\
77.12 \\
74.41 \\
71.74 \\
69.20 \\
66.73 \\
64.44 \\
62.31 \\
60.17 \\
58.11 \\
56.12 \\
54.18 \\
52.27 \\
50.48 \\
48.75 \\
47.09 \\
45.43 \\
43.86 \\
42.32 \\
40.80 \\
39.38 \\
37.98 \\
36.68 \\
35.43 \\
34.24 \\
33.10 \\
32.01\end{array}$ & $\begin{array}{l}249.69 \\
239.89 \\
230.35 \\
221.17 \\
211.79 \\
202.37 \\
192.98 \\
183.67 \\
174.50 \\
165.60 \\
157.01 \\
148.73 \\
141.24 \\
134.58 \\
128.24 \\
122.23 \\
116.59 \\
111.32 \\
106.35 \\
101.66 \\
97.56 \\
93.93 \\
90.30 \\
86.73 \\
83.37 \\
80.16 \\
77.13 \\
74.22 \\
71.42 \\
68.74 \\
66.10 \\
63.48 \\
60.93 \\
58.44 \\
56.14 \\
53.94 \\
51.81 \\
49.84 \\
47.97 \\
46.14 \\
44.45\end{array}$ & $\begin{array}{l}10: 50 \\
10: 55 \\
11: 0 \\
11: 5 \\
11: 10 \\
11: 15 \\
11: 20 \\
11: 25 \\
11: 30 \\
11: 35 \\
11: 40 \\
11: 45 \\
11: 50 \\
11: 55 \\
12: 0 \\
12: 5 \\
12: 10 \\
12: 15 \\
12: 20 \\
12: 25 \\
12: 30 \\
12: 35 \\
12: 40 \\
12: 45 \\
12: 50 \\
12: 55 \\
13: 0 \\
13: 55 \\
13: 10 \\
13: 15 \\
13: 20 \\
13: 25 \\
13: 30 \\
13: 35 \\
13: 40 \\
13: 45 \\
13: 50 \\
13: 55 \\
14: 0 \\
14: 5 \\
14: 10\end{array}$ & $\begin{array}{l}29.00 \\
28.07 \\
27.19 \\
26.34 \\
25.53 \\
24.75 \\
24.00 \\
23.28 \\
22.59 \\
21.93 \\
21.29 \\
20.68 \\
20.09 \\
19.52 \\
18.97 \\
18.44 \\
17.94 \\
17.45 \\
16.98 \\
16.53 \\
16.09 \\
15.66 \\
15.26 \\
14.86 \\
14.48 \\
14.12 \\
13.77 \\
13.43 \\
13.10 \\
12.78 \\
12.48 \\
12.18 \\
11.89 \\
11.61 \\
11.35 \\
11.08 \\
10.83 \\
10.59 \\
10.35 \\
10.12 \\
9.89\end{array}$ & $\begin{array}{l}39.81 \\
38.42 \\
37.06 \\
35.80 \\
34.59 \\
33.44 \\
32.34 \\
31.28 \\
30.27 \\
29.30 \\
28.38 \\
27.49 \\
26.64 \\
25.82 \\
25.04 \\
24.29 \\
23.56 \\
22.87 \\
22.20 \\
21.56 \\
20.94 \\
20.35 \\
19.78 \\
19.23 \\
18.70 \\
18.21 \\
17.75 \\
17.31 \\
16.89 \\
16.48 \\
16.08 \\
15.69 \\
15.32 \\
14.96 \\
14.61 \\
14.27 \\
13.94 \\
13.62 \\
13.30 \\
13.00 \\
12.70\end{array}$ \\
\hline
\end{tabular}

\begin{tabular}{|c|c|c|c|c|c|c|c|c|c|c|c|}
\hline HR:MN & NOW & URBAN & HR :MN & NOW & URBAN & $H R: M N$ & NOW & URBAN & HR:MN & NOW & URBAN \\
\hline $\begin{array}{l}0: 5 \\
0: 10 \\
0: 15 \\
0: 20 \\
0: 25 \\
0: 30 \\
0: 35 \\
0: 40 \\
0: 45 \\
0: 50 \\
0: 55 \\
1: 0 \\
1: 5 \\
1: 10 \\
1: 15 \\
1: 20 \\
1: 25 \\
1: 30 \\
1: 35 \\
1: 40 \\
1: 45 \\
1: 50 \\
1: 55 \\
2: 0 \\
2: 5 \\
2: 10 \\
2: 15\end{array}$ & $\begin{array}{l}0.00 \\
0.00 \\
0.00 \\
0.04 \\
0.42 \\
1.42 \\
2.82 \\
4.45 \\
6.24 \\
8.17 \\
10.22 \\
12.38 \\
14.64 \\
16.98 \\
19.40 \\
21.83 \\
24.08 \\
25.91 \\
27.19 \\
27.98 \\
28.42 \\
28.66 \\
28.77 \\
28.83 \\
28.85 \\
28.86 \\
28.85\end{array}$ & $\begin{array}{r}0.00 \\
0.00 \\
0.10 \\
0.85 \\
4.10 \\
11.16 \\
20.81 \\
32.04 \\
44.36 \\
57.60 \\
71.63 \\
86.21 \\
100.32 \\
111.65 \\
118.30 \\
120.94 \\
121.72 \\
121.85 \\
121.78 \\
121.57 \\
121.22 \\
120.68 \\
119.91 \\
118.87 \\
117.55 \\
115.92 \\
113.99\end{array}$ & $\begin{array}{l}2: 20 \\
2: 25 \\
2: 30 \\
2: 35 \\
2: 40 \\
2: 45 \\
2: 50 \\
2: 55 \\
3: 0 \\
3: 55 \\
3: 10 \\
3: 15 \\
3: 20 \\
3: 25 \\
3: 30 \\
3: 35 \\
3: 40 \\
3: 45 \\
3: 50 \\
3: 55 \\
4: 0 \\
4: 5 \\
4: 10 \\
4: 15 \\
4: 20 \\
4: 25 \\
4: 30\end{array}$ & $\begin{array}{l}28.83 \\
28.80 \\
28.76 \\
28.74 \\
28.73 \\
28.71 \\
28.66 \\
28.60 \\
28.53 \\
28.48 \\
28.39 \\
28.28 \\
28.17 \\
28.05 \\
27.90 \\
27.72 \\
27.50 \\
26.98 \\
26.67 \\
26.34 \\
25.99 \\
25.62 \\
25.22 \\
24.81 \\
24.39 \\
23.95 \\
23.51\end{array}$ & $\begin{array}{r}111.77 \\
109.27 \\
106.54 \\
103.93 \\
101.46 \\
98.81 \\
96.01 \\
93.12 \\
90.51 \\
88.14 \\
85.72 \\
83.25 \\
80.99 \\
78.90 \\
76.72 \\
74.50 \\
72.26 \\
67.86 \\
65.61 \\
63.37 \\
61.16 \\
58.93 \\
56.74 \\
54.61 \\
52.54 \\
50.51 \\
48.63\end{array}$ & $\begin{array}{l}4: 35 \\
4: 40 \\
4: 45 \\
4: 50 \\
4: 55 \\
5: 0 \\
5: 5 \\
5: 10 \\
5: 15 \\
5: 20 \\
5: 25 \\
5: 30 \\
5: 35 \\
5: 40 \\
5: 45 \\
5: 50 \\
5: 55 \\
6: 0 \\
6: 5 \\
6: 10 \\
6: 15 \\
6: 20 \\
6: 25 \\
6: 30 \\
6: 35 \\
6: 40 \\
6: 45\end{array}$ & $\begin{array}{l}23.06 \\
22.60 \\
22.15 \\
21.70 \\
21.25 \\
20.81 \\
20.36 \\
19.93 \\
19.49 \\
19.07 \\
18.65 \\
18.24 \\
17.43 \\
17.04 \\
16.66 \\
16.29 \\
15.92 \\
15.56 \\
15.21 \\
14.87 \\
14.53 \\
14.21 \\
13.89 \\
13.58 \\
13.28 \\
12.98 \\
12.69\end{array}$ & $\begin{array}{l}46.83 \\
45.07 \\
43.44 \\
41.89 \\
40.36 \\
38.95 \\
37.56 \\
36.28 \\
35.05 \\
33.88 \\
32.75 \\
31.68 \\
29.67 \\
28.73 \\
27.83 \\
26.97 \\
26.14 \\
25.34 \\
24.58 \\
23.85 \\
23.15 \\
22.47 \\
21.82 \\
21.20 \\
20.60 \\
20.02 \\
19.47\end{array}$ & $\begin{array}{l}6: 50 \\
6: 55 \\
7: 0 \\
7: 5 \\
7: 10 \\
7: 15 \\
7: 20 \\
7: 25 \\
7: 30 \\
7: 35 \\
7: 40 \\
7: 45 \\
7: 50 \\
7: 55 \\
8: 0 \\
8: 5 \\
8: 10 \\
8: 15 \\
8: 20 \\
8: 25 \\
8: 30 \\
8: 35 \\
8: 40 \\
8: 45 \\
8: 50\end{array}$ & $\begin{array}{r}12.41 \\
12.14 \\
11.87 \\
11.61 \\
11.36 \\
11.11 \\
10.87 \\
10.41 \\
10.19 \\
9.97 \\
9.76 \\
9.56 \\
9.36 \\
9.17 \\
8.98 \\
8.79 \\
8.61 \\
8.44 \\
8.27 \\
8.10 \\
7.94 \\
7.78 \\
7.63 \\
7.48 \\
7.33\end{array}$ & $\begin{array}{l}18.93 \\
18.42 \\
17.92 \\
17.44 \\
16.98 \\
16.53 \\
16.10 \\
15.28 \\
14.90 \\
14.52 \\
14.16 \\
13.81 \\
13.48 \\
13.15 \\
12.83 \\
12.52 \\
12.23 \\
11.94 \\
11.66 \\
11.39 \\
11.13 \\
10.88 \\
10.63 \\
10.40 \\
10.18\end{array}$ \\
\hline
\end{tabular}



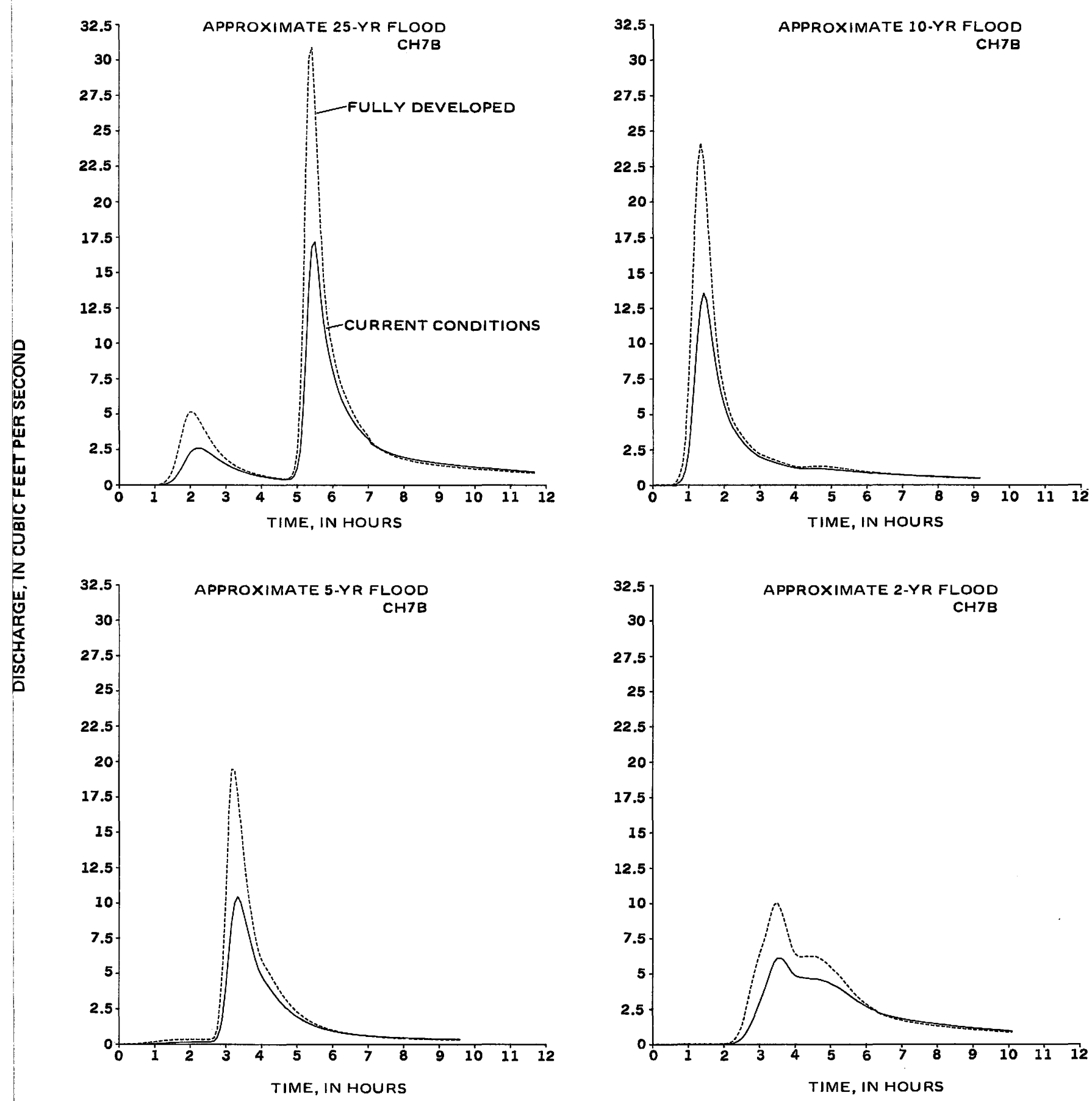

Figure 33. Comparison of approximate 2-, 5-, 10-, and 25-year hydrographs for subbasin CH7B in the Pheasant Branch drainage basin. 
APPROXIMATE 25-YR FLOOD CH7B

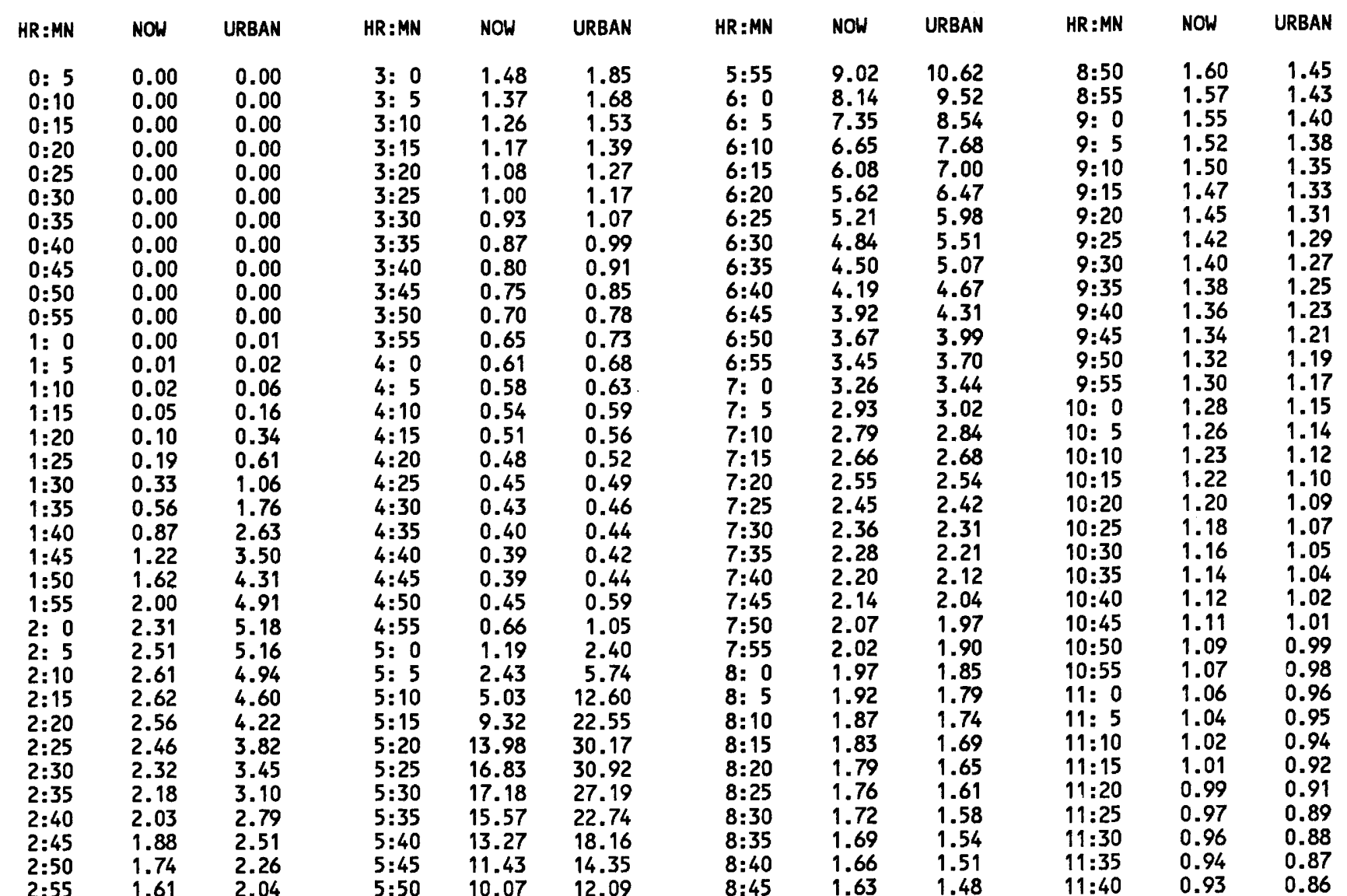

APPROXIMATE 10-YR FLOOD CH7B

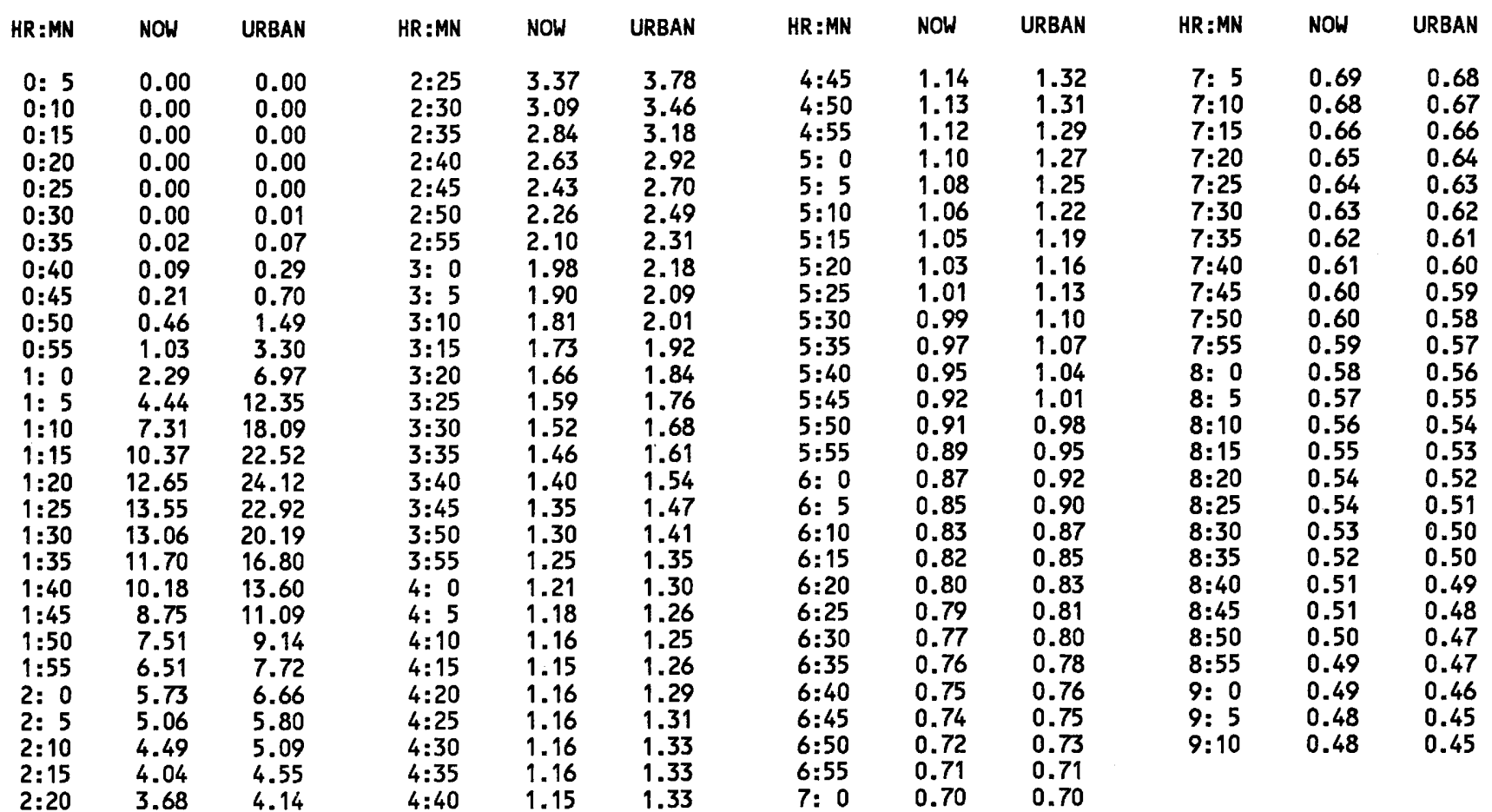


APPROXIMATE 5-YR FLOOD CH7B

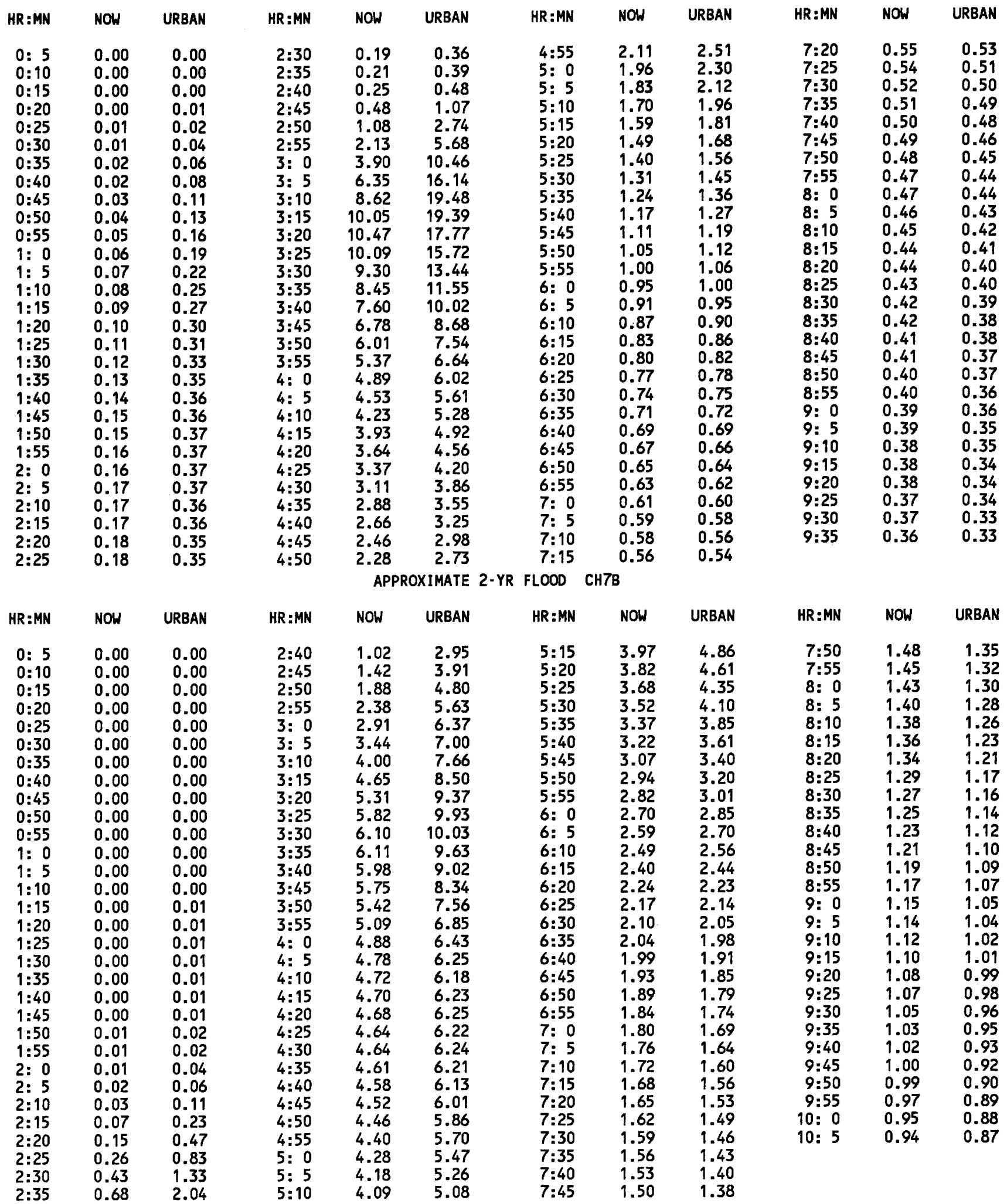



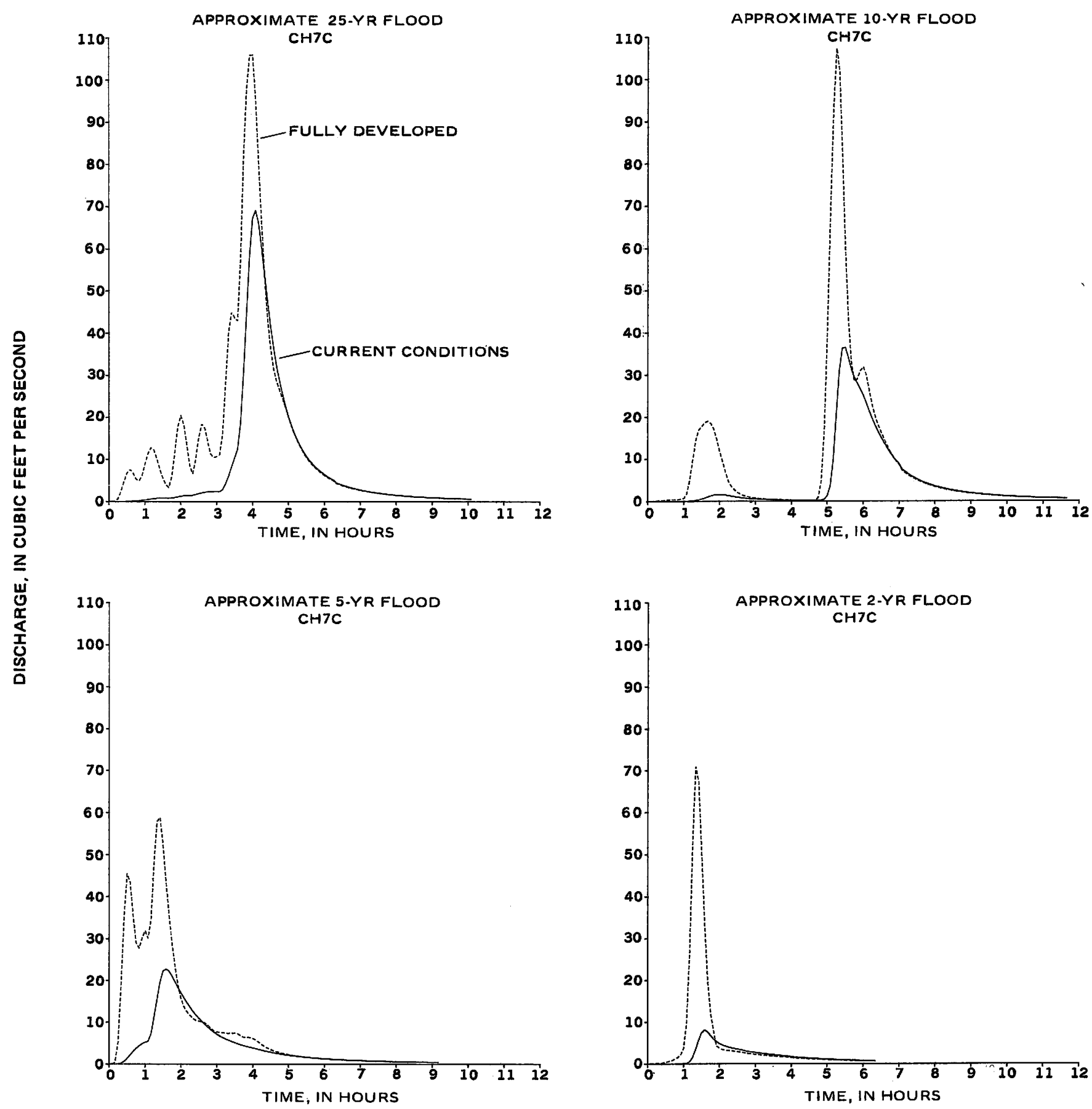

Figure 34. Comparison of approximate 2-, 5-, 10-, and 25-year hydrographs for subbasin CH7C in the Pheasant Branch drainage basin. 
APPROXIMATE 25-YR FLOOD CH7C

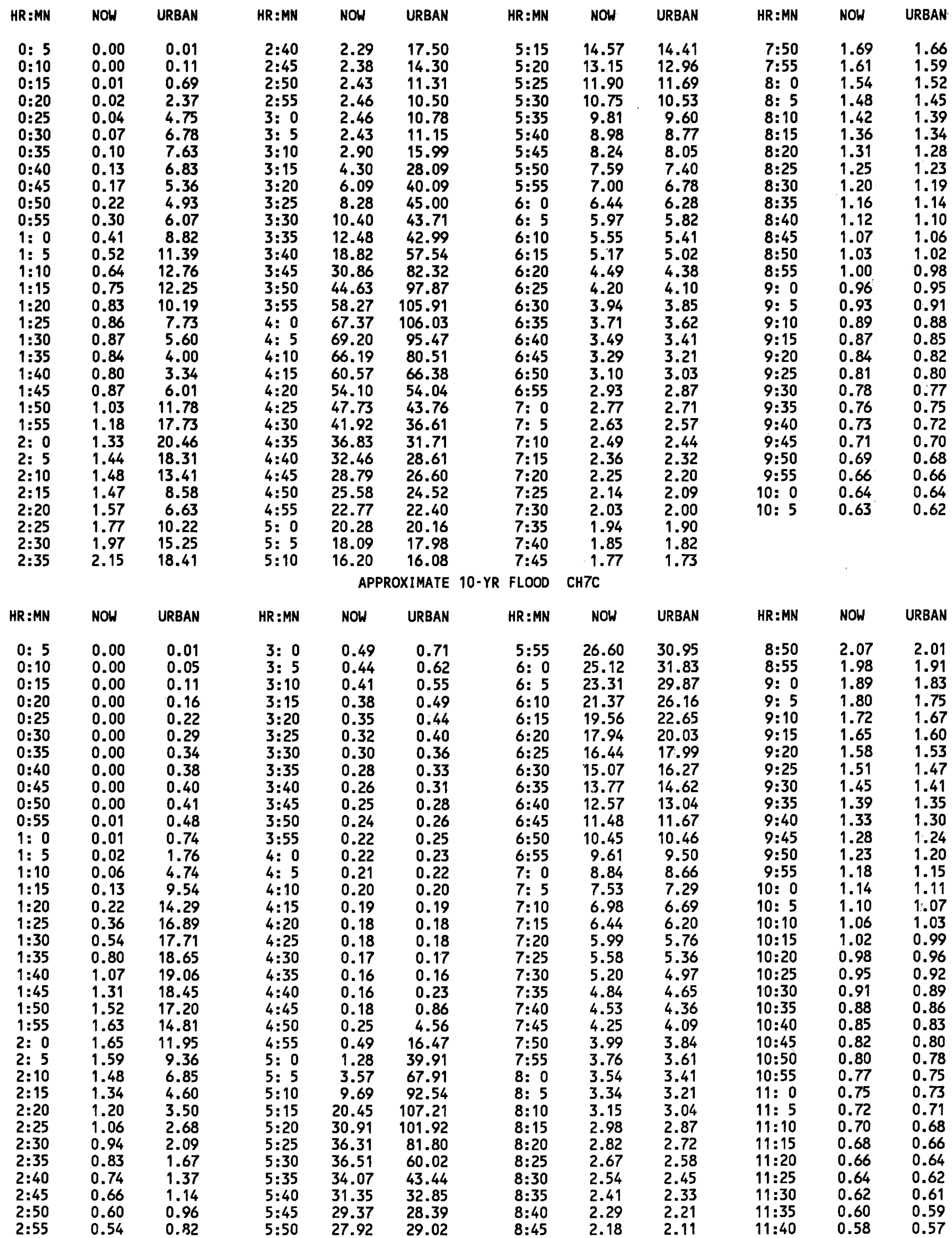


APPROXIMATE 5-YR FLOOD CH7C

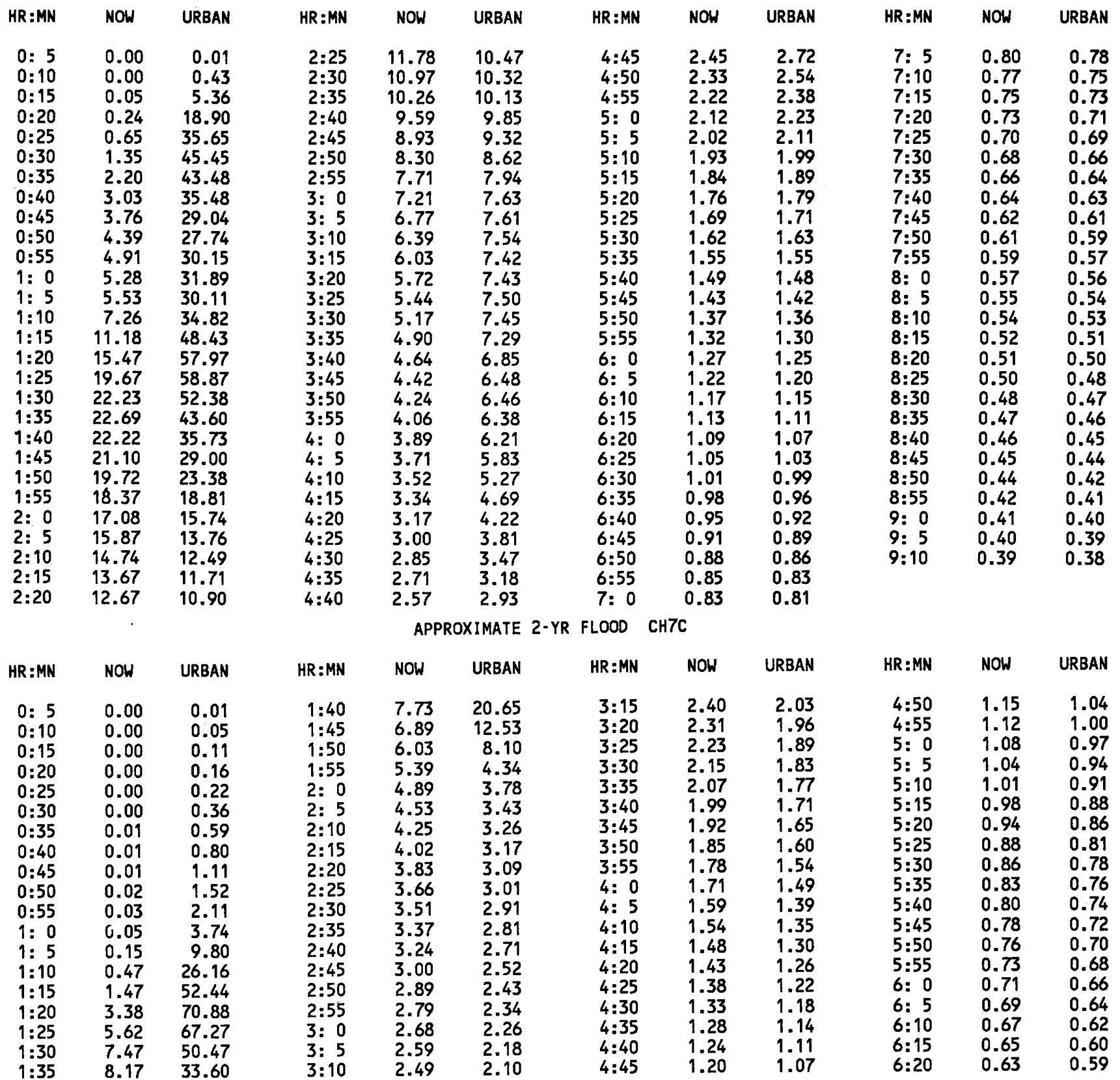



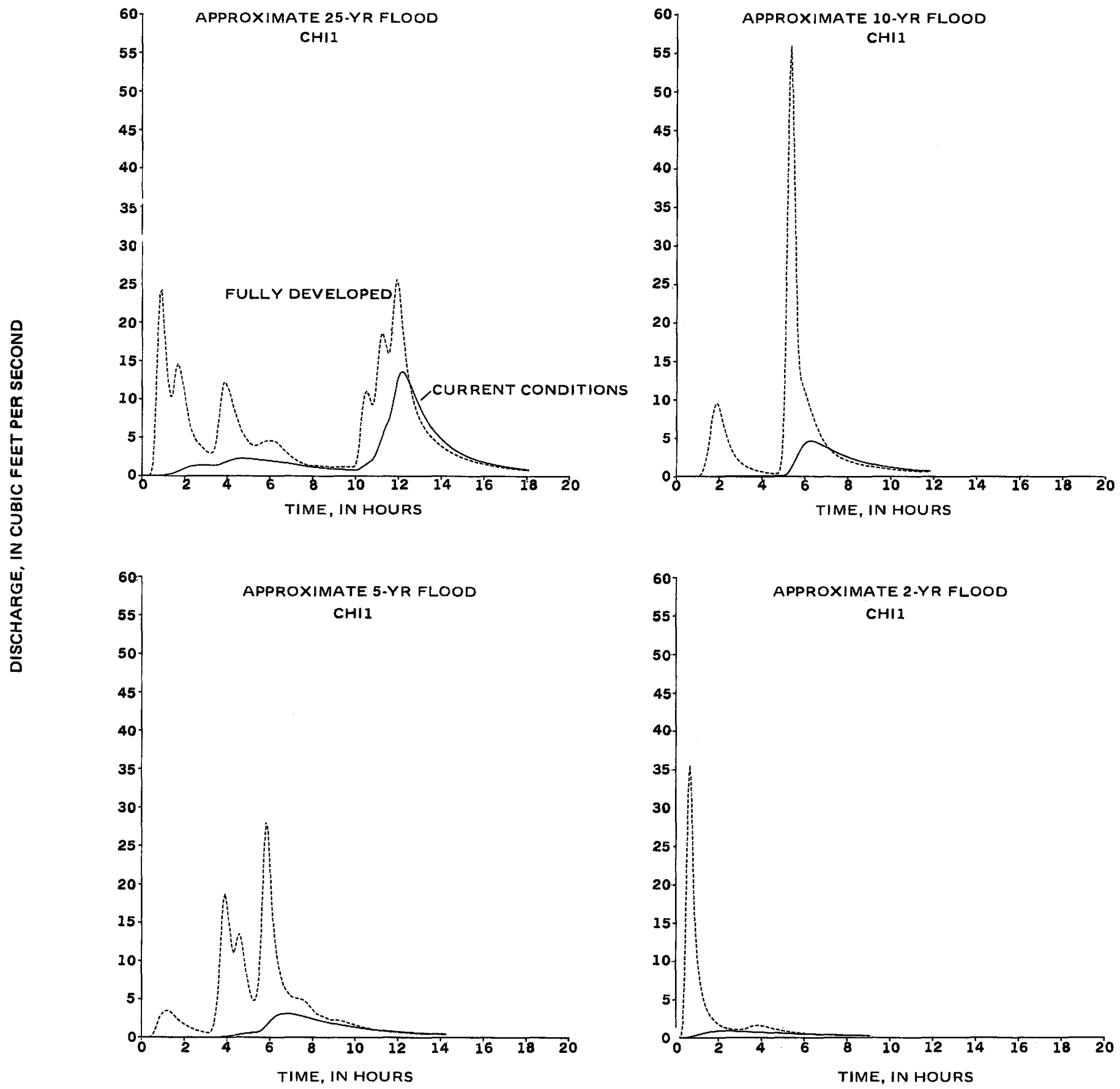

Figure 35. Comparison of approximate 2-, 5-, 10-, and 25-year hydrographs for subbasin CHI1 in the Pheasant Branch drainage basin. 
APPROXIMATE 25-YR FLOOD CHI1

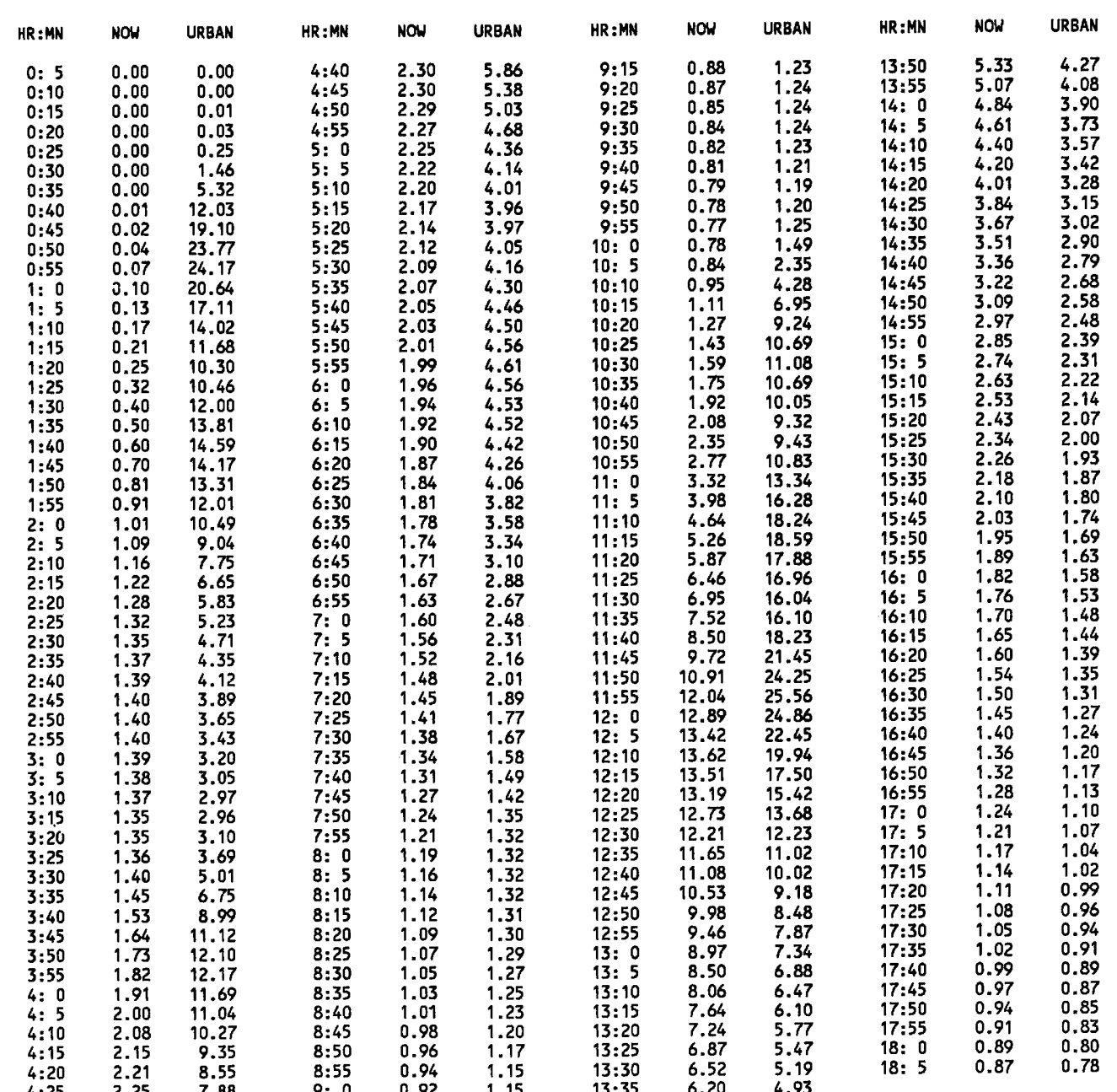

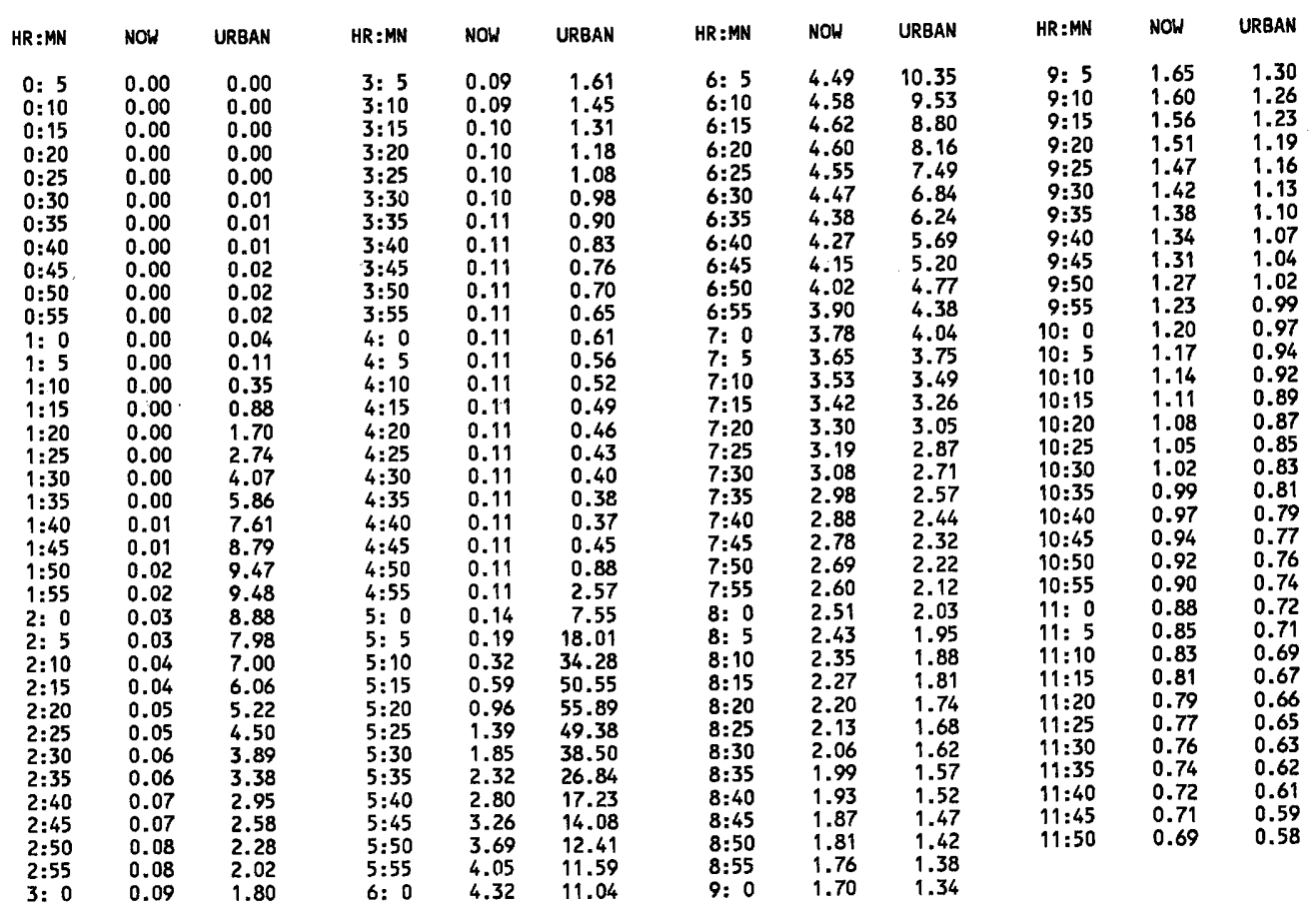


APPROXIMATE 5-YR FLOOD CHI1

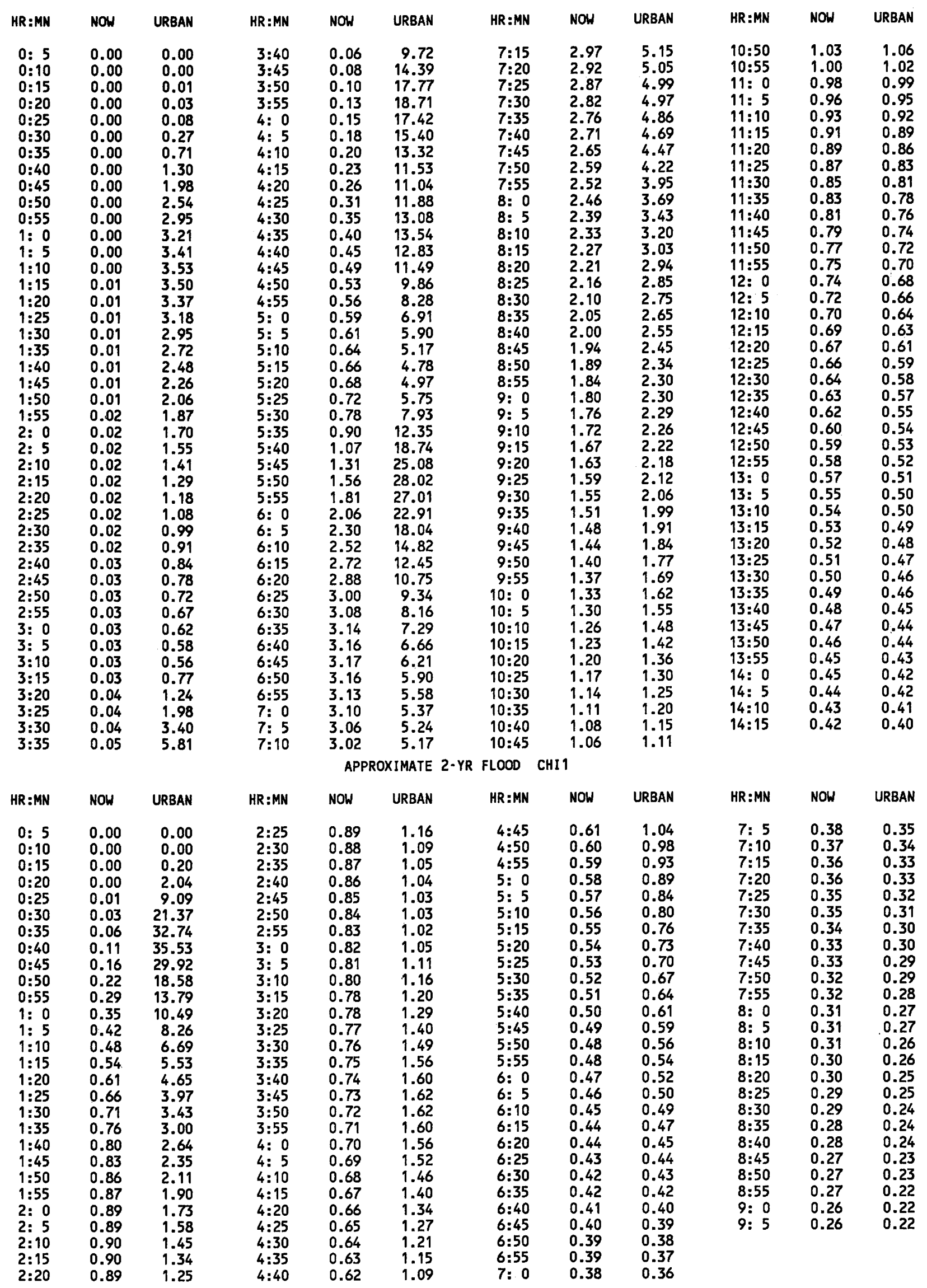



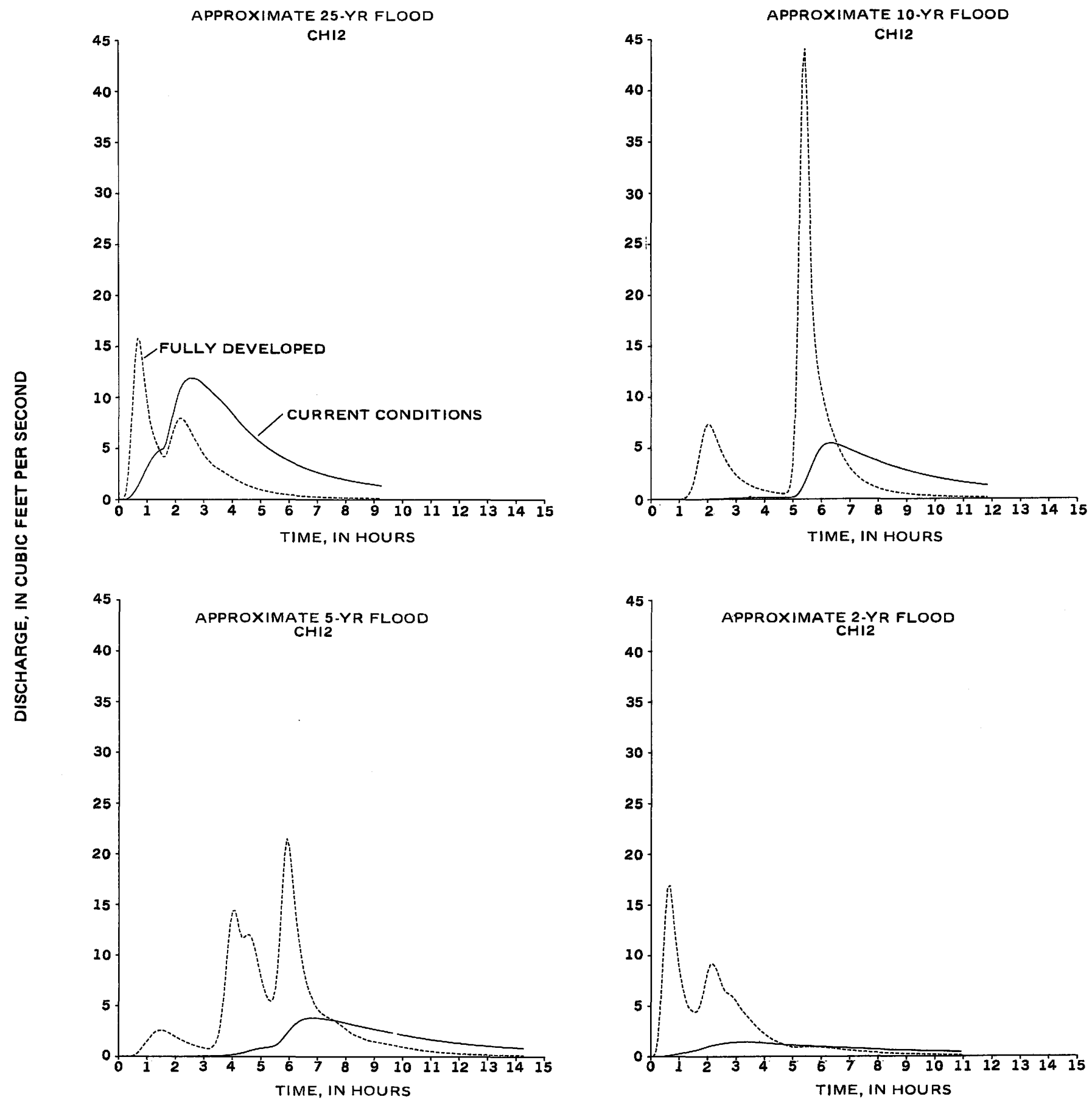

Figure 36. Comparison of approximate 2-, 5-, 10-, and 25-year hydrographs for subbasin CHI2 in the Pheasant Branch drainage basin. 
APPROXIMATE 25-YR FLOOD CHI2

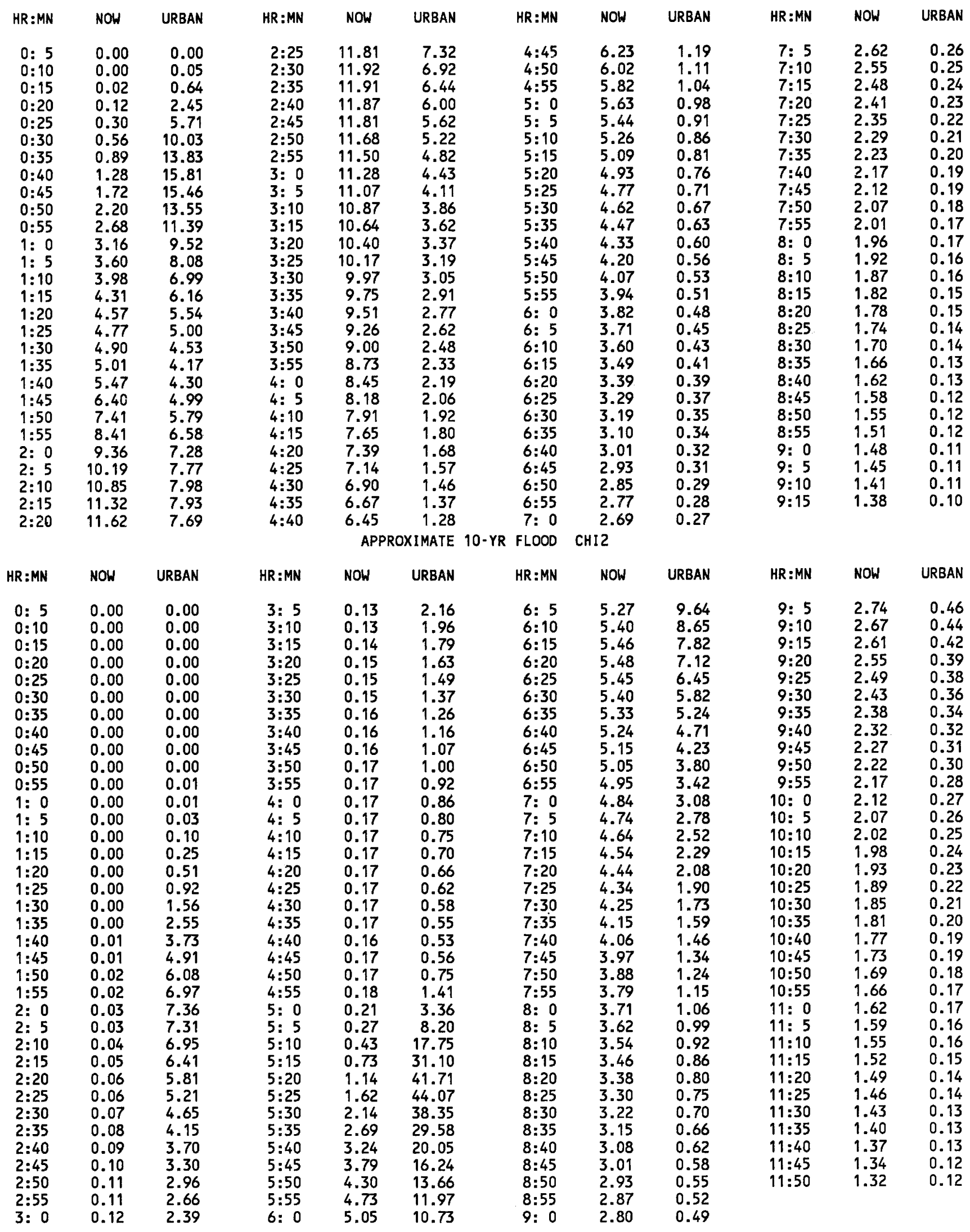


APPROXIMATE 5-YR FLOOD CHI2

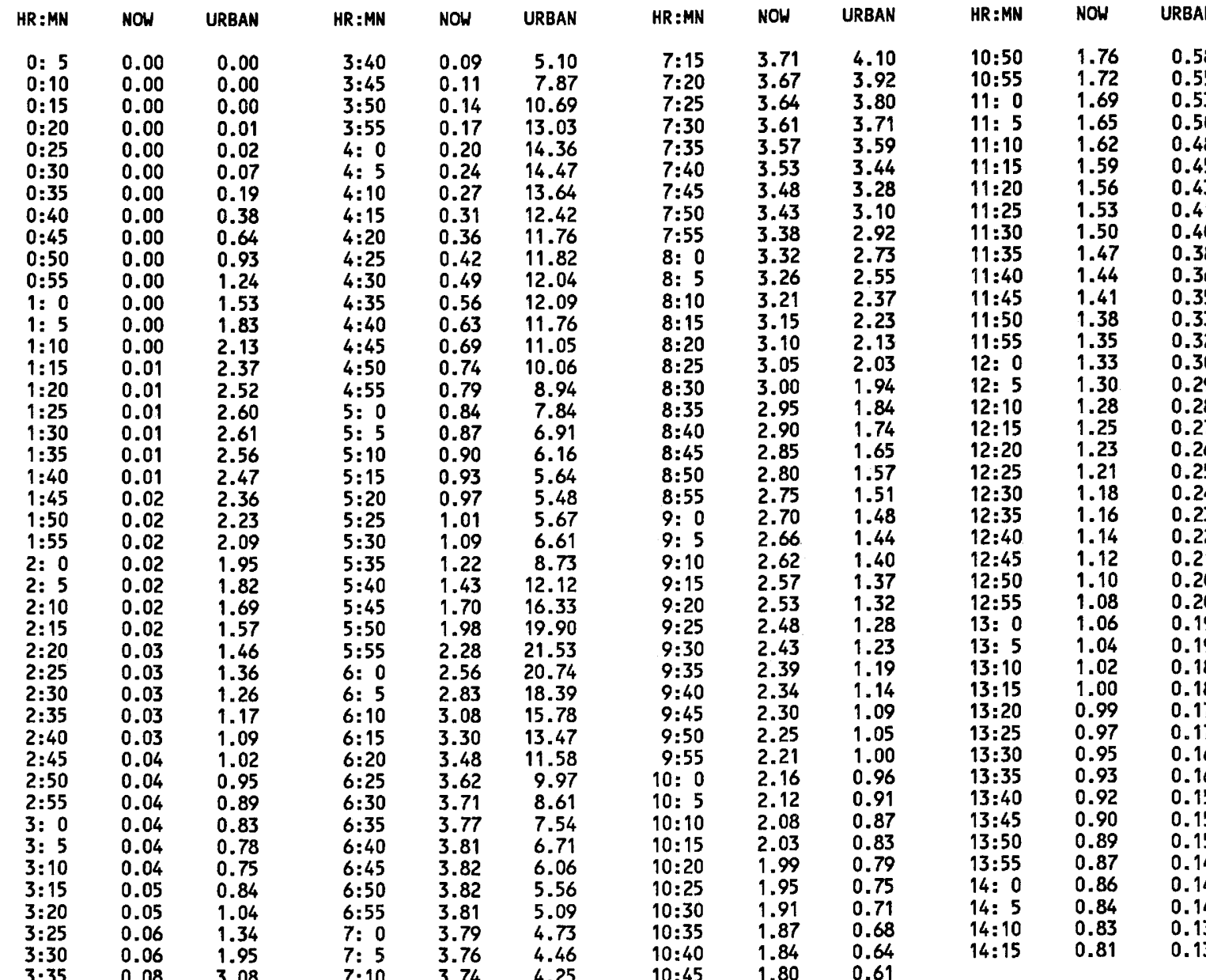

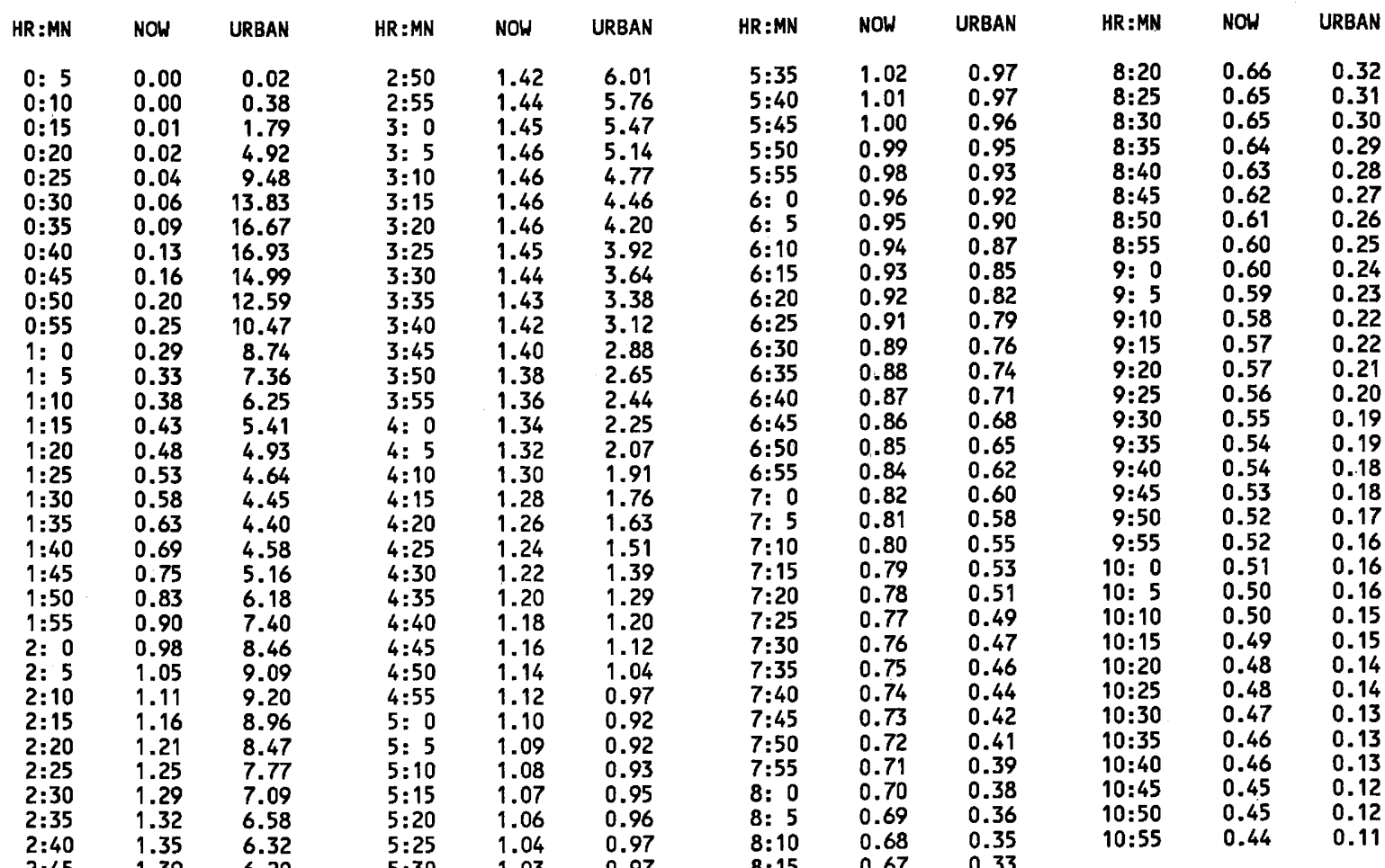



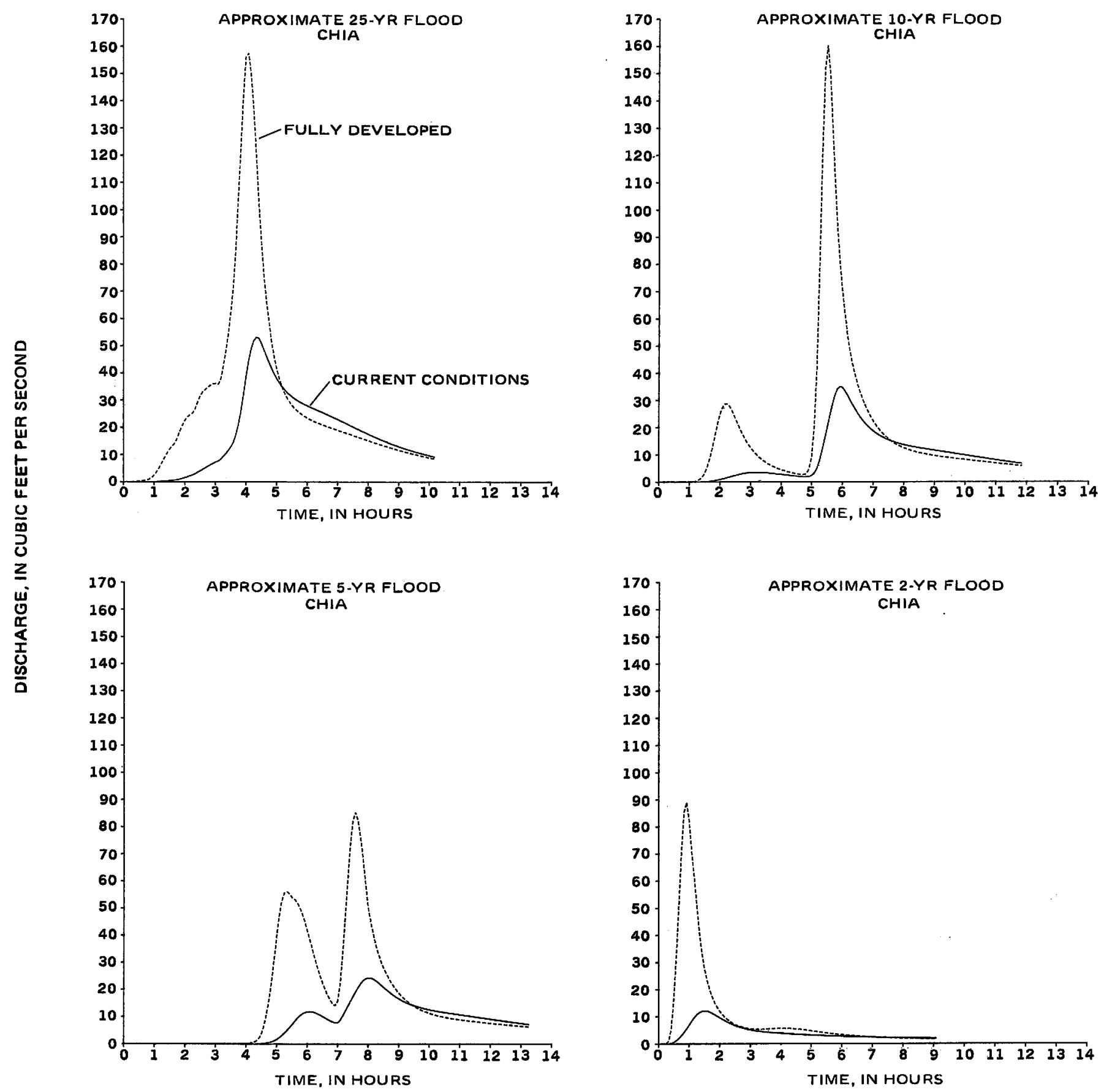

Figure 37. Comparison of approximate 2-, 5-, 10-, and 25-year hydrographs for subbasin CHIA in the Pheasant Branch drainage basin. 
APPROXIMATE 25-YR FLOOD CHIA

\begin{tabular}{|c|c|c|c|c|c|c|c|c|c|c|c|}
\hline HR:MN & NOW & URBAN & HR:MN & NOW & URBAN & HR:MN & NOW & URBAN & $H R: M N$ & NOW & URBAN \\
\hline $\begin{array}{l}0: 5 \\
0: 10 \\
0: 15 \\
0: 20 \\
0: 25 \\
0: 30 \\
0: 35 \\
0: 40 \\
0: 45 \\
0: 50 \\
0: 55 \\
1: 0 \\
1: 5 \\
1: 10 \\
1: 15 \\
1: 20 \\
1: 25 \\
1: 30 \\
1: 35 \\
1: 40 \\
1: 45 \\
1: 50 \\
1: 55 \\
2: 0 \\
2: 5 \\
2: 10 \\
2: 15 \\
2: 20 \\
2: 25 \\
2: 30 \\
2: 35\end{array}$ & $\begin{array}{l}0.00 \\
0.00 \\
0.00 \\
0.00 \\
0.00 \\
0.01 \\
0.01 \\
0.02 \\
0.02 \\
0.03 \\
0.05 \\
0.08 \\
0.12 \\
0.17 \\
0.23 \\
0.30 \\
0.37 \\
0.46 \\
0.54 \\
0.65 \\
0.82 \\
1.06 \\
1.34 \\
1.64 \\
1.96 \\
2.27 \\
2.60 \\
3.03 \\
3.57 \\
4.13 \\
4.70\end{array}$ & $\begin{array}{r}0.00 \\
0.00 \\
0.01 \\
0.05 \\
0.13 \\
0.23 \\
0.35 \\
0.50 \\
0.70 \\
1.04 \\
1.63 \\
2.61 \\
3.86 \\
5.39 \\
7.16 \\
8.92 \\
10.60 \\
12.08 \\
13.26 \\
14.27 \\
16.13 \\
18.62 \\
20.77 \\
22.63 \\
23.92 \\
24.67 \\
25.18 \\
26.72 \\
29.23 \\
31.52 \\
33.07\end{array}$ & $\begin{array}{l}2: 40 \\
2: 45 \\
2: 50 \\
2: 55 \\
3: 0 \\
3: 5 \\
3: 10 \\
3: 15 \\
3: 20 \\
3: 25 \\
3: 30 \\
3: 35 \\
3: 40 \\
3: 45 \\
3: 50 \\
3: 55 \\
4: 0 \\
4: 5 \\
4: 10 \\
4: 15 \\
4: 20 \\
4: 25 \\
4: 30 \\
4: 35 \\
4: 40 \\
4: 45 \\
4: 50 \\
4: 55 \\
5: 0 \\
5: 5 \\
5: 10\end{array}$ & $\begin{array}{r}5.25 \\
5.80 \\
6.35 \\
6.87 \\
7.33 \\
7.73 \\
8.32 \\
9.28 \\
10.38 \\
11.56 \\
12.87 \\
14.43 \\
17.08 \\
21.08 \\
25.94 \\
31.97 \\
38.57 \\
44.39 \\
49.00 \\
52.03 \\
53.24 \\
52.85 \\
51.16 \\
48.75 \\
46.31 \\
44.01 \\
41.84 \\
39.86 \\
38.11 \\
36.57 \\
35.22\end{array}$ & $\begin{array}{r}33.99 \\
34.82 \\
35.55 \\
36.15 \\
36.26 \\
35.87 \\
37.31 \\
41.98 \\
47.74 \\
54.16 \\
61.80 \\
71.07 \\
85.28 \\
104.78 \\
122.93 \\
142.30 \\
156.19 \\
157.50 \\
150.24 \\
137.42 \\
120.94 \\
103.16 \\
89.17 \\
76.28 \\
66.80 \\
59.08 \\
51.72 \\
46.16 \\
41.77 \\
38.22 \\
35.33\end{array}$ & $\begin{array}{l}5: 15 \\
5: 20 \\
5: 25 \\
5: 30 \\
5: 35 \\
5: 40 \\
5: 45 \\
5: 50 \\
5: 55 \\
6: 0 \\
6: 5 \\
6: 10 \\
6: 15 \\
6: 20 \\
6: 25 \\
6: 30 \\
6: 35 \\
6: 40 \\
6: 45 \\
6: 50 \\
6: 55 \\
7: 0 \\
7: 5 \\
7: 10 \\
7: 15 \\
7: 20 \\
7: 25 \\
7: 30 \\
7: 35 \\
7: 40 \\
7: 45\end{array}$ & $\begin{array}{l}34.04 \\
33.01 \\
32.11 \\
31.32 \\
30.61 \\
29.99 \\
29.42 \\
28.91 \\
28.43 \\
27.98 \\
27.55 \\
27.14 \\
26.73 \\
26.33 \\
25.92 \\
25.52 \\
25.11 \\
24.69 \\
24.26 \\
23.83 \\
23.40 \\
22.95 \\
22.50 \\
22.05 \\
21.60 \\
21.14 \\
20.68 \\
20.22 \\
19.77 \\
19.32 \\
18.87\end{array}$ & $\begin{array}{l}32.99 \\
31.08 \\
29.52 \\
28.22 \\
27.12 \\
26.18 \\
25.38 \\
24.67 \\
24.04 \\
23.48 \\
22.98 \\
22.52 \\
22.09 \\
21.69 \\
21.32 \\
20.96 \\
20.62 \\
20.28 \\
19.95 \\
19.63 \\
19.31 \\
18.99 \\
18.67 \\
18.35 \\
18.03 \\
17.71 \\
17.39 \\
17.07 \\
16.75 \\
16.43 \\
16.11\end{array}$ & $\begin{array}{c}7: 50 \\
7: 55 \\
8: 0 \\
8: 5 \\
8: 10 \\
8: 15 \\
8: 20 \\
8: 25 \\
8: 30 \\
8: 35 \\
8: 40 \\
8: 45 \\
8: 50 \\
8: 55 \\
9: 0 \\
9: 5 \\
9: 10 \\
9: 15 \\
9: 20 \\
9: 25 \\
9: 30 \\
9: 35 \\
9: 40 \\
9: 45 \\
9: 50 \\
9: 55 \\
10: 0 \\
10: 5 \\
10: 10\end{array}$ & $\begin{array}{c}18.43 \\
17.99 \\
17.56 \\
17.13 \\
16.71 \\
16.31 \\
15.90 \\
15.51 \\
15.13 \\
14.75 \\
14.38 \\
14.02 \\
13.67 \\
13.33 \\
13.00 \\
12.68 \\
12.37 \\
12.06 \\
11.76 \\
11.48 \\
11.20 \\
10.92 \\
10.66 \\
10.40 \\
10.15 \\
9.91 \\
9.68 \\
9.45 \\
9.23\end{array}$ & $\begin{array}{l}15.80 \\
15.48 \\
15.17 \\
14.85 \\
14.55 \\
14.24 \\
13.94 \\
13.64 \\
13.34 \\
13.06 \\
12.77 \\
12.49 \\
12.22 \\
11.94 \\
11.68 \\
11.42 \\
11.17 \\
10.92 \\
10.67 \\
10.44 \\
10.21 \\
9.98 \\
9.76 \\
9.54 \\
9.33 \\
9.13 \\
8.92 \\
8.73 \\
8.54\end{array}$ \\
\hline
\end{tabular}

\begin{tabular}{|c|c|c|c|c|c|c|c|c|c|c|c|}
\hline HR:MN & NOW & URBAN & HR:MN & NOW & URBAN & $H R: M N$ & NOW & URBAN & HR:MN & NOW & URBAN \\
\hline $\begin{array}{l}0: 5 \\
0: 10 \\
0: 15 \\
0: 20 \\
0: 25 \\
0: 30 \\
0: 35 \\
0: 40 \\
0: 45 \\
0: 50 \\
0: 55 \\
1: 0 \\
1: 5 \\
1: 10 \\
1: 15 \\
1: 20 \\
1: 25 \\
1: 30 \\
1: 35 \\
1: 40 \\
1: 45 \\
1: 50 \\
1: 55 \\
2: 0 \\
2: 55 \\
2: 10 \\
2: 15 \\
2: 20 \\
2: 25 \\
2: 30 \\
2: 35 \\
2: 40 \\
2: 45 \\
2: 50 \\
2: 55 \\
3: 0\end{array}$ & $\begin{array}{l}0.00 \\
0.00 \\
0.00 \\
0.00 \\
0.00 \\
0.00 \\
0.00 \\
0.00 \\
0.00 \\
0.00 \\
0.00 \\
0.00 \\
0.00 \\
0.01 \\
0.02 \\
0.03 \\
0.06 \\
0.10 \\
0.17 \\
0.27 \\
0.39 \\
0.56 \\
0.75 \\
0.97 \\
1.21 \\
1.46 \\
1.73 \\
2.00 \\
2.27 \\
2.53 \\
2.77 \\
2.99 \\
3.18 \\
3.33 \\
3.45 \\
3.54\end{array}$ & $\begin{array}{l}0.00 \\
0.00 \\
0.00 \\
0.00 \\
0.00 \\
0.00 \\
0.00 \\
0.01 \\
0.01 \\
0.01 \\
0.01 \\
0.02 \\
0.06 \\
0.19 \\
0.48 \\
1.00 \\
1.83 \\
3.20 \\
5.50 \\
8.61 \\
12.31 \\
16.67 \\
21.09 \\
24.82 \\
27.44 \\
28.69 \\
28.65 \\
27.44 \\
25.52 \\
23.36 \\
21.19 \\
19.12 \\
17.22 \\
15.50 \\
13.98 \\
12.62\end{array}$ & $\begin{array}{l}3: 5 \\
3: 10 \\
3: 15 \\
3: 20 \\
3: 25 \\
3: 30 \\
3: 35 \\
3: 40 \\
3: 45 \\
3: 50 \\
3: 55 \\
4: 0 \\
4: 5 \\
4: 10 \\
4: 15 \\
4: 20 \\
4: 25 \\
4: 30 \\
4: 35 \\
4: 40 \\
4: 45 \\
4: 50 \\
4: 55 \\
5: 0 \\
5: 5 \\
5: 10 \\
5: 15 \\
5: 20 \\
5: 25 \\
5: 30 \\
5: 35 \\
5: 40 \\
5: 45 \\
5: 50 \\
5: 55 \\
6: 0\end{array}$ & $\begin{array}{l}3.59 \\
3.60 \\
3.59 \\
3.55 \\
3.49 \\
3.41 \\
3.32 \\
3.22 \\
3.12 \\
3.01 \\
2.90 \\
2.78 \\
2.67 \\
2.56 \\
2.46 \\
2.35 \\
2.25 \\
2.16 \\
2.07 \\
1.99 \\
1.93 \\
1.95 \\
2.09 \\
2.48 \\
3.30 \\
4.94 \\
7.69 \\
11.30 \\
15.37 \\
19.70 \\
24.06 \\
28.15 \\
31.66 \\
34.11 \\
35.03 \\
34.61\end{array}$ & $\begin{array}{r}11.42 \\
10.36 \\
9.43 \\
8.60 \\
7.87 \\
7.21 \\
6.63 \\
6.11 \\
5.65 \\
5.23 \\
4.85 \\
4.51 \\
4.20 \\
3.92 \\
3.67 \\
3.43 \\
3.22 \\
3.03 \\
2.85 \\
2.72 \\
2.75 \\
3.25 \\
4.89 \\
9.39 \\
20.15 \\
42.56 \\
79.35 \\
121.18 \\
151.74 \\
160.15 \\
149.62 \\
129.52 \\
109.94 \\
92.60 \\
79.81 \\
69.53\end{array}$ & $\begin{array}{l}6: 5 \\
6: 10 \\
6: 15 \\
6: 20 \\
6: 25 \\
6: 30 \\
6: 35 \\
6: 40 \\
6: 45 \\
6: 50 \\
6: 55 \\
7: 0 \\
7: 5 \\
7: 10 \\
7: 15 \\
7: 20 \\
7: 25 \\
7: 30 \\
7: 35 \\
7: 40 \\
7: 45 \\
7: 50 \\
7: 55 \\
8: 0 \\
8: 5 \\
8: 10 \\
8: 15 \\
8: 20 \\
8: 25 \\
8: 30 \\
8: 35 \\
8: 40 \\
8: 45 \\
8: 50 \\
8: 55 \\
9: 0\end{array}$ & $\begin{array}{l}33.39 \\
31.74 \\
29.99 \\
28.28 \\
26.64 \\
25.11 \\
23.72 \\
22.47 \\
21.36 \\
20.36 \\
19.48 \\
18.69 \\
17.98 \\
17.35 \\
16.79 \\
16.28 \\
15.83 \\
15.42 \\
15.05 \\
14.71 \\
14.41 \\
14.13 \\
13.87 \\
13.63 \\
13.41 \\
13.21 \\
13.01 \\
12.83 \\
12.66 \\
12.49 \\
12.33 \\
12.17 \\
12.02 \\
11.87 \\
11.72 \\
11.58\end{array}$ & $\begin{array}{l}60.99 \\
53.45 \\
47.57 \\
42.89 \\
38.91 \\
35.54 \\
32.64 \\
30.09 \\
27.83 \\
25.82 \\
24.01 \\
22.40 \\
20.96 \\
19.67 \\
18.53 \\
17.51 \\
16.60 \\
15.80 \\
15.08 \\
14.44 \\
13.86 \\
13.35 \\
12.89 \\
12.48 \\
12.11 \\
11.77 \\
11.47 \\
11.19 \\
10.94 \\
10.71 \\
10.49 \\
10.30 \\
10.11 \\
9.94 \\
9.78 \\
9.63\end{array}$ & $\begin{array}{c}9: 5 \\
9: 10 \\
9: 15 \\
9: 20 \\
9: 25 \\
9: 30 \\
9: 35 \\
9: 40 \\
9: 45 \\
9: 50 \\
9: 55 \\
10: 0 \\
10: 5 \\
10: 10 \\
10: 15 \\
10: 20 \\
10: 25 \\
10: 30 \\
10: 35 \\
10: 40 \\
10: 45 \\
10: 50 \\
10: 55 \\
11: 0 \\
11: 5 \\
11: 10 \\
11: 15 \\
11: 20 \\
11: 25 \\
11: 30 \\
11: 35 \\
11: 40 \\
11: 45 \\
11: 50\end{array}$ & $\begin{array}{l}11.43 \\
11.29 \\
11.14 \\
11.00 \\
10.85 \\
10.71 \\
10.56 \\
10.42 \\
10.27 \\
10.12 \\
9.97 \\
9.83 \\
9.68 \\
9.53 \\
9.38 \\
9.24 \\
9.09 \\
8.94 \\
8.80 \\
8.65 \\
8.51 \\
8.36 \\
8.22 \\
8.08 \\
7.94 \\
7.81 \\
7.67 \\
7.54 \\
7.41 \\
7.28 \\
7.15 \\
7.02 \\
6.90 \\
6.77\end{array}$ & $\begin{array}{l}9.49 \\
9.35 \\
9.22 \\
9.09 \\
8.97 \\
8.85 \\
8.73 \\
8.62 \\
8.50 \\
8.39 \\
8.28 \\
8.18 \\
8.07 \\
7.96 \\
7.86 \\
7.75 \\
7.65 \\
7.54 \\
7.44 \\
7.33 \\
7.23 \\
7.13 \\
7.02 \\
6.92 \\
6.82 \\
6.72 \\
6.62 \\
6.52 \\
6.43 \\
6.33 \\
6.23 \\
6.14 \\
6.04 \\
5.95\end{array}$ \\
\hline
\end{tabular}


APPROXIMATE 5-YR FLOOD CHIA

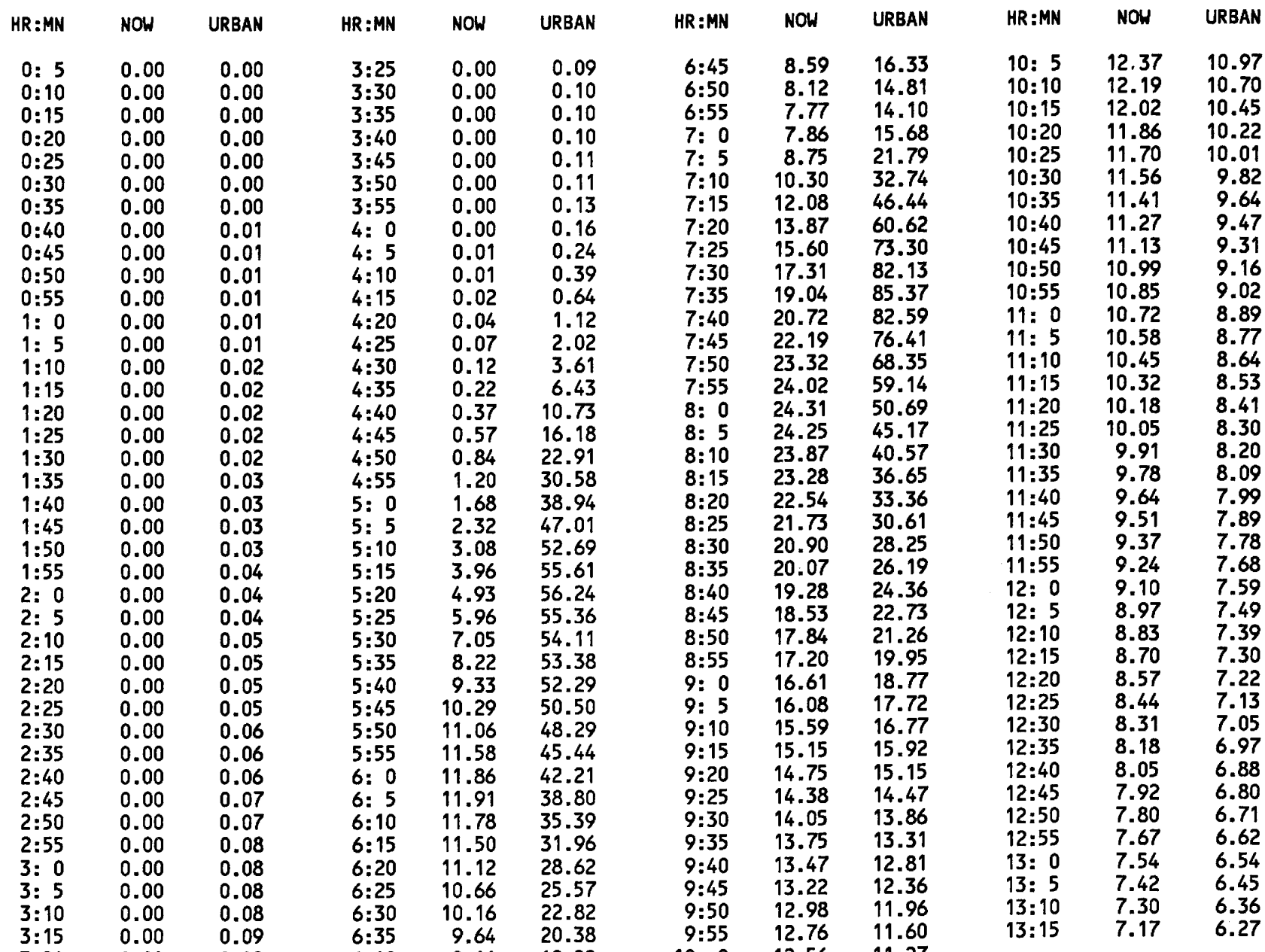

APPROXIMATE 2-YR FLOOD CHIA

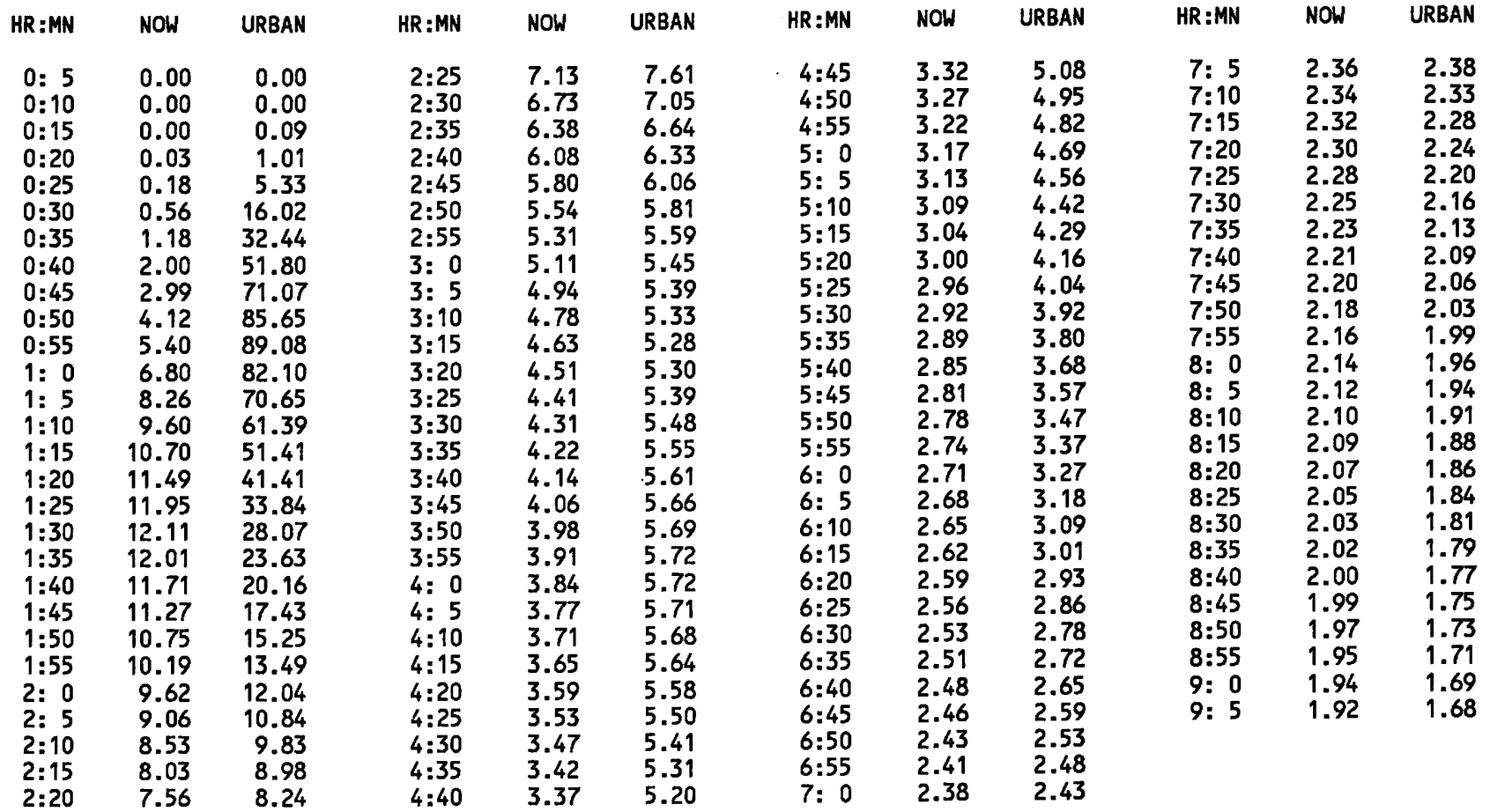



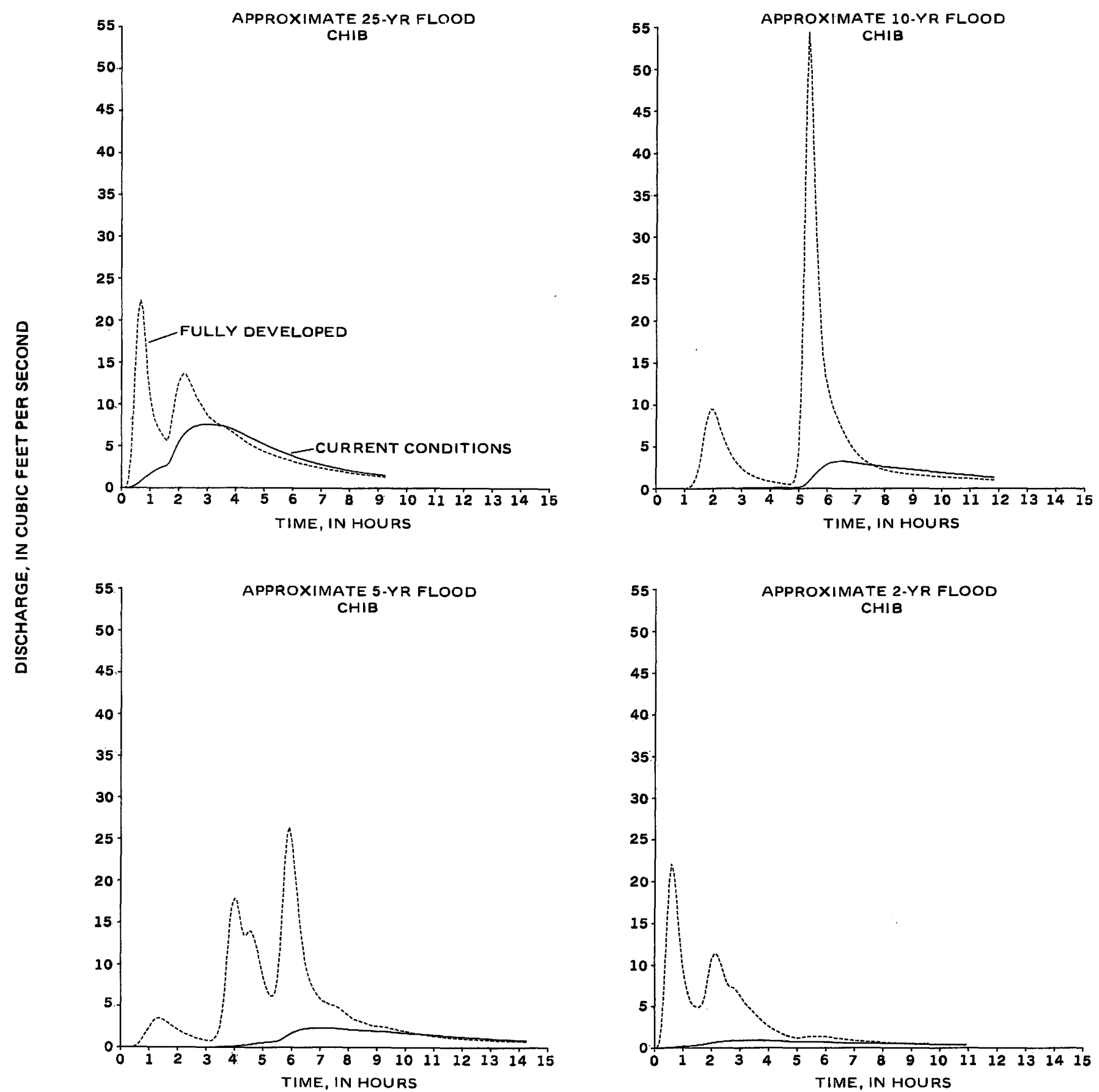

Figure 38. Comparison of approximate 2-, 5-, 10-, and 25-year hydrographs for subbasin CHIB in the Pheasant Branch drainage basin. 
APPROXIMATE 25-YR FLOOD CHIB

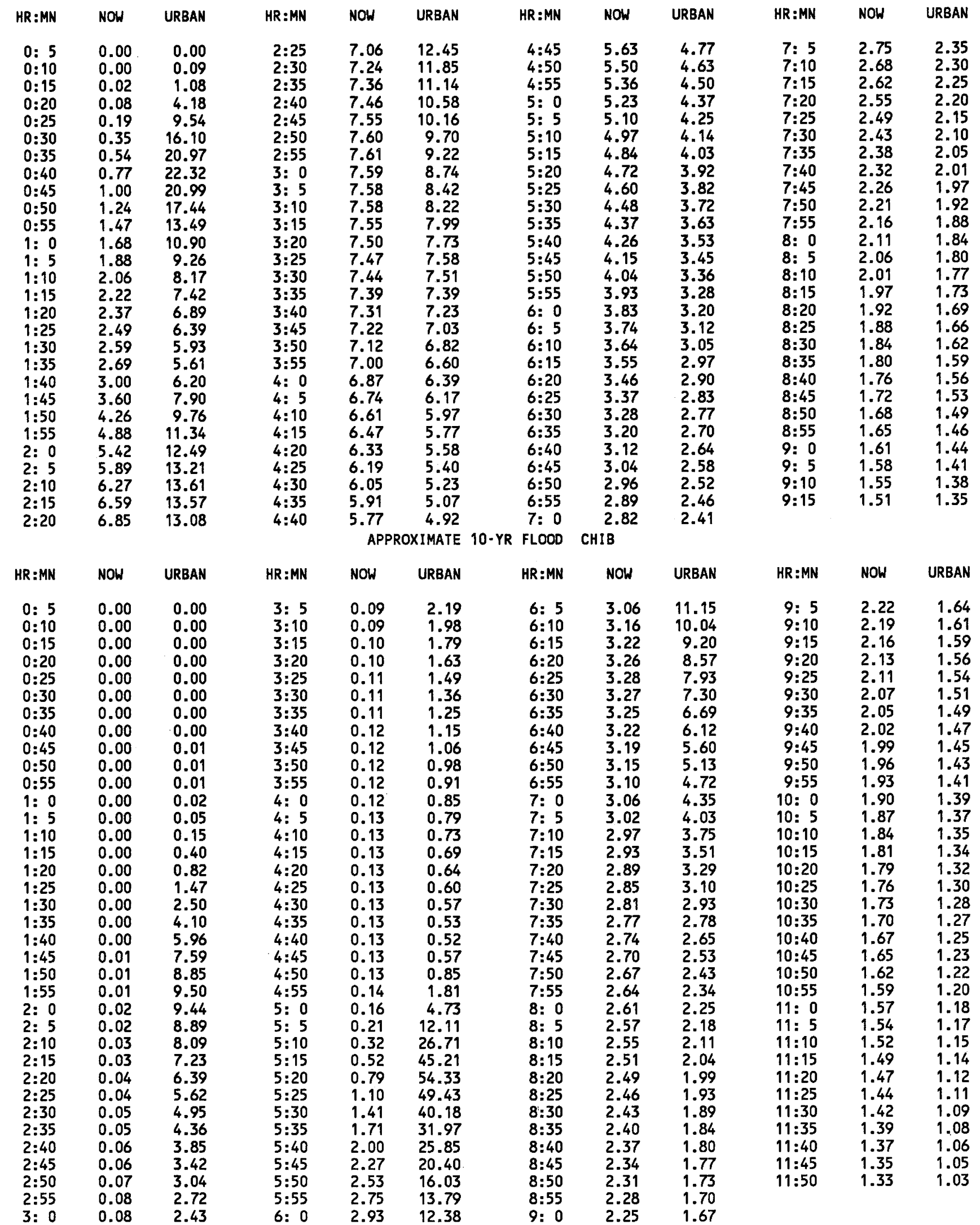


APPROXIMATE 5-YR FLOOD CHIB

\begin{tabular}{|c|c|c|c|c|c|c|c|c|c|c|c|}
\hline HR:MN & NOW & URBAN & $H R: M N$ & NOW & URBAN & $H R: M N$ & NOW & URBAN & HR:MN & NOW & URBAN \\
\hline $\begin{array}{l}0: 5 \\
0: 10 \\
0: 15 \\
0: 20 \\
0: 25 \\
0: 30 \\
0: 35 \\
0: 40 \\
0: 45 \\
0: 50 \\
0: 55 \\
1: 0 \\
1: 5 \\
1: 10 \\
1: 15 \\
1: 20 \\
1: 25 \\
1: 30 \\
1: 35 \\
1: 40 \\
1: 45 \\
1: 50 \\
1: 55 \\
2: 0 \\
2: 5 \\
2: 10 \\
2: 15 \\
2: 20 \\
2: 25 \\
2: 30 \\
2: 35 \\
2: 40 \\
2: 45 \\
2: 50 \\
2: 55 \\
3: 0 \\
3: 5 \\
3: 10 \\
3: 15 \\
3: 20 \\
3: 25 \\
3: 30\end{array}$ & $\begin{array}{l}0.00 \\
0.00 \\
0.00 \\
0.00 \\
0.00 \\
0.00 \\
0.00 \\
0.00 \\
0.00 \\
0.00 \\
0.00 \\
0.00 \\
0.00 \\
0.00 \\
0.00 \\
0.00 \\
0.00 \\
0.01 \\
0.01 \\
0.01 \\
0.01 \\
0.01 \\
0.01 \\
0.01 \\
0.01 \\
0.02 \\
0.02 \\
0.02 \\
0.02 \\
0.02 \\
0.02 \\
0.02 \\
0.02 \\
0.02 \\
0.03 \\
0.03 \\
0.03 \\
0.03 \\
0.03 \\
0.04 \\
0.04 \\
0.05\end{array}$ & $\begin{array}{l}0.00 \\
0.00 \\
0.00 \\
0.01 \\
0.03 \\
0.11 \\
0.30 \\
0.60 \\
1.01 \\
1.48 \\
1.96 \\
2.40 \\
2.83 \\
3.21 \\
3.43 \\
3.50 \\
3.45 \\
3.32 \\
3.14 \\
2.94 \\
2.73 \\
2.52 \\
2.32 \\
2.14 \\
1.97 \\
1.81 \\
1.66 \\
1.54 \\
1.42 \\
1.31 \\
1.21 \\
1.12 \\
1.04 \\
0.97 \\
0.90 \\
0.84 \\
0.79 \\
0.76 \\
0.90 \\
1.21 \\
1.65 \\
2.54\end{array}$ & $\begin{array}{l}3: 40 \\
3: 45 \\
3: 50 \\
3: 55 \\
4: 0 \\
4: 5 \\
4: 10 \\
4: 15 \\
4: 20 \\
4: 25 \\
4: 30 \\
4: 35 \\
4: 40 \\
4: 45 \\
4: 50 \\
4: 55 \\
5: 0 \\
5: 5 \\
5: 10 \\
5: 15 \\
5: 20 \\
5: 25 \\
5: 30 \\
5: 35 \\
5: 40 \\
5: 45 \\
5: 50 \\
5: 55 \\
6: 0 \\
6: 5 \\
6: 10 \\
6: 15 \\
6: 20 \\
6: 25 \\
6: 30 \\
6: 35 \\
6: 40 \\
6: 45 \\
6: 50 \\
6: 55 \\
7: 0 \\
7: 5\end{array}$ & $\begin{array}{l}0.07 \\
0.08 \\
0.10 \\
0.12 \\
0.14 \\
0.17 \\
0.19 \\
0.22 \\
0.26 \\
0.30 \\
0.35 \\
0.40 \\
0.44 \\
0.49 \\
0.53 \\
0.56 \\
0.59 \\
0.62 \\
0.64 \\
0.66 \\
0.69 \\
0.72 \\
0.77 \\
0.87 \\
1.02 \\
1.19 \\
1.38 \\
1.56 \\
1.72 \\
1.87 \\
1.99 \\
2.10 \\
2.18 \\
2.24 \\
2.28 \\
2.32 \\
2.34 \\
2.35 \\
2.36 \\
2.36 \\
2.35 \\
2.34\end{array}$ & $\begin{array}{r}7.21 \\
11.26 \\
14.87 \\
17.13 \\
17.90 \\
17.57 \\
16.26 \\
14.43 \\
13.47 \\
13.63 \\
14.02 \\
14.00 \\
13.38 \\
12.39 \\
11.22 \\
9.91 \\
8.60 \\
7.54 \\
6.71 \\
6.20 \\
6.18 \\
6.60 \\
8.04 \\
11.10 \\
15.91 \\
21.47 \\
25.37 \\
26.38 \\
24.89 \\
22.19 \\
19.30 \\
16.30 \\
13.63 \\
11.56 \\
9.89 \\
8.68 \\
7.80 \\
7.16 \\
6.69 \\
6.22 \\
5.88 \\
5.63\end{array}$ & $\begin{array}{c}7: 15 \\
7: 20 \\
7: 25 \\
7: 30 \\
7: 35 \\
7: 40 \\
7: 45 \\
7: 50 \\
7: 55 \\
8: 0 \\
8: 5 \\
8: 10 \\
8: 15 \\
8: 20 \\
8: 25 \\
8: 30 \\
8: 35 \\
8: 40 \\
8: 45 \\
8: 50 \\
8: 55 \\
9: 0 \\
9: 5 \\
9: 10 \\
9: 15 \\
9: 20 \\
9: 25 \\
9: 30 \\
9: 35 \\
9: 40 \\
9: 45 \\
9: 50 \\
9: 55 \\
10: 0 \\
10: 55 \\
10: 10 \\
10: 15 \\
10: 20 \\
10: 25 \\
10: 30 \\
10: 35 \\
10: 40\end{array}$ & $\begin{array}{l}2.33 \\
2.32 \\
2.31 \\
2.30 \\
2.28 \\
2.27 \\
2.25 \\
2.23 \\
2.21 \\
2.18 \\
2.16 \\
2.14 \\
2.12 \\
2.10 \\
2.08 \\
2.07 \\
2.05 \\
2.03 \\
2.01 \\
1.99 \\
1.98 \\
1.96 \\
1.95 \\
1.93 \\
1.92 \\
1.90 \\
1.88 \\
1.87 \\
1.85 \\
1.83 \\
1.81 \\
1.79 \\
1.77 \\
1.74 \\
1.72 \\
1.70 \\
1.68 \\
1.66 \\
1.64 \\
1.62 \\
1.60 \\
1.58\end{array}$ & $\begin{array}{l}5.36 \\
5.20 \\
5.10 \\
5.05 \\
4.93 \\
4.77 \\
4.57 \\
4.35 \\
4.12 \\
3.89 \\
3.66 \\
3.45 \\
3.31 \\
3.24 \\
3.15 \\
3.05 \\
2.95 \\
2.84 \\
2.74 \\
2.63 \\
2.57 \\
2.57 \\
2.55 \\
2.52 \\
2.48 \\
2.43 \\
2.38 \\
2.32 \\
2.26 \\
2.20 \\
2.13 \\
2.07 \\
2.01 \\
1.95 \\
1.89 \\
1.83 \\
1.78 \\
1.73 \\
1.68 \\
1.63 \\
1.58 \\
1.54\end{array}$ & $\begin{array}{l}10: 50 \\
10: 55 \\
11: 0 \\
11: 5 \\
11: 10 \\
11: 15 \\
11: 20 \\
11: 25 \\
11: 30 \\
11: 35 \\
11: 40 \\
11: 45 \\
11: 50 \\
11: 55 \\
12: 0 \\
12: 5 \\
12: 10 \\
12: 15 \\
12: 20 \\
12: 25 \\
12: 30 \\
12: 35 \\
12: 40 \\
12: 45 \\
12: 50 \\
12: 55 \\
13: 0 \\
13: 5 \\
13: 10 \\
13: 15 \\
13: 20 \\
13: 25 \\
13: 30 \\
13: 35 \\
13: 40 \\
13: 45 \\
13: 50 \\
13: 55 \\
14: 0 \\
14: 5 \\
14: 10 \\
14: 15\end{array}$ & $\begin{array}{l}1.53 \\
1.51 \\
1.49 \\
1.47 \\
1.45 \\
1.43 \\
1.41 \\
1.39 \\
1.37 \\
1.35 \\
1.33 \\
1.31 \\
1.29 \\
1.27 \\
1.25 \\
1.23 \\
1.22 \\
1.20 \\
1.18 \\
1.16 \\
1.15 \\
1.13 \\
1.11 \\
1.10 \\
1.08 \\
1.06 \\
1.05 \\
1.03 \\
1.02 \\
1.00 \\
0.99 \\
0.97 \\
0.96 \\
0.94 \\
0.93 \\
0.92 \\
0.90 \\
0.89 \\
0.88 \\
0.86 \\
0.85 \\
0.84\end{array}$ & $\begin{array}{l}1.46 \\
1.42 \\
1.39 \\
1.36 \\
1.32 \\
1.29 \\
1.26 \\
1.24 \\
1.21 \\
1.18 \\
1.16 \\
1.14 \\
1.12 \\
1.09 \\
1.07 \\
1.05 \\
1.04 \\
1.02 \\
1.00 \\
0.98 \\
0.97 \\
0.95 \\
0.93 \\
0.92 \\
0.90 \\
0.89 \\
0.88 \\
0.87 \\
0.86 \\
0.85 \\
0.84 \\
0.84 \\
0.83 \\
0.81 \\
0.80 \\
0.79 \\
0.78 \\
0.77 \\
0.76 \\
0.75 \\
0.74 \\
0.73\end{array}$ \\
\hline
\end{tabular}

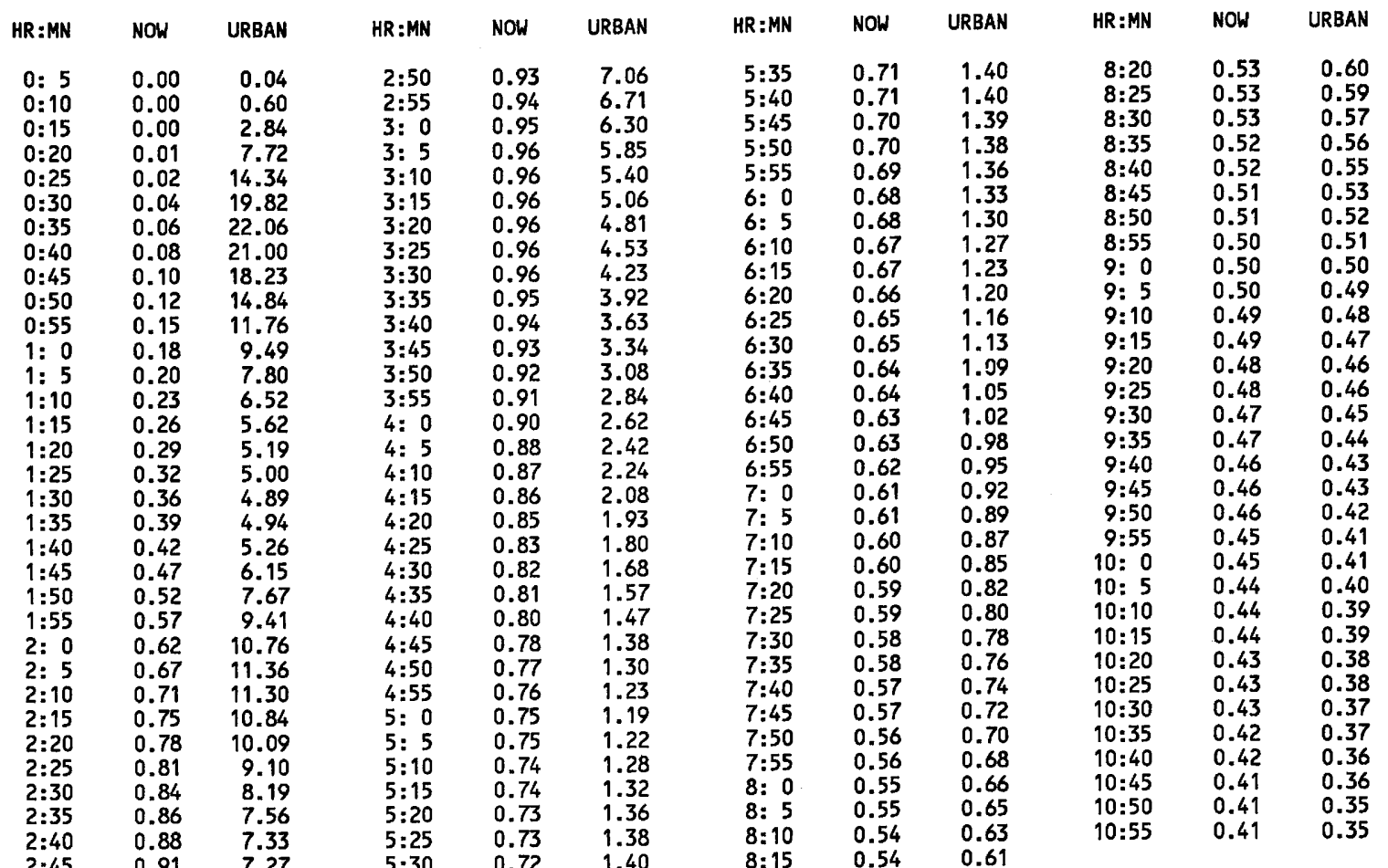







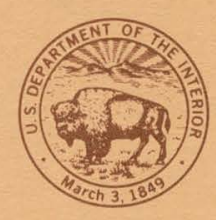

